BNWL-354

$41-$

\title{
ENGINEERING DEVELOPMENT OF THE SALT CYCLE PROCESS
}

RESEARCH

4.1.

DEVELOPMENT

BEPORT
G. JANSEN, JR.

L. K. MUDGE

P. W. SMITH

DECEMBER, 1966

\section{BAtTELLE=NORTHWEST-}

BATTELLE MEMORIAL INSTITUTE / PACIFIC NORTHWEST LABORATORY 


\section{LEGAL NOTICE}

This report was prepored as an account of Government sponsored work. Neither the United States, nor the Commission, nor any person acting on behalf of the Commission;

A. Makes any warronty or representation, expressed or implied, with respect to the accuracy, com. pleteness, or usefulness of the informotion contained in this report, or that the use of any information, opparatus, method, or process disclosed in this report may not infringe privately owned rights; or

B. Assumes any liabilities with respect to the use of, or for damages resulting from the use of any information, apparatus, method, or process disclosed in this report.

As used in the above, "person acting on behalf of the Commission" includes any employee or contractor of the Commission, or employee of such contractor, to the extent that such employee or contractor of the Commission, or employee of such contractor prepares, disseminates, or provides access to. any information pursuant to his employment or contract with the Commission, or his employment with such contractor

\section{PACIFIC NORTHWEST LABORATORY \\ RICHLAND, WASHINGTON \\ operated by \\ BATTELLE MEMORIAL INSTITUTE}

for the

UNITED STATES ATOMIC ENERGY COMMISSION UNDER CONTRACT AT(45-1)-1830 


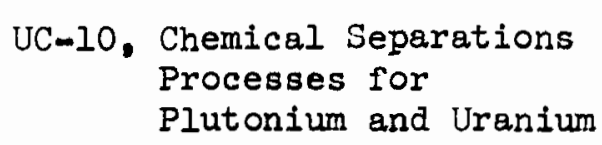

ENGINEERING DEVELOPMENT

OF THE SALT CYCLE PROCESS

By

G. Jansen, Jr.

L. K. Mudge

P. W. Smith*

Chemical Development Section

Chemistry Department

December, 1966

WRET ONRESTRICTED

DISTRIBUT:ON WAOE

MAR3 '67

PACIFIC NORTHWEST ILABORATORY

RICHIAND, WASHINGTON

${ }^{*}$ P. W. Smith transferred from the Hanford Laboratories to the Chemical Processing Department of the General Electric Company and is now an employee of Isochem Inc. 
Printed in USA。 Price \$5.00。 Available from the Clearinghouse for Federal Scientific and Technical Information, National Bureau of Standards, U. S. Department of Commerce, Springfield, Virginia 22151 
ENGINEERING DEVELOPMENT

OF THE SALT CYCLE PROCESS

\section{ABSTRACT}

The pilot plant production of electrolytic uranium dioxide and the development of equipment to be used in remote processing of irradiated mixed $\mathrm{PuO}_{2}-\mathrm{UO}_{2}$ fuels are presented. The process steps are fuel decladding, oxidation of $\mathrm{UO}_{2}$ to $\mathrm{U}_{3} \mathrm{O}_{8}$, dissolution in molten salts with chlorine and hydrogen chloride gases, electrolytic deposition of oxides, product purification, crushing and sizing, and off-gas treatment. 


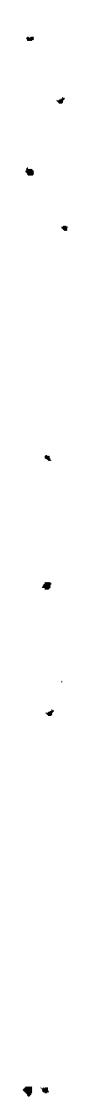

. 


\section{TABLE OF CONTTNTS}

LIST OF FIGURES

LIST OF TABLES .

INTRODUCTION

SURMARY

DECLADDING

Vibrational Decladding

Oxidative Decladding

Gas-Phase Chlorination of Zircaloy .

Decladding by Sparging Molten Salts

Metal Replacement Reaction

Tffect of Jecladding on Flectrolytic $\mathrm{UO}_{2}$ Deposition

viii

xi

1

5

7

Chlorination of Stainless Steel

OXIDATION .

SALT SYSTEM PROPERTIES

Phase Diagrams .

Densities of Molten Salts

Electrical Conductivity of uo

Decomposition Potentials of $\mathrm{UO}_{2} \mathrm{Cl}_{2}$ and Salt Solvents

Dissolution and Drying

Electrolysis

Dual Vessel Experiments

Evaluation of Flectrolytic $\mathrm{UO}_{2}$ Product . . EQUIPIENT FOR PILOT PLANT OPERATIONS

Electrolytic Cell

Instrumentation

Reference Electrode Control System. Dryness Test Apparatus

Crucible Breakage Alarm

LEAD CHLORIDE-POTASSIUM CHLORIDE PILOT PLANT OPERATIONS

Dissolution

Drying 


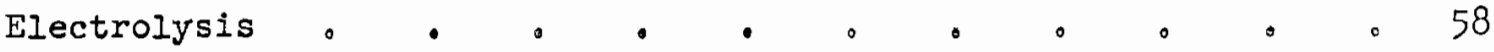

Product Evaluation 。 . • . • . . . . 64

LITHIUM CHLORIDE-POTASSIUM CHLORIDE PILOT PLANT OPERATIONS • • . 66

Dissolution and Drying in the 80 Liter Salt Bath 。 . 。 66

Electrolysis and Product Evaluation from 80 Liter

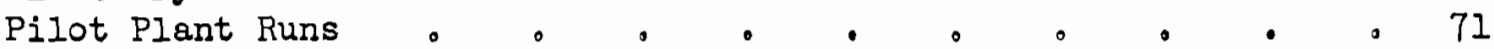

Effect of Impurities on Deposit Crystal Structure . $\quad . \quad$ - 75

Hot Cell Prototype Operations 。

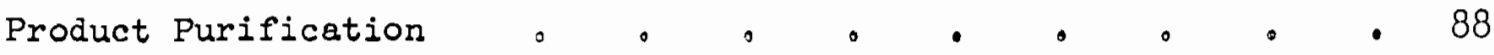

ELECTRODE EVALUATION

Anodes 0.0 .0 .01

Metalic Cathodes 。 0.0092

Graphite Cathodes 。 . . . . 0.094

CONTAINER EVALUATION

Metallic Crucible Materials o o o 。 0.07

Fused Silica Crucibles 。 0.097

Fused Silica Vessel Failures o 0 - 0.00

Other Nonmetallic Materials 。 0.0101

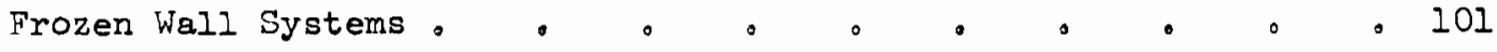

Pyrolytic-Graphite-Coated Crucibles o 。 $\circ \cdot 0103$

CODEPOSITION AND PARTITION

Cerium Stand-In for Plutonium 。 0.00105

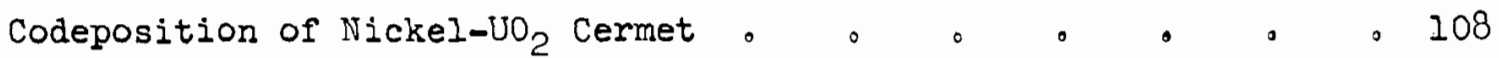

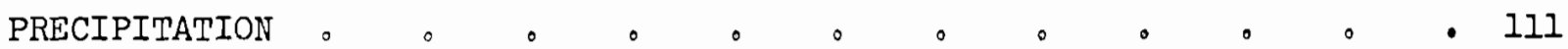

Freeze-Valve Technique $0 \circ 0,0$ - 0 - 01

Thorium Stand-In for Plutonium 0 - 0.0111

Cerium Stand-In for Plutonium 。 0.00112

CRUSHING AND SIEVING 0.000 .00114

Wet Crushing and Sieving System o 0.0115

Iler Disc Pulverizer 0.00117

Press Crushing with Notched Blades 。 - 0.00123

Parallel Plate Crushing 。 0.00127

Multipurpose Fines Production, Sieving, and

Blending Equipment $0.0,0.0131$

Ball Milling $\circ \circ \circ \circ \circ \circ . \circ 139$ 


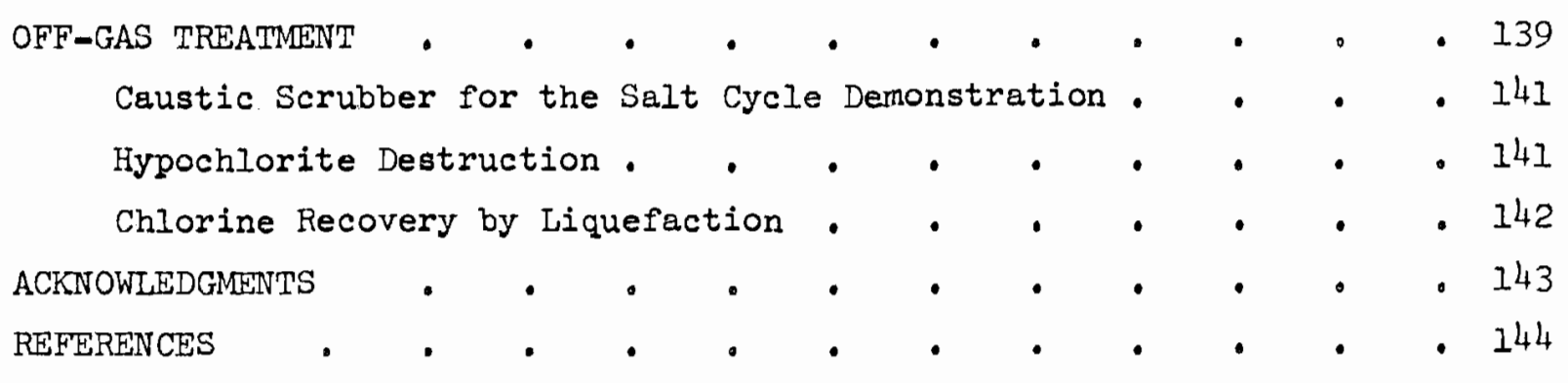




\section{LIST OF FIGURES}

11 Electrical Conductivity of Electrolytic $\mathrm{UO}_{2}$ Deposited from Equimolar $\mathrm{NaCl}-\mathrm{KCl}$ at $700{ }^{\circ} \mathrm{C} .{ }^{\circ} \cdot{ }^{\circ} .032$

Pilot Plant Equipment for Production of Electrolytic $\mathrm{UO}_{2}$ in Equimolar $\mathrm{NaCl}-\mathrm{KCl}$.. .036 Electrolysis with Continuous Recirculation . . . 41 $\mathrm{UO}_{2}$ Deposit from $\mathrm{NaCl}-\mathrm{KCl}$ Salt Bath

Eighty Liter Pilot Plant Salt Bath for $\mathrm{PbCl}_{2}-\mathrm{KCl}$ System 0.048 
$\mathrm{UO}_{2}$ Deposits on Hastelloy $\mathrm{D}$ Cathodes from 80 Liter LiCl-KCl Salt Baths

$\mathrm{UO}_{2}$ Deposits on Graphite Cathodes from 80 Liter

LiCl-KCl Salt Baths

Reference Potential Variation in Constant Current

Hot Cell Prototype Equipment Dissolution of $\mathrm{U}_{3} \mathrm{O}_{8}$ in $2.5 \mathrm{LiCl}-1 \mathrm{KCl}$. . . . 82 Dissolution of $\mathrm{U}_{3} \mathrm{O}_{8}$ in $2.5 \mathrm{LiCl}-1 \mathrm{KCl}$ with a Gas Lift. 83 Voltage-Current Relationships in the Hot Cell Prototype Equipment . . . . . . . 84

Crystal Characteristics of Hot Cell Prototype Electrolysis Product

Typical Deposit from the Hot Cell Prototype

Electrolysis Product . . . . . . 87

Platinum Electrode Sheathed with Quartz, Run CT-4 . 92

Effect of Corrosion of Nickel Electrode on

$\mathrm{UO}_{2}$ Deposit 。 $. \quad . \quad$ • • • 93

Pyrolytic Graphite Coating on a Pile Graphite

Cathode.

Comparison of Stripping of $\mathrm{JO}_{2}$ from Pyrolytic-GraphiteCoated Electrode with Stripping of a Pile Graphite Electrode

Temperature Profiles in the Salt Bath Mockup for the Salt Cycle Demonstration

Induction-Heated System After Several Days Operation with a Broken Quartz Crucible

Cross Section of a Graphite Susceptor with a Frozen Wall After Several Days Operation . . . 102

43 Pyrolytic Graphite Crucibles After Testing at $600^{\circ} \mathrm{C}$ for 13 Days . . . . . . . 104

44 Codeposit with 50\% Oxygen - 50\% Chlorine Sparge • • 107

45 Deposit from a High Temperature Partition . . . 109

46 Codeposits with Intermittent Electrolyses . . . 110

47 Wet Crushing and Sieving System . . . . . 116 
Variation of Gap Between Discs - Product from Iler Disc Pulverizer . 0 。 . . .

Effect of Speed on Crushing with Iler Disc

51 Effect of Speed on Single Pass Crushing of Electrolytic $\mathrm{JO}_{2}$ with Iler Disc Pulverizer . . . .

Effect of lioisture on Crushing and Screening Operations with Iler Disc Pulverizer . . . . 122

Integrated Crushing of Electrolytic $\mathrm{UO}_{2}$ with Iler Disc Pulverizer to Produce Large Size Fraction • . 124

Product from $\mathrm{UO}_{2}$ Dicer Operation at 500 psi Terminal

Effect of Pressure on Dicing of Electrolytic $\mathrm{UO}_{2}$.

Production of Large and Intermediate Size Particles by Integrated Dicing Operations, Comparison of Size Distribution with Iler Disc Pulverizer Product

Single-Pass Crushing with Parallel Plates - Effect of Step Size and Size Reduction.

Integrated Parallel Plate Crushing of Electrolytic $\mathrm{UO}_{2}$ - Comparison of 0.222 " Step with 0.156" Step in Production of $-4+10$ Mesh Particles

Effect of Pressure on Production of Intermediate Fraction $\mathrm{UO}_{2}$ Particles . . . . . . 134 
Table No.

I

II

III

IV

V

VI

VII

VIII

IX

X

XI

XII

XIII

XIV

XV

XVI

XVII

XVIII

XIX

$\mathrm{XX}$
Title

Page No.

Gas Phase Decladding Studies . . . . . . 14

Decladding by Gas Sparge in Molten Salts . . . 17

Decladding with Metal Replacement Reaction . . • 19

Effect of Decladding on Electrolytic $\mathrm{UO}_{2}$

Deposition

Decladding of Stainless Steel . • . . . 22

Oxidation of $\mathrm{UO}_{2}$ in Prototype Oxidation Equipment . 25

Pilot Plant Electrolyses . . . . . 38

Chemical Analyses of Electrolytic $\mathrm{UO}_{2}$ Produced

from the $\mathrm{NaCl}-\mathrm{KCl}$ System

Pilot Plant Electrolyses in the Lead Chloride-

Potassium Chloride System, Twenty Liter.Salt.Bath. . 55

Pilot Plant Electrolyses in the Lead Chloride-

Potassium Chloride System, Eighty Liter Salt Bath.

63

Effect of Hydrogen Treatment for 10 Hours at $1000{ }^{\circ} \mathrm{C}$

on Salt Content of Electrodeposited $\mathrm{UO}_{2}$.

65

Pilot Plant Electrolyses in the Lithium Chloride-

Potassium Chloride System . . . . . . 67

Effect of Impurities on Electrolyses in Tithium

Chloride-Potassium Chloride 。 . . . . . 77

Hot Cell Prototype Electrolyses . • . • • 80

Chemical Analysis of Composite Product from LiCl-

$\mathrm{KCl}$ Pilot Plant Operations . . • . . 89

Chloride Analyses in Aqueous Washing Studies . $\quad 90$

Corrosion of Metals in the Salt Cycle Environment. $\quad 99$

Cerium Stand-In for Plutonium in $\mathrm{UO}_{2}$ Depositions. . 106

Fines Production by High-Speed Impaction • . . 137

Sieving Studies in Multipurpose Equipment . . . 138 
$\cdot$
$\cdot$
$\cdot$
$\cdot$
. 


\section{ENGINEERING DEVELOPMENT}

OF THE SALT CYCLE PROCESS

\section{INTRODUCTION}

The Salt Cycle process was developed at Hanford as part of the Plutonium Recycle Program to reprocess $\mathrm{UO}_{2}-\mathrm{PuO}_{2}$ mixed oxide fuels for recycle to thermal reactors. In the recycle scheme short-cooled, irradiated fuel is reprocessed with a minimum number of remote manipulations. The central step in the process is the electrolytic deposition of crystalline, reactor-grade $\mathrm{UO}_{2}-\mathrm{PuO}_{2}$ solid solutions from molten chloride salts. The engineering development of the unit operations of the Salt Cycle process; such as decladding, dissolution, drying, off-gas treatment, electrolysis, and crushing, sizing and purification of the product; is described in detail here. Equipment for remote operation of the process was designed and tested, and several hundred pounds of electrolytic $\mathrm{UO}_{2}$ that met reactor specifications were produced for evaluation as nuclear fuel.

One close-coupled plutonium recycle system that was considered for application of the Salt Cycle process is shown in Figure 1. The system is based on a zoned reactor which is fueled with unirradiated, slightly enriched $\mathrm{UO}_{2}$ fuel elements and recycle $\mathrm{UO}_{2}-\mathrm{PuO}_{2}$ fuel elements containing lower enrichment uranium. A zoned reactor reduces fuel fabrication costs by minimizing the number of remotely fabricated recycle fuel elements. For this system the process should have the capability of (I) recovering the plutonium from the depleted recycle uranium in the irradiated $\mathrm{UO}_{2}-\mathrm{PuO}_{2}$ fuel elements, (2) combining on a molecular scale the recovered plutonium with the plutonium and a portion of the uranium from the irradiated $\mathrm{UO}_{2}$ fuel elements, and (3) producing a $\mathrm{UO}_{2}-\mathrm{PuO}_{2}$ mixture which has physical properties suitable for refabrication and is relatively free of neutron poisoning fission products.

Because the Salt Cycle process has been specifically developed for reprocessing irradiated, short-cooled $\mathrm{UO}_{2}-\mathrm{PuO}_{2}$ mixed oxide nuclear fuels, an economic study of the relative merits of close-coupled, remote processing and centralplant processing has been made by $R$. W. McKee. (1) The first stage in the 


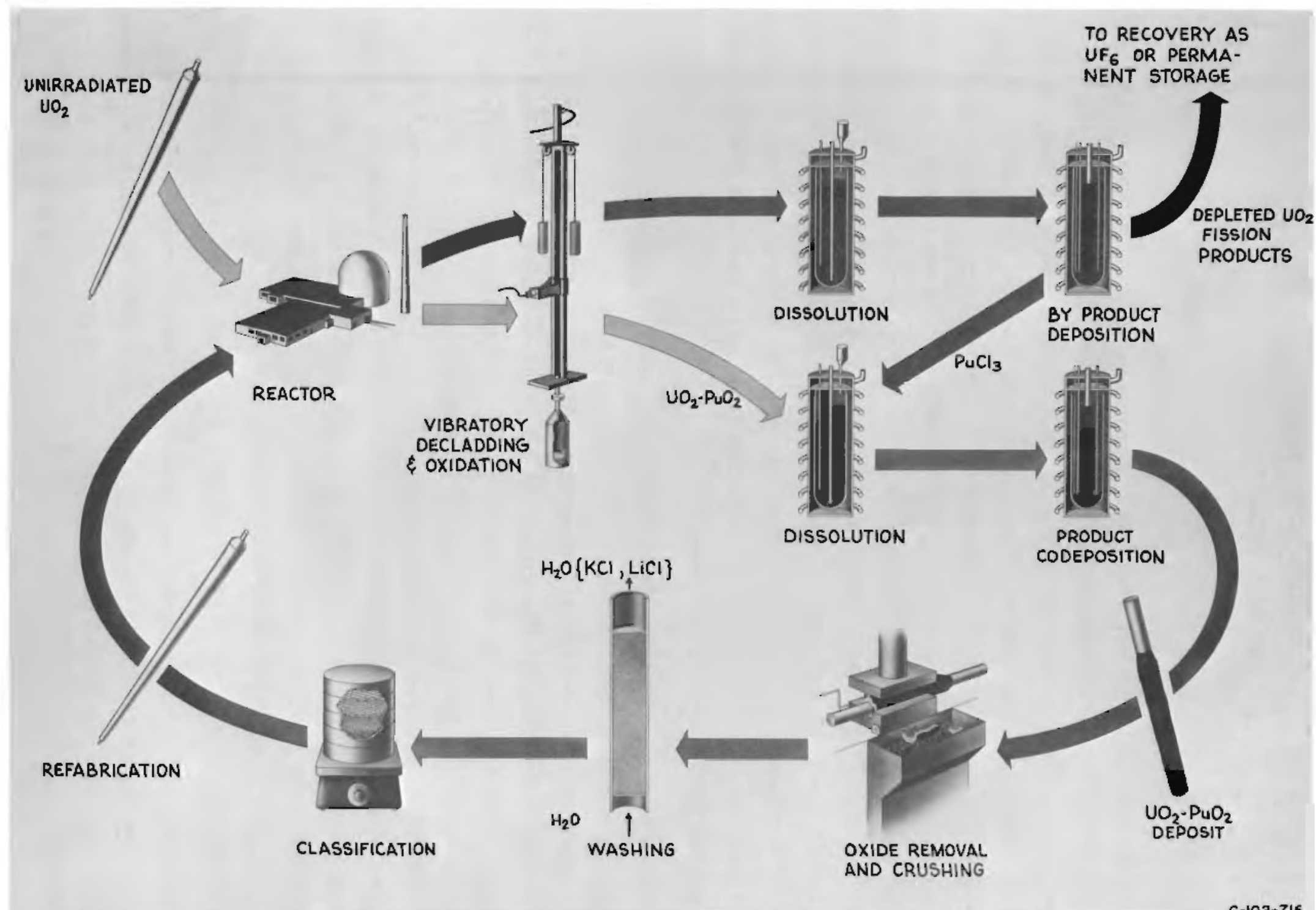

FIGURE 1

Close-Coupled Plutonium Recycle System 
development of the process was the production of electrolytic $\mathrm{UO}_{2}$ from molten chloride salt baths. This step has applications in itself to the winning of high density $\mathrm{UO}_{2}$ from uranium ores, ${ }^{(2)}$ and a preliminary economic evaluation of the costs of producing electrolytic $\mathrm{UO}_{2}$ has been made by $\mathrm{P}_{0} \mathrm{~W}_{0}$ Smith. (3) The preparation costs of solid-solution $\mathrm{UO}_{2}-\mathrm{PuO}_{2}$ by electrodeposition from molten chloride salt baths were evaluated by $W_{0} R_{0}$. Bond, (4) because solidsolution mixed oxides are desirable in fast reactors for control purposes. The preparation of an unique high density, crystalline $\mathrm{PuO}_{2}$ by precipitation from molten salt baths containing uranium has been demonstrated in laboratory equipment。(5)

This is the second of a series of terminal development reports of the Salt Cycle process. The first part ${ }^{(6)}$ deals with plutonium chemistry and contains a bibliography of the uranium chemistry of the Salt Cycle process。 This report deals with the engineering development of the unit operations necessary in the Salt Cycle process. The third report ${ }^{(7)}$ deals with the pilot plant demonstration of the process in a high-level radiochemical facility. The fourth report will detail remote refabrication of the fuel elements and the still unfinished in-reactor performance of the Salt Cycle product as a nuclear fuel。

This report is organized around the development of the unit operations shown in Figure 2. Because of contamination-control limitations in the pilot plant, plutonium was not used experimentally and stand-ins were employed where necessary. In the final version of the process, the $\mathrm{UO}_{2}-\mathrm{PuO}_{2}$ is removed from fuel rods by vibratory decladding, the $\mathrm{UO}_{2}$ is oxidized to $\mathrm{U}_{3} \mathrm{O}_{8}$. and the mixed oxide is dissolved in molten lithium chloride-potassium chloride by chlorine and hydrogen chloride gas. When uranium is to be separated from plutonium, the $\mathrm{UO}_{2}$ may be electrodeposited alone in the presence of a hydrogen chloride gas sparge, or the $\mathrm{PuO}_{2}$ may be precipitated alone by oxygen-chlorine or hydrogen gas sparges. Make-up $\mathrm{UO}_{2}$ or $\mathrm{PuO}_{2}$ may then be added to the bath, usually as an irradiated fuel element, and a $\mathrm{UO}_{2}-\mathrm{PuO}_{2}$ mixture electrodeposited with an oxygen-chlorine gas sparge. The mixed oxide is stripped from the electrode, crushed, washed with water, reduced with hydrogen if necessary, and sized for vibratory compaction into fuel elements. 


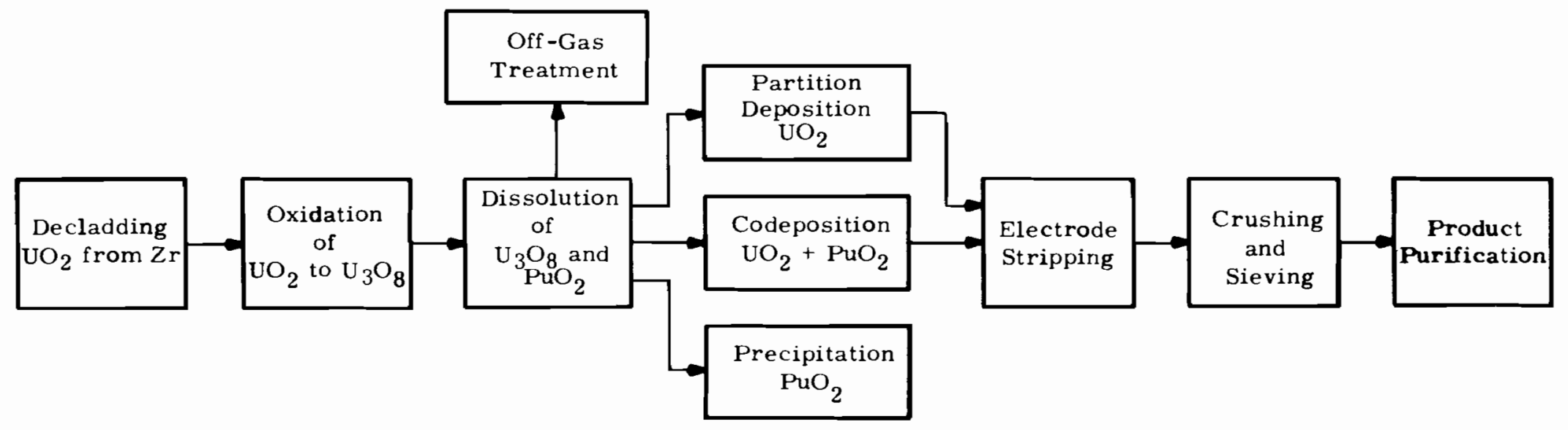

EQUIPMENT AND MATERIALS DEVELOPMENT

\begin{tabular}{|c|c|c|}
\hline $\begin{array}{l}\text { Electrode } \\
\text { Evaluation }\end{array}$ & $\begin{array}{l}\text { Molten Salt } \\
\text { Container } \\
\text { Evaluation }\end{array}$ & $\begin{array}{c}\text { Equipment } \\
\text { and } \\
\text { Instrumentation } \\
\text { Development }\end{array}$ \\
\hline
\end{tabular}

FIGURE 2

Salt Cycle Process Development 


\section{SUMMARY}

The engineering development of the unit operations used in the Salt Cycle process is detailed in this report. The development primarily involved pilot plant operations in the production of electrolytic $\mathrm{UO}_{2}$ and the design and evaluation of equipment to be used in remote operations for recycle of irradiated mixed oxide fuels.

Vibratory decladding with an air hammer was selected as the primary technique for fuel-cladding separation because of its short time cycle, effectiveness in removing all of the fuel from the cladding, and minimal waste disposal problems. For cold-swaged $\mathrm{UO}_{2}$, decladding times as short as two minutes for a $0,5-i n$. diam by 4 ft-long rod were demonstrated in remotely operable apparatus with no appreciable formation of radioactive dust. Chlorine gas (diluted with nitrogen for temperature control) was selected as the backup chemical decladding technique for Zircaloy-2 decladding. Scouting studies with oxidative decladding, and decladding of zircaloy-2 and stainless steel by chlorine gas or lead chloride in molten salts were also made.

Uranium dioxide was oxidized to $\mathrm{U}_{3} \mathrm{O}_{8}$ in remotely operable equipment to promote dissolution in the salt bath by reducing the particle size of the oxide. For 15-1b batches of $\mathrm{UO}_{2}$ a flow rate of 2 liters of air per minute for 24 hours was sufficient to prepare feed for dissolution, although only partial oxidation to $\mathrm{U}_{3} \mathrm{O}_{8}$ was accomplished throughout the bed in this time. Sintering of the oxide during temperature excursions was a major problem.

Pilot plant operations were conducted in 20-liter and 80-liter fused

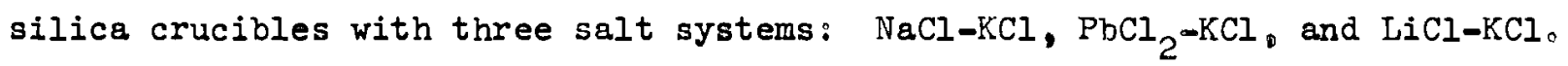
Primary purpose of the work in the $\mathrm{NaCl}-\mathrm{KCl}$ salt system was to produce $100 \mathrm{Ib}$ of electrolytic $\mathrm{UO}_{2}$ for evaluation as a fuel material, the dissolution of oxides was not studied。 Electrolytic deposition of $\mathrm{UO}_{2}$ from equimolar $\mathrm{NaCl}-\mathrm{KCl}$ at 700 to $800^{\circ} \mathrm{C}$ with uranyl chloride monohydrate feed was studied。 Although no initial dissolution was required with this feed material, water remaining in the bath raised the oxygen-to-uranium ratio of the product and had to be removed by hydrogen chloride or chlorine gas sparging Side reactions that produced $U(I V)$ in solution and corrosion of graphite anodes were major operating problems in this system. Dual vessel operations were also evaluated. 
The $\mathrm{PbCl}_{2}-\mathrm{KCl}$ system was operated at 600 to $700^{\circ} \mathrm{C}$, and dissolution of $\mathrm{UO}_{3}$ and $\mathrm{U}_{3} \mathrm{O}_{8}$ was achieved by sparging the salt bath with chlorine through quartz tubes. A reference electrode system was necessary to control the cathode-tomelt potential to prevent lead metal deposition during electrolysis. A maximum size deposit of $116 \mathrm{Ib}$ of $\mathrm{UO}_{2}$ was obtained in an 80 liter salt bath with Hastelloy $D$ cathodes. Disadvantages of this system were the high operating temperature, the volatilization of lead chloride that plugged off-gas lines, and the inability to remove small amounts of lead or lead chloride from the deposit.

The LiCl-KCl salt system was finally selected as the most suitable one. Although it is hygroscopic at room temperature, its use permits operation at only 500 to $600{ }^{\circ} \mathrm{C}$, and consequently long lifetimes for the metal exposed to the chlorine atmosphere in the vapor space are achieved. Dissolution rates were improved in this system by chlorine sparging with a submerged gas lift. Improved atmosphere control techniques consistently resulted in oxygen-touranium ratios below 2.01 , deposits exhibiting high densities, good crystal structure and chloride contents in the range 50 to $100 \mathrm{ppm}$.

Severe corrosion of metallic nickel-base cathodes beneath the deposit affected crystal structure, and porous graphite cathodes caused high carbon contamination of the product through mechanical interlocking. Hastelloy D cathodes were used in pilot plant runs in the $\mathrm{PbCl}_{2}-\mathrm{KCl}$ system with marginal corrosion rates, but corrosion rates were too great in the LiCl-KCl system. Platinum electrodes were severely corroded by chlorine at the salt-vapor interface, and interface protection devices proved unworkable. The cathode problem was finally solved by using graphite electrodes with impervious pyrolytic graphite coatings, which facilitated removal of the deposits from the electrodes and gave product carbon contents below $50 \mathrm{ppm}$.

Alternate container materials other than fused silica were evaluated. All metals corroded excessively, although nickel-aluminum alloys corroded least. Several types of graphite crucibles and susceptors were tested

(R)

The Union Carbide Company 
successfully with salt, but were rejected for use during codeposition because of the corrosion of graphite in oxygen and its ability to keep Pu(IV) from oxidizing. Other nonmetallic materials such as alumina offered no advantages over the brittle quartz.

Studies of the codeposition and partition steps, using cerium as a standin for plutonium, led to the conclusion that the oxygen-chlorine sparges necessary to oxidize plutonium to $\mathrm{Pu}(\mathrm{IV})$ during electrolysis were compatible with the production of deposits with good crystal structure and oxygen-touranium ratios below 2.01. Precipitation of $\mathrm{PuO}_{2}$ was studied by using a cerium stand-in. Adherence of the oxide to the quartz crucible and to gaslift recovery devices limited precipitate recoveries to less than $60 \%$ 。

Integrated crushing, grinding and sieving devices to produce the three narrow particle size distributions desired for obtaining high densities by vibratory compaction were evaluated. The following series of devices was selected for hot cell use. The deposit is stripped from the electrode, and cut up into half-inch chunks with a hydraulic press. After the $\mathrm{UO}_{2}$ is washed with water to remove the chloride salts, the $-4+10$ mesh and $-35+65$ mesh size fractions are made with a series of stepped parallel plates mounted in the press. Ball milling for 12 hours produced minus 200 mesh fines from the unwanted size fractions。

Chlorine and hydrogen chloride were removed from the off-gas by caustic scrubbers in all pilot plant operations, Continuous hydrogen peroxide additions to the caustic proved effective in destroying hypochlorite for subsequent storage of the caustic in stainless steel tanks. Recovery of chlorine and iodine entrapment from the off-gas by chlorine liquefaction at atmospheric pressure and $-100^{\circ} \mathrm{C}$ were also studied in the pilot plant。 DECLADDING

Studies of fuel element decladding for the Salt Cycle process were directed toward the following requirements: (1) a dry core for charging to the salt bath should be produced directly, (2) a minimum cladding waste volume should be produced, (3) the technique should be applicable to variable geometry fuel elements, and (4) decladding should not interfere chemically with 
subsequent dissolution and electrolysis of the fuel material. Aqueous decladding techniques were not considered in the experimental studies。 Three general types of decladding were briefly studied in laboratory-scale tests: (1) removal of the fuel from the cladding by mechanical vibration or oxidation of the $\mathrm{UO}_{2},(2)$ gas phase reactions of the cladding with chlorine or hydrogen chloride, and (3) dissolution of the cladding in molten salts by chlorine, hydrogen chloride or metal replacement reactions.

Mechanical decladding is applicable only to certain geometries but produces small quantities of wastes because the cladding is left as a compact metal. To provide an alternative for difficult fuel element geometries and for cladding that might be chemically bonded to the fuel, chemical decladding was also studied. Vibrational decladding was chosen for the hot cell demonstration, and gas phase decladding with nitrogen-diluted chlorine was developed as the backup chemical decladding technique。

Vibrational Decladding

In an initial test an 8-ft-long, 0,5-in,-diam, cold-swaged Plutonium Recycle Test Reactor (PRTR) fuel rod was fixed in a vertical position and $\mathrm{UO}_{2}$ was vibrated out the lower end after the end plug had been removed with a tubing cutter. The $\mathrm{UO}_{2}$ was easily removed using a small jack hammer as a vibrator. A second test was made with the same type of rod using an ultrasonic vibrator normally used for vibratory compaction of fuel elements. The $\mathrm{UO}_{2}$ was not removed from the fuel element by this method with the ultrasonic coupling device available. It was concluded from these scouting studies that the $\mathrm{UO}_{2}$ could be mechanically removed by a vibrational technique。

Since irradiated fuel might react with the cladding or sinter into a compact mass that would be difficult to vibrate loose, a test was conducted in the 327 Building Radiometallurgical Facility with a 2-ft-long by 0.5-in.diam section of a vibrationally compacted $1200 \mathrm{MWd} /$ ton fuel element irradiated in the PRTR. The section was held horizontally in a vise and a 5000blow/min air hammer was held against it by a remote manipulator. The $\mathrm{UO}_{2}$ flew out of the cladding during less than a minute "s hammering, indicating that little sintering had occurred. Close visual examination of the cladding showed a clean, metallic surface on the inside of the cladding。 
The initial success of vibrational decladding led to its selection as the primary remote decladding technique for removal of mixed oxide fuels from 19rod clusters in the Salt Cycle demonstration. (7) As shown in Figure 3, the developed decladder consisted of an air hammer with a speed up to 5000 blows/ min, a vertical stationary anvil that supported the fuel rod full length, and a counterweighted, manually-movable air hammer carriage fastened to the anvil. The hammer and anvil were shaped to give six points of contact on the fuel rod circumference.

Successful tests were made on 0.5-in.-diam Zircaloy-clad fuel rod segments. The full length 8 -ft fuel rods were bisected with a tubing cutter and placed against the anvil with the open end down into a tapered lower support containing a discharge into the oxide receiver. The lower support was equipped with a vacuum line to remove dust that might escape through the tapered fit during vibration. The upper support was then clamped over the fuel rod and cap by means of an air cylinder. As the vibratory hammer moved along the tube, the $\mathrm{UO}_{2}$ loosened and dropped into the receiver.

The $\mathrm{UO}_{2}$ was removed from vibratory-compacted fuel rods by vibrating only the bottom of the tube. Cold-swaged rods required only one pass with decladding times of about 2 min per half-rod, but a hot-swaged rod required 5 passes up and down the tube. The loading, decladding and unloading times were less than $10 \mathrm{~min}$ for any half-rod tested. The average losses of $\mathrm{UO}_{2}$ to the cladding from 7 cold-swaged half-rods and 3 vibratory-compacted half-rods were $0.072 \%$ and $0.014 \%$, respectively. These losses were measured by leaching the cladding with hot concentrated nitric acid and analyzing the aqueous solutions. The one hot-swaged rod tested gave an unexpectedly low waste loss of $0.013 \%$.

One could tell that a half-rod was empty from the sound of the air hammer. Weighing the rod and comparing it with the estimated cladding weight was also useful. In remote operations the manipulator operator could easily tell if appreciable oxide remained in the rod by feeling the shift in its center of gravity, by weighing it, or by probing inside the tube with a ruler. The initial design of the remotely operable decladder provided for a calibrated wire to pass into the tube as the air hammer moved up the fuel rod. This 

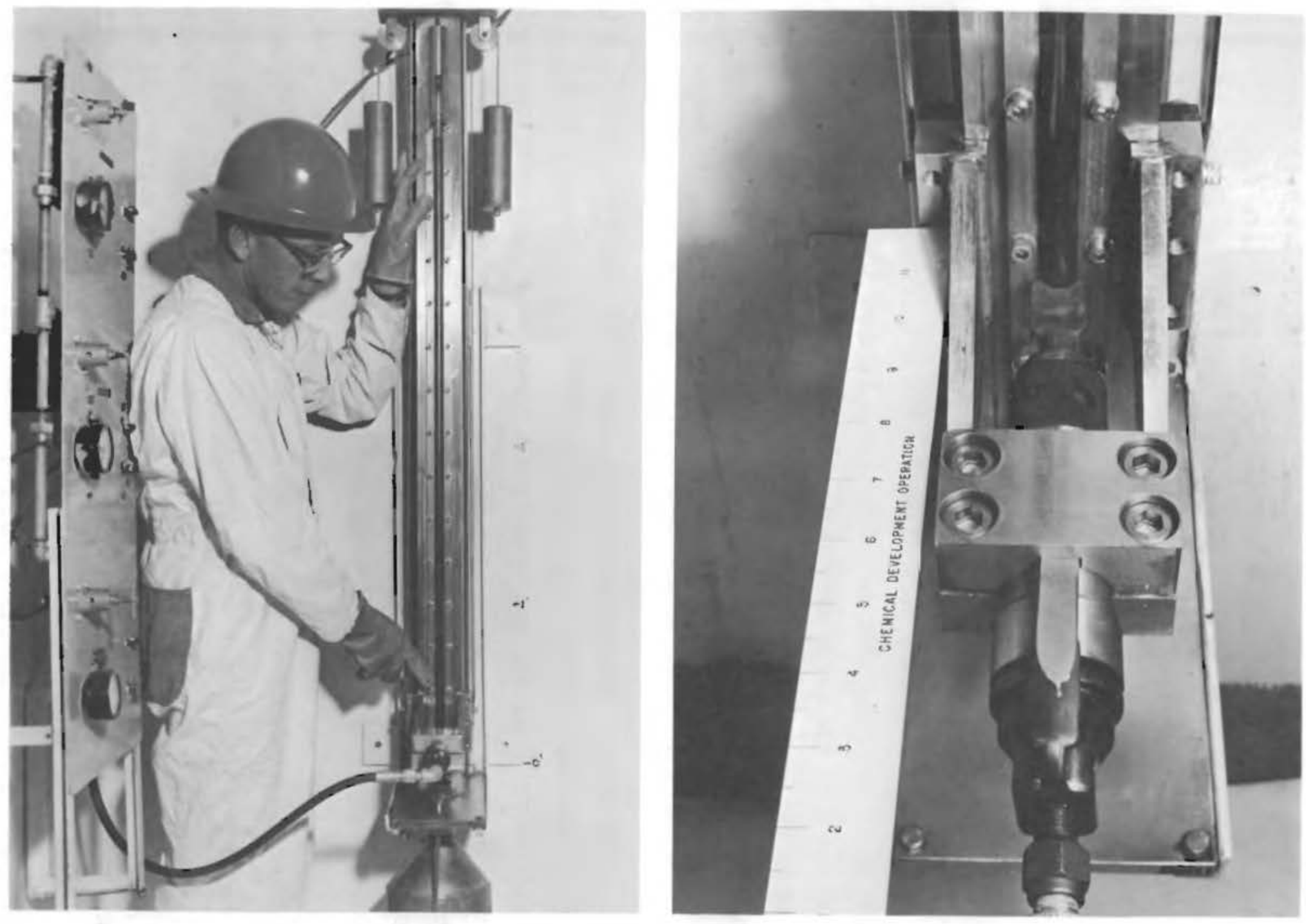

FIGURE 3

Vibratory Decladding Apparatus 
proved to be mechanically cumbersome and was abandoned before it worked successfully.

The satisfactory performance of the vibratory decladding apparatus with irradiated fuel is reported elsewhere. (7)

Oxidative Decladding

One approach to the removal of the fuel from the cladding was a method similar to that developed by Atomics International (8) for the Airox process in the re-enrichment of oxide fuels. The $\mathrm{UO}_{2}$ is oxidized with air or oxygen to produce $\mathrm{U}_{3} \mathrm{O}_{8}$ which is less dense than $\mathrm{UO}_{2}$ and expands, rupturing the cladding with the powder spilling out to a receiver.

A version of oxidative fuel-cladding separation was used by Benedict $(9)$ in the first laboratory scale Salt Cycle hot cell experiments. After the fuel rods were cut up into l-in. lengths, they were placed on a coarse screen above the salt pot and air was passed through the screen. The $\mathrm{U}_{3} \mathrm{O}_{8}$ dropped through the screen into the salt pot as it formed.

Two oxidative core removals were attempted in a pilot plant reactor used for gas phase dissolution studies. The objective was to operate at a temperature and gas flow rate which would split the 35-mil-thick zircaloy-2 cladding as the $\mathrm{UO}_{2}$ oxidized to $\mathrm{U}_{3} \mathrm{O}_{8}$ and thus provide uniform removal of the core from long fuel elements. The first test element was a 3-ft-long, 0.5-in.-diam fuel pin with 2 rows of 0.125 in. holes diametrically opposed and spaced an inch apart. When exposed to air at 425 to $535{ }^{\circ} \mathrm{C}$, the cladaing bulged as is shown in Figure 4 but did not split and very little $\mathrm{U}_{3} \mathrm{O}_{8}$ was removed. In a second run, a 22-in.-long fuel pin was exposed to oxygen at $600^{\circ} \mathrm{C}$ for $4 \mathrm{hr}$. Some oxidation occurred and the cladding bulged around the drilled holes. The run was continued at $720^{\circ} \mathrm{C}$ for an hour, during which the cladding split in three places, providing considerable area for further oxidative attack.

Further development of the oxidative decladding approach for use in the Salt Cycle demonstration was discontinued when it became clear that the mechanical operations and time cycles involved compared unfavorably with vibrational decladaing for the fuel elements to be used. 


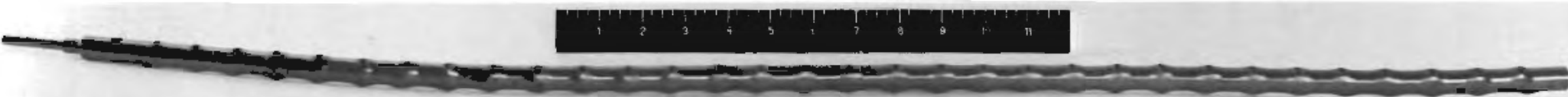

First Test at $425-535{ }^{\circ} \mathrm{C}$ for 6 Hours

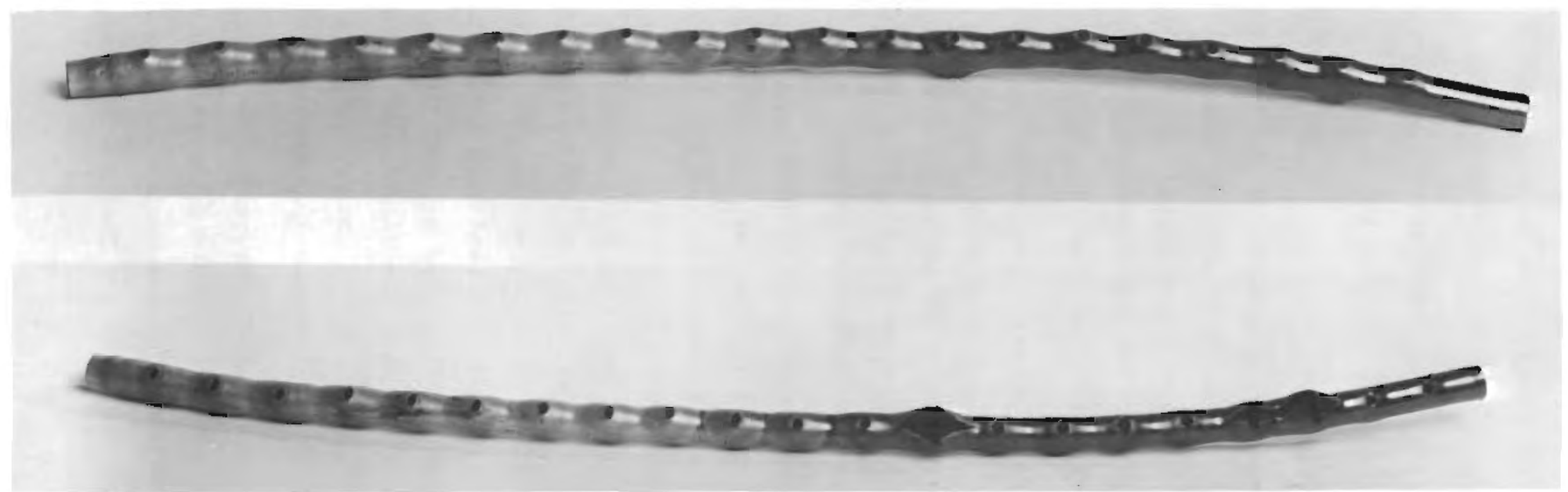

Second Test at $600^{\circ} \mathrm{C}$ for 4 Hours and at $720^{\circ} \mathrm{C}$ for $1 \mathrm{Hour}$

FIGURE 4

Oxidative Decladding Test Results 


\section{Gas-Phase Chlorination of Zircaloy}

Data on the gas phase chlorination and hydrochlorination of oxidized Zircaloy-2, using an alumina pellet bed for a heat transfer medium are summarized in Table I. A coupon of Zircaloy-2 was dissolved in chlorine gas in approximately $3 \mathrm{hr}$ with the reaction starting at $400{ }^{\circ} \mathrm{C}$ and the temperature rising to as high as $800^{\circ} \mathrm{C}$. The chlorine flow rate had to be adjusted from 170 to $15 \mathrm{ml} / \mathrm{min}$ to hold the reaction in control. In a second run using hydrogen chloride gas, the reaction did not occur at $15 \mathrm{ml} / \mathrm{min}$, but started and went smoothly at $55 \mathrm{ml} / \mathrm{min}$. The temperature varied from $400{ }^{\circ} \mathrm{C}$ to a $\max -$ imum of $480^{\circ} \mathrm{C}$, at which it remained constant. About $0.8 \mathrm{~g}$ of Zircaloy-2 was dissolved in $0.5 \mathrm{hr}$. The alumina pellets did not provide good heat transfer from the reaction zone because the bed could not be fluidized at the small gas flows used. The $\mathrm{ZrCl}_{4}$ reaction product condensed out on the cold surfaces at the top of the reactor, which indicated the necessity for equipment designed to avoid plugging the reactor chamber. The sublimation temperature of $\mathrm{ZrCl}_{4}$ is about $300{ }^{\circ} \mathrm{C}$.

The chlorination or hydrochlorination of Zircaloy-2 without a heat transfer medium such as alumina is difficult because of the highly exothermic reaction. However, heat transfer media are not desirable with $\mathrm{UO}_{2}$ cores because of the difficulty of separation of the core from the bed. Hence, mixing of the halogen gas with an inert gas was attempted to control the reaction. Chlorine was used exclusively in these studies to avoid the hydrogen production problem associated with the reaction of hydrogen chloride with zirconium.

Laboratory scouting studies made with coupons and small fuel pins to determine operable ratios of inert gas to chlorine are summarized in Table I. With the first fuel pin the $\mathrm{UO}_{2}$ core was exposed in $2.5 \mathrm{hr}$ but was not completely declad as shown in Figure 5. The reacting gas had an initial 4-to-1 nitrogento-chlorine ratio, which was gradually decreased to a 1-to-l ratio during the run. The decladding was not completed because of vapor deposition of $\mathrm{ZrCl}_{4}$ on the cooler areas of the element. In another decladding, the initial nitrogen-to-chlorine ratio was set at 1-to-l and reduced to 1-to-2 after an hour. All of the cladding except a small part of one end plug was removed in 


\begin{tabular}{|c|c|c|c|c|c|c|c|c|}
\hline 3un :io. & $\begin{array}{c}\text { Feed } \\
\text { Heterial } \\
\end{array}$ & Geometry & $\begin{array}{c}\text { Total } \\
\text { Sample } \\
\text { :ieight, } \\
\end{array}$ & $\begin{array}{l}\text { Turnace } \\
\text { memp, o0 }\end{array}$ & 335 & Rate, $\mathrm{ml} / \mathrm{min}$ & Time, hr & Remarks \\
\hline PL-1 & $\begin{array}{l}\text { Oxidized } \\
\text { Zircaloy }-2\end{array}$ & $\begin{array}{l}3 / 4 \text { in. tubing } \\
\text { section in an } \\
\text { alumina bed }\end{array}$ & 2.1 & 400 & $\mathrm{Cl}_{2}$ & 170 to 14 & 1.0 & $\begin{array}{l}\text { Formed } \mathrm{ZrCl}_{4} \text { (white powdery } \\
\text { layer on all cold surfaces } \\
\text { above reaction bed). } \\
\text { Produced conslierable heat } \\
\text { (up to } 300^{\circ} \mathrm{C} \text { ). }\end{array}$ \\
\hline PI-2 & $\begin{array}{l}\text { Oxidized } \\
\text { Zircaloy }-2\end{array}$ & $\begin{array}{l}3 / 4 \text { in. tubing } \\
\text { section in an } \\
\text { alumina bed. }\end{array}$ & 2.0 & 400 & $\mathrm{HCI}$ & 14 to 56 & 0.5 & $\begin{array}{l}0.8 \text { g reacted forminB } \mathrm{ZrCl}_{4} \text {. } \\
\text { Produced some heat (up to } \\
480^{\circ} \mathrm{C} \text { ). }\end{array}$ \\
\hline$G P-1$ & $\begin{array}{l}\text { Zircaloy-2 } \\
\text { clad } \mathrm{UO}_{2} \\
\text { fuel } \\
\text { element }\end{array}$ & $\begin{array}{l}1 / 2 \text { in. } x 3-1 / 2 \text { in. } \\
\text { pln }\end{array}$ & 90.5 & $\begin{array}{r}420 \\
\text { to } \\
590\end{array}$ & $\begin{array}{l}\mathrm{Cl}_{2} \\
\text { snd } \\
\mathrm{I}_{2}\end{array}$ & $\begin{array}{l}50 \text { to } 150 \\
150 \text { to } 200\end{array}$ & 2.4 & $\begin{array}{l}\text { Fuel core was exposed and one } \\
\text { end plug totally dissolved. }\end{array}$ \\
\hline GP-2 & $\begin{array}{l}\text { Zircaloy-2 } \\
\text { clad } \\
\mathrm{UO}_{2} \text { fuel } \\
\text { element }\end{array}$ & $\begin{array}{l}1 / 2 \text { in. } \times 3-1 / 2 \text { in. } \\
\text { pin }\end{array}$ & 88.7 & $\begin{array}{r}510 \\
\text { to } \\
580\end{array}$ & $\begin{array}{l}\mathrm{Cl}_{2} \\
\text { and } \\
\mathrm{N}_{2}\end{array}$ & $\begin{array}{l}150 \text { to } 300 \\
150\end{array}$ & 2.5 & $\begin{array}{l}\text { Cladding was completely re- } \\
\text { moved and only part of the } \\
\text { upper end plug remained. } \\
\text { fave off much } \mathrm{ZrCl}_{4} \text { at } 500 \text { to } \\
525^{\circ} \mathrm{C} \text {. }\end{array}$ \\
\hline$M P D-1$ & $\begin{array}{l}\text { Zircaloy-2 } \\
\text { clad } \\
\text { PRTR ruel } \\
\text { rod }\end{array}$ & $1 / 2$ in. $x 36$ in. & 1226. & $\approx 400$ & $\begin{array}{l}\mathrm{Cl}_{2} \\
\text { and } \\
\mathrm{T}_{2}\end{array}$ & $\begin{array}{l}2000 \\
2000\end{array}$ & 3.0 & Wt loss $=65.9 \mathrm{~g}$. \\
\hline YPD-2 & $\begin{array}{l}\text { Zircaloy-2 } \\
\text { clad } \\
\text { PRTR fuel } \\
\text { rod }\end{array}$ & $1 / 2$ in. $x 36$ in. & 1177 & $\approx 500$ & $\begin{array}{l}\mathrm{Cl}_{3} \\
\mathrm{3}-\mathrm{I}_{2} \\
\mathrm{I}_{2}\end{array}$ & $\begin{array}{l}1500 \text { to } 2000 \\
1500\end{array}$ & 1.7 & $\begin{array}{l}\text { Wt loss }=60 \mathrm{~g} \text {. } \\
\text { Caustic scrubber blowback caused } \\
\text { termination of this test. In- } \\
\text { adequate vacuum to remove } \mathrm{ZrCl}_{4} \text {. }\end{array}$ \\
\hline
\end{tabular}



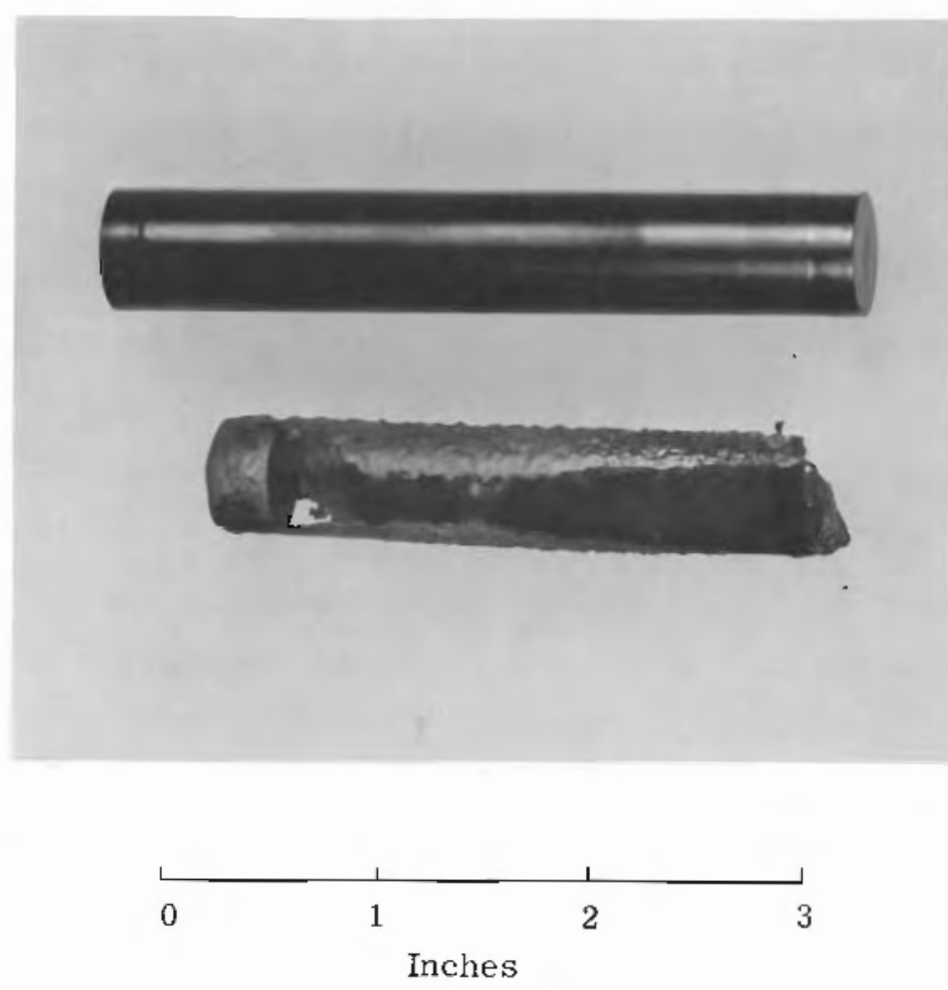

Run GP-1

$\mathrm{T}=420^{\circ} \mathrm{C}$ to $590{ }^{\circ} \mathrm{C}, \mathrm{N}_{2} / \mathrm{Cl}_{2}=4 / 1$ to $1 / 1$, Time $2.5 \mathrm{hr}$

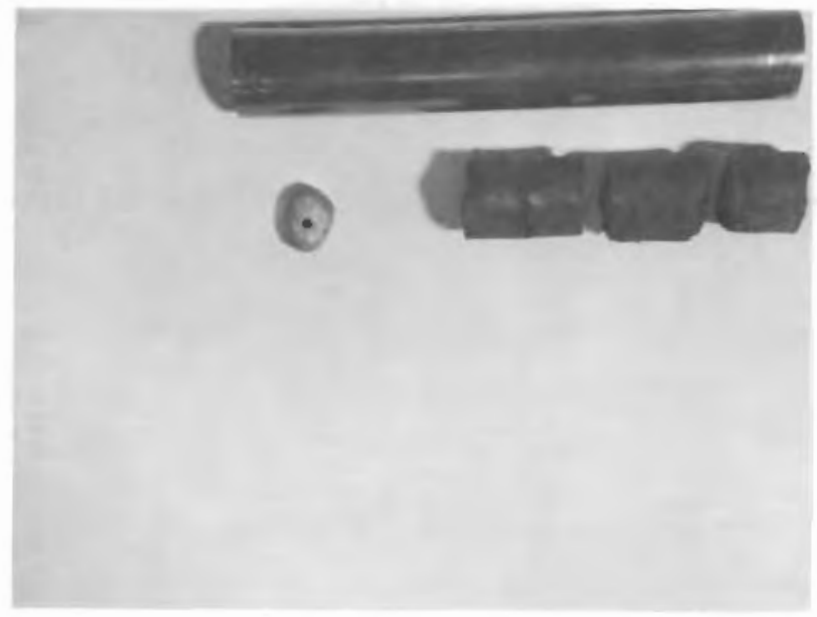

Run GP-2

$\mathrm{T}=415^{\circ} \mathrm{C}$ to $645^{\circ} \mathrm{C}, \mathrm{N}_{2} / \mathrm{Cl}_{2}=1 / 1$ to $1 / 2$, Time $2.5 \mathrm{hr}$

FIGURE 5

Gas-Phase Chlorination of Oxidized Zircaloy-2 
$2.5 \mathrm{hr}$. The starting temperature was $415^{\circ} \mathrm{C}$. The rnaximum temperatures observed during the first and second parts of the run were $535^{\circ} \mathrm{C}$ and $645^{\circ} \mathrm{C}$, respectively.

Two chlorinations of Zircaloy-2 were made in a small pilot plant reactor (49-in.-long by 2.5-in.-diam) containing a 3-ft section of a 0.5-in.-diam PRTR fuel rod. In the first run 4 liters/min of a l-to-l nitrogen-to-chlorine ratio were used at temperatures between 425 and $575^{\circ} \mathrm{C}$. Approximately $33^{\circ}$ $(65 \mathrm{~g})$ had been removed when the run was stopped in $30 \mathrm{~min}$ because of plugging of the off-gas line with $\mathrm{ZrCl}_{4}$. The second run was made with a gas preheater in the line ahead of the reactor, but was stopped by a scrubber blow-back after $30 \%$ of the cladding had been removed. In both runs the part of the $\mathrm{ZrCl}_{4}$ condensed on the walls of the reaction vessel contained about 0.1 wt $\%$ uranium.

Decladding by Sparging Molten Salts

Decladding of Zircaloy-2 by sparging molten salts with halogen gases is summarized in Table II. Coupons of oxidized Zircaloy $35 \mathrm{mils}$ thick, weighing from 2 to $2.5 \mathrm{~g}$, were reacted with chlorine and hydrogen chloride using $30 \mathrm{~g}$ of equimolar $\mathrm{NaCl}-\mathrm{KCl}$ molten salt as a heat and mass transfer medium. Complete dissolution of the Zircaloy-2 occurred at $800{ }^{\circ} \mathrm{C}$ with $240 \mathrm{ml} / \mathrm{min}$ hydrogen chloride flow in less than $2.5 \mathrm{hr}$. With $84 \mathrm{ml} / \mathrm{min}$ of $\mathrm{HCl}$ complete dissolution did not occur, but with a $\mathrm{HCl}$ sparge of $200 \mathrm{ml} / \mathrm{min}$, the coupon dissolved in less than $1.5 \mathrm{hr}$. The rates of dissolution were evidently strongly influenced by the condition of the oxide film on the Zircaloy. In an experiment using $140 \mathrm{ml} / \mathrm{min}$ chlorine gas rather than hydrogen chloride, $1.3 \mathrm{~g}$ of Zircaloy-2 were dissolved in $1.7 \mathrm{hr}$ indicating little change in dissolution rate with a change in reactant gas. In these experiments the $\mathrm{ZrCl}_{4}$ reaction product was not volatilized but remained in the solid and black $\mathrm{ZrO}_{2}$ was noted in the melts.

In an effort to speed the reaction of Zircaloy-2 with chlorine, 0.5 mol\% $\mathrm{CuCl}$ was added to the initial $\mathrm{NaCl}-\mathrm{KCl}$ melt. The coupon completely dissolved in $50 \mathrm{~min}$ at a chlorine flow of $170 \mathrm{ml} / \mathrm{min}$. Doubling the catalyst concentration did not increase the dissolution rate. 


\section{TABLE II}

DECLADDING BY GAS SPARGE IN MOLTEI SALTS

Salt System: $30 \mathrm{~g}$ of $50 \mathrm{~mol} \% \mathrm{NaCl}-50$ mol\% $\mathrm{KCl}$

Cladding: $\quad 3 / 4 \mathrm{in}$. diam section of oxidized zircaloy-2 tubing

Temperature: $800^{\circ} \mathrm{C}$

Run No.

Sample Weight, $g$

Gas Rate,

$\underline{\mathrm{ml} / \mathrm{min}}$

\section{Hydrogen Chloride Gas Sparge}

$\begin{array}{llrl}14-C & 2 & 84 & 1.75 \\ 14-D & 2 & 240 & 2.33 \\ 14-E & 2.1 & 200 & 1.58\end{array}$

Chlorine Gas Sparge with Cuprous Chloride Catalyst

\begin{tabular}{lcccc} 
Run No. & $\begin{array}{c}\text { Sample } \\
\text { Weight, g }\end{array}$ & $\begin{array}{c}\text { Weight } \\
\text { CuCl,g }\end{array}$ & $\begin{array}{c}\text { Gas Rate, } \\
\text { ml/min }\end{array}$ & $\frac{\text { Time, hr }}{170}$ \\
\cline { 2 - 2 } & 1.5 & 0.22 & 0.92 \\
PI-3-C & 2.2 & 0.22 & 149 & 0.50 \\
PL-10 & 2.2 & 0.44 & $\begin{array}{c}149-0 \\
\text { spasmodic }\end{array}$ & $\sim 1$. \\
PL-10B & 1.9 & 0.44 & 149 & 0.50
\end{tabular}

Time, hr

1.75

.33

.58

\section{Remarks}

Zircaloy did not dissolve.

Tubing almost completely dissolved. Left some black crud in salt which appeared to be $\mathrm{ZrO}_{2}$.

All dissolved except for some very fine particles.

Remarks

All dissolved.

1.6 g dissolved.

Used 10 minute air sparge following $\mathrm{Cl}_{2}$.

$\mathrm{Cl}_{2}$ leak, experiment stopped. 1.45 of the Zircaloy dissolved, turning salt black.

$1.3 \mathrm{~g}$ of the Zircaloy dissolved Employed $10 \mathrm{~min}$ air sparge following chlorination. 


\section{Metal Replacement Reaction}

Scouting studies on the metal replacement reaction of zircaloy-2 with $\mathrm{PbCl}_{2}$, which has been previously studied by Argonne National Laboratory in the development of the ARCO process, (10) are summarized in Table III. Zircaloy coupons dissolved in a $\mathrm{PbCl}_{2}$ bath in about $2 \mathrm{hr}$ within a temperature range of 450 to $550{ }^{\circ} \mathrm{C}$. The $\mathrm{ZrCl}_{4}$ was evolved and the lead reaction product settled to the bottom of the reaction vessel.

An equivalent reaction time was observed in an equimolar $\mathrm{PbCl}_{2}-\mathrm{KCl}$ molten salt. The $\mathrm{ZrCl}_{4}$ was retained in the melt, however. In an equimolar $\mathrm{NaCl}-\mathrm{KCl}$ melt at $800^{\circ} \mathrm{C}$, a Zircaloy coupon was dissolved in 15 min using a stoichiometric quantity of $\mathrm{PbCl}_{2}$, leaving the $\mathrm{ZrCl}_{4}$ reaction product in the melt. Doubling the amount of $\mathrm{PbCl}_{2}$ did not appear to increase the reaction rate.

\section{Effect of Decladding on Electrolytic $\mathrm{UO}_{2}$ Deposition}

In an attempt to integrate the decladding studies with the electrolytic recovery of $\mathrm{UO}_{2}$, a 3.5-in,-long fuel pin was declad in $\mathrm{PbCl}_{2}$ at $550{ }^{\circ} \mathrm{C}$ by the metal replacement reaction, as shown in Table IV. KCl was then added to make an equimolar $\mathrm{PbCl}_{2}-\mathrm{KCl}$ melt. The $\mathrm{UO}_{2}$ from the pin was dissolved and the lead from the decladding reaction regenerated with a chlorine sparge of $270 \mathrm{ml} / \mathrm{min}$ over a $4-\mathrm{hr}$ period. Subsequent electrolysis at $500^{\circ} \mathrm{C}$ provided only a small deposit of $\mathrm{UO}_{2}$ and a very low current efficiency. Analysis of the melt showed that the lead had not been completely regenerated, perhaps accounting for the poor electrolysis.

Further electrolysis tests with melts containing Zircaloy as an impurity indicated that the retention of dissolved cladding in the salt is not desir-

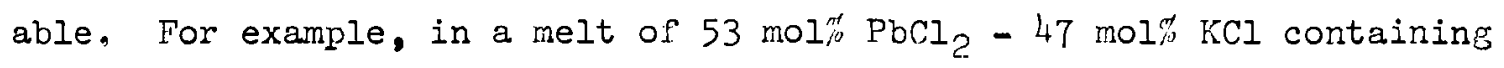
2.5 wt\% dissolved zirconium, only a small deposit of low-grade $\mathrm{UO}_{2}$ crystals was obtained, while in a similar melt without zirconium present a good deposit of $\mathrm{UO}_{2}$ was obtained. Zircaloy appeared to have little effect on electrolyses in a $\mathrm{NaCl}-\mathrm{KCl}$ melt. However, even in that system there is still an incentive for cladding removal before charging feed to the salt melt because the buildup of high concentrations of $\mathrm{ZrCl}_{4}$ in the bath would result in $\mathrm{ZrCl}_{4}$ volatilization. 
TABLE III

DECIAADDING WIMH METAL REPLACEMENT REACTION

\begin{tabular}{|c|c|c|}
\hline Run Io. & $\begin{array}{c}\text { Sample } \\
\text { Weight, \& } \\
\end{array}$ & Salt System \\
\hline Feed: & & \\
\hline$P I-6$ & 3.0 & $\begin{array}{l}53 \mathrm{~mol} \% \mathrm{PbCl}_{2} \\
47 \mathrm{~mol} \% \mathrm{KCl} \\
61 \mathrm{~g} \mathrm{~Pb}\end{array}$ \\
\hline$P L-7$ & 3.0 & $\begin{array}{l}60 \mathrm{~g} \mathrm{PbCl} \\
82 \mathrm{~g} \mathrm{~Pb}\end{array}$ \\
\hline
\end{tabular}

Temp, ${ }^{\circ} \mathrm{C}$

Remarks

Feed: $3 / 4$ inch diam section of oxidized Zircaloy

\begin{tabular}{|c|c|c|}
\hline PL-4 & 1.9 & $60 \mathrm{~g} \mathrm{PbCl}_{2}$ \\
\hline PL -5 & 2.2 & $\begin{array}{l}53 \text { mol\% } \mathrm{PbCl}_{2} \\
47 \mathrm{~mol} \% \mathrm{KCl}\end{array}$ \\
\hline$P L-11$ & 2.2 & $\begin{array}{lll}25.2 & \mathrm{~g} & \mathrm{PbCl} \\
14.8 \mathrm{~g} & \mathrm{KCl}-\mathrm{FaCl}\end{array}$ \\
\hline$P L-11-\mathrm{B}$ & 2.0 & $\begin{array}{ll}12.5 \mathrm{~g} & \mathrm{PbCl}_{2} \\
20 \mathrm{~g} & \mathrm{KCl}-\mathrm{JaCl}\end{array}$ \\
\hline
\end{tabular}

All dissolved producing heat (up to $550{ }^{\circ} \mathrm{C}$ ).
Most dia not dissolve.
$>95 \%$ of the $U$ found in interface

layer.

Most did not dissolve.

$>95 \%$ of the $U$ found in interface

layer.

$81 \%$ volatilized, lead was left in

bottom portion of melt.

All dissolved and stayed in solution. Produced heat (up to $550^{\circ} \mathrm{C}$ ).

Used $100 \%$ excess $\mathrm{PbCl}_{2}$. Rapid reaction when $\mathrm{Zr}$ dropped into salt and no $\mathrm{ZrCl}_{4}$ was given off.

All dissolved.

Used stoichiometric amount of $\mathrm{PbCl}_{2}$. Zr turned red when dropped in $700^{\circ} \mathrm{C}$ salt and gave off gas bubbles which were absorbed in solution. All dissolved, no volatilization. 


\begin{tabular}{|c|c|c|c|c|c|c|c|c|}
\hline Run No. & $\begin{array}{c}\text { Feed } \\
\text { Material } \\
\end{array}$ & (reometry & $\begin{array}{c}\text { Sample } \\
\text { Weight. }\end{array}$ & Salt System & Teme, ${ }^{\circ} \mathrm{C}$ & $\begin{array}{l}\text { Chlorine } \\
\text { Gas Rate } \\
\mathrm{ml} / \mathrm{min} \\
\end{array}$ & $\begin{array}{c}\text { Sparge } \\
\text { Time, hr } \\
\end{array}$ & Remarks \\
\hline PL -15 & $\begin{array}{l}\mathrm{UO}_{2} \text { fuel } \\
\text { element }\end{array}$ & $\begin{array}{l}1 / 2 " \times 3-1 / 2 " \\
\text { pin }\end{array}$ & $\begin{array}{l}34.9 \mathrm{zr} \\
52.9 \mathrm{UO}_{2}\end{array}$ & $\begin{array}{l}\mathrm{PbCl}_{2} \\
1750_{\mathrm{B}}\end{array}$ & 600 & 270 & 2.5 & $\begin{array}{l}\text { Zr dissolved, } \mathrm{ZrCl}_{4} \text { volatilized. } \\
\text { Added enough } \mathrm{KCl} \text { to obtain } 53 \text { molio } \\
\mathrm{PbCl}_{2}-47 \mathrm{~mol} \% \mathrm{KCl} \text {, added } 7.5 \mathrm{~B} \\
\text { of CuCl as catalyst and electro- } \\
\text { lyzed (poor electrolysis product). }\end{array}$ \\
\hline PL-16 & $\mathrm{UO}_{2}$ & 200 mesh & 100 & $\begin{array}{l}53 \mathrm{~mol}^{\circ} \mathrm{PbCl}_{2} \\
47 \mathrm{mol \%} \mathrm{KCl} \\
1500 \mathrm{~B} \\
\text { CuCl } 3 \mathrm{~B}\end{array}$ & 550 & 150 & 2.5 & $\begin{array}{l}\text { Electrolysis - poor deposit. } \\
\text { Experiment terminated by cracked } \\
\text { crueible. }\end{array}$ \\
\hline PL-18 & $\mathrm{UO}_{2} \mathrm{Cl}_{2} \cdot \mathrm{H}_{2} \mathrm{O}$ & Soluble Salt & 140 & $\begin{array}{l}53 \operatorname{mol}^{\circ} \mathrm{PbCl}_{2} \\
47 \mathrm{~mol} \mathrm{KCl} \\
2.5 \mathrm{~g} \mathrm{Zr} \\
\text { Tot } 1592.5 \mathrm{~B}\end{array}$ & 550 & 150 & 3.0 & $\begin{array}{l}\text { Very small, poor deposit. Poorly } \\
\text { adherent to electrode. } \\
1.5 \mathrm{~V} \text { during } 1 \mathrm{hr} \text { electrolysis. }\end{array}$ \\
\hline PL-18B & $\mathrm{UO}_{2} \mathrm{Cl}_{2} \cdot \mathrm{H}_{2} \mathrm{O}$ & Soluble Salt & 140 & $\begin{array}{l}53 \text { mol\% } \mathrm{PbCl}_{2} \\
47 \text { mol\% } \mathrm{KCl} \\
\text { Total } 1500_{6}\end{array}$ & 550 & 150 & 2.25 & $\begin{array}{l}\text { Duplicate of PL-18 without } 2 \mathrm{r} \\
\text { present. } \\
\text { :huch larger deposit than in PL-18. } \\
1 \text { br electrolysis at } 1.5 \mathrm{~V} \text {. }\end{array}$ \\
\hline PL-21 & $\mathrm{w}_{2} \mathrm{Cl}_{2} \cdot \mathrm{H}_{2} \mathrm{O}$ & Soluble Salt & 70 & $\begin{array}{l}50 \mathrm{~mol} \% \mathrm{KCl} \\
50 \mathrm{~mol} \% \mathrm{NaCl} \\
2.4 \mathrm{~B} \mathrm{Zr} \\
\text { Totel } 702.4 \mathrm{~B}\end{array}$ & 800 & 150 & 2.3 & $\begin{array}{l}\text { Fair deposit on cathode. There } \\
\text { ras an undissolved plece of } \mathrm{Zr} \text { in } \\
\text { the bottom of the bath that had a } \\
\text { like deposit of } \mathrm{UO}_{2} \text { on it. } \\
(21 \mathrm{hr} \text { electrolysis at } 1.5 \mathrm{v}) \text {. }\end{array}$ \\
\hline PL-21B & $\mathrm{UO}_{2} \mathrm{Cl}_{2} \cdot \mathrm{H}_{2} \mathrm{O}$ & Soluble Salt & 70 & $\begin{array}{l}50 \mathrm{~mol} \% \mathrm{KCl} \\
50 \mathrm{~mol} \% \mathrm{NaCl} \\
5 \mathrm{~g} \mathrm{TlCl} \\
2.2 \mathrm{~g} \mathrm{Zr} \\
\text { Total } 707.2 \mathrm{~B}\end{array}$ & 800 & 150 & 2.5 & $\begin{array}{l}\text { Good deposit with good crystal } \\
\text { structure. ( }(1.5 \mathrm{hr} \text { electrolysis } \\
\text { at } 21.5 \mathrm{~V}) .\end{array}$ \\
\hline PL 23 & $\mathrm{UO}_{2} \mathrm{Cl}_{2} \cdot \mathrm{H}_{2} \mathrm{O}$ & Soluble Salt & 140 & $50 \mathrm{~mol}^{\%} \mathrm{PbCl}_{2}$ & 600 & 150 & 3.0 & $\begin{array}{l}\text { Fair deposit. } \\
(0.58 \mathrm{hr} \text { electrolysis at } 1.5 \mathrm{v})\end{array}$ \\
\hline PL-28 & $\begin{array}{l}\mathrm{UO}_{2} \text { fuel } \\
\text { element }\end{array}$ & $\begin{array}{l}1 / 2 " \times 3-1 / 2 " \\
\text { pin }\end{array}$ & $\begin{array}{l}36 \mathrm{Zr}^{\mathrm{zr}} \\
53.7 \mathrm{UO}_{2}\end{array}$ & $\begin{array}{l}70 \mathrm{~mol}_{\mathrm{i}}^{\mathrm{KCl}} \\
30 \mathrm{~mol} \% \mathrm{PbCl}_{2} \\
\text { 2+il } 10 \mathrm{~g} \\
\text { Total } 150 \mathrm{~g}\end{array}$ & 500 & 270 & 3.5 & $\begin{array}{l}\text { Gave off copious quantity of } 2 \mathrm{r} C 1_{4} \\
\text { during dissolution. Very small } \\
\text { deposit on cathode - gostly near } \\
\text { interface. } \\
(1.5 \mathrm{hr} \text { electrolysis at } 1.5 \%)\end{array}$ \\
\hline
\end{tabular}




\section{Chlorination of Stainless Steel}

Information from work at Brookhaven National Laboratory (11,12) indicated that gas phase chlorination of stainless steel required higher temperatures than for Zircaloy (above $600^{\circ} \mathrm{C}$ ) and had a greater tendency toward an uncontrollable reaction. Therefore dissolution by chlorine was studied only with molten salts as heat transfer media. The results generally confirmed the high temperature requirements for stainless steel dissolution found at the other sites.

The dissolution tests using 35-mil-thick, $2.5 \mathrm{~g}$ coupons of 316 stainless steel are summarized in Table $V$. A stainless steel coupon lost $1.1 \mathrm{~g}$ in $30 \mathrm{~min}$ in a $\mathrm{NaCl}-\mathrm{KCl}$ melt with $0.5 \mathrm{~mol} \% \mathrm{CuCl}$ catalyst at $750^{\circ} \mathrm{C}$. In a control test, a coupon was not significantly attacked in the absence of the $\mathrm{CuCl}$ catalyst. A stainless steel coupon did not dissolve in $\mathrm{PbCl}_{2}$ at $500{ }^{\circ} \mathrm{C}$ by the metal replacement reaction alone but dissolved in about $40 \mathrm{~min}$ with the evolution of brown fumes when $150 \mathrm{ml} / \mathrm{min}$ of chlorine was sparged through the melt. Stainless steel did not dissolve in a NaCl-KCl melt at $800^{\circ} \mathrm{C}$ by the metal replacement reaction with $\mathrm{PbCl}_{2}$. This lack of success is in agreement with thermodynamic calculations based on the pure substances. OXIDATION

The oxidation of $\mathrm{UO}_{2}$ to $\mathrm{U}_{3} \mathrm{O}_{8}$ is performed in the Salt Cycle process to increase the reactivity of the oxide in the subsequent dissolution with chlorine in the molten salt bath. Although $\mathrm{U}_{3} \mathrm{O}_{8}$ does dissolve an order of magnitude more rapidly than $\mathrm{UO}_{2}$ with the same particle size, (13) the increased rate of dissolution of oxidized material is due primarily to the increase in surface area of the solid, caused by the fracturing of the solid as it is converted to less dense $\mathrm{U}_{3} \mathrm{O}_{8}$. Another result of oxidation which probably has a beneficial effect on dissolution is the greater ease of suspension of the smaller particles during stirring by the chlorine gas. The inclusion of several air-oxidation hydrogen-reduction cycles on the oxide is also believed to increase the reactivity of the oxide, presumably by further reducing the particle size and by creating active sites for dissolution. $(7,8)$ 
Feed: Section of $3 / 8$ inch diam 316 Stainless Steel Tubing.

\begin{tabular}{|c|c|c|c|c|c|c|}
\hline Run INo. & $\begin{array}{l}\text { Sample } \\
\text { Weight, g }\end{array}$ & Salt Composition & Tempe ${ }^{\circ} \mathrm{C}$ & $\begin{array}{l}\text { Chlorine jas } \\
\text { Rate, ml/min }\end{array}$ & $\begin{array}{l}\text { Sparge } \\
\text { mime, hr }\end{array}$ & Remarks \\
\hline PL-12 & 2.5 & $\begin{array}{l}50 \mathrm{~mol} \% \mathrm{KCl} \\
50 \text { mol\% } \mathrm{NaCl} \\
0.32 \mathrm{~g} \mathrm{CuCl} \text { catalyst } \\
30 \mathrm{~g}\end{array}$ & 750 & 149 & 0.50 & $\begin{array}{l}\text { l.l g dissolved, the remaining } \\
\text { was gray in color and easily } \\
\text { crumbled after drying. }\end{array}$ \\
\hline PL-12B & 2.2 & $\begin{array}{l}50 \mathrm{~mol} \% \mathrm{KCl} \\
50 \mathrm{~mol} \% \mathrm{NaCl} \\
30 \mathrm{E}\end{array}$ & 750 & 149 & 0.50 & $\begin{array}{l}0.2 \mathrm{~g} \text { weight loss. } \\
\text { Showed no sign of attack. }\end{array}$ \\
\hline PL-13 & 2.4 & $\begin{array}{l}\mathrm{PbCl}_{2} \\
40 \mathrm{~g}\end{array}$ & 600 & 0 & -- & $\begin{array}{l}0.1 \mathrm{~g} \text { weight loss. } \\
\text { No visible sign of attack. }\end{array}$ \\
\hline PL-13B & 2.3 & $\begin{array}{l}\mathrm{PbCl}_{2} \\
40 \mathrm{~g}\end{array}$ & 600 & 149 & 0.50 & $\begin{array}{l}\text { Dissolved completely. } \\
\text { Released dark brown smoke } \\
\text { during dissolution. }\end{array}$ \\
\hline$P I-14$ & 2.2 & $\begin{array}{ll}25 \mathrm{~g} & \mathrm{PbCl} \\
20 & \mathrm{~g} \\
\mathrm{KCl}-\mathrm{JaCl}\end{array}$ & 650 & 0 & -- & No reastion, salt turned brown. \\
\hline PL-14B & 2.0 & $\begin{array}{l}12.5 \mathrm{~g} \mathrm{PbCl} \\
20 \mathrm{~F} \mathrm{KCl}-\mathrm{NaCl}\end{array}$ & 650 & 0 & -- & No reaction. \\
\hline
\end{tabular}


For the bulk of the cold pilot plant work, it was sufficient to place the $\mathrm{UO}_{2}$ in metal trays in an oven with an air atmosphere. The $\mathrm{UO}_{2}$ was totally converted to $\mathrm{U}_{3} \mathrm{O}_{8}$ after standing overnight at 400 to $500{ }^{\circ} \mathrm{C}$. For example, the feed materials for Runs-LK 26,28 and 29 in the LiCl-KCl pilot plant electrolyses had $0 / U$ ratios of 2.664 and 2.668 after such treatment. Temperatures above $600{ }^{\circ} \mathrm{C}$ caused sintering and temperatures below $400{ }^{\circ} \mathrm{C}$ resulted in incomplete conversion of the oxide.

For remote operations, the apparatus shown in Figure 6 was designed to permit oxidation and dumping of the oxide into the salt bath. The objectives of the remote equipment were to couple the oxidizer directly to the decladder, to get enough oxygen to the $\mathrm{UO}_{2}$ to oxidize it in a reasonable time interval without fluidizing the fines out of the bed, to contact all the $\mathrm{UO}_{2}$ with the oxygen, to control the reaction rate to prevent runaway reactions that would cause sintering, to be able to pour out all or part of the oxide, and to minimize radioactive dust in the cell atmosphere.

Typical oxidation runs made during the testing of the equipment with 30-Ib batches of minus 3 mesh fused $\mathrm{UO}_{2}$ powder are shown in Table VI. A 30-1b batch is approximately double the average batch size used in the Salt Cycle Demonstration. (7) Only a partial oxidation was considered sufficient since the primary purpose of the oxidation is not to produce $\mathrm{U}_{3} \mathrm{O}_{8}$, but to break up the $\mathrm{UO}_{2}$ particles. The weight change was used to indicate the approximate degree of oxidation. The least desirable occurrence during oxidation was a temperature excursion above $600{ }^{\circ} \mathrm{C}$ that sintered the oxide and made it difficult to pour. High gas flow rates ( 5 liters/min) fluidized the finely divided product in the oxidizer and reduced the degree of oxidation by cooling the packed bed of $\mathrm{UO}_{2}$, although the inlet gas had been preheated by entering in a line that passed through the bed. Redesign of the container was necessary before the oxide could readily be poured. The final design included a rotating ring about $3-i n$. diam in the throat of the nonsymmetrical taper to break up partially sintered oxide. Appreciable variation in the degree of oxidation throughout the bed was encountered even when all the $\mathrm{UO}_{2}$ feed had been converted to a fine powder. However, since complete oxidation was not required for dissolution, it was not felt necessary to improve the 

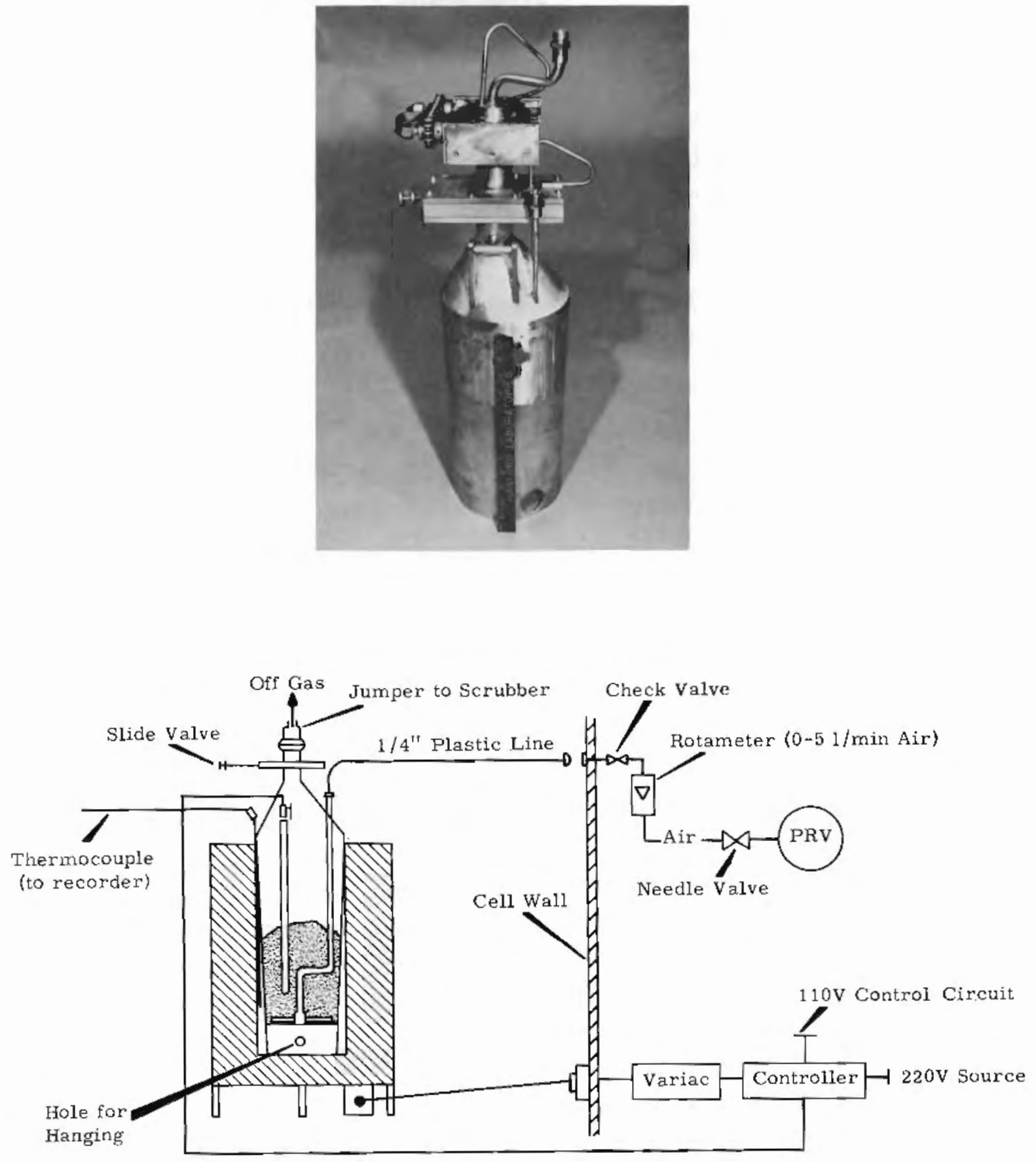

FIGURE 6

Remote Oxidizing Equipment 
IBISVI

OXIDATIOR! OF YO 2 IA PROTOTYPE OXIDATION EQUIPMEIT

Feed laterial: $301 \mathrm{~b}$ of minus 3 mesh arc fused $\mathrm{J} \mathrm{O}_{2}$

\begin{tabular}{|c|c|c|c|c|c|c|c|c|c|c|c|}
\hline \multirow[b]{2}{*}{ Run No, } & \multirow[b]{2}{*}{$\begin{array}{c}\text { Vol\% } \\
\mathrm{O}_{2} \text { in Gas }\end{array}$} & \multicolumn{2}{|c|}{ Gas Fiow } & \multirow[b]{2}{*}{ Temp, ${ }^{\circ} \mathrm{C}$} & \multirow{2}{*}{$\begin{array}{l}\text { Ratio of } \\
\partial_{2} \text { Used to } \\
\text { Stoic. }\end{array}$} & \multirow[b]{2}{*}{$\begin{array}{l}\text { Wt Gain, } \\
1 b \\
\end{array}$} & \multirow[b]{2}{*}{ Final } & \multirow[b]{2}{*}{ O/U Ratio } & \multicolumn{2}{|c|}{ Percent Oxidized } & \multirow[b]{2}{*}{ Comments } \\
\hline & & $\begin{array}{l}\text { Rate, } \\
\ell / \text { min } \\
\end{array}$ & $\begin{array}{l}\text { Time, } \\
\mathrm{hr} \\
\end{array}$ & & & & & & $\begin{array}{l}\text { from } \\
\text { Wt. Gain }\end{array}$ & $\begin{array}{c}\text { from } \\
0 / U \text { Ratio }\end{array}$ & \\
\hline$O X-R I$ & Air & 1.5 & 23.5 & 450 & 1.2 & 1.05 & & -- & 89 & -- & \\
\hline $0 x-1$ & $42-58$ & 1.4 & 23.0 & $350-520$ & 1.9 & 1.2 & 2.664 & & 101 & 99.6 & $\begin{array}{l}\text { Bed volume in- } \\
\text { creased by } \\
230 \% \text {. }\end{array}$ \\
\hline $0 x-2$ & $40-50$ & 1.4 & 21.8 & $330-400$ & 2.2 & 1.1 & & -- & 93 & -- & $\begin{array}{l}\text { No temperature } \\
\text { excursions. }\end{array}$ \\
\hline$D X-3 A$ & $20^{\circ}$ & 2.7 & 21.0 & $400-500$ & 2.3 & 1.0 & & -- & 84 & -- & $\begin{array}{l}\text { Excursions to } \\
675^{\circ} \mathrm{C} \text {. }\end{array}$ \\
\hline $0 x-5$ & Air & 5.0 & 28.3 & $440-480$ & 4.4 & 0.8 & 2.432 & & 67 & 64.8 & $\begin{array}{l}\text { Unoxidized } \mathrm{UO}_{2} \\
\text { presert in the } \\
\text { poured powder. }\end{array}$ \\
\hline $0 x-6$ & Air & 2.5 & 26.8 & 570 & 2.2 & 0.95 & $\begin{array}{l}2.649 \\
2.209\end{array}$ & $\begin{array}{l}\text { High Value* } \\
\text { Low Value* }\end{array}$ & 80 & $\begin{array}{l}97.3 \\
31.3\end{array}$ & $\begin{array}{l}\text { All parts of the } \\
\text { bed apparently } \\
\text { partially oxi- } \\
\text { dized. }\end{array}$ \\
\hline
\end{tabular}

* Several samples taken throughout bed. 
apparatus. The percentage of oxygen in the feed was a compromise between the time necessary to pass a stoichiometric quantity of oxygen through the bed and the ability to control the reaction. A flow rate of 2 liters $/ \mathrm{min}$ of air at $500{ }^{\circ} \mathrm{C}$ for $24 \mathrm{hr}$ for a $15-1 \mathrm{~b}$ batch of oxide feed was finally selected as a compromise for the Salt Cyce demonstration. $(7,14)$

\section{SALT SYSTEM PROPERTIES}

Three salt systems were used in pilot plant operations: $\mathrm{NaCl}-\mathrm{KCl}, \mathrm{PbCl}_{2}-$ $\mathrm{KCl}$, and $\mathrm{LiCl}-\mathrm{KCl}$ 。 Operation at the lowest possible temperature was desired in order to reduce corrosion of metallic parts of the off-gas system by chlorine gas, corrosion of potential metallic candidates for containers and electrodes, and corrosion of graphite electrodes by air or chlorine.

\section{Phase Diagrams}

Phase diagrams of the three salt solvents are shown in Figure 7. (15) The $\mathrm{IaCl}-\mathrm{KCl}$ system has a minimum melting solid solution near equimolar $\mathrm{TaCl}-\mathrm{KCl}$, which melts at about $660^{\circ} \mathrm{C}$. The minimum operating temperature below which freezing problems occurred in the pilot plant was about $700{ }^{\circ} \mathrm{C}$. Although the vapor pressures of $\mathrm{NaCl}$ and $\mathrm{KCl}$ are below 0.1 torr in this region, small quantities of solids were found in the off-gas piping. These solids would have to be removed during extended operating periods. Determination of the liquidus curve by differential thermal analysis for equimolar ITaCl-KCl gave a monotonic decrease in melting point with added $\mathrm{UO}_{2} \mathrm{Cl}_{2}$ from $660{ }^{\circ} \mathrm{C}$ to $490{ }^{\circ} \mathrm{C}$ at $41 \mathrm{~mol}^{\%} \mathrm{UO}_{2} \mathrm{Cl}_{2}{ }^{\circ}{ }^{(16)}$ Measurements at higher uranium concentrations were prevented by the thermal decomposition of $\mathrm{UO}_{2} \mathrm{Cl}_{2}$.

The $\mathrm{KCl}-\mathrm{PbCl}_{2}$ phase diagram is more complex because of compound formation. At the $2.5 \mathrm{KCl}-1 \mathrm{PbCl}_{2}$ mole-ratio composition at which pilot plant operations were conducted to prevent electrodeposition of lead, $\mathrm{KCl}$ freezes out at about $570{ }^{\circ} \mathrm{C}$. Addition of $\mathrm{UO}_{2} \mathrm{Cl}_{2}$ to $2.5 \mathrm{KCl}-1 \mathrm{PbCl}_{2}$ significantly lowers the freezing point as is shown in Figure 3. (16) A concentration of $30 \mathrm{wt} \%$ $\mathrm{UO}_{2} \mathrm{Cl}_{2}$, which was achieved in pilot plant runs, lowers the melting point to $415{ }^{\circ} \mathrm{C}$, but electrolyzing out the uranium again raises the melting point so that the pure solvent composition controls the operating temperature. Pilot 

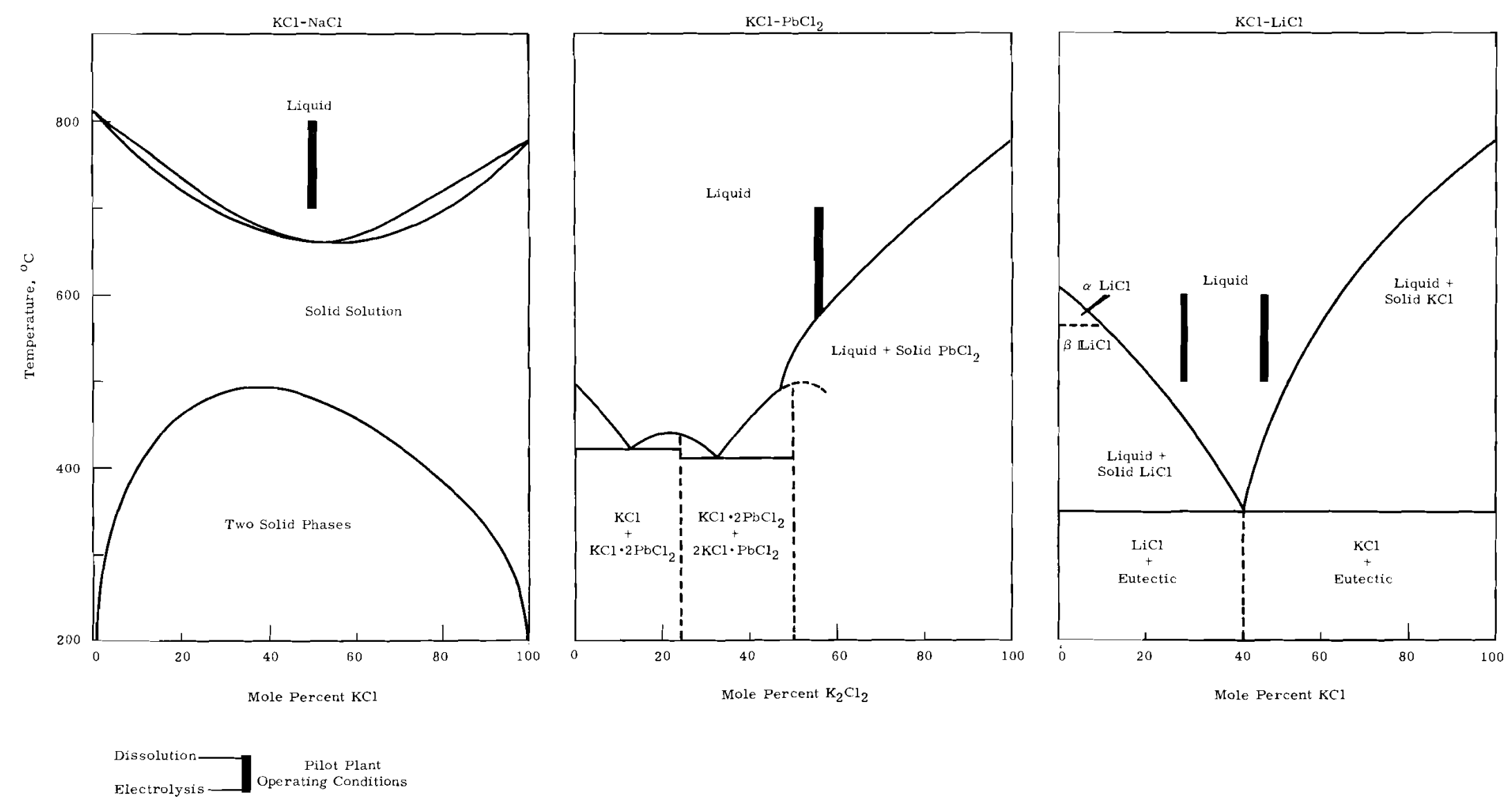

FIGURE 7

Phase Diagrams of Molten Salt Solvents 


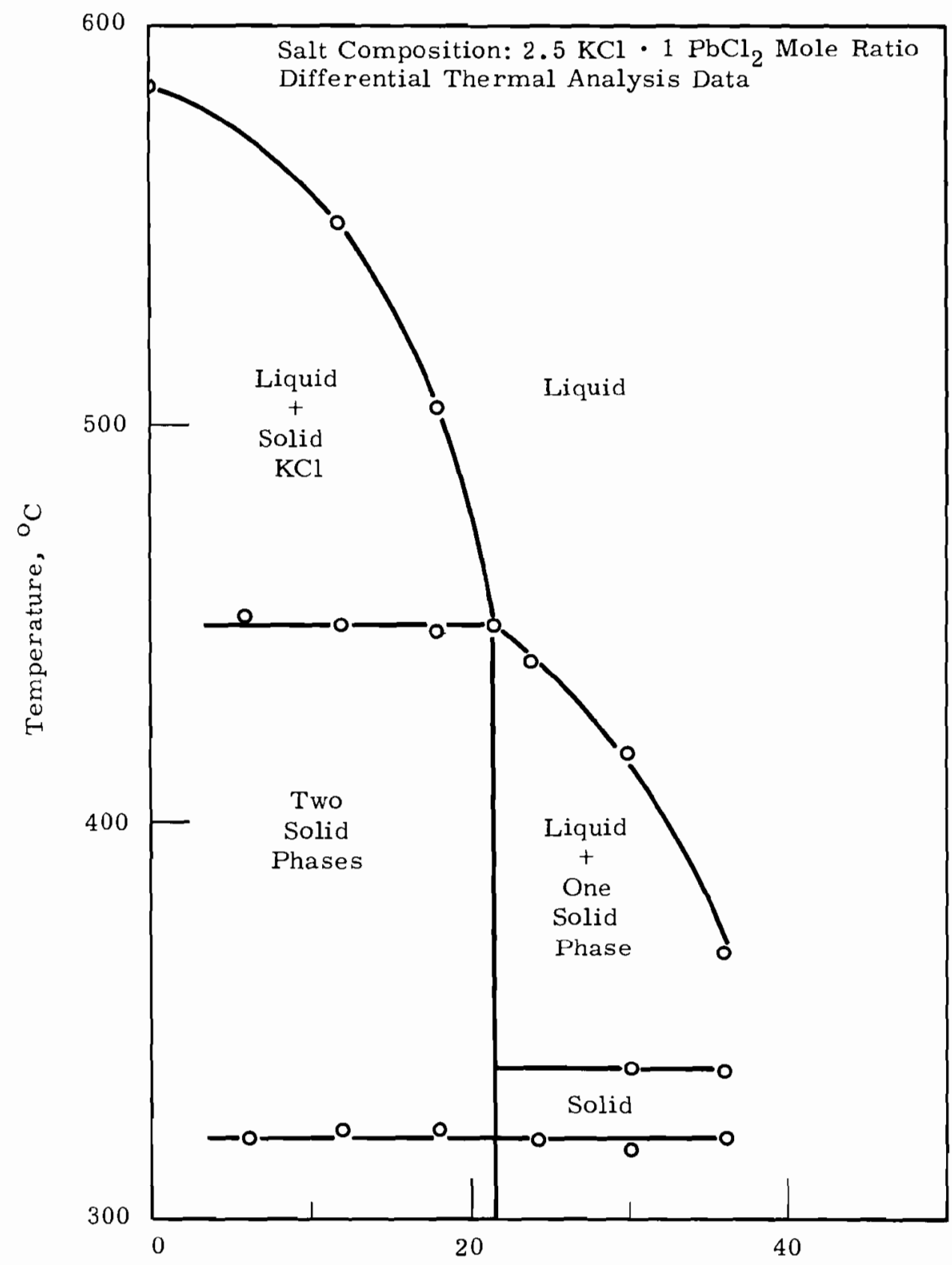

Weight Percent $\mathrm{UO}_{2} \mathrm{Cl}_{2}$

FIGURE 8

Phase Diagram for $\mathrm{KCl}-\mathrm{PbCl}_{2}-\mathrm{UO}_{2} \mathrm{Cl}_{2}$ 
plant electrolyses were conducted at $600^{\circ} \mathrm{C}$ and uranium oxide dissolutions as high as $700^{\circ} \mathrm{C}$. The vapor pressure of $\mathrm{PbCl}_{2}$ is $0.1-1.0$ torr in this region, and plugging of the $4-i n$. off-gas line with $\mathrm{PbCl}_{2}$ dust occurred frequently during extended pilot plant runs.

The LiCl-KCl system forms a simple eutectic at $40 \mathrm{~mol} \%$ LiCl that melts at $340^{\circ} \mathrm{C}$. Operations with this system were conducted with a solvent of $53 \mathrm{~mol} \% \mathrm{LiCl}$ for codeposition and $72 \mathrm{~mol} \% \mathrm{LiCl}$ for partition of $\mathrm{UO}_{2}$ from $\mathrm{Pu}$ (III). The addition of $\mathrm{UO}_{2} \mathrm{Cl}_{2}$ first decreases and then increases the melting point as is shown in Figure $90(16)$ The operating range of 500 to $600{ }^{\circ} \mathrm{C}$ was determined not by the melting point of the salts but by the achievement of practical rates of dissolution of $\mathrm{U}_{3} \mathrm{O}_{8}$ and current densities during electrolysis governed by the resistance of the salt bath. The hygroscopic nature of $\mathrm{LiCl}$ required that it be kept sealed or in a dry atmosphere at all times when at room temperature. Reduction of the relative humidity from the normal $35 \%$ to $10 \%$ was often enough to reduce moisture pickup to acceptable levels for handling frozen salt.

Densities of Molten Salts

The density of the molten salt is useful in sizing equipment and in determining the uranium content. Densities of $\mathrm{PbCl}_{2}-2.5 \mathrm{KCl}$ (the only system for which appreciable data are available) with added $\mathrm{UO}_{2} \mathrm{Cl}_{2}$ are shown in Figure 10 as a function of temperature. (17) The $\mathrm{PbCl}_{2}-2.5 \mathrm{KCl}$ is not a sensitive system for uranium concentration measurement because of the high density of lead. The equimolar LiCl-KCl system, which varies in density from 1.6 to $2.1 \mathrm{~g} / \mathrm{cm}^{3}$ as the uranium content is increased from 0 to $10 \mathrm{wt} \%$, was suitable for such measurement.

Electrical Conductivity of $\mathrm{UO}_{2}$

The electrical conductivity of a sample of electrolytic $\mathrm{UO}_{2}$ deposited from equimolar $\mathrm{NaCl}-\mathrm{KCl}$ at $700^{\circ} \mathrm{C}$ was measured by Battelle Memorial Institute (Columbus) using techniques reported in BMI-1135. (18) The electrical conductivities shown in Figure 11 were measured on the first heatup of a sample $\mathrm{UO}_{2}$ having an $0 / U$ ratio of 2.015 . Presumably, the phase present is $\mathrm{UO}_{2+\mathrm{x}}$ and in the low temperature region it behaves as a metal-deficient, or oxygen-rich 


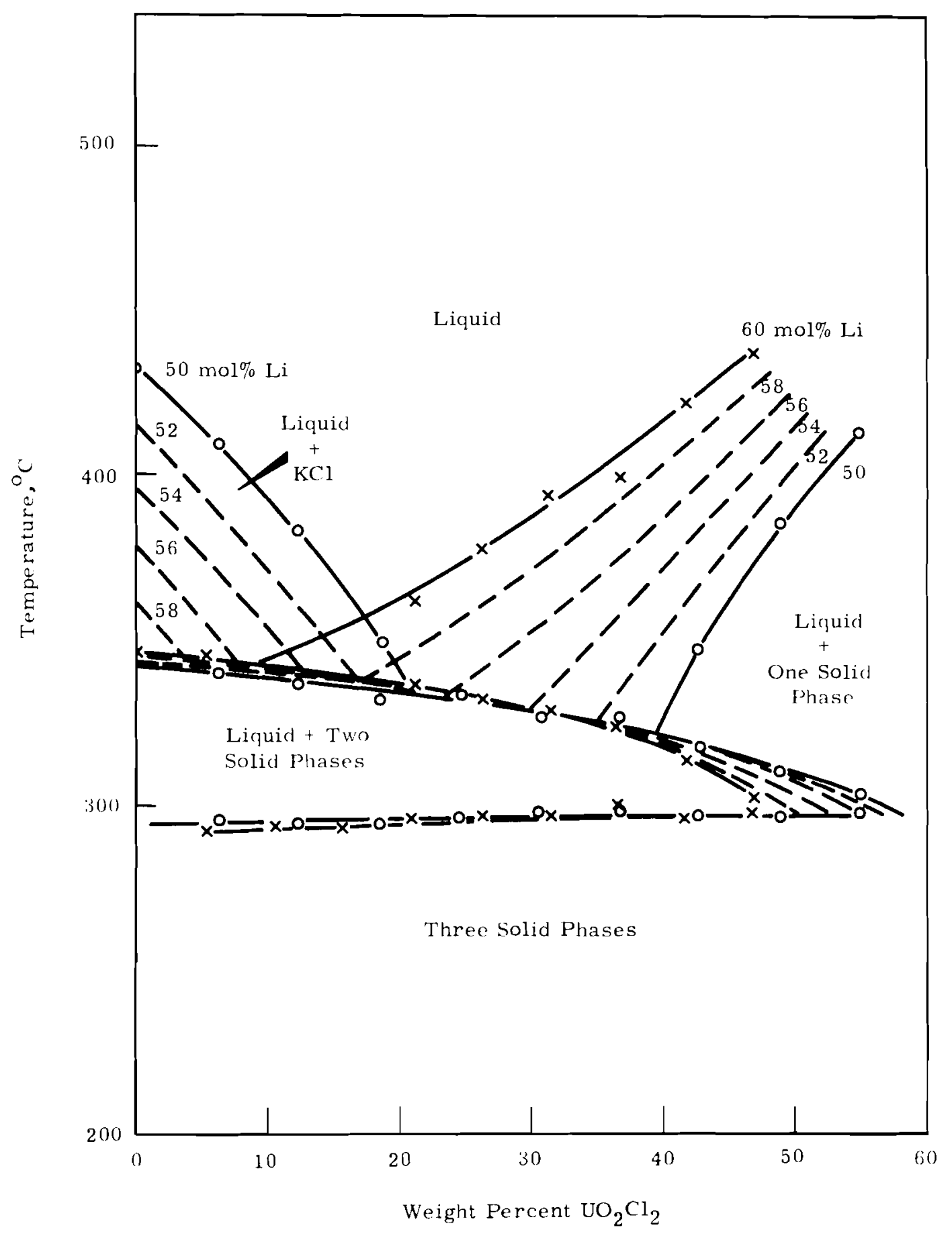

FIGURE 9

Phase Diagram for $\mathrm{KCl}-\mathrm{LiCl}-\mathrm{UO}_{2} \mathrm{Cl}_{2}$ 


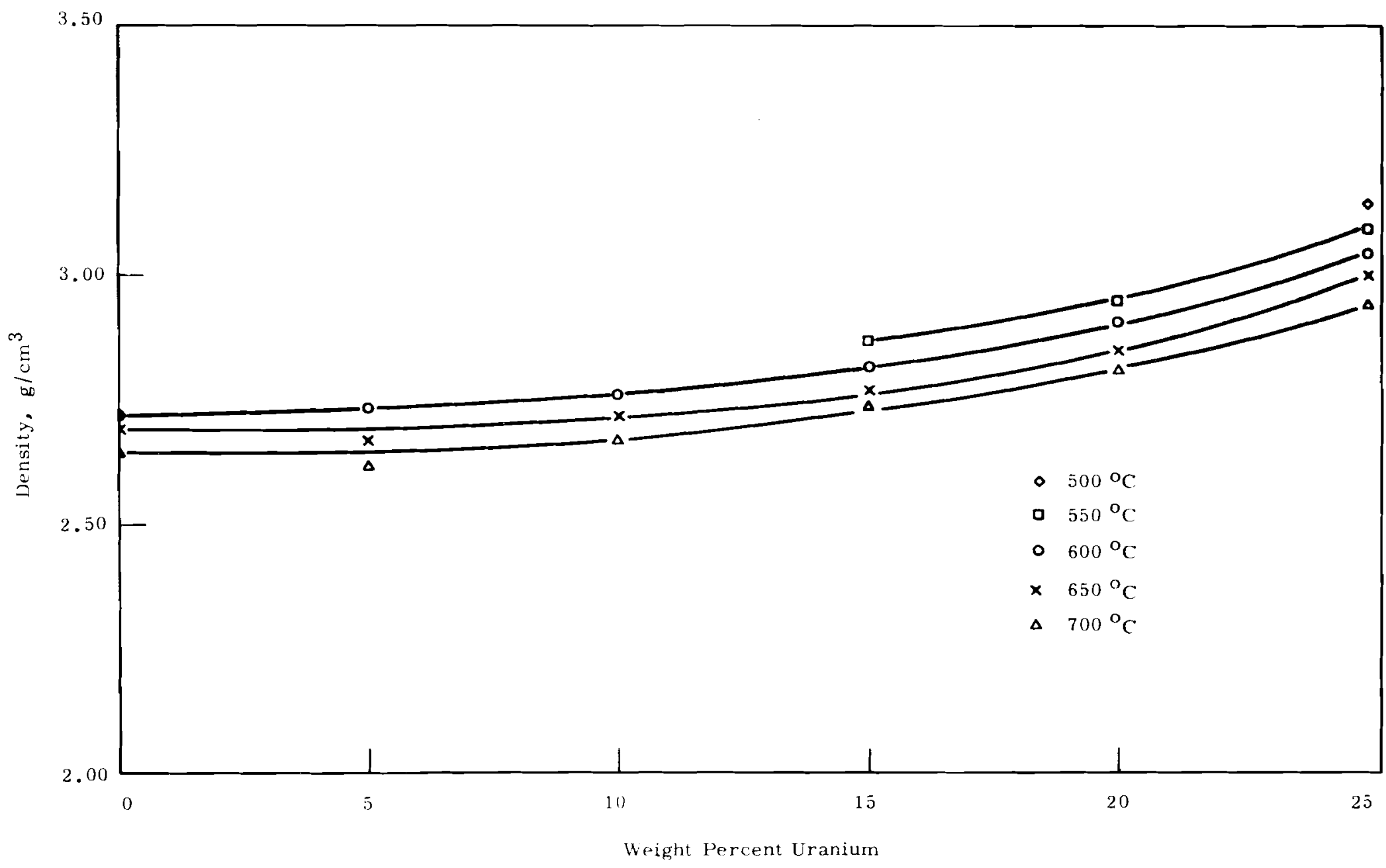

FIGURE 10

Density of $\mathrm{PbCl}_{2}-2.5 \mathrm{KCl}$ with Added $\mathrm{UO}_{2} \mathrm{Cl}_{2}$ 


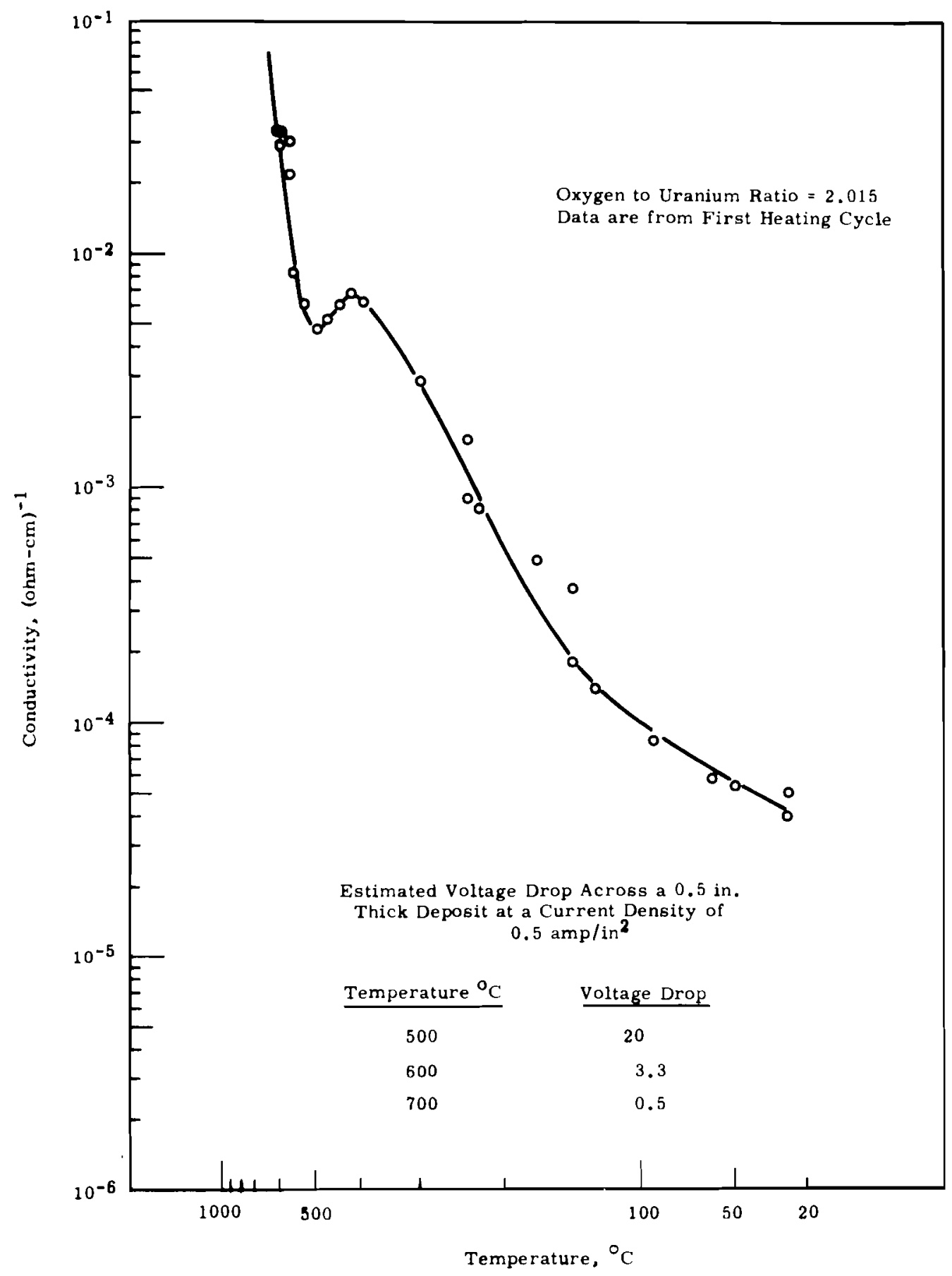

FIGURE 11

Electrical Conductivity of Electrolytic $\mathrm{UO}_{2}$ Deposited from Equimolar $\mathrm{NaCl}-\mathrm{KCl}$ at $700{ }^{\circ} \mathrm{C}$ 
semiconductor with a transition to electronic conduction at 500 to $600{ }^{\circ} \mathrm{C}$ 。 In BMI-1135 the electrical conductivity of $\mathrm{UO}_{2}$ is shown to vary widely with the crystal structure and the thermal history and to decrease rapidly as the $0 / \mathrm{U}$ ratio approaches 2. The conductivity of electrolytic $\mathrm{UO}_{2}$ is comparable with that of the sintered $\mathrm{UO}_{2}$ discussed in that report and of single crystals of $\mathrm{UO}_{2^{\circ}}$ (19)

Very high voltage drops across the deposit were calculated from data presented in Figure 11 for a 0.5-ino-thick deposit with a current density of $0.5 \mathrm{mp} / \mathrm{in}^{2}$, typical conditions during pilot plant runs. Nlthough the voltage drop is only $0.5 \mathrm{~V}$ at $700^{\circ} \mathrm{C}$ at which the deposit was produced, voltage drops of $3.3 \mathrm{~V}$ at $600{ }^{\circ} \mathrm{C}$ and $20 \mathrm{~V}$ at $500{ }^{\circ} \mathrm{C}$ were estimated。 However, the actual experience with pilot plant electrolyses that produced dense sheets of $\mathrm{UO}_{2}$ at 550 to $600^{\circ} \mathrm{C}$ indicated the drop across the deposit was only a very minor part of the total cell resistance, being at most only a few tenths of a volt. This apparent inconsistency can only be resolved by comparison measurements of resistances of $\mathrm{UO}_{2}$ in salt baths and of products from the $\mathrm{LiCl}-\mathrm{KCl}$ and $\mathrm{PbCl}_{2}-\mathrm{KCl}$ systems. Attempts to further lower the operating temperatures of the Salt Cycle process may run into the problem of high deposit resistances, which could result in deterioration of crystal structure and a practical limit on obtainable deposit thickness. Decomposition Potentials of $\mathrm{UO}_{2} \mathrm{Cl}_{2}$ and Salt Solvents

In the alkali chloride solvents, the salt decomposition potentials are well above $2 \mathrm{~V}$, so that high current densities in the deposition of $\mathrm{UO}_{2}$ can easily be obtained without alkali metal deposition. In the $\mathrm{PbCl}_{2}-\mathrm{KCl}$ system, however, the codeposition of lead is a major problem. In order to eliminate the variable voltage drops at the anode, caused by the chlorine liberation that changes with current density, all potentials are measured with $\mathrm{Ag} / \mathrm{l}$ molal $\mathrm{AgCl}$ in $\mathrm{PbCl}_{2}-2 \mathrm{KCl}$ as the other half cello The potential of such cells is shown in Figure 12 for lead in $\mathrm{PbCl}_{2}-\mathrm{KCl}$ mixtures and for 10 mol\% $\mathrm{UO}_{2} \mathrm{Cl}_{2}$ in $\mathrm{PbCl}_{2}-\mathrm{KCl}$. mixtures. The gap between the $\mathrm{UO}_{2}{ }^{++}$and $\mathrm{Pb}^{++}$reduction curves and the $\mathrm{Pb}^{++}$allows operation at relatively high current densities if close control is maintained. The cell potentials are relatively weak functions of the salt composition and the operating temperature. 


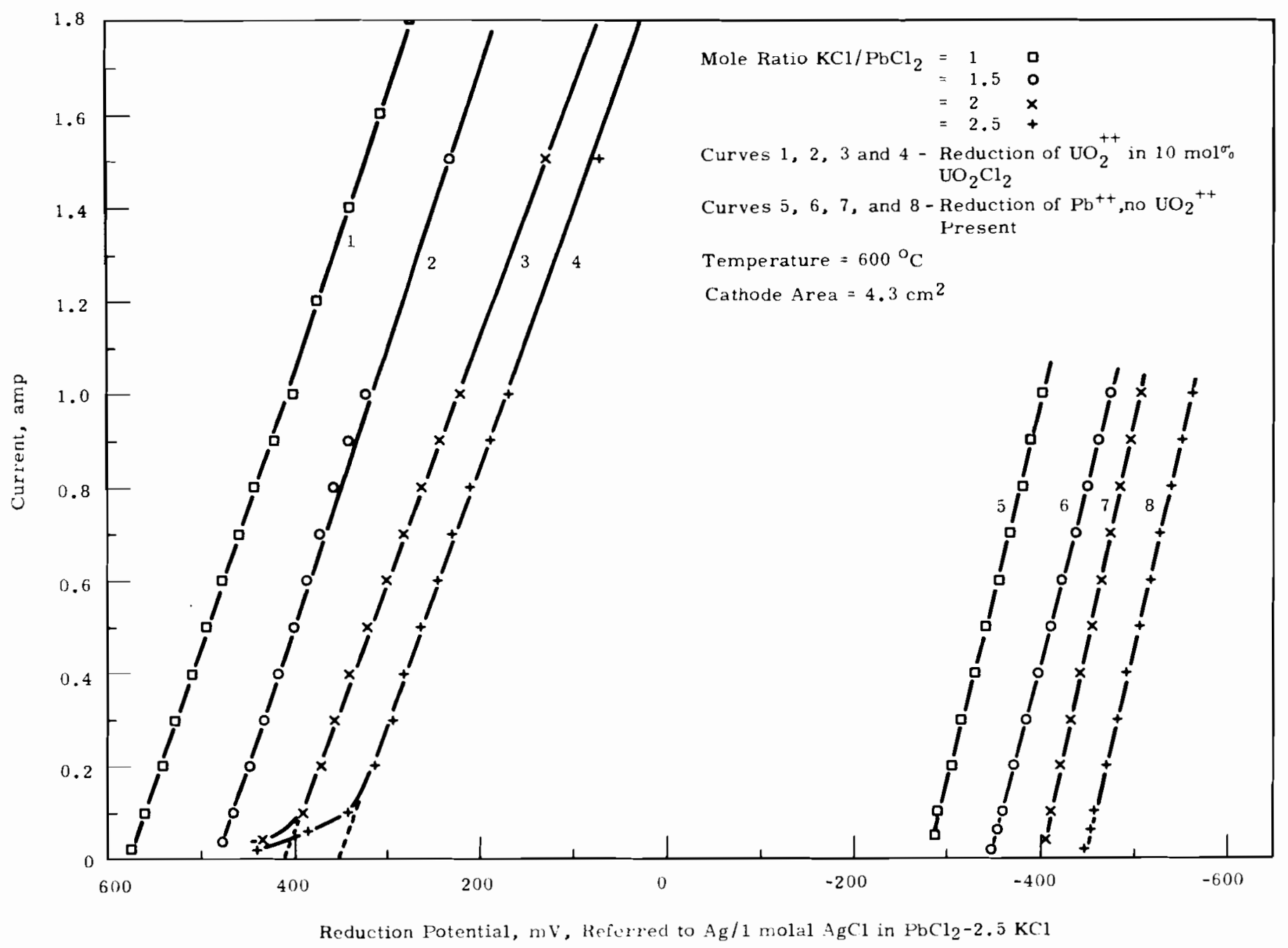

FIGURE 12

Decomposition Potentials in $\mathrm{PbCl}_{2}-\mathrm{KCl}-\mathrm{UO}_{2} \mathrm{Cl}_{2}$ System 
SODIUM CHLORIDE-POTASSIUM CHLORIDE PILOT PLANT OPERATIONS

Pilot plant electrolyses in the $\mathrm{NaCl}-\mathrm{KCl}$ system were conducted in a fused silica crucible containing about 20 liters of molten salt. The salt was heated in a $13 \mathrm{~kW}$ Trent* furnace with Nichrome ${ }^{B}$ heating elements. The apparatus is illustrated in Figure 13. Reactor-grade graphite electrodes were used throughout. The preferred electrode orientation was two anodes with one cathode in the center. The off-gas system consisted of a Transite (B) cover with a side arm discharging to a caustic scrubber. Equimolar $\mathrm{NaCl}-\mathrm{KCl}$ was used as the solvent in all runs. The minimum operating temperature was $700^{\circ} \mathrm{C}$ because of the high $\left(650^{\circ} \mathrm{C}\right)$ melting point of the solvent. A chlorine blanket over the melt was relied upon to keep air from the melt and there was no special attempt to exclude air from the vapor space. The major purposes of this series of runs were to produce 100 pounds of electrolytic $\mathrm{UO}_{2}$ for evaluation by the Ceramic Fuels Development Operation and to determine the problems involved in operating the molten salt system in equipment suitable for large scale operation. Dissolution and Drying

Because prolonged sparging of the molten salt with chlorine was believed to be necessary to totally dissolve uranium oxides and efficient gas sparging equipment had not yet been developed, uranyl chloride monohydrate $\left(\mathrm{UO}_{2} \mathrm{Cl}_{2} \cdot \mathrm{H}_{2} \mathrm{O}\right)$ was selected as a starting material since it would readily dissolve and would require a minimum of gas sparging for drying. Cormercially available $\mathrm{UO}_{2} \mathrm{Cl}_{2}$. $\mathrm{H}_{2} \mathrm{O}$ was introduced into equimolar $\mathrm{NaCl}-\mathrm{KCl}$ at $700^{\circ} \mathrm{C}$. Water evolved from the system, accompanied by splattering and bubbling. Nevertheless, about one pound of $\mathrm{UO}_{2} \mathrm{Cl}_{2} \cdot \mathrm{H}_{2} \mathrm{O}$ could safely be added per minute at a continuous rate of addition. Evolved hydrogen chloride from the decomposition was detected both by odor and by the presence of an acid in the off-gas. Subsequent analysis of samples of the frozen salt with Karl Fischer reagent indicated that as much as 0.75 moles of water per mole of $\mathrm{UO}_{2} \mathrm{Cl}_{2}$ was still present in the salt at $700^{\circ} \mathrm{C}$. Improvements in moisture control during sampling reduced

* Trent, Inc., Philadelphia, Pa.

(B) Driver-Harris Company

(B) Johns-Manville Company 


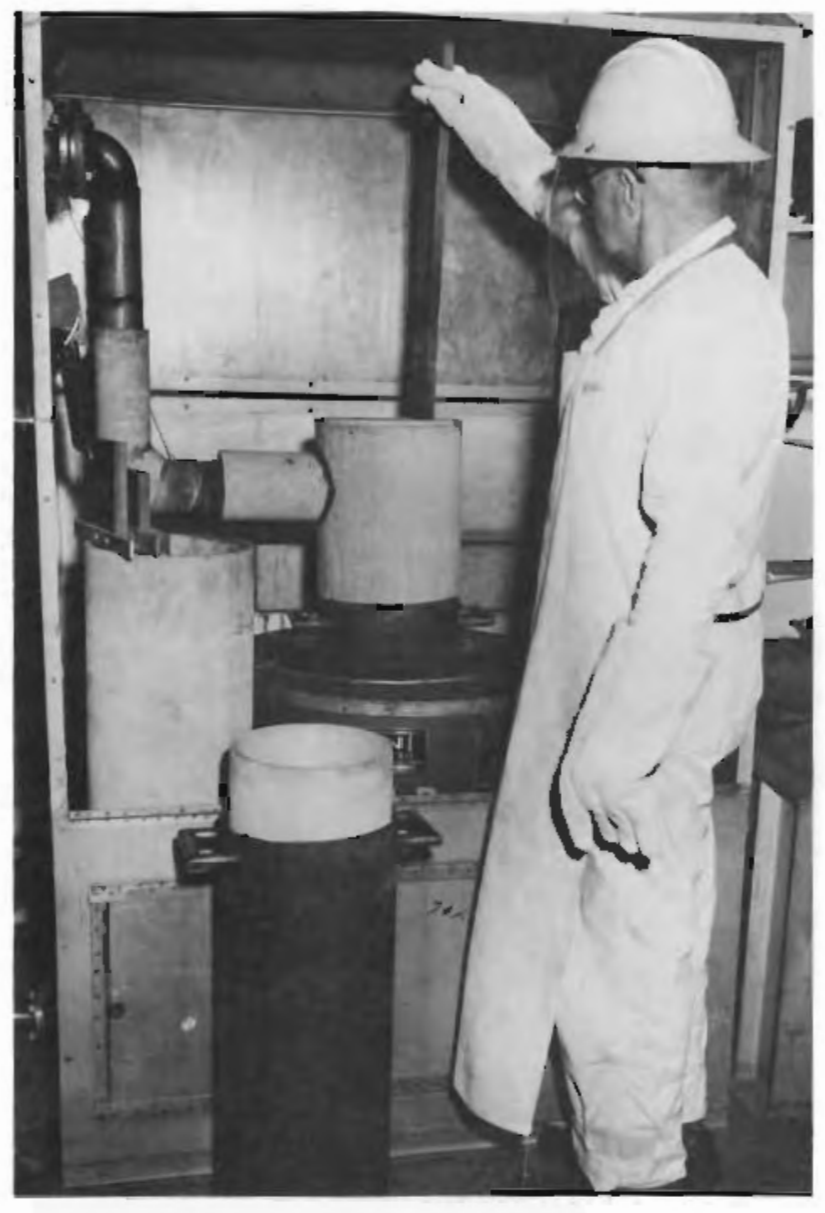

Salt Bath Assembly

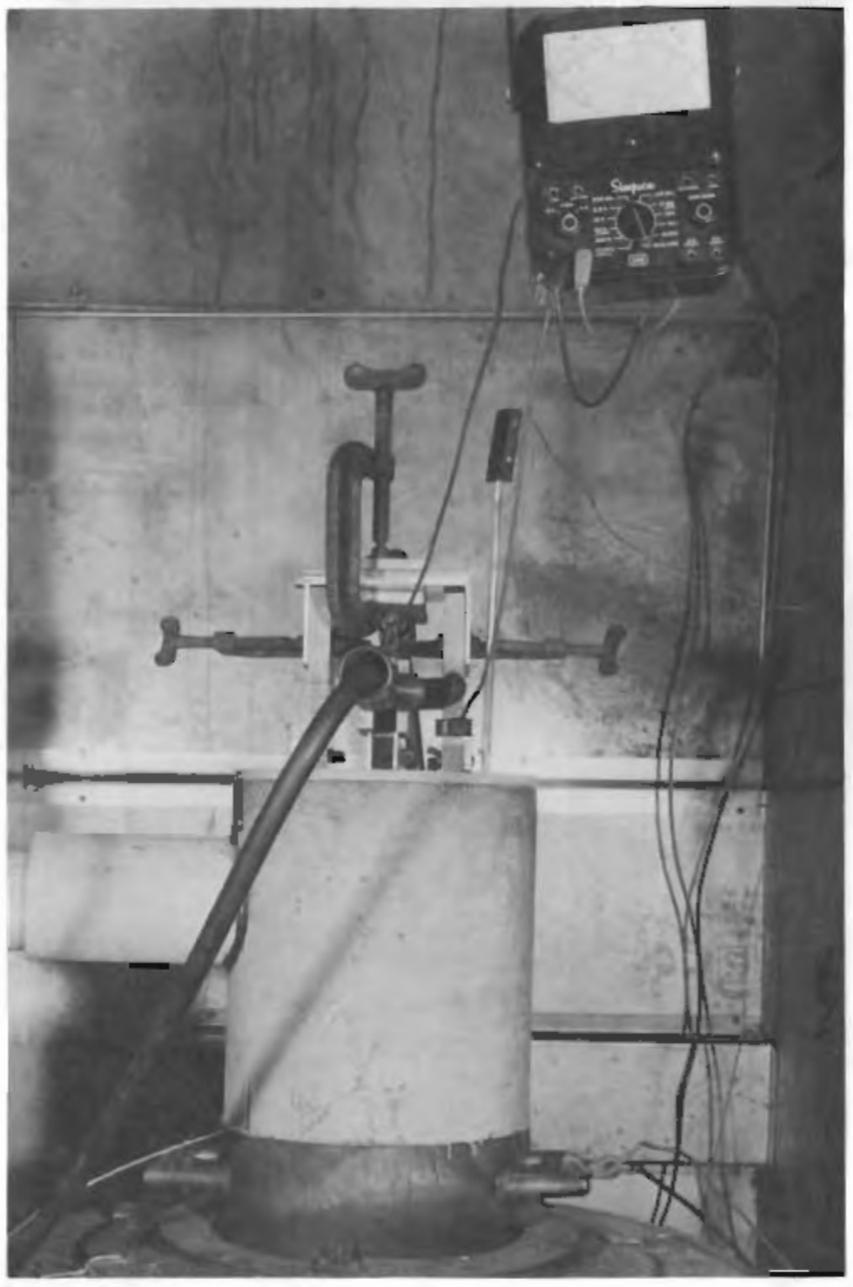

Electrolysis Apparatus

FIGURE 13

Pilot Plant Equipment for Production of Electrolytic $\mathrm{UO}_{2}$ in Equimolar $\mathrm{NaCl}-\mathrm{KCl}$ 
the indicated moisture in the sample but showed that at least a third of the water in the monohydrate is still present in some form in the molten salt bath. This result emphasizes the difficulty in removing moisture from molten salt baths. It is unlikely that the water is present in these systems in its uncombined molecular form. It is probably present in hydrolyzed uranium species such as $\mathrm{UO}_{2}(\mathrm{OH}) \mathrm{Cl}$ or $\mathrm{H}_{2} \mathrm{U}_{2} \mathrm{O}_{7}$. Direct electrolysis of the salt bath with reactor-grade electrodes at $700^{\circ} \mathrm{C}$ gave oxygen-to-uranium ratios of about 2.2. The high $\mathrm{O} / \mathrm{U}$ ratio may have resulted from the reduction of $\mathrm{UO}_{2} \mathrm{Cl}$, $\mathrm{U}_{3} \mathrm{O}_{8} \mathrm{Cl}$, or hydrolyzed uranium species to $\mathrm{U}_{2} \mathrm{O}_{5}, \mathrm{U}_{3} \mathrm{O}_{3}$, and $\mathrm{U}_{4} \mathrm{O}_{9}$, producing a nonstoichiometric $\mathrm{UO}_{2}$ deposit. The thermal decomposition of $\mathrm{UO}_{2} \mathrm{Cl}_{2}$ to $\mathrm{U}_{3} \mathrm{O}_{8}$ on the cathode may also have been a contributing factor.

\section{Electrolysis}

Three pilot plant runs are summarized in Table VII, Drying of the bath with chlorine gas reduced the product oxygen-to-uranium ratio below 2.02 . Each electrolysis was accompanied by the buildup of U(IV) produced by both the reaction of $U(V I)$ with the carbon anodes and chlorine gas, and the redissolution of $\mathrm{UO}_{2}$ by chlorine at the cathode. The latter reaction is shown by the reduced current efficiency calculated from the weight of the product $\mathrm{UO}_{2}$. It probably contributed significantly to the reduction of the O/U ratio of the product, Because U(IV) will not deposit at the cathode, it was allowed to oxidize' by standing in air overnight. The uranium content of the bath was not raised above $10 \mathrm{wt}$; because of the fear that thermal decomposition of $\mathrm{UO}_{2} \mathrm{Cl}_{2}$ might increase the $\mathrm{O} / \mathrm{U}$ ratio of the product. This possibility was never quantitatively defined, although thermal decomposition to $\mathrm{U}_{3} \mathrm{O}_{8}$ had previously limited phase diagram determinations in this system to low uranium concentrations. (16) An attempt at removal of the last bit of uranium from the bath immediately following the second run resulted in a high $0 / U$ ratio in the product (probably from air inleakage) and an increased current efficiency because of the decreased chlorine production at the anode. Dual Vessel Experiments

A combination of two induction-heated 20 -liter fused silica vessels was employed in experiments to increase the capacity of the system. The experiments are summarized in Table VII。 Twenty pounds of $\mathrm{UO}_{3}$ were dissolved 


\section{TABLE VII}

PILOT PLANT ELECTROLYSES

Equimolar $\mathrm{NaCl}$ - KCl Salt System

Container: 20 liter, 9 inch diam fused silica crucible

Approximate Salt Weight: 65 lb

Feed Material: $\mathrm{VO}_{2} \mathrm{Cl}_{2} \cdot \mathrm{H}_{2} \mathrm{O}$

Electrode Material: Reactor Grade Graphite,

$3 / 4$ inch $\times 4$ inch $\times 17$ inch length submerged in salt

\begin{tabular}{|c|c|c|c|c|c|c|c|c|c|c|c|c|c|c|}
\hline \multirow[b]{2}{*}{ Run No. } & \multicolumn{2}{|c|}{ CHLORINE GAS DRYING } & \multicolumn{3}{|c|}{ WT URANTUM } & \multirow[b]{2}{*}{$\underline{\operatorname{Temp}},{ }^{\circ} \mathrm{C}$} & \multirow[b]{2}{*}{$\begin{array}{l}\text { Time, } \\
\mathrm{hr}\end{array}$} & \multirow[b]{2}{*}{$\begin{array}{c}\text { Cell } \\
\text { Voltage, }\end{array}$} & \multicolumn{2}{|c|}{ ELECTROLYSIS } & \multirow[b]{2}{*}{$\begin{array}{c}\text { Current } \\
\text { Erficiency }\end{array}$} & \multirow[b]{2}{*}{$\begin{array}{l}\text { Number } \\
\text { of Anodes }\end{array}$} & \multicolumn{2}{|c|}{ PRODUCT } \\
\hline & Rate, $\ell / \min$ & Time, $\mathrm{hr}$ & $\begin{array}{c}\text { Before } \\
\text { Electrolysis } \\
\end{array}$ & $\begin{array}{r}\text { Art } \\
\text { Electr } \\
\text { U Total } \\
\end{array}$ & $\begin{array}{l}r \\
\frac{\text { lysis }}{U(I V)} \\
\underline{U(\text { IV }}\end{array}$ & & & & $\frac{\text { Current Density }}{\text { Initial }}$ & $\frac{\operatorname{amp} / \text { in }^{2}}{\text { Final }}$ & & & $\begin{array}{c}\text { oxygen-to } \\
\text { Jranium Ratio }\end{array}$ & $\begin{array}{c}\text { Carbon } \\
\text { Content, ppm } \\
\end{array}$ \\
\hline NPL-1 & 1.82 to 0.65 & 3.9 & 9.9 & 6.8 & 1.2 & $730-735$ & 2.8 & 1.70 & 3.24 & 2.06 & 67.2 & 1 & $2.01 ?$ & 1800 \\
\hline NPL-2 & 1.82 & 1.5 & $6.6^{*}$ & 3.1 & 0.7 & $730-735$ & 4.0 & 1.40 & 1.85 & 1.11 & 66.1 & 1 & 2.019 & 590 \\
\hline NPL -3 & --- & 0 & $3.1^{*}$ & $(1.2)$ & ---- & $735-740$ & 5.0 & $1.0 \mathrm{~B}$ & 1.39 & 0.56 & 79.0 & 2 & 2.073 & $1, A_{0}$ \\
\hline \multicolumn{15}{|c|}{ Dusl Vessel Experiments } \\
\hline NPL -1 & Intermittent & Mixing, Se & Figure $17 * *$ & & & $7 n 0-715$ & --- & 1.55 & $2.7^{\circ}$ & $1.3 n$ & $65 . ?$ & 2 & 2.011 & 3230 \\
\hline PPL-5 & Continuous $\mathrm{Mi}$ & xing, see $F$ & ipure $18 \cdots *$ & & & $7 n 5$ & -.-- & $1 . f+1$ & 3.26 & 1.30 & 66.0 & 2 & 2.106 & 640 \\
\hline
\end{tabular}

* Destroyed U(IV) from previous run by allowing to stand ovemight.

"*?O $\mathrm{Ib} \mathrm{VO}_{3}$ feed dissolved in each crucible. 
in each vessel, and the electrolysis was conducted in one vessel until the bath was depleted in uranium as shown in Figure 14. The vessels were connected by two 3/4-in。-diam uninsulated quartz gas lifts。 Chlorine gas at 2.5 liters/ min was introduced in the gas lift discharging to the electrolysis cell and air at 2.5 liters/min was introduced into the gas lift moving salt from the electrolysis cell to the other vessel. The salt was recirculated between the vessels for $20 \mathrm{~min}$. The electrolysis was then restarted with the same cathode as used before. A deposit with an $O / U$ ratio of 2.011 and with about twice the weight of the average single vessel run was produced The successful mechanical operation of the gas lift without freezing of the salt and with automatic self-regulation of the liquid levels in each vessel indicated the feasibility of producing large deposits of $\mathrm{UO}_{2}$ by dissolving oxide or destroying $U(I V)$ in one vessel and electrolyzing in the other with intermittent recirculation of the salt.

A second experiment to demonstrate continuous recirculation is shown in Table VII and Figure 15. The insertion of the cold electrodes into the bath lowered the temperature appreciably in the electrolysis cell. Consequently the degree of mixing during recirculation could be followed by the temperatures of the two baths. Electrolysis and recirculation were conducted simultaneously with identical gas lift operation as in the preceding run. A small quantity of $\mathrm{UO}_{3}$ was purposely left in the second vessel to simulate continuous dissolution and recirculation. The high $0 / U$ ratio of 201 for the product indicates that the presence of undissolved $\mathrm{UO}_{3}$ or $\mathrm{U}_{3} \mathrm{O}_{8}$ in the bath prevents the electrodeposition of stoichiometric $\mathrm{UO}_{2}$ and that a two vessel dissolver-electrolysis system cannot be operated with simple continuous recirculation. The possibility of dissolving $\mathrm{UO}_{2}$ directly in such a system still exists. However a filter in the gas lift would be necessary to keep $\mathrm{UO}_{2}$ from settling into the electrolysis cell.

\section{Evaluation of Electrolytic UO 2 Product}

About $120 \mathrm{Ib}$ of $\mathrm{UO}_{2}$ was produced in 35 runs in the $\mathrm{NaCl}-\mathrm{KCl}$ salt batin shown in Figure 13. The deposit characteristics were relatively uniform along the electrode except at the surface of the melt, where the deposit tended to be more porous, contained more impurities and had a higher oxygen-to-uranium ratio. 


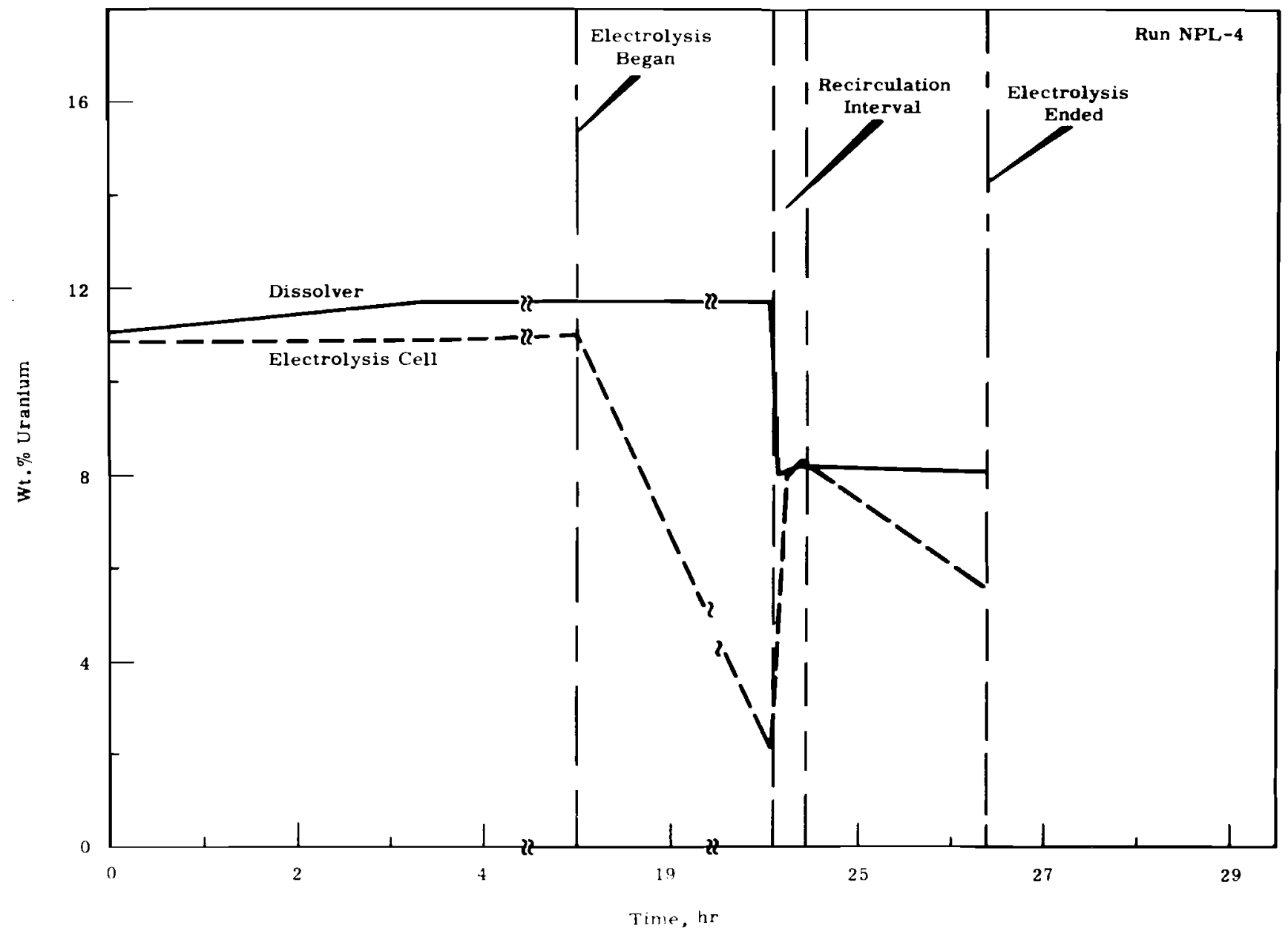

5

FIGURE 14

Electrolysis with Intermittent Recirculation

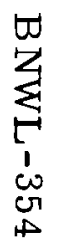



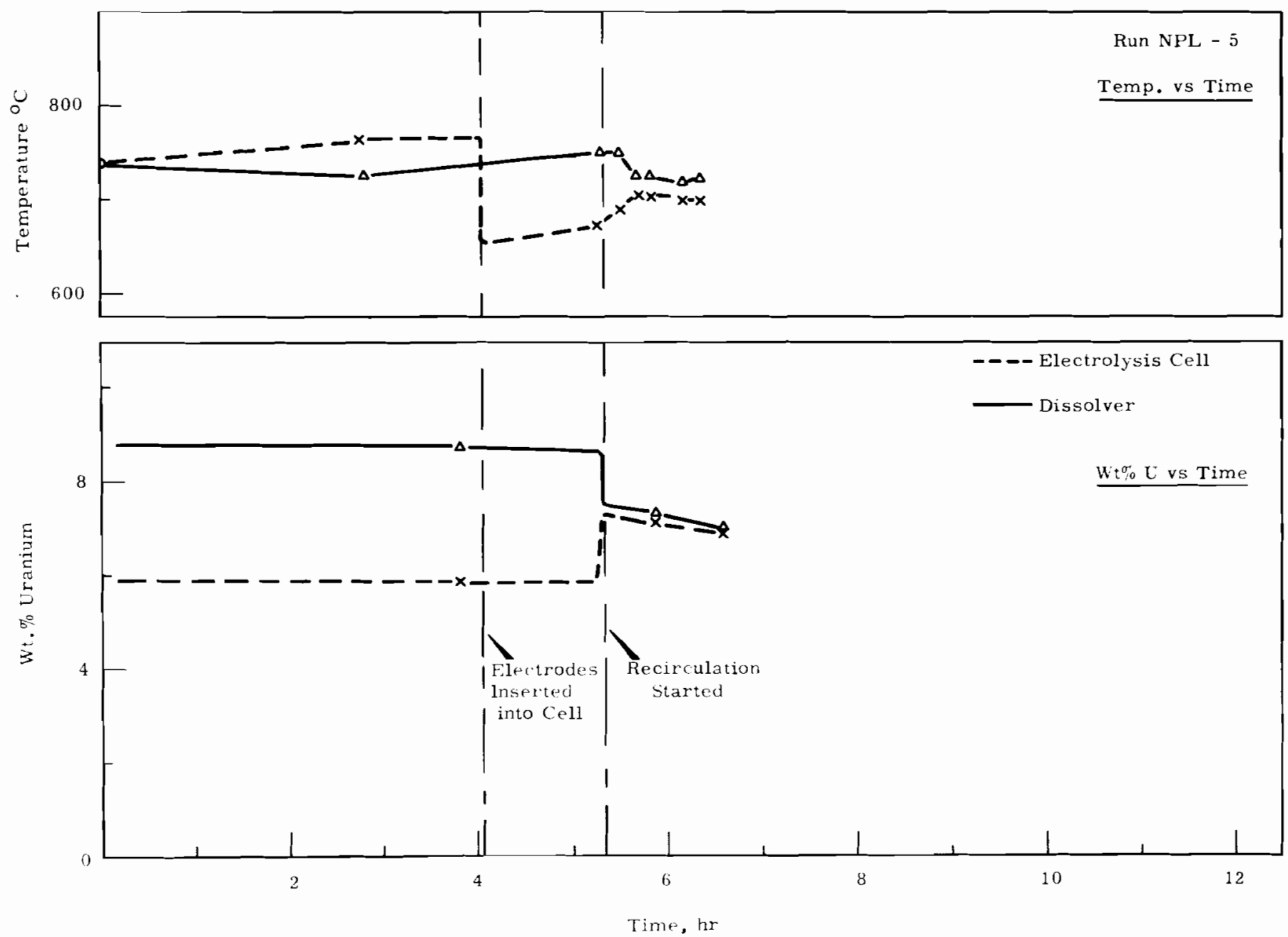

FIGURE 15

Electrolysis with Continuous Recirculation 
As shown in Figure 16, the crystal structure varied significantly from the inside of the deposit to the outside with the largest crystals being the last produced. The carbon content was highest next to the electrode, probably because of breaking away of graphite from the electrode during deposit removal.

A comparison of the particle size distribution of the washed and sieved products is shown in. Figure 17. The cohesiveness of the deposit varied with the $O / U$ ratio and the batch size of the run; high $0 / U$ ratios and thin deposits caused small, single crystals while low $O / U$ ratios and thick deposits broke up with difficulty, and then only into large agglomerates。

The screen fractions for the primary and agglomerated particles of low $\mathrm{U} / 0$ ratio deposits are shown in Figures $18 \mathrm{a}$ and $18 \mathrm{~b}$. These correspond to the two peaks in the particle size distribution shown in Figure 17. The product with high $O / U$ ratios varied widely, ranging from the small, needle-like noncohesive crystals shown in Figure $18 \mathrm{c}$ that are not suitable for fuel element fabrication to the large, well-formed crystals shown in Figure 18d that could be hydrogen-reduced to produce large, dense fuel particles. The more cohesive deposits were probably produced when there was some redissolution of $\mathrm{UO}_{2}$ during electrolysis, which kept a smooth crystal face that continu= ously grew thicker rather than producing single crystals with void formation between them。

The results of laboratory analyses of the product are shown in Table VIII, which is based on 32 electrolysis runs. The specifications listed

\section{TABLE VIII}

CHEMICAL ANALYSES OF ELECTROLYTIC UO 2 PRODUCED

FROM THE NaCl-KCl SYSTEM

$\begin{array}{lcccccc} & \begin{array}{c}0 / \mathrm{U} \\ \text { Ratio }\end{array} & \begin{array}{c}\text { Carbon } \\ \text { ppm }\end{array} & \begin{array}{c}\text { Chlorine } \\ \text { ppm }\end{array} & \begin{array}{c}\text { Sodium } \\ \text { ppm }\end{array} & \begin{array}{c}\text { Potassium } \\ \text { ppm }\end{array} \\ & 2.016 & 1290 & 40 & 130 & 98 \\ \text { Specifications } & <2.02 & <100 & <100 & <100 & <100\end{array}$

are those for $\mathrm{UO}_{2}$ for PRTR fuels。 $(20,21)$ only the median values are reported here because of the wide variation in results caused by nonrepresentative 
Oxygen to Uranium Ratio $=2,015$

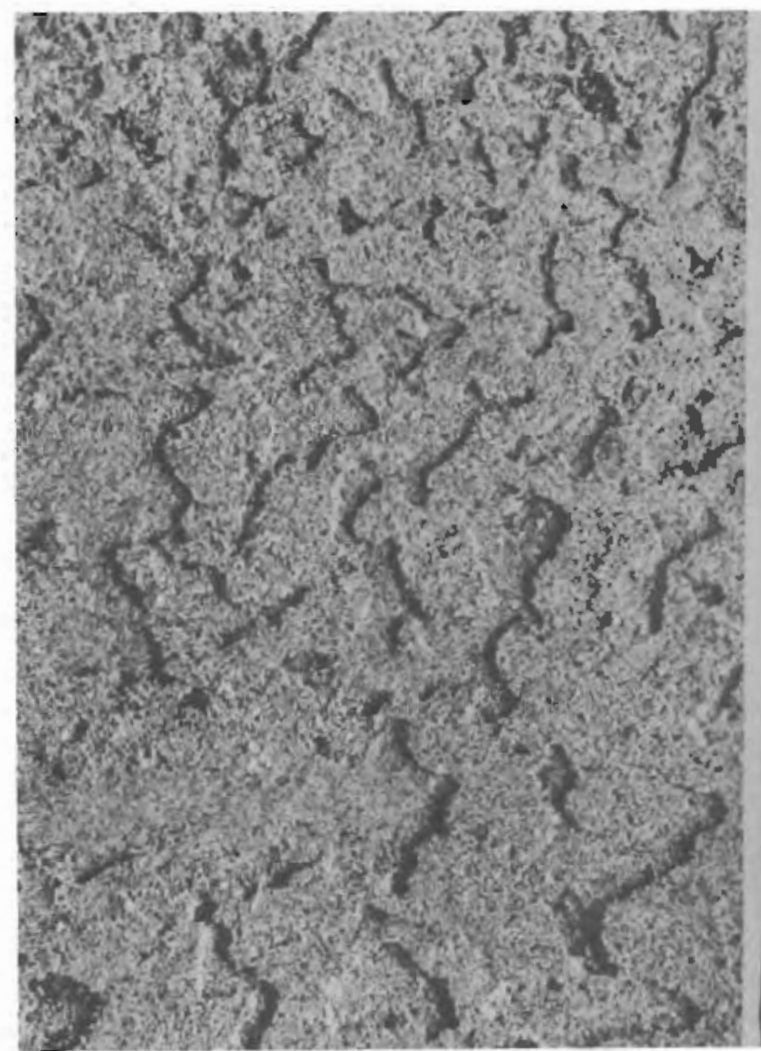

Side Next to Electrode

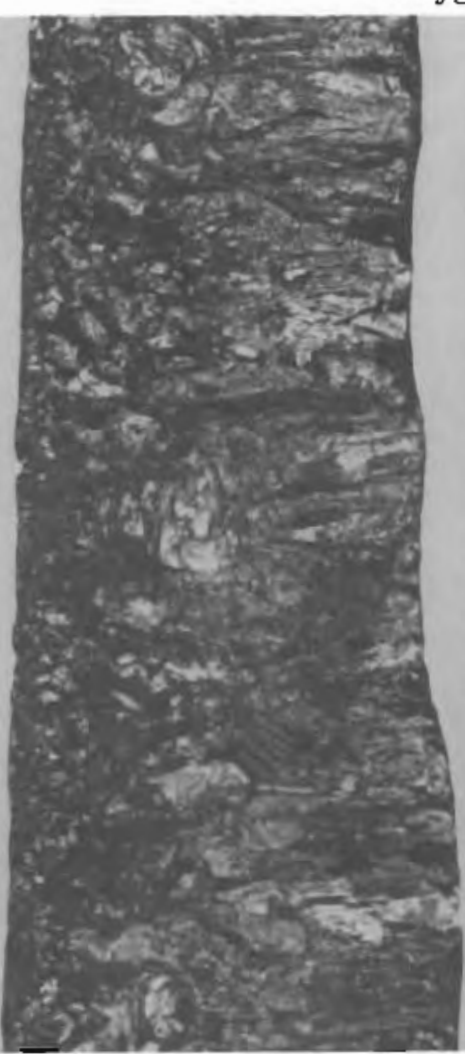

Cross Section

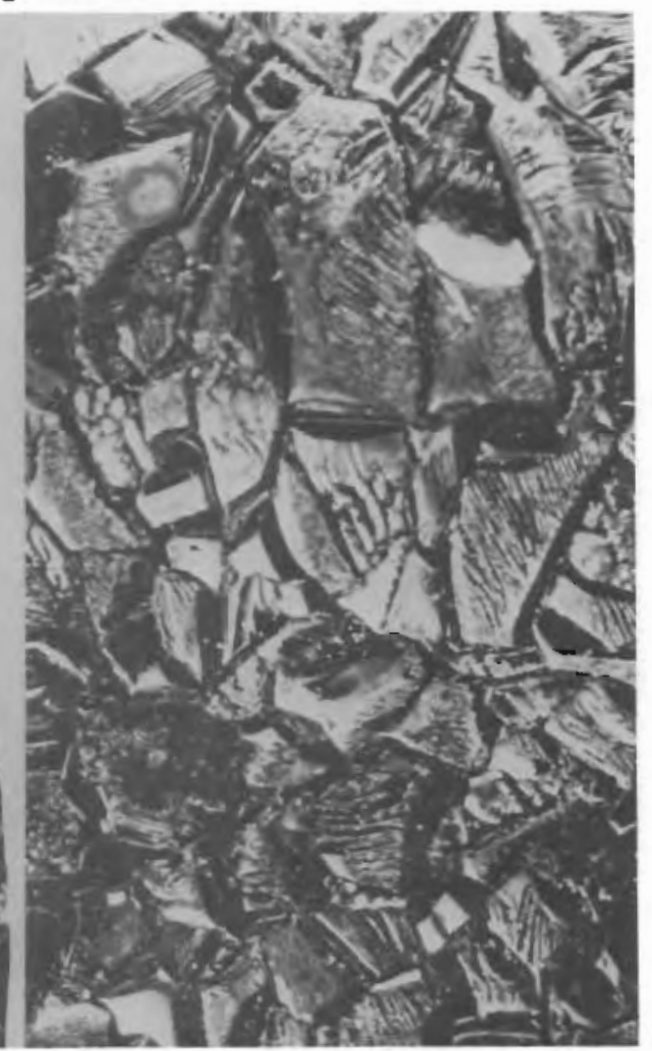

Growing Surface

FIGURE 16

$\mathrm{UO}_{2}$ Deposit from $\mathrm{NaCl}-\mathrm{KCl}$ Salt Bath

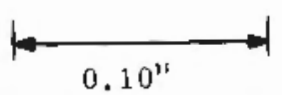

告 


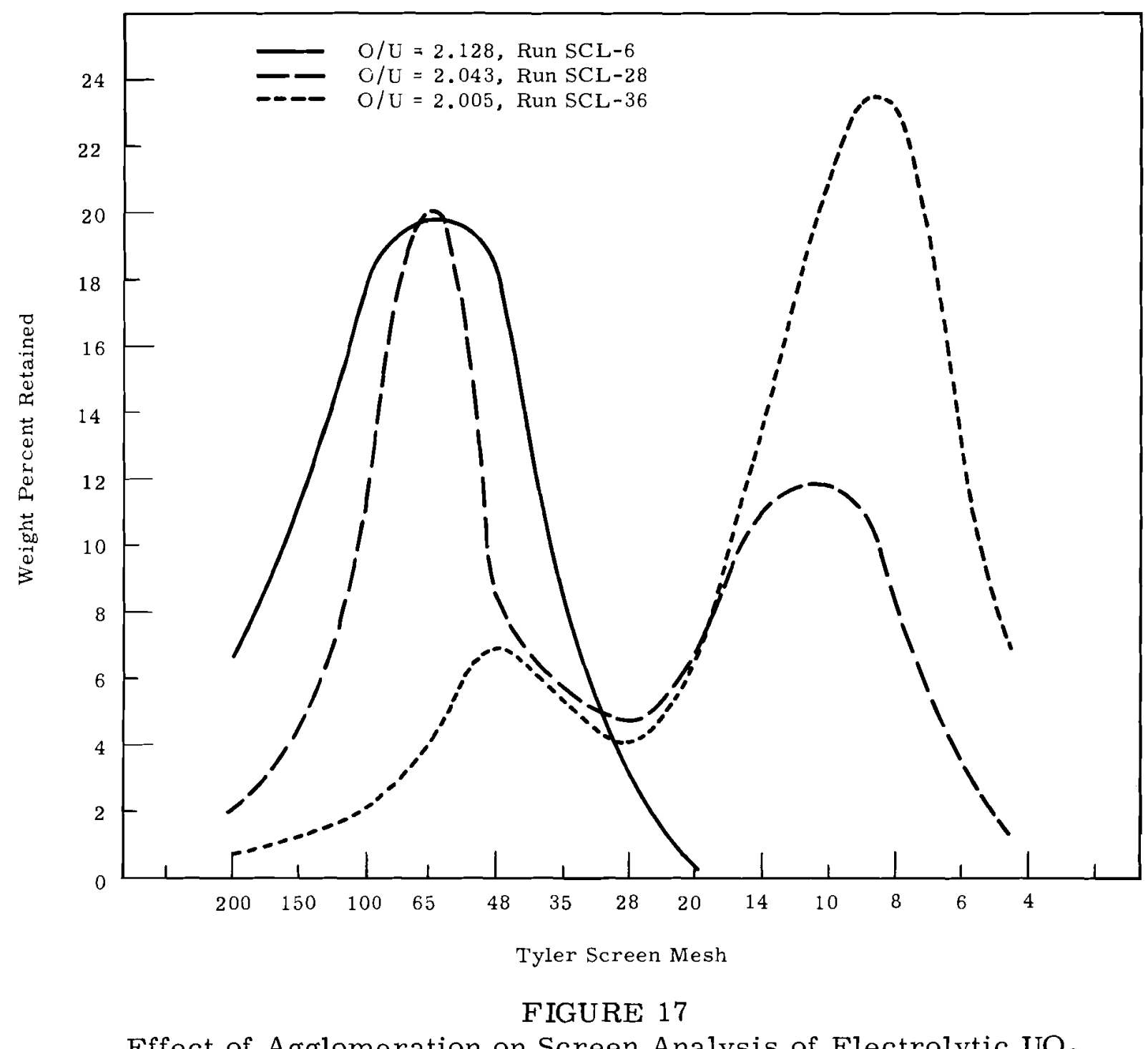




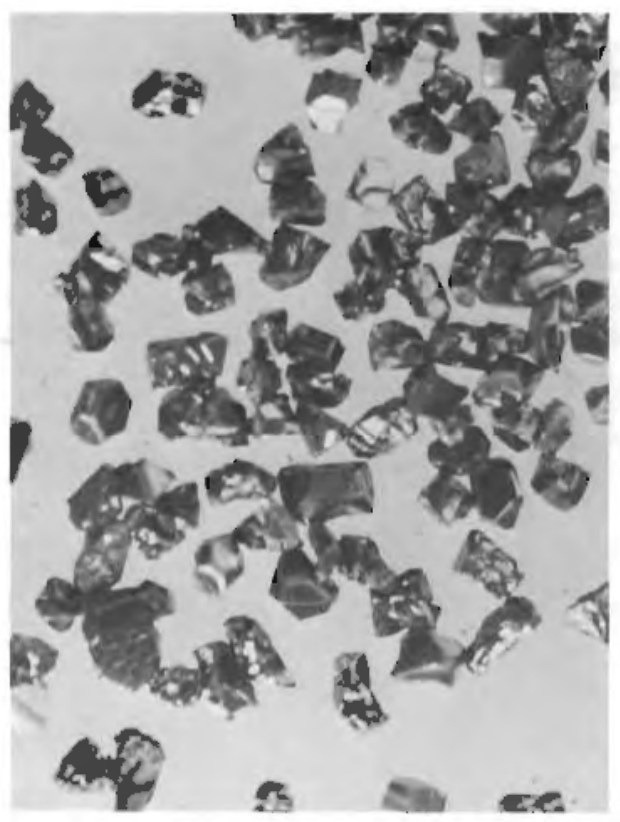

Run SCL-52 -35+45 Mesh,

$\mathrm{O} / \mathrm{U}=2.016$

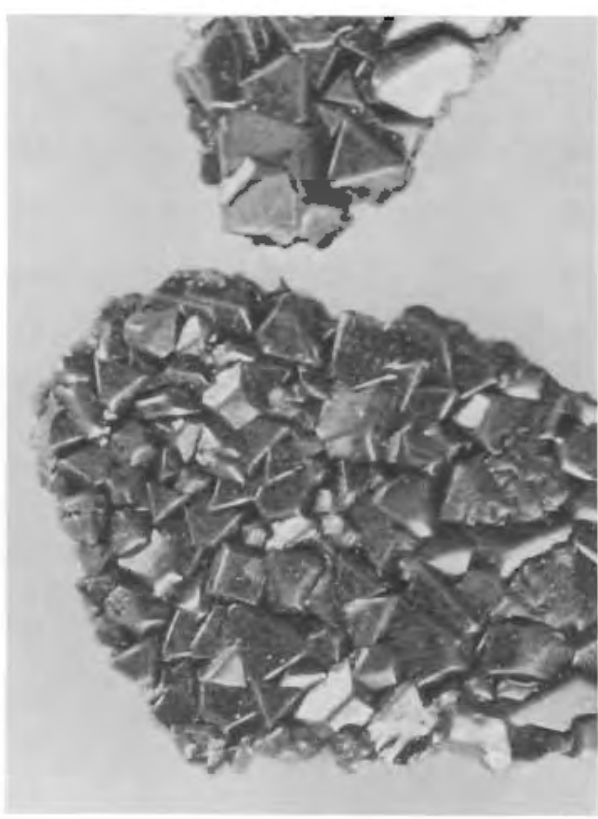

Run SCL-56 -6+10 Mesh,

$\mathrm{O} / \mathrm{U}=2.007$

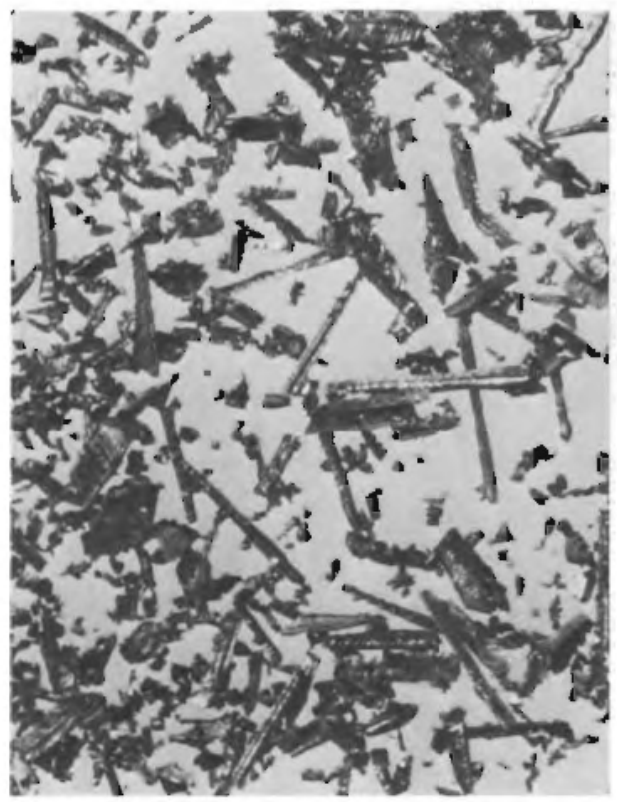

Run SCL-61, Unscreened, $\mathrm{O} / \mathrm{U}=2.038$

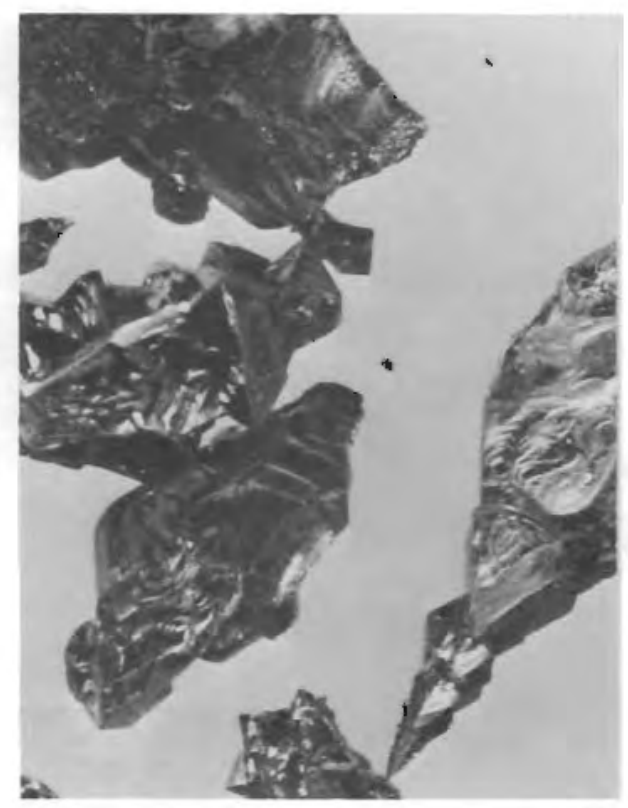

Run SCL-65, Unscreened, $\mathrm{O} / \mathrm{U}=2.062$

FIGURE 18

Crystal Characteristics of $\mathrm{UO}_{2}$ Deposited from NaCl-KCl 
grab sampling, inaccuracy of analytical techniques which had not been perfected for low concentration ranges of impurities, and planned changes in operating conditions that were tried to obtain better products. The sodium, potassium, and chlorine contents of the product varied randonly, being neither a function of the $O / U$ ratio or the crystal structure of tire deposit. The sodiun- and potassiurn-to-chloride ratios were consistently higher than if $\mathrm{NaCl}$ or KCl were occluded in the deposit, probably because of low chloride analytical results.

The carbon content of the deposit had a nedian value of $3100 \mathrm{ppm}$. This value cannot be tolerated in nuclear fuels because of carbide formation with the fuel and cladding and the possibility of gas evolution. Two major sources of carbon containination were found. Corrosion of the graphite anodes and cathodes by air above the bath surface produces a fine graphite powder which falls into the bath, permeates the entire system and is eventually incorporated in the deposit. Graphite also adheres to the surface of the deposit when it is mechanically removed from the electrode.

The graphite concentration found in the fines of a screened deposit was 5 to 10 times freater than that in larger size particles. Either the particle size of the graphite or graphite-bearing $\mathrm{UO}_{2}$ was originally small or abrasion during screening occured. However, most of the graphite is not distributed throughout the interior of the particles. Separation of the Eraphite from the $\mathrm{UO}_{2}$ by kerosene was attempted, but the $\mathrm{UO}_{2}$ collected at the kerosene-water interface and part of it was present in both phases.

The oxygen-to-uranium ratio was apparently deterained primarily by the wetness of the melt and the atmosphere. Poor atmospinere control was inherent in the apparatus, since an air sweep was passing over the bath surface to cool the Iransite iid. The gas pretreatment of the melt is a strong factor in determining the $\mathrm{O} / \mathrm{U}$ ratio of the product. Individual runs with each reed material showed that $0 / U$ ratios below 2.01 can be obtained with $\mathrm{UO}_{2}, \mathrm{UO}_{2} \mathrm{Cl}_{2} \cdot \mathrm{H}_{2} \mathrm{O}$, or $\mathrm{U}_{3} \mathrm{O}_{3}$ feeds with a controlled-atmosphere syster and suitable sparge times. 
BNWL -354

\section{EQUIPMENT FOR PIIOT PLANT OPERATIONS}

An induction-heated, fused silica electrolytic $\mathrm{UO}_{2}$ pilot plant was constructed after completion of most of the $\mathrm{NaCl}-\mathrm{KCl}$ studies. The $\mathrm{NaCl}-\mathrm{KCl}$ operations reported in Table VII, the $\mathrm{PbCl}_{2}-\mathrm{KCl}$ pilot plant operations, and the 80-liter $\mathrm{LiCl}-\mathrm{KCl}$ operations were conducted in the new apparatus.

\section{Electrolytic Cell}

The design of the electrolytic cell crucible and secondary container used in pilot plant operations is illustrated in Figure 19. The necessity for using fused silica because of corrosion to metals dictated a simple pot for the melt crucible. The fragile nature of the pot in turn, imposed limitations on the design of the secondary containers and lids for containing the chlorine and hydrogen chloride. Since the secondary container was also to be used as an induction-heating susceptor, additional geometric considerations were involved.

Two sizes of electrolytic cell crucibles were used in the pilot scale tests. These were 9-in.-diam, 30-in.-high and 18-in.-diam, 30-in.-high fused silica pipes with one end closed by fusion. The fused ends were hemispherical, providing a good geometry for dissolution operations and a mechanically strong base.

The secondary containers for the crucibles were metal cylinders with bottoms welded in place designed to provide a stable footing and a simple geometry for use as a susceptor with an induction heating coil. Rims were welded to the top to mate with the drybox or double chamber lids.

In the early studies with the smaller crucibles, a Transite lid with side arm connected to an off-gas vacuum system was used. A slotted top provided access for dissolution and electrolysis equipment. This design allowed some air to sweep over the top of the melt.

The lid design for the large crucibles was originally the same as for the 9-in. pots but difficulty was encountered in obtaining an air-free atmosphere over the melt because of poor sealing at the mating surfaces. A double lid was developed to provide an air-free lower chamber above the melt and an upper chamber with an exhaust for chlorine to an off-gas scrubber. 

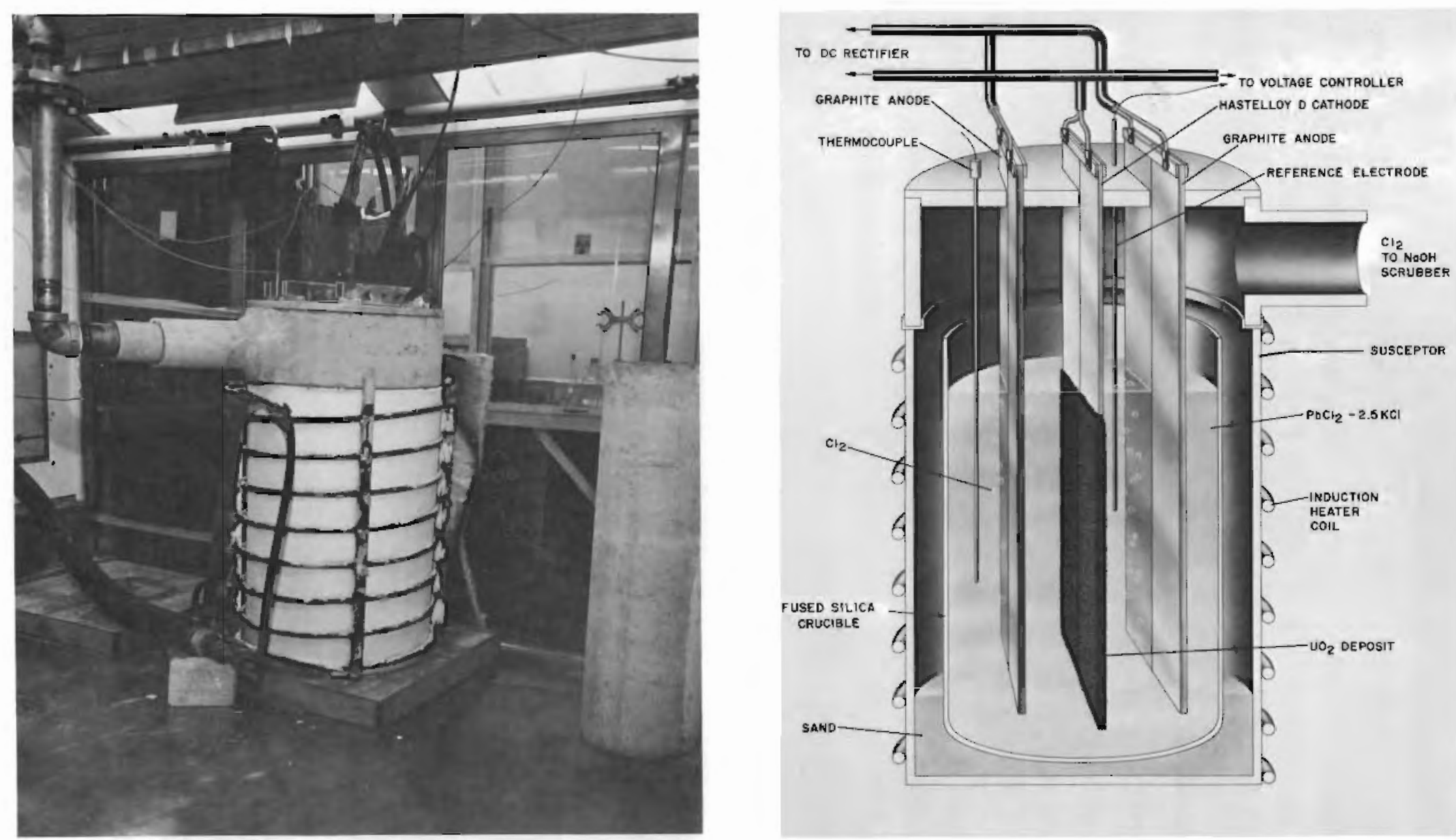

$\stackrel{5}{0}$

FIGURE 19

Eighty Liter Pilot Plant Salt Bath for $\mathrm{PbCl}_{2}-\mathrm{KCl}$ System 
The lid mated with the susceptor through a quartz wool seal, A Hastelloy $C(\mathbb{B}$ plate separated the lower melt chamber from the upper off-gas removal chamber. Holes in the plate provided access for process equipment such as electrodes, spargers, and thermowells. Electrodes were gasketed with Lavite (P) plates to minimize air access to the melt atmosphere.

A caustic tower removed chlorine from the off-gases. An 8-ft.section of the 12-in。-diam column was packed with stainless steel Raschig rings. The off-gases were drawn through the tower with a $150 \mathrm{cfm}$ capacity jet, The tower, associated piping and feed tanks were made of stainless steel. However, stainless steel is not a satisfactory material for a chlorine scrubber and frequent replacement of pumps and lines was necessary。

Two major pieces of electrical equipment were used with the electrolysis cell. An automatic control rectifier with a 500-amp 12-volt output was used in the electrolysis studies. It was modified to incorporate an optional reference electrode control system. A 10-kc 30-kW motor generator set was used for induction heating of the electrolysis cell. The salt temperature was controlled by on-off control with automatic switching to four power levels.

Auxiliary equipment consisted of gas lift recirculators, sparge tubes, thermocouple shields, vacuum transfer lines, and a waste salt receiving container with an especially designed lid for vacuum transfer. The gas lift recirculators were quartz tubes of varying sizes and shapes to which plastic gas supply tubes were attachedo Quartz tubes were used for vacuum transfer lines with sparge tubes and thermocouple sheaths. The hot salt waste receiver was a stainless steel cylindrical tank with a lid equipped with a ball joint socket and a vacuum line. A silicone rubber gasket provided a vacuum-tight seal between the receiver and the lid, Stainless steel was used for the receiver tank because the short exposure to the molten salt before freezing produced little corrosion.

(B) Union Carbide Company
(R) D. M. Steward $\mathrm{Mfg}$. CO。 


\section{Instrumentation}

The instrument systems used in the pilot plant include a reference electrode for electrolysis voltage control, a potentiometric microelectrode for determining melt dryness, and automatic shutoff and telephone recording warning device in the event of crucible failure or heater shutdown. An ampere-hour integrator was used to determine the amount of $\mathrm{UO}_{2}$ that should theoretically have been deposited during electrolysis according to Faraday's law. The electrolysis efficiency was then calculated using this figure compared to the weight of $\mathrm{UO}_{2}$ deposited Conventional recorders for temperature, voltage and current were also used, A description of other experimental apparatus such as liquid level indicators, continuous density recorders, and $U(I V)$ photometers is given el sewhere, $(22,23)$

\section{Reference Electrode Control System}

The reference electrode voltage control system maintained the cathodeto-melt potential below the decomposition potential of the carrier salts. The components of the system are a reference electrode, a pH meter used as a millivoltmeter, a recorder-controiler and a 500-amp 12-volt rectifier with an automatic voltage control system operating from the controller signal. The reference electrode is a $\mathrm{Ag} / \mathrm{AgCl}$ half cell consisting of a quartz tube with a Pyrex membrane bottom. Its components are a 1 molal solution of $\mathrm{AgCl}$ in a $2.5 \mathrm{KCl}-\mathrm{PbCl}_{2}$ melt surrounding a silver wire. A high impedance millivoltmeter is required to measure the reference electrode potential since only a few microamperes pass through the circuit because of the high resistance of the Pyrex membrane. The recorder-controller amplified the weak signal from the $\mathrm{pH}$ meter into a usable error signal for the automatic voltage control system on the rectifier.

The initial voltage of the reference electrode system is the sum of two half cell reactions

The reference electrode

$$
2 \mathrm{AG}^{+}+2 \mathrm{e}^{-}+2 \mathrm{Ag}
$$

and at the cathode

$$
\mathrm{UO}_{2} \rightarrow \mathrm{UO}_{2}^{++}+2 e^{-}
$$


The initial voltage is the sum of the two half cell reactions (approximately $400 \mathrm{mV}$ ) and decreases as the initial $\mathrm{UO}_{2} \mathrm{Cl}_{2}$ concentration of the melt is lowered。

In practice, an electrolysis was conducted for a few minutes to cover the surface of the cathode with $\mathrm{UO}_{2}$. The electrolysis was then stopped and the potential difference between the cathode and the reference electrode (about $-400 \mathrm{mV}$ ) was read on the recording millivoltmeter. Then the electrolysis was resumed, and the potential as read on the meter was held at a predetermined usually positive value during electrolysis. The operating point was set below the decomposition voltage of the carrier salts (see Figure 12, page 38)。 Dryness Test Apparatus

The potentiometric microelectrode system for determining the dryness of the melt operates on the same principle as the reference electrode control system. There are three electrodes used; a small anode, a reference electrode and a microelectrode for a cathode. The output voltage to the anode and cathode is controlled by naintaining a constant voltage across the reference electrode and the cathode, A plot of current versus time is recorded over about a 15-minute interval (see Figure 21, page 57)。 Since very little current is passed (less than 5 amperes) the concentration of the melt remains unchanged. Any change depends only on a change in the plating area of the microcathode. In wet melts dendritic deposits are made which tend to increase the area and hence give a positive slope to the current versus time curve. In dry nelts the deposits are dense, flat and closely packed with very little change in surface area. A comparatively flat curve is obtained in this case. The curve may even have a negative slope for dry melts since there is an initial expansion of electrode deposition surface before the crystal formation becomes stable。A constant temperature must be maintained during the drying test to get meaningful results.

\section{Crucible Breakage Alarm}

An alarm system was installed on the heating system for the large crucible to provide early warning of crucible breakage at heater shutdown. The 
device was activated by the shutdown of the motor generator for the induction heating coil. The motor generator was shut down by low pressure on the cooling water lines to the coil or the motor generator, by electrical failure, or by an automatic shut-off device activated by a leak in the molten salt crucible.

The shutoff after crucible breakage was accomplished by the molten salt short circuiting two wires placed in the annulus between the crucible and the secondary container. These platinum wires were in quartz tubes and they terminated near the bottom of the secondary container where molten salt would collect upon crucible breakage. Shutdowns due to water or electrical failures could be remedied before the melt in the crucible froze, minimizing crucible breakage and the resulting expensive and time consuming cleanup operations, If the crucible broke, immediate shutoff and notification prevented equipment damage and permitted prompt action to simplify the salt removal and cleanup work.

IEAD CHLORIDE-POTASSIUM CHLORIDE PILOT PLANT OPERATIONS

After it became clear from laboratory data ${ }^{(24)}$ that lower operating temperatures could be achieved in a solvent of composition 2.5 moles $\mathrm{KCl}$ per mole $\mathrm{PbCl}_{2}$, pilot plant operations were started in this system. The primary incentives for the change were lower corrosion rates of graphite and metallic materials of construction and the possibility of producing larger deposits because of a lower rate of $U(I V)$ buildup in the melt. The pilot plant operations in the 20 liter crucible are summarized in Table I\%, page 55, and for the 80 liter crucible in Table $x$, page 63.

\section{Dissolution}

Dissolution of the $\mathrm{UO}_{3}$ and $\mathrm{U}_{3} \mathrm{O}_{8}$ feed materials in the $2.5 \mathrm{KCl}-\mathrm{PbCl}_{2}$ system was conducted with chlorine gas sparged through $6 \mathrm{~mm}$ quartz tubing. The temperature during dissolution was nominally $700^{\circ} \mathrm{C}$. Dissolution occurred readily when sufficient mixing of chlorine gas and the feed material was attained。 Good mixing was obtained in small crucibles where the feed was easily fluidized but became poorer as vessel size increased. 
Since the normal operating period was only $3 \mathrm{hr} /$ day except for the last three runs (NPI 2l-23), dissolutions were discontinuous and dissolution rate data were collected in only two cases.

The dissolution data for runs NPL-1l and NPI-12 in 20 liter crucibles is shown in Figure 20. The curves show a slow buildup of uranium in solution with the rate gradually decreasing as the feed material was dissolved。 The amount of chlorine gas used is plotted on the same graphs to indicate the excess required to produce $\mathrm{UO}_{2} \mathrm{Cl}_{2}$. In NPL-12, over $100 \%$ use of chlorine was observed during the first few hours. This was attributed to the solubility of $\mathrm{U}_{3} \mathrm{O}_{8}$ in the melt and to suspended oxide. $\mathrm{U}_{3} \mathrm{O}_{8}$ is soluble in the $2.5 \mathrm{KCl}-\mathrm{PbCl}_{2}$ molten salt up to $5 \mathrm{wt} \%$, increasing with $\mathrm{UO}_{2} \mathrm{Cl}_{2}$ concentration. The tests results indicated that dissolution was not a great problem in the smaller crucibles.

Some difficulty was experienced during dissolution of feed in the 80 liter crucibles. The chlorine sparge was insufficient to fluidize the feed, particularly after a dissolution has been discontinued overnight. However, dissolution usually went rapidly with pure feed。 In the last few runs, feed with impurities including iron, sand, and metal turnings did not completely dissolve, and left inert impurities and $\mathrm{U}_{3} \mathrm{O}_{8}$ sludge in the bottom of the crucibles. This experience pointed out the need for a melt stirrer or circulator to promote fluidization of the feed for increased dissolution rates. A submerged gas-lift recirculator was developed after the conclusion of the studies in the $2.5 \mathrm{KCl}-\mathrm{PbCl}_{2}$ system and was used in the LiCl-KCl system。 Drying

Two methods of drying the molten salt solution after completion of the dissolution step were tried in the last three runs of the series. One method involved further sparging with chlorine or hydrogen chloride gas。 The other consisted of a pre-electrolysis step in which $\mathrm{UO}_{2}$ was plated out on the anodes prior to the final electrolysis step.

Drying of molten salts with chlorine gas had been quite successful in the laboratory. The use of hydrogen chloride gas was even more effective than chlorine during uranium dioxide crystal growth studies by Chemical 


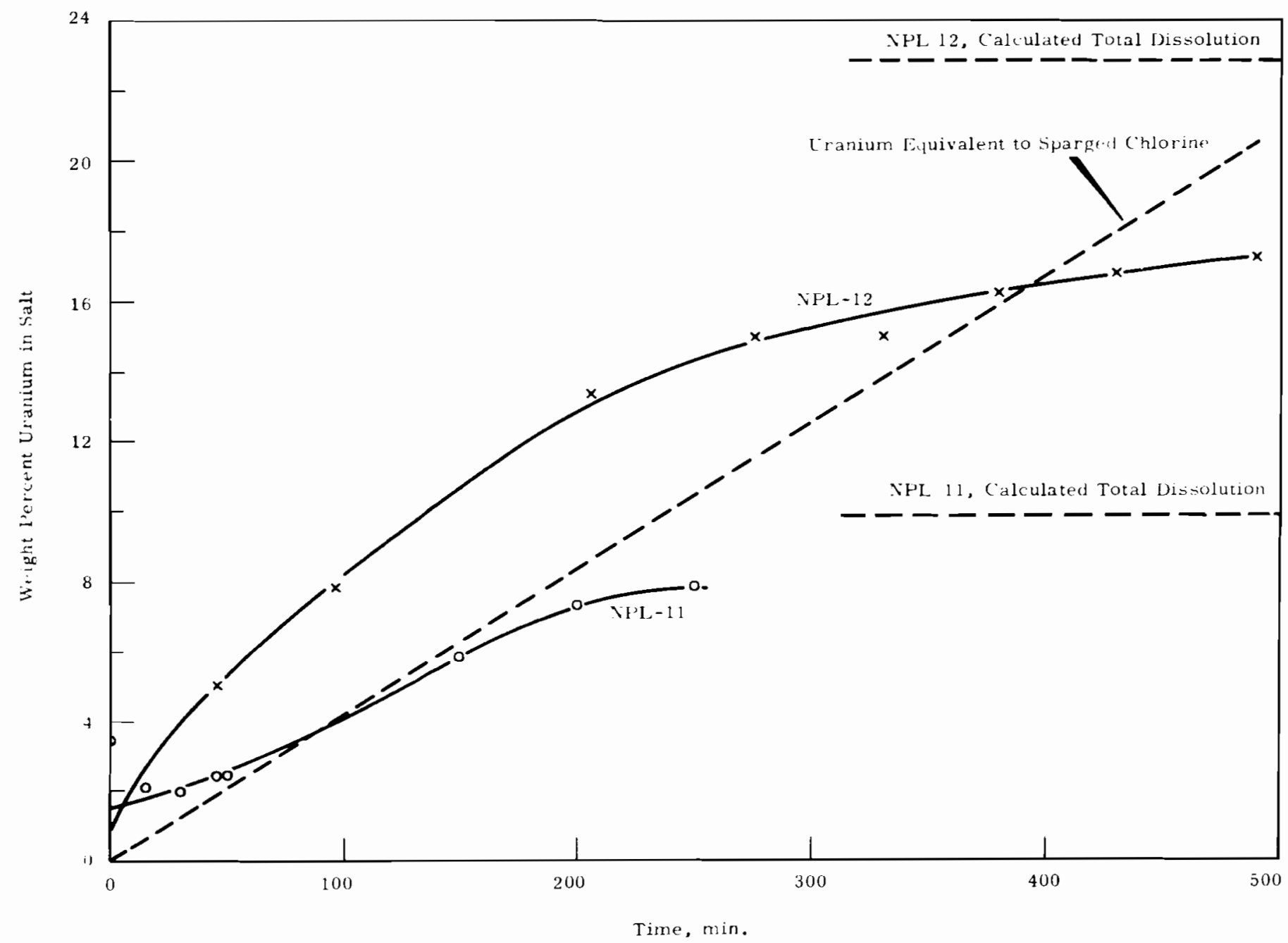

FIGURE 20

Dissolution of $\mathrm{U}_{3} \mathrm{O}_{8}$ in $\mathrm{PbCl}_{2}-2.5 \mathrm{KCl}$ 


\section{TABLE IX}

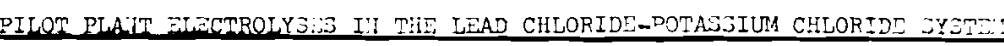

Twenty Liter jelt Bath

Salt System: 2.5 moles $\mathrm{KCl} /$ mole $\mathrm{PbCl}$

Melt Weight: 100-130 lb total

Dissolution Temperature: $675-710^{\circ} \mathrm{C}$

Feed laterial: UU 3 Powder, except as noted

\begin{tabular}{|c|c|c|c|c|c|c|c|c|c|c|c|c|c|c|c|c|}
\hline \multirow[b]{3}{*}{ Run No. } & \multicolumn{5}{|c|}{ DISSOLUTIOII } & \multicolumn{11}{|c|}{ ELECTROLYSIS } \\
\hline & \multirow{2}{*}{$\begin{array}{c}\text { Feed } \\
\text { wt, } 1 \mathrm{~b} \\
\end{array}$} & \multirow{2}{*}{\multicolumn{2}{|c|}{$\begin{array}{l}\text { Moles } \mathrm{Cl}_{2} \text { Used per } \\
\text { Mole U Dissolved } \\
\end{array}$}} & \multirow{2}{*}{$\begin{array}{l}\text { Avg Flow } \\
\ell / \min \\
\end{array}$} & \multirow{2}{*}{$\begin{array}{l}\text { Tine, } \\
\text { hr } \\
\end{array}$} & \multirow{2}{*}{$\begin{array}{l}\text { Average Cell } \\
\text { Volts } \\
\end{array}$} & \multicolumn{2}{|c|}{$\begin{array}{l}\frac{\text { REF, POTEITIAL }}{\text { Volts }} \\
\end{array}$} & \multirow{2}{*}{$\begin{array}{l}\text { Tenp. } \\
{ }^{\circ} \mathrm{C} \\
\end{array}$} & \multirow{2}{*}{$\begin{array}{l}\text { CONCENTI } \\
\text { Initial } \\
\text { wt }{ }_{p}^{\prime} \mathrm{U} \\
\end{array}$} & \multirow{2}{*}{$\begin{array}{l}\text { RATION } \\
\text { Final } \\
\text { wt\% U } \\
\end{array}$} & \multirow{2}{*}{\multicolumn{2}{|c|}{ 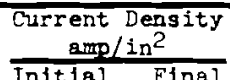 }} & \multirow{2}{*}{\multicolumn{2}{|c|}{$\begin{array}{l}\text { Time, } \\
\mathrm{hr} \\
\end{array}$}} & \multirow{2}{*}{$\begin{array}{l}\text { Current } \\
\text { Eff.e }\end{array}$} \\
\hline & & & & & & & min. & $\underline{\max .}$ & & & & & & & & \\
\hline :PL-6 & 28 & & 2.2 & 2.5 & 13.6 & 1.2 & $-\infty$ & - & $550-580$ & 16.6 & 3.2 & 2.92 & 1. & \multicolumn{2}{|c|}{27.6} & 86.9 \\
\hline NPL-7* & 40 & & 1.7 & 2.4 & 12.6 & 1.3 & - & -- & $525-565$ & 22.5 & 12.2 & 1.29 & 0. & \multicolumn{2}{|c|}{46.5} & 81.4 \\
\hline IPL-8* & 10 & & 6.3 & $\approx 2$. & 18.6 & 1.1 & - & $-\infty$ & $550-600$ & -- & 11.1 & 0.97 & 0. & \multicolumn{2}{|c|}{21.3} & -- \\
\hline JPL-9* & 20 & & 2.3 & 2. & 14 & 2.0 & 0.52 & 0.58 & $560-660$ & 16.9 & 2.0 & $2.25 *$ & & \multicolumn{2}{|c|}{23.0} & 46. \\
\hline NPI-10 & 5 & & 10.4 & $2-3$ & $12.4+$ & 1.6 & 0.51 & 0.52 & $580-600$ & 8.2 & 0.12 & $0.61 * *$ & 0. & $2 \quad 17$ & .4 & --- \\
\hline & & & & SLECTRODES & & & & & & & & RODUCT & & & & \\
\hline Run Jo. & Materia & $\frac{\text { Cathc }}{\text { gl }}$ & $\frac{\text { ode }}{\text { Area, in. }}$ & Interi & Anode & Area, in ? & $\begin{array}{l}\text { Deposit } \\
\text { wt, lo }\end{array}$ & o/U Ret & $\frac{\text { Densi }}{9 \mu}$ & $\frac{\text { ity, } 8 / \mathrm{cm}^{3}}{0.06 \mu}$ & $\frac{\mathrm{Im}}{\mathrm{Pb}}$ & mpuritie & es,pe & & & $s$ \\
\hline 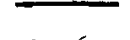 & & & & & & & & & & & & & & & & \\
\hline NPL-6 & Carbon & & 54.75 & Carbon (2) & & 110 & 20.2 & 2.015 & -- & -- & - & -- & -- & 306 & See & Figures 22 and 24 . \\
\hline$\because P L-7$ & $\begin{array}{l}\text { Carbon } \\
\text { (round) }\end{array}$ & & 72 . & $\begin{array}{l}\text { 6-in. ID Ann } \\
\text { Carbon (I) }\end{array}$ & ular & 635 & 23.5 & 2.030 & - & -- & 1111 & $<50$ & 50 & -- & & $\begin{array}{l}\text { g dendritic crystals } \\
\text { outside. }\end{array}$ \\
\hline :IPL-8 & $\begin{array}{l}\text { Carbon } \\
\text { (round) }\end{array}$ & & 72 . & $\begin{array}{l}6 \text {-in. ID Ann } \\
\text { Carbon with } \\
\text { holes }\end{array}$ & $\begin{array}{l}\text { ular } \\
12 \text { l-in. }\end{array}$ & - & 73. & 2.018 & -- & -- & -- & $<50$ & 260 & --- & -- & -- \\
\hline IPL-9 & $\begin{array}{l}\text { Carbon } \\
\text { (round) }\end{array}$ & & 72. & $\begin{array}{l}\text { Annular Carb } \\
\text { b-in. dian }\end{array}$ & & 635 & 13.5 & 2.013 & 10.93 & 11.00 & 564 & 170 & 200 & 1250 & Sii & ghtly dendritic. \\
\hline$\therefore L-10$ & Ilastello & oy D & 197. & Carbon (2) & & 110 & -- & -- & -- & $-\infty$ & - & - & - & -- & $\begin{array}{l}\text { Fia } \\
\text { Som }\end{array}$ & $\begin{array}{l}\text { t. plate-like, small. } \\
\text { ae included lead. }\end{array}$ \\
\hline 12 & Hasteilo & 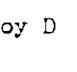 & 197. & Carbon (2) & & 110 & $1:+3$ & $<2.01$ & 10.74 & 10.88 & 81000 & 100 & $\ldots$ & 1500 & $\begin{array}{l}\text { Fla } \\
12\end{array}$ & $\begin{array}{l}\text { t. plate-like, small, } \\
\text { ppm Fe, } 100 \text { ppm } 7 i .\end{array}$ \\
\hline
\end{tabular}

* Bun began vith salt fron previous run.

* Culorine sjarge during electrolysis.

*** U U $\mathrm{U}_{3}$ porder.

thIso dried dith IICl at 3 liters/min for $40 \mathrm{~min}$ 
Research personnel。(24) Similar results were obtained during the last few pilot plant studies in the $2.5 \mathrm{KCl}-\mathrm{PbCl}_{2}$ series. In the earlier runs the salt was not dried after dissolution since the magnitude of the effect of wet melts on crystal characteristics had not yet been determined.

The pre-electrolysis drying step was carried out by inserting three graphite electrodes in the melt using the center electrode as an anode and the two outside electrodes as cathodes. A short electrolysis resulted in a deposit of powdery $\mathrm{UO}_{2}$ on the cathodes and melt drying by the chlorine evolved at the anode. The center electrode or anode was then replaced by a product cathode and the electrical leads were reversed so that the uranium-bearing electrodes were the anodes during the product electrolysis. The poor grade $\mathrm{UO}_{2}$ on the anodes was subsequently dissolved and dried with chlorine gas from the electrolysis reaction.

The effects of drying with a chlorine sparge, hydrogen chloride sparge and pre-electrolysis are illustrated in Figure 2l。 The drying curves for run NPL-2l, in which all three methods were tried and in which a $\mathrm{UO}_{2}$ product with an 0/U ratio of 2.004 was produced, are shown. The drying curves are current versus time for a glass-sheathed platinum microelectrode operated at constant voltage. After an initial decrease in current while the cathode is being polarized, the slope of the curves indicate the approach to dryness. A positive slope indicates a wet melt while a flat or slightly negative slope indicates a dry melt. The wetter the melt the greater the magnitude of the positive slope indicated on the drying curve. (See page 51 for further description of dryness tests.)

The curves in Figure 21 show the gradual change from a wet to a dry melt. From the slopes of the curves it is apparent that a chlorine gas sparge at $700^{\circ} \mathrm{C}$ was drying the melt。 Further drying was obtained with hydrogen chloride gas at $600^{\circ} \mathrm{C}$. Pre-electrolysis at $600^{\circ} \mathrm{C}$ continued the drying process as indicated by the nearly constant current versus time Although the difference is not specifically shown here, drying at the electrolysis temperature is believed to be more effective than at the higher dissolution temperature. 


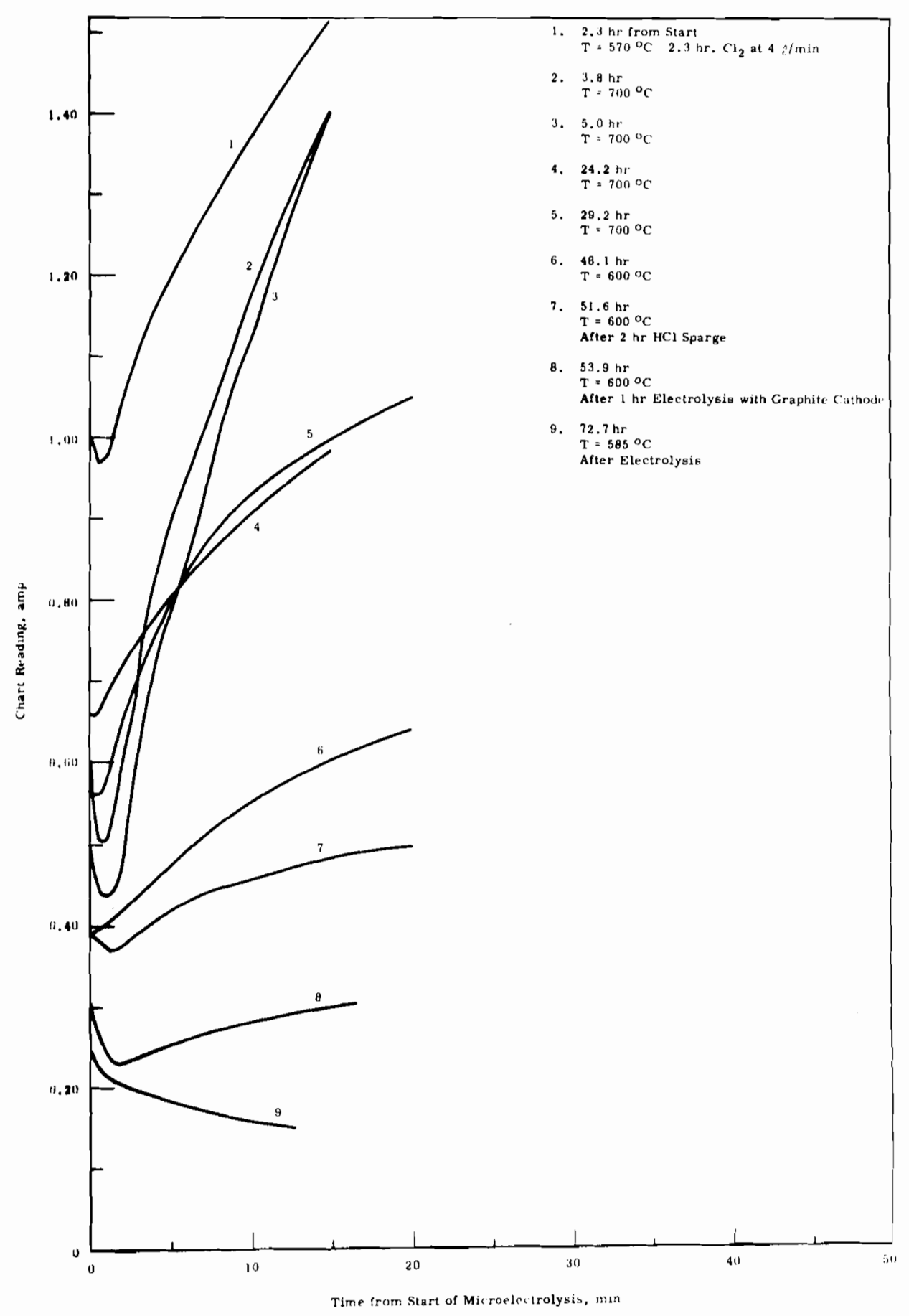

FIGURE 21

Wetness Tests in $\mathrm{PbCl}_{2}-2.5 \mathrm{KCl}$ With 30 wt\% Uranium 
The magnitude of the current on the drying curve is highly temperature dependent so that the current at $700^{\circ} \mathrm{C}$ is higher than at $600{ }^{\circ} \mathrm{C}$. The current is also affected by the microelectrode area, which varies because the apparatus is reassembled for each test. This accounts for the change in initial currents for drying curves run at the same temperature. The slope of the drying curve is the only useful factor in determining the melt dryness。

\section{Electrolysis}

The electrolytic deposition of $\mathrm{UO}_{2}$ from a molten salt melt involved a number of variables including electrolysis voltage, current density, temperature, impurities, and melt "wetness" (the presence of interfering oxides and hydroxides chemically held in the melt)。 These variables were studied on the laboratory scale by Chemical Research personnel and provided direction to the pilot plant studies which primarily involved scale up of the process and confirmation of laboratory data. Although there was good general agreement between the laboratory and pilot plant data, important effects were encountered in the latter which had not previously been extensively studied,

In the $\mathrm{PbCl}_{2}$ system the electrodeposition of reactor grade $\mathrm{UO}_{2}$ is highly dependent upon the electrolysis voltage. The electrolysis must be operated at a potential sufficiently below the decomposition potential of the carrier salts to prevent their deposition as an impurity in the $\mathrm{UO}_{2}$ 。 Curves of reference potential versus current for the deposition of $\mathrm{UO}_{2}$ and lead from $\mathrm{KCl}-\mathrm{PbCl}_{2}$ melts are shown in Figure 12, page 34 。 The deposition curve for lead from $2.5 \mathrm{KCl}-\mathrm{PbCl}_{2}$ melts (in the absence of $\mathrm{UO}_{2}$ ) is not shown in that figure, but it would be at a higher voltage than those presented. The operating range for electrolysis starts at the lowest potential at which $\mathrm{UO}_{2}$ will deposit and ends just short of the potential for lead deposition. In practice the potential is set near the maximum to provide a high $\mathrm{UO}_{2}$ deposition rate。

The initial plant runs in the $2.5 \mathrm{KCl}-\mathrm{PbCl}_{2}$ system were made in a 20 liter fused silica crucible 9-in。 diam and 30-in。 high. Three types of cathodes were used in the tests. A cylindrical graphite cathode in an 
annular anode and a rectangular graphite cathode with a rectangular graphite anode on each side were tried. A Hastelloy $D$ cathode between two graphite anodes was also tested. Typical deposits on these cathodes are shown in Figure 22. The dryness of the melts could not be directly determined in the early runs because the method had not yet been developed. However, the product crystal characteristics and oxygen-to-uranium ratio of the pilot plant product were somewhat different than for laboratory runs made under completely dry conditions. A cross section of a typical deposit is shown in Figure 23. The $0 / U$ ratios did not exceed 2.04 (as compared to 2.02 specifications) in any of the 20 liter scale runs, indicating a relatively dry melt and atmosphere in spite of the use of only a single lid with air inleakage. The snall surface-to-volume ratio of the 20 liter crucible promoted chlorine blanketing from the anode reaction, accounting for the comparatively low oxygen-to-uranium ratios obtained.

In the last three runs, NPL-9, 10 and 12 on the 20 liter scale, a reference electrode control system described on pages 50 and 51 controlled the electrolysis voltage. In one run (NPL-10) metallic lead was plated out during the electrolysis while operating at a high reference voltage. The next run (NPL-12) was operated at a voltage within the desired range and resulted in a product with good crystal structure without visible lead in the deposit. Hence, the usefulness of the reference electrode control system and the direct use of laboratory electrolysis potential data for pilot scale operations was establis'hed.

The pilot plant crucible size was increased to 80 liters which is full scale operation for reprocessing a single fuel element from the Plutonium Recycle Test Reactor. The results of these runs are presented in Table $X$. In the first run (NPL-13), 6013 of $\mathrm{UO}_{2}$ were deposited and in the second (NPL-14), $116 \mathrm{lb}$. The product in each case was the mace type $\mathrm{UO}_{2}$ (shown in Figure 24) with oxygen-to-uranium ratios of 2.04 and 2.09 , respectively. The melt atmosphere was a mixture of air and chlorine since the chlorine from the anode reaction was diluted by an air sweep to the off-gas system. The crystal shape and oxygen-to-uranium ratio indicated the melt was not completely dry. Uranium (IV) buildup in the melt was not detectable at the electrolysis temperature of $590 \pm 20^{\circ} \mathrm{C}$. 


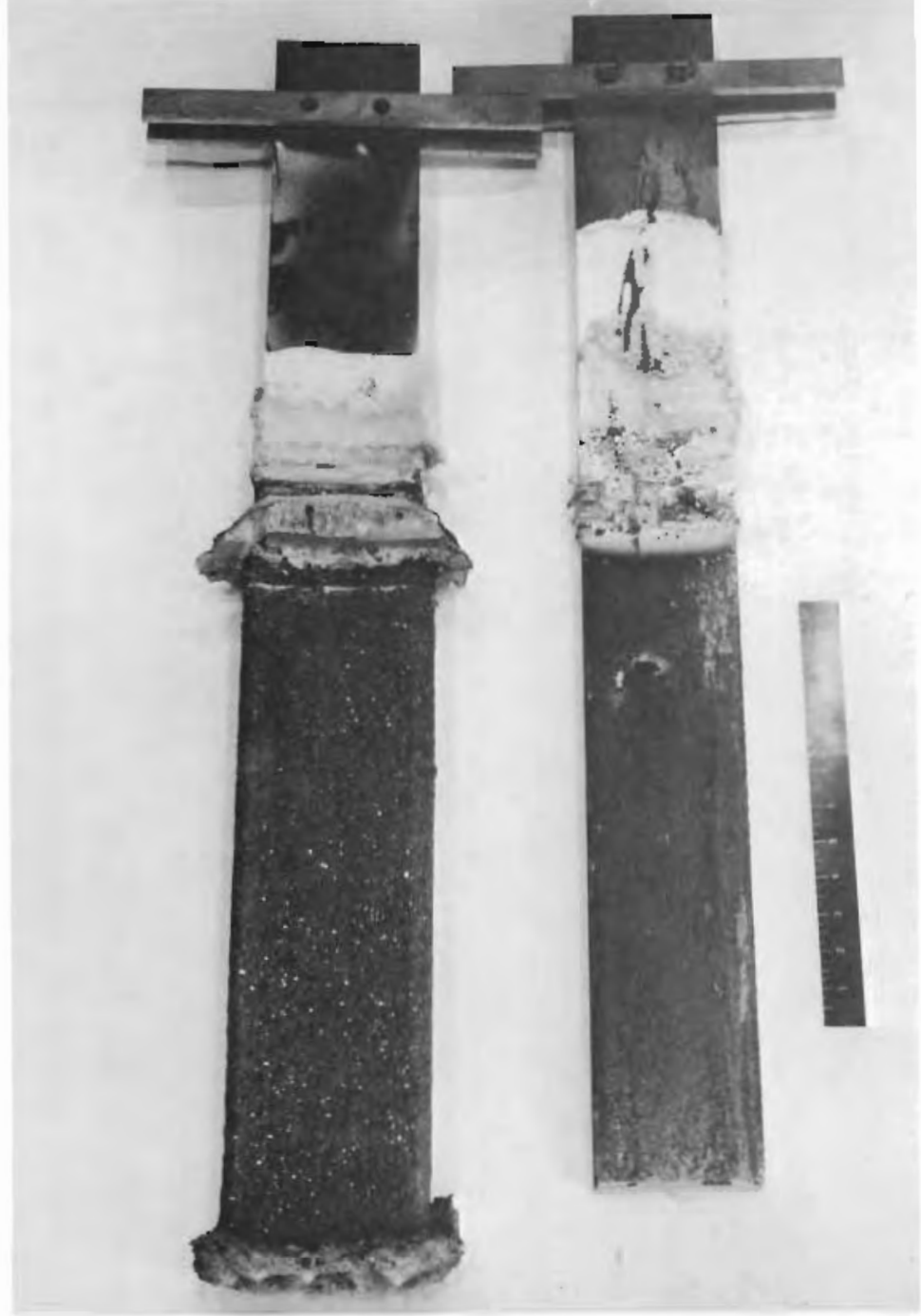

Run NPL-6, $20 \mathrm{lb}$. Deposit on Graphite Cathode, $\mathrm{O} / \mathrm{U}=2.015$

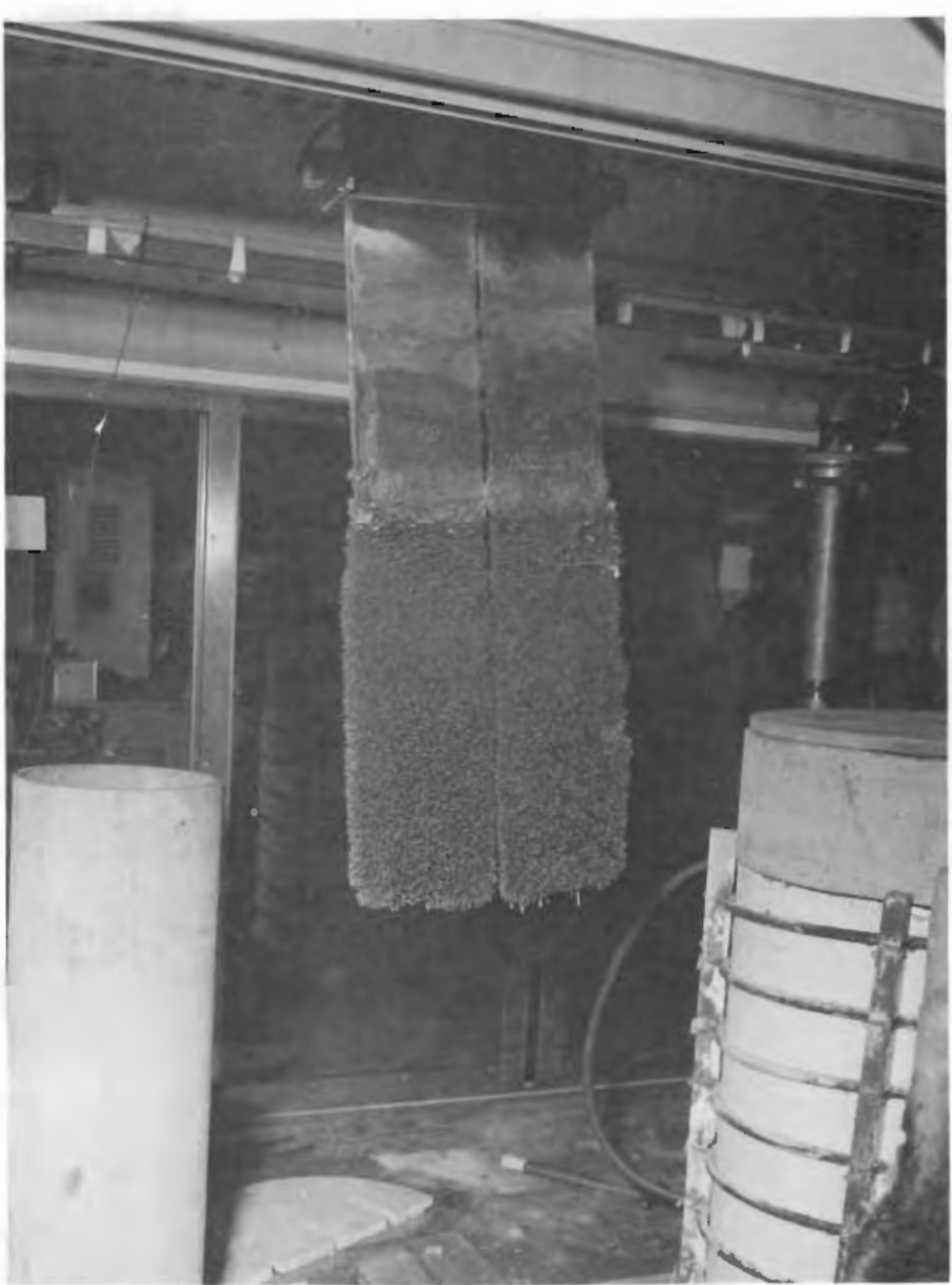

焉
Run NPL 13, 60.3 1b. Deposit on Hastelloy D Cathode, $\mathrm{O} / \mathrm{U}=2.04$

FIGURE 22 


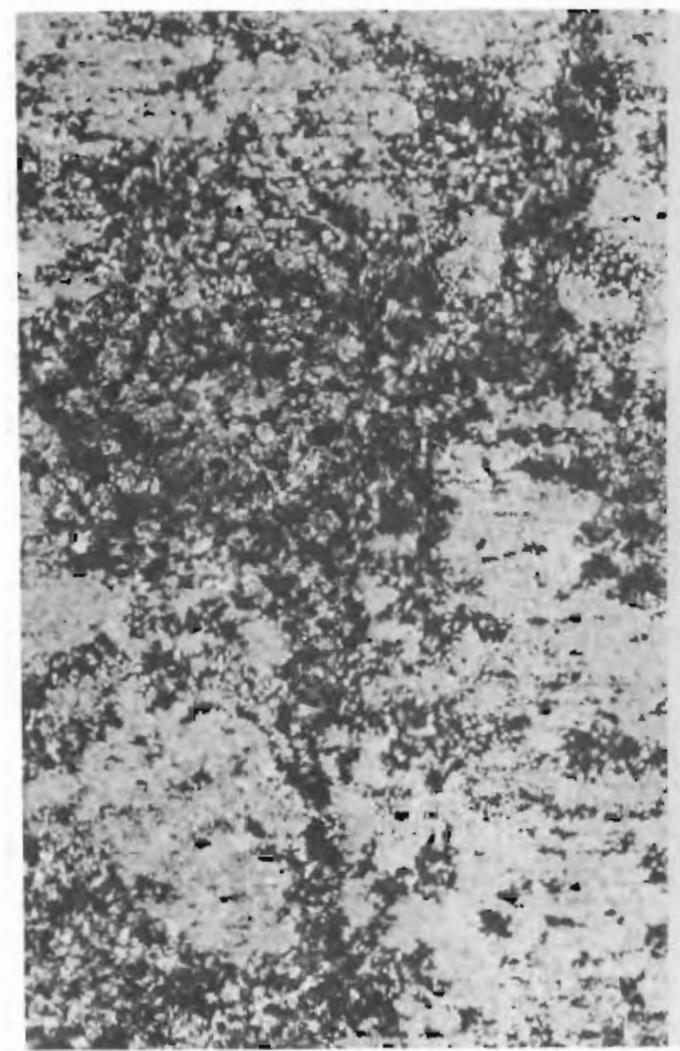

Side Next to Electrode

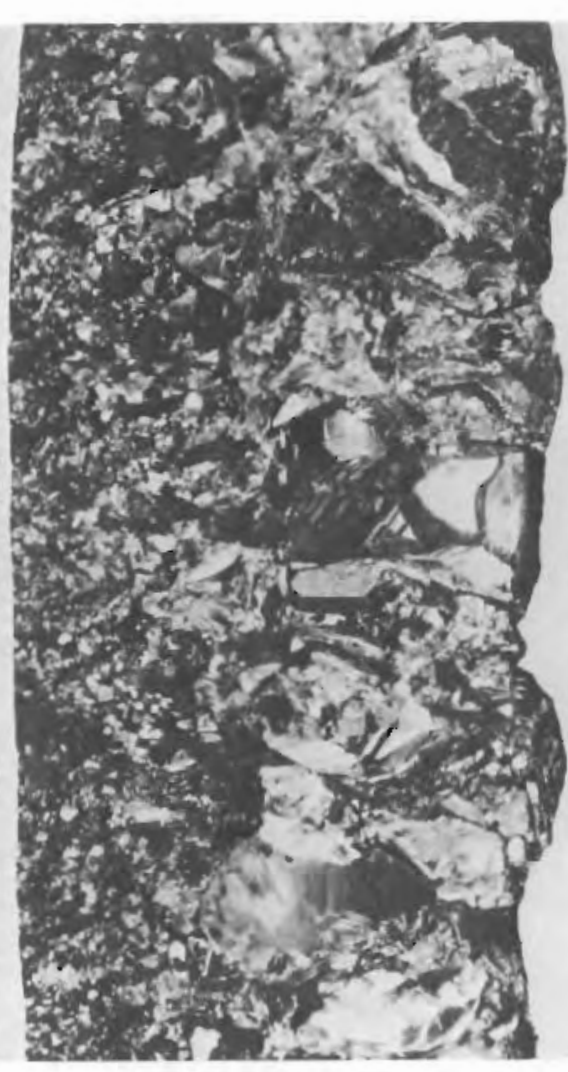

Cross Section

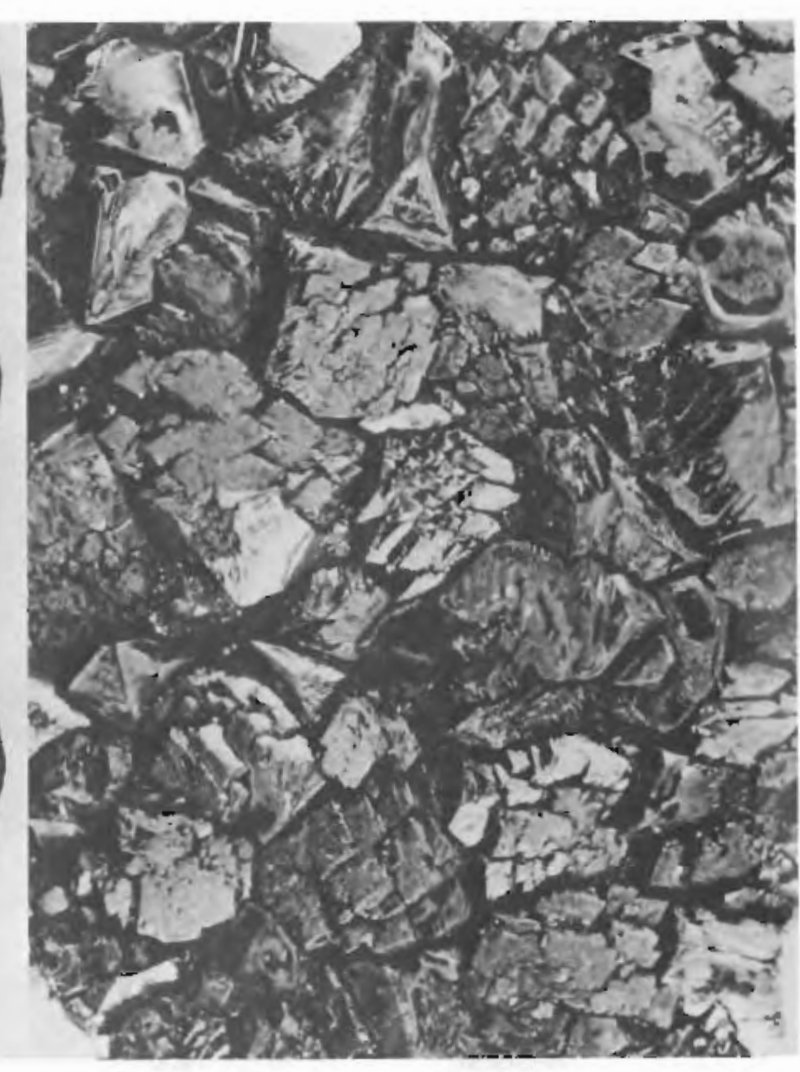

Growing Surface

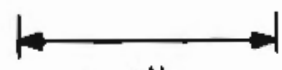

$0.1^{11}$

FIGURE 23

Cross Section of $\mathrm{UO}_{2}$ Deposit from $\mathrm{PbCl}_{2}-2.5 \mathrm{KCl}$ Salt Bath Run NPL-6, O/U Ratio $=2.015$ 


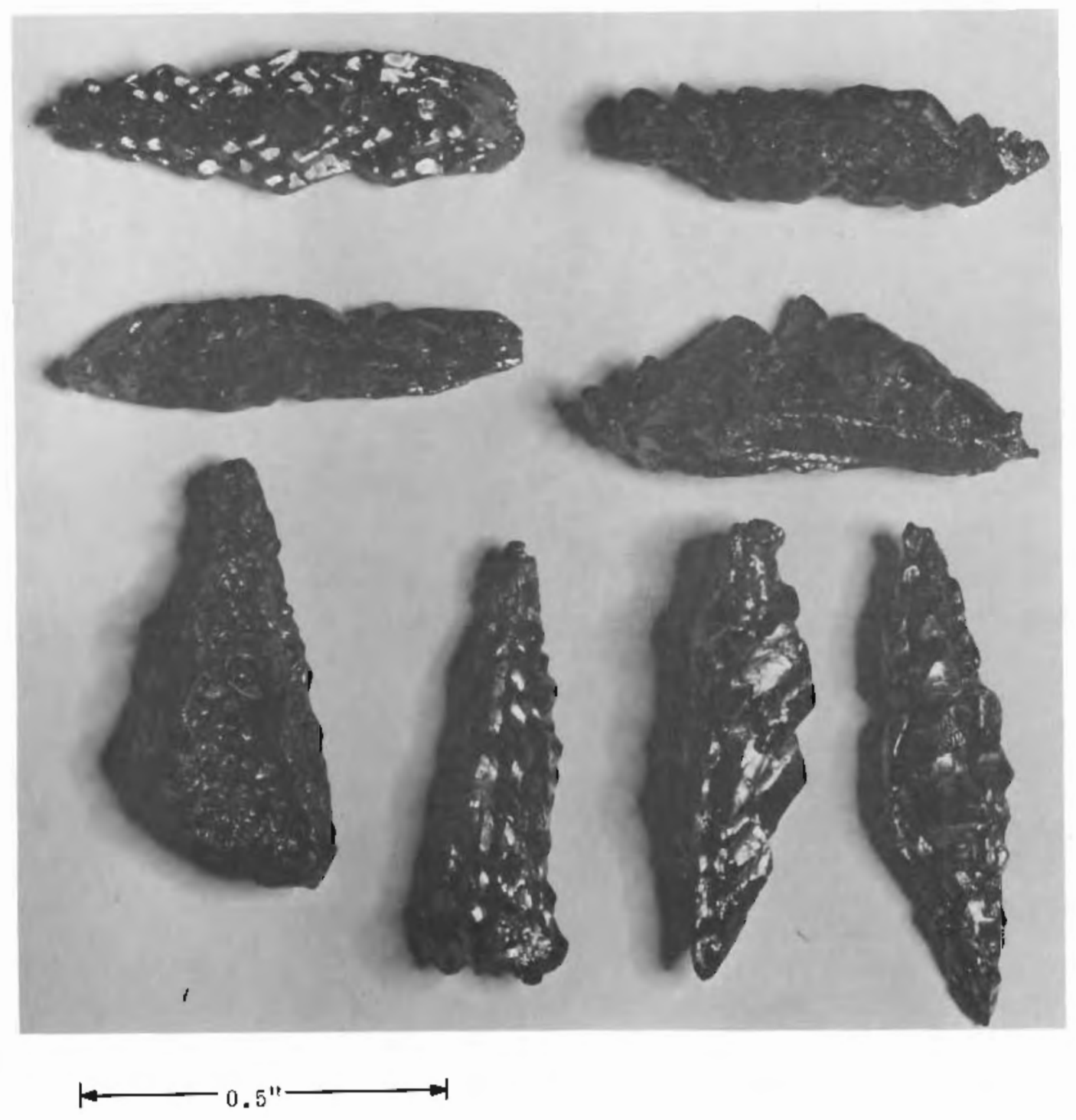

FIGURE 24

Mace-Type Crystals from the $\mathrm{PbCl}_{2}-2.5 \mathrm{KCl}$ Salt Bath Run NPL-14 O/U Ratio $=2.09$ 
Salt System: 2.5 moles $\mathrm{KCl} / \mathrm{mole} \mathrm{PbCl}_{2}$
Total Salt Weight: 482 to $658 \mathrm{lb}$

Feed Material: $U_{0} \mathrm{O}_{8}$ powder
Cathode: Hastelloy $D$

Cathode: Hastellioy $D$ D
Anode: Two flat carbon anodes with a
total submerged area of 110 in $^{2}$

$\frac{\text { Feed Weight, } 1 \mathrm{~b}}{\text { Initial1y in } \mathrm{U}_{3} \mathrm{O}_{8}}$ Moles $\mathrm{Cl}_{2}$ Used/ Time, Average Flow, Time, Maximum Ref. Potential, Temp, wt\% U, Current Densitis,

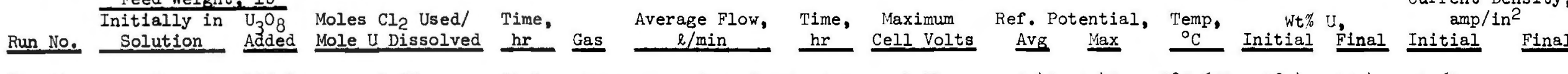

NPL-14

$37.8 \quad 100.0$

1.45

14.5 Concurrent with dissolution

2.75

$\begin{array}{llllll}0.40 & 0.41 & 583-600 & 21.4 & 1.46 & 0.75\end{array}$

$16.6 \mathrm{HC1}$

$\begin{array}{lll}5.4 & 5.8 \quad 1.52\end{array}$

$\begin{array}{lllllll}0.26 & 0.41 & 555-580 & 20.7 & 5.50 & 0.42\end{array}$

$\begin{array}{llllll}0.32 & 0.34 & 600-620 & 13.7 & 6.72 & 0.89\end{array}$

$\begin{array}{llllll}0.35 & 0.37 & 590-600 & 22.7 & 9.14 & 0.92\end{array}$

$\begin{array}{llllll}0.44 & 0.46 & 580-650 & 23.8 & 18.0 & 1.20\end{array}$

$\begin{array}{llllll}0.43 & 0.51 & 587-620 & 29.5 & 18.0 & 0.46\end{array}$

$\begin{array}{lllllll}0.46 & 0.49 & 570-620 & 34.0 & 28.2 & 0.33\end{array}$

$\begin{array}{llllllll}0.58 & 1.12 & 600-620 & \ldots & 32.3 & 0.44 & 0.55\end{array}$ $\begin{array}{llll}\text { NPL-17 } & 17.9 \quad 125.0 \quad 1.71\end{array}$

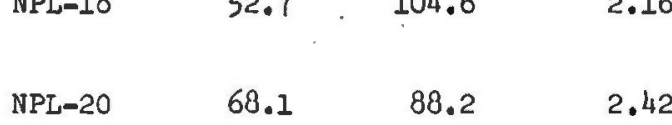

NPL-21* $\quad 85.0 \quad 95.6 \quad 5.44$

$\begin{array}{llll}\text { NPL-22 } & 133.0 & 96.0 & 3.09\end{array}$
86.3 Concurrent with dissolution $\quad 2.4$
TABLE X

Fighty Liter Salt Bath

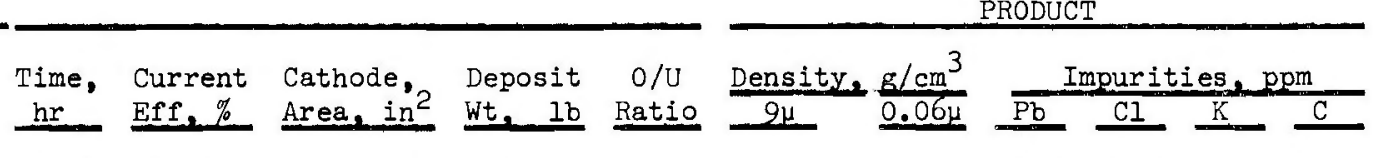

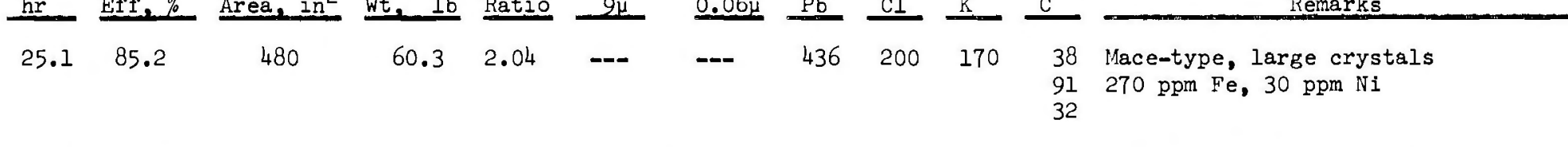
$48.0 \quad 87.6$

480 $\begin{array}{ll}348 & \text { Mace-type, large crystals } \\ 162 & 490 \mathrm{ppm} \text { Fe } \\ 128 & \end{array}$

$234.0 \quad 57.5$

$\begin{array}{llllllllll}480 & 82.0 & 2.13 & 10.37 & 10.81 & 622 & 354 & 300 & 1256 & \begin{array}{l}\text { Mace-type, fairly large crystals } \\ 400 \mathrm{ppm}\end{array}\end{array}$

$\begin{array}{llllllllllll}30.3 & 72.5 & 480 & 87.0 & 2.026 & 10.71 & 10.86 & 925 & 13 & 180 & \begin{array}{l}279 \\ 205\end{array} & \begin{array}{l}\text { Close packed dense outside, porous } \\ \text { sma11 grain on inside }\end{array}\end{array}$

$51.0 \quad 79.4$

$65.0 \quad 79.3$

$113.8 \quad 80.0$

96.6. 41.8

$50.3 \quad 48.1$

$\begin{array}{lllllllllll}444 & 86.0 & 2.028 & 10.72 & 10.86 & 592 & 300 & 400 & ---\begin{array}{l}\text { Compact dense on outside, powdery } \\ \text { deposit inside }\end{array}\end{array}$

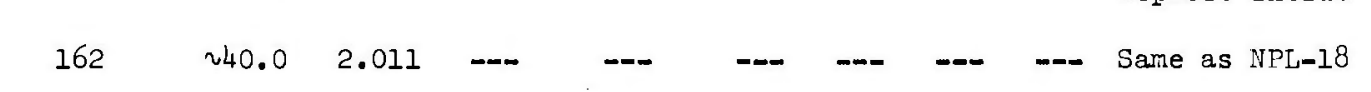

$\begin{array}{llllllllll}372 & 45.2 & 2.004 & 9.92 & 10.34 & 1600 & 200 & 210 & --- & \text { compact, dense, very good }\end{array}$

$\begin{array}{lllllllllll}372 & 41.0 & 2.040 & 8.85 & 9.75 & 594 & 6000 & 3000 & \ldots & \ldots & \text { Poxdery, fine, 10osely agglonerated }\end{array}$

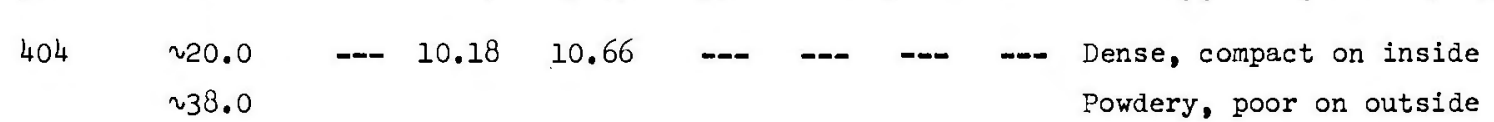


After it was established that $\mathrm{UO}_{2}$ could be produced on a large scale in the $2.5 \mathrm{KCl}-\mathrm{PbCl}_{2}$ system, further efforts were made to lower the oxygen-to-uranium ratio of the product. Laboratory-scale studies had indicated that a dry melt and a chlorine atmosphere were conditions necessary to produce low oxygen-touranium ratio $\mathrm{UO}_{2}$. Consequently, the drying methods discussed earlier were tested, and operation with a reduced air sweep over the melt was tried. The oxygen-to-uranium ratios were reduced to as low as 2.011 by these methods. However, the 8-hr/day operation during dissolution and drying did not lead to complete melt drying before electrolysis. Normally a small layer of powdery $\mathrm{UO}_{2}$ was found near the electrode surface, with a dense layer of large $\mathrm{UO}_{2}$ crystals comprising the remainder of the deposit. Since the electrolysis was a 24-hr/day operation, the melt was evidently dried by the chlorine from the anode reaction, accounting for the good outer layer.

A combination of changes was made simultaneously including (1) the developmentiof a lid separating the crucible atmosphere into a lower chlorine zone and and upper zone containing the off-gas outlet and having atmospheric air inleakage, (2) 24-hour operation during dissolution and drying, and (3) the use of a method for determining melt dryness developed by Chemical Research personnel. These changes resulted in the electrodeposition of a dense, large crystal $\mathrm{UO}_{2}$ product (Run NPL-21) having an oxygen-to-uranium ratio of 2.0036 . This deposit left little doubt that the laboratory results could be scaled up to production size operation with proper equipment design.

Two further runs, NPL-22 and 23 were made in $2.5 \mathrm{KCl}-\mathrm{PbCl}_{2}$ system which resulted in rather poor product. The cyrstal size was small and did not resemble any from the earlier runs. The poor results were attributed to impurities in the feed after similar results were observed in later electrolyses in the $\mathrm{LiCl}-\mathrm{KCl}$ system. The feed was found to contain 1 wt\% iron in addition to other impurities. It was later found that corrosion of the Hastelloy $D$ cathode could also have contributed to the poor results. Product Evaluation

The evaluation of the product for use as reactor grade $\mathrm{UO}_{2}$ included determination of density, impurity content, oxygen-to-uranium ratio, and minimum 
crystal size. Crystal size was generally adequate for high density vibratory compaction and, therefore, was only qualitatively evaluated for each run.

The available data for the product are show in Tables IX (see page 55) and $X$ (see page 63). The density, reported for $-6+20$ mesh particles, was measured with a mercury porosimeter with all open pores less than 9 diam considered as part of the $\mathrm{UO}_{2}$.

The major impurities in the product from the $2.5 \mathrm{KCl}^{-\mathrm{PbCl}_{2}}$ system were lead, chloride, and potassium with some iron and silicon. The lead and potassium were apparently occluded as salts. The soluble potassium chloride was rather eqsily removed with water but the lead chloride was difficult to remove even with the use of hot $0.5 \mathrm{M}$ ethylenediaminetetraacetic acid (TDTA). Because of its greater weight and difficulty of removal, lead made up the bulk of impurities. In the pilot plant studies, the lowest concentration of lead in the product was $440 \mathrm{ppm}$. In previous laboratory studies, lead had been removed to as low as $50 \mathrm{ppm}$, indicating that with further development work the lead content of the pilot plant product could have been reduced. (25)

The crushing and washing of the product from the pilot plant were investigated only as a sidelight in the transfer of the $\mathrm{UO}_{2}$ to Ceramics Fuel Development personnel for evaluation. The $\mathrm{UO}_{2}$ was crushed in a faw mill to -6 mesh and then washed in a packed bed through which 0.1 II EDTA solution was circulated. The lead removal increased with increasing washing temperature and EDTA concentration of the wash solution. Since most of the early pilot plant product had an $O / U$ ratio above the specification of 2.015 , a hydrogen reduction to lower the oxygen was made by Ceramics Fuel Development personnel. In the process, lead, lead chloride, and potassium chloride impurities were volatilized, appreciably decreasing the lead impurity content as shown in Table XI. (25)

\section{TABLE XI}

\section{WFFECT OF HYDROGEN TREATITIST FOR 10 HOUR:' AI' 1000 "C}

\section{ON SALT CONTEENT OF ELECTRODEPOSITED UO}

$\begin{array}{lrrrr} & \text { ppm K } & \text { ppm Pb } & \text { ppm Cl } & \frac{0 / U \text { Ratio }}{1,400} \\ \text { As electrodeposited-unwashed } & 12,100 & 1,100 & 2.013 \\ \text { After } \mathrm{H}_{2} \text { treatment at } 1000^{\circ} \mathrm{C} & 360 & .250 & 65 & 2.001\end{array}$




\section{LITHIUM CILORIDE-POTASSIUM CHLORIDE PILOT PLANT OPERATIONS}

Lithium chloride-potassium chloride was the last of the systems investigated because of the highly hygroscopic nature of LiCl systems. LiCl, when exposed to the atmosphere at room temperature, absorbs water until an aqueous solution is formed. Laboratory studies by Chemical Research personnel showed, however, that even in this system the moisture which prevents deposition of stoichiometric $\mathrm{UO}_{2}$ can be removed by sparging with hydrogen chloride or chlorine. The hygroscopic nature of this system increases strongly as the LiCl content is increased, and operations in pure LiCl would require much greater care in excluding the atmosphere than in equimolar LiCl-KCl. The advantages of the $\mathrm{LiCl}-\mathrm{KCl}$ system over the $\mathrm{PbCl}_{2}-\mathrm{KCl}$ system are:

- The system can be operated at a lower temperature. Pilot plant dissolutions of $\mathrm{U}_{3} \mathrm{O}_{3}$ were conducted in the $\mathrm{LiCl}-\mathrm{KCl}$ eutectic at $600^{\circ} \mathrm{C}$ and electrolyses were carried out at as low a temperature as $500{ }^{\circ} \mathrm{C}$, versus $700{ }^{\circ} \mathrm{C}$ and $600{ }^{\circ} \mathrm{C}$, respectively, for the $\mathrm{PbCl}_{2}-$ $\mathrm{KCl}$ system。

- The LiCl-KCl system is essentially nonvolatile under these conditions, with a boiling point of $1400{ }^{\circ} \mathrm{C}$. The $\mathrm{PbCl}_{2}-\mathrm{KCl}$ system produced $\mathrm{PbCl}_{2}$ vapors which clogged off-gas lines。

- LiCl and $K \mathrm{Cl}$ have high decomposition potentials, so that they are not readily codeposited with the $\mathrm{UO}_{2}$ and the occluded salt can readily be removed from the deposit by water washing. $\mathrm{PbCl}_{2}$ was not readily soluble in water, and even extensive washing with complexing agents at elevated temperatures could not lower the lead content to acceptable limits. The low decomposition potential limited the range of operation of the process without depositing lead。

- The wide range of operating temperatures and solvent compositions in $\mathrm{LiCl}-\mathrm{KCl}$ allows the carrying out of related processes such as precipitation, partition and codeposition which require higher operating temperatures or widely varying chloride activities。

A total of $510 \mathrm{lb}$ of $\mathrm{UO}_{2}$ was produced in 9 runs in the 80 liter pilotplant quartz pot with 60 wt\% $\mathrm{KCl}-40$ wt\% LiCl(46 mol\% $\mathrm{KCl}-54 \mathrm{~mol} \% \mathrm{LiCl}$ )。 The results are reported in Table XII, Dissolution of $\mathrm{U}_{3} \mathrm{O}_{8}$ and drying of the melt were carried out at $600^{\circ} \mathrm{C}$ in each case.

Dissolution and Drying in the 80 Liter Salt Bath

To ensure dryness of the melt the dual lid system described under the Equipment Section, page 47, was used throughout the LiCl-KCl pilot-plant 
PILOT PLANT ELECTROLYSES IN THE LITHTUM CHLORIDE-POTASSIUM CHLORIDE SYSTEM

Eighty Liter Salt Bath Containing Equflmolar LiC1-KCl

Dissolution Temperature: $600^{\circ} \mathrm{C}$

Gas Lift Flow Rate: $4 \mathrm{l} / \mathrm{min}$ chlorine

DISSOLUTION

DRYING

ELECTROLYSIS

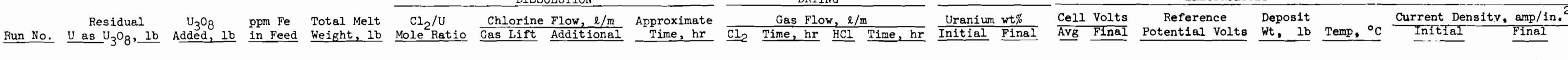

\begin{tabular}{|c|c|c|c|c|c|c|c|c|c|c|c|c|c|c|c|c|c|c|c|c|}
\hline LK-24 & None & 110.1 & High & 388 & 9.6 & 3.2 & 3.0 & 150. & $6 * *$ & 4 & --- & --- & 20.0 & 10.9 & --- & 2.13 & 0.74 & 39.3 & $515-520$ & 0.90 \\
\hline LK-25* & 52 & 57.8 & High & 387 & 10.5 & 4.3 & 1.8 & 71. & 3** & 51 & --- & --- & 20.3 & 11.3 & --- & 2.00 & 0.32 & 36.0 & $360-560$ & 0.33 \\
\hline LK-26 & None & 130. & 170 & 345 & 10.2 & 3.5 & 3.0 & 144. & $4 * * *$ & 23 & 2.0 & 59. & 29.8 & 12.5 & -- & 2.40 & 0.77 & 82.1 & $510-540$ & 0.62 \\
\hline $\mathrm{L} K-2 T^{*}$ & 45 & 100. & --- & 360 & 6.7 & 4.0 & 3.0 & --- & $6 * * *$ & 23 & 2.0 & 2.5 & 32.2 & 20.4 & --- & 2.00 & 0.77 & 62.5 & $470-540$ & 0.60 \\
\hline LK-28* & 80 & 50. & 5302 & 345 & 5.0 & 3.0 & 3.0 & 66. & 3 & 19 & 2.0 & 14.0 & 28.2 & (16.7) & 1.97 & 2.42 & 0.76 & 48.0 & $500-535$ & 0.54 \\
\hline LK-29* & 58 & None & $270 ?$ & 295 & --- & -- & --- & --- & 3 & 16 & 1.5 & 24. & $(16.7)$ & 5.3 & 1.30 & 1.38 & 0.48 & 50.0 & 535 & 0.46 \\
\hline LK-30 & None & 130. & 60 & 345 & 5.6 & 4.4 & 3.0 & 48 & 3 & 38 & 2.0 & 4. & 29.4 & 14.5 & 2.30 & 2.40 & 0.88 & 73.0 & 535 & 0.95 \\
\hline LK-31* & 54 & 80. & 50 & 349 & 3.8 & 4.4 & 3.0 & 26.5 & 4 & 6 & 2.5 & 6. & 26.3 & 17.9 & 1.25 & 1.38 & 0.51 & 44.5 & 530 & 0.64 \\
\hline LK-32* & 90 & 41. & --- & 340 & 5.1 & 4.2 & 3.0 & 31. & 4 & 38 & 1.0 & 10. & 25.8 & 10.4 & 2.5 & 6.0 & -- & 75.0 & 535 & 0.80 \\
\hline
\end{tabular}

\begin{tabular}{|c|c|c|c|c|c|c|c|c|c|c|c|c|c|}
\hline \multirow[b]{2}{*}{ Run No. } & \multicolumn{3}{|c|}{ ELECTROLYSIS } & \multicolumn{8}{|c|}{ PRODUCT } & \multirow[b]{2}{*}{ Crystal Characteristics } & \multirow[b]{2}{*}{ Remarks } \\
\hline & $\begin{array}{c}\text { Current } \\
\text { Efficiency }\end{array}$ & $\frac{c}{\text { Area, } \text { in. }^{2}}$ & $\begin{array}{l}\text { Cathode } \\
\text { Material }\end{array}$ & $0 / U$ Ratio & $\overline{\mathrm{Li}}$ & $\frac{\mathrm{ppm}}{\mathrm{K}}$ & $\frac{\text { Impur: }}{\mathrm{C}}$ & & $\mathrm{Fe}^{-}$ & $\frac{\text { Densit }}{94}$ & $\frac{1,8 / \mathrm{cm}^{3}}{0.06 \mu}$ & & \\
\hline LK-24 & 60 & 368 & Carbon & 0.0266 & 110 & 240 & 91 & -.- & 226 & 10.65 & 10.80 & Walnut, small. & $0.3 \mathrm{wt} \% \mathrm{Fe}$ in melt. \\
\hline LK-25* & 49 & 515 & HastelloyD & 2.0530 & 60 & -- & 14 & 245 & --- & 10.51 & 10.92 & Powdery next to cathode, outside dendritic. & $\begin{array}{l}0.3 \text { wt\% Fe in melt. Melt became wet during a heater shutdown in } \\
\text { the run. }\end{array}$ \\
\hline LK-26 & 73 & 374 & Hastelloy $D$ & 2.0037 & 70 & 23 & -- & --- & 125 & 10.85 & 10.88 & Very large, dense, flat large faced crystals. & \\
\hline LK-27* & 74 & 380 & Hastelloy D & 2.0050 & 30 & --- & -- & --- & 115 & 10.11 & 10.62 & $\begin{array}{l}\text { Blistered, splotchy deposit bare oxidized cath- } \\
\text { ode in spots. Fairly large, flat crystal. }\end{array}$ & \\
\hline LK-28* & 62 & 390 & Duranickel $\dagger$ & $\begin{array}{l}2.0048(\text { Metal) } \\
2.0071 \text { (Carbon }\end{array}$ & -- & --- & 74 & 350 & 92 & 10.38 & 10.55 & Small, dense and flat. & $\begin{array}{l}\text { Initial melt contained } 0.25 \mathrm{wt} \% \mathrm{Ni} \text { from corrosion of electrode in } \\
\text { Run } 27 \text { and contained } 0.54 \mathrm{wt} \% \mathrm{Ni} \text { at the end of electrolysis. }\end{array}$ \\
\hline LK-29* & 70 & 263 & Carbon & 2.0107 & -- & -- & -- & -- & 185 & 10.85 & 10.90 & Very thin, walnut, columnar. & $\begin{array}{l}\text { Melt contained } 0.52 \text { wt\% Ni from electrode corrosion during } \\
\text { Run } 28 \text {. }\end{array}$ \\
\hline LK-30 & 76 & 315 & Carbontt & 2.0023 & -- & --- & 116 & --- & 120 & 10.79 & 10.84 & Thin, columnar, almost walnut. & $60 \mathrm{ppm}$ Fe in salt. \\
\hline LK- $31 *$ & 75 & 280 & Carbontt & 2.0006 & --- & --- & 253 & 4 & 140 & & & Medium, small, columnar. & $60 \mathrm{ppm}$ Fe in salt. \\
\hline LK-32* & --- & 289 & Carbontt & 2.0025 & -- & --- & 285 & --- & 170 & 10.78 & 10.87 & $\begin{array}{l}\text { Dense, columnar near cathode turning to soft } \\
\text { and spongy on outside. }\end{array}$ & $\begin{array}{l}\text { Constant current run. Feference potential exceeded salt decomposi- } \\
\text { tion voltage near end of run. } 90 \text { ppm Fe, } 40 \mathrm{ppm} \mathrm{Ni} \text { in salt. }\end{array}$ \\
\hline
\end{tabular}

*Salt bath from previous run was used as the starting material for this run.

**During preelectrolysis.
$* * *$ Anodes predried in oven.

+Protected by graphite at interface
t+Hand polished pile graphite. 
runs. The dryness testing apparatus was employed after each dissolution to determine whether the bath was ready for electrolysis. During trial operation in the first run $(\mathrm{LK}-24)$ in the LiCl-KCl salt bath a gas-lift recirculator was found qualitatively to fluidize the $\mathrm{U}_{3} \mathrm{O}_{8}$ powder much better than straight sparge tubes. In all LiCl-KCl pilot plant runs the dissolution of $\mathrm{U}_{3} \mathrm{O}_{8}$ was carried out with a gas-lift recirculator using chlorine, with additional chlorine introduced into the melt with straight sparge tubes.

In the initial run $(L K-24)$ the bath was dried with chlorine for several hours before $110 \mathrm{Ib}$ of $\mathrm{U}_{3} \mathrm{O}_{8}$ were introduced in 4 batches over a $27 \mathrm{hr}$ period. Chlorine was sparged intermittently into the bath with the gas-lift system until the dryness test showed a small positive slope (not quite dry). Then graphite electrodes were inserted and the bath was pre-electrolyzed for $5 \mathrm{hr}$. The dryness test then indicated no increase in current with time, so that the salt was ready to electrolyze. The $0 / U$ ratio of the product was 2.027 , indicating that the bath was not completely dry. The crystal structure was poor, and this was tentatively attributed to the iron in the feed.

A second run ( $\mathrm{LK}-25$ ) was made with the same melt as above. $\mathrm{U}_{3} \mathrm{O}_{8}$ was added to the melt to replace the $\mathrm{UO}_{2}$ deposited. The bath was then sparged continuously with chlorine for $80 \mathrm{hr}$. The dryness test indicated a very dry melt. A pre-electrolysis with graphite electrodes was then carried out for $6 \mathrm{hr}$ at $1.6 \mathrm{~V}$ and $210 \mathrm{amp}$ at $520^{\circ} \mathrm{C}$. The graphite electrodes introduced some water into the melt as shown by foaming and spattering of the bath during introduction of the electrodes. However, a subsequent dryness test indicated the melt was nearly dry. During the.subsequent electrolysis with a Hastelloy $D$ cathode, power was accidentally cut off allowing the bath to cool. Before power resumption a crust had formed on top and the electrodes froze, interrupting the electrolysis for at least one hour. Since the chlorine blanket produced by the electrolysis was not present during this period the external atmosphere penetrated to the salt bath and moisture was picked up by the bath. The electrolysis was continued, but the damage had already been done and the average $\mathrm{O} / \mathrm{U}$ ratio of the deposit was 2.053 .

Because of the iron introduced by the impure feed, the salt from runs LK-24 and 25 was discarded and a fresh salt bath was used in Run LK-26. About 
130 lb of $\mathrm{U}_{3} \mathrm{O}_{8}$, charged in several small batches, wais dissulved by sparging with chlorine gas continuously for $120 \mathrm{hr}$ followed by drying with HCl gas for $16 \mathrm{hr}$. The dryness test showed a dry melt and the electrolysis was carried out with electrodes which had been predried at $100^{\circ} \mathrm{C}$ for $24 \mathrm{hr}$ 。 The oxygen-to-uranium ratio of the product was 2.0037 and the crystal structure was ideal, indicating that adequate dissolution of the $\mathrm{U}_{3} \mathrm{O}_{8}$ and drying had been attained. A continuous sparge of chlorine or hydrogen chloride is necessary to prevent even the molten salt from reabsorbing moisture from the atmosphere. All subsequent runs were carried out in a similar manner to run LK-26. The $0 / U$ ratio varied from 2.006 to 2.0107 in these runs, averaging well below the desired maximum ratio of 2.01 。

In an effort to reduce the excess of chlorine needed and to seek a minimum time cycle for dissolution and drying, a 24-hr dissolution test was carried out in Run $\mathrm{LK}-31$ at $600^{\circ} \mathrm{C}, \mathrm{U}_{3} \mathrm{O}_{8}$ feed was added in two $30-1 \mathrm{~b}$ increments at zero and $8 \mathrm{hr}$ and a 20-1b increment at $16 \mathrm{hr}$. The $\mathrm{U}_{3} \mathrm{O}_{8}$ slurry was circulated through the gas lift by chlorine and additional chlorine was introduced through a sparge tube. In Figure 25 the results of this test are compared with the dissolution in Run LK-30。 Drying was carried out with two carbon rods in place using hydrogen chloride and chlorine at $530^{\circ} \mathrm{C}$ 。

The rate of dissolution was, of course, most rapid after each incremental $\mathrm{U}_{3} \mathrm{O}_{8}$ addition, with little $\mathrm{U}_{3} \mathrm{O}_{8}$ left to dissolve in the last $4 \mathrm{hr}$ of each $8-\mathrm{hr}$ period. From Figure 25 it appears that with continuous addition or with properly timed increments the dissolution could be completed in less than $12 \mathrm{hr}$. Drying was complete in less than $4 \mathrm{hr}$, but examination of the dryness test curve indicated that $2 \mathrm{hr}$ would be sufficient, making a 12 - to 14-hr dissolution-drying time cycle probable.

The effectiveness of dissolution and drying can be determined adequately for control purposes by the dryness test conducted before electrolysis. Crystal structure although influenced profoundly by the $O / U$ ratio is also influenced by electrolysis conditions, electrode composition, and impurities in the bath. Final proof of the adequacy of dissolution, drying, and atmosphere control is given only by the oxygen-to-uranium ratio of the product. 


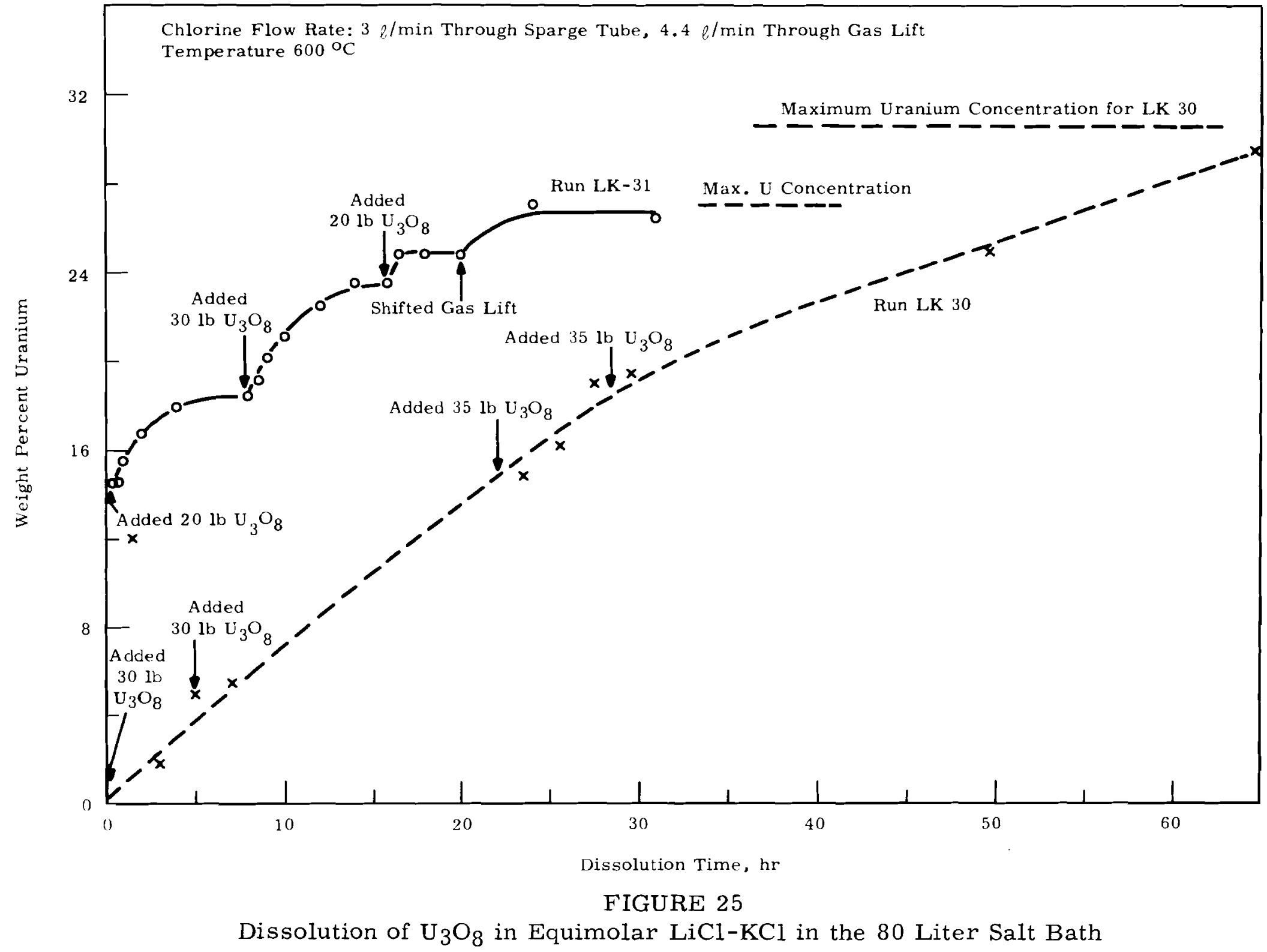


Electrolysis and Product Evaluation from 80 Liter Pilot Plant Runs

Electrolyses in the $\mathrm{KCl}-\mathrm{LiCl}$ system were carried out at $530^{\circ} \mathrm{C}$, with deviations as noted in Table XII. The atmosphere was chlorine produced at the anode and contained by the dual lid system developed in the $\mathrm{PbCl}_{2}-\mathrm{KCl}$ runs. The influence of the imposed electrolytic conditions on the $\mathrm{UO}_{2}$ product was masked in Runs LK-24 and LK-25 by the wetness of the melt and in subsequent runs by impurities in the system introduced by the feed and by corrosion of electrodes. The crystal structures produced in these runs are shown in Figures 26 and 27 .

In Run LK-24 the electrolysis was carried out at an average reference potential of 0.74 volts and a current density of 0.85 to $0.90 \mathrm{amp} / \mathrm{in}^{2}$ with electrodes made of reactor grade graphite. The product had a high $0 / 0$ ratio (2.027) but a relatively high density with small crystals. A lower reference potential of 0.32 volts and a Hastelloy $D$ cathode were used for Run LK-25 but the deposit was dendritic because of moisture introduced by poor atmosphere control during a heater shutdown.

Examination of the portion of the deposit next to the electrode, which was deposited before the operating difficulties occurred, revealed a powdery mass similar to that in LK-24. Analysis of the feed for these runs showed 0.35 wt\% iron, and the deposits for runs $\mathrm{LK}-24$ and 25 contained 230 and 380 ppm iron, respectively. The poor crystal structure could then be due to either the wetness of the melt or the iron impurities. In the subsequent runs feeds containing about $100 \mathrm{ppm}$ iron were used, and all melts were sufficiently dry so that the drying and dissolution did not affect the product quality.

The electrolysis for Run LK-26 was carried out with a Hastelloy D cathode at a reference potential of 0.77 volts and a maximum current density of $0.62 \mathrm{amp} / \mathrm{in}$. The average production rate during the 48-hour electrolysis was $1.7 \mathrm{lb} / \mathrm{hr}$ at a current efficiency of $73 \%$. Even though the Hastelloy D was protected cathodically it corroded somewhat beneath the deposit, producing a thin corrosion layer. The deposit was composed of large, dense crystals with flat growing faces and had an O/U ratio of 2.0037 . Run LK-27 was made under the same conditions. The same Hastelloy D cathode was reused; a

(R) Union Carbide Company 


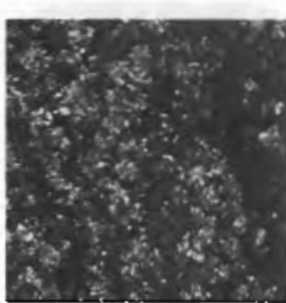

Run LK-24

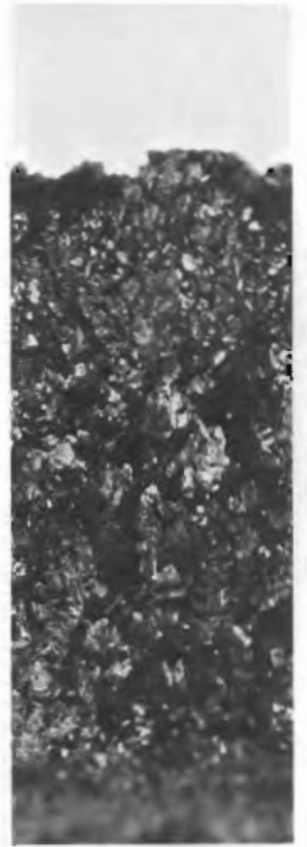

$\mathrm{O} / \mathrm{U}=2.027$

Wet Melt Graphite Cathode

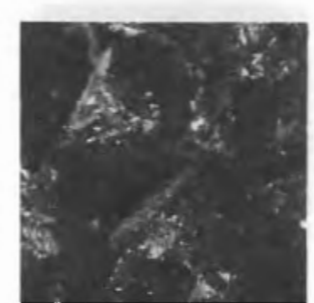

Run LK-25
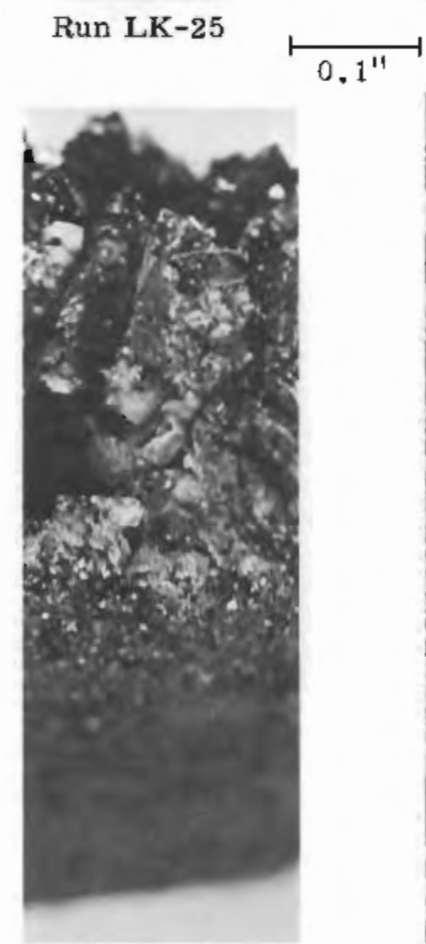

$\mathrm{O} / \mathrm{U}=2.053$

Wet Melt

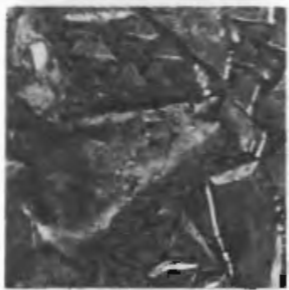

Run LK-26

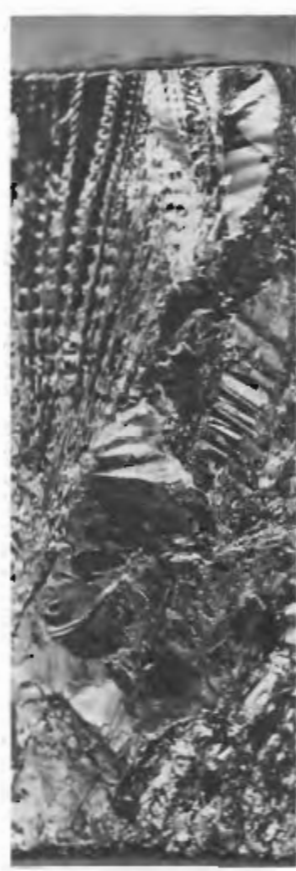

$\mathrm{O} / \mathrm{U}=2.004$

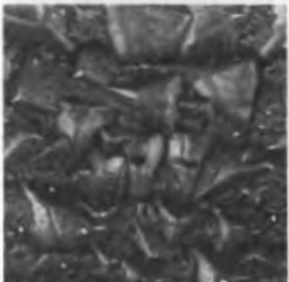

Run LK-28

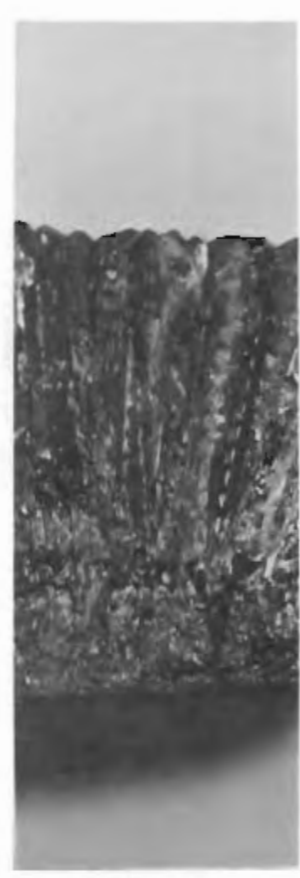

$\mathrm{O} / \mathrm{U}=2.005$

Severe Corrosion

FIGURE 26

$\mathrm{UO}_{2}$ Deposits on Hastelloy D Cathodes from 80 Liter LiCl-KCl Salt Baths 


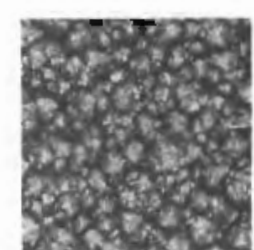

Run LK-29

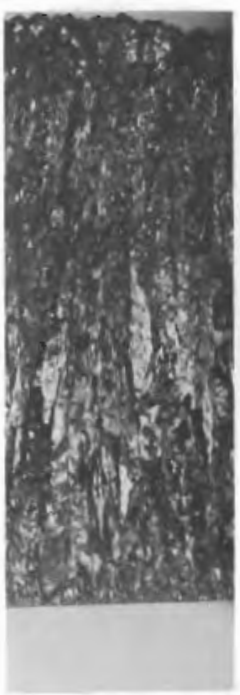

$\mathrm{O} / \mathrm{U}=2.011$

Accurnulated Corrosion Products in Bath from Earlier Hastelloy D Cathodes

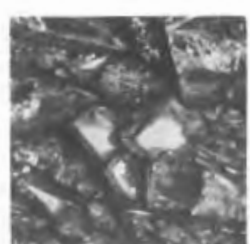

Run LK-30

$\underset{0.1^{11}}{\longrightarrow}$

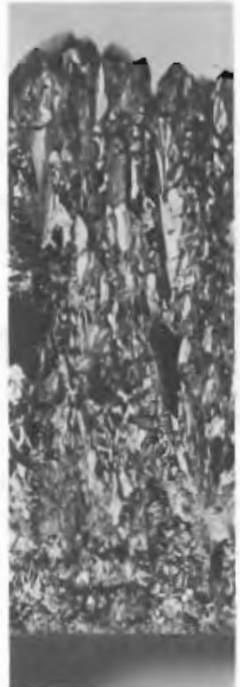

$\mathrm{O} / \mathrm{U}=2.002$

$$
\text { New Salt Bath }
$$

High Current Density

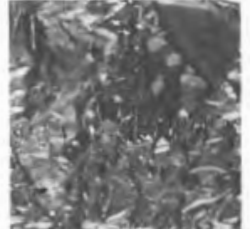

Run LK-31

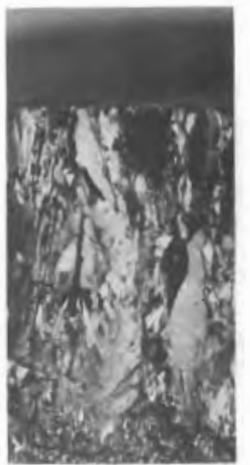

FIGURE 27

$\mathrm{UO}_{2}$ Deposits on Graphite Cathodes from 80 Liter LiCl-KCl Salt Baths

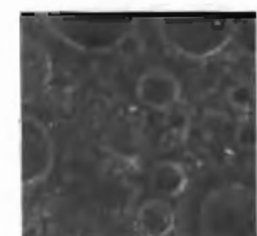

Run LK-32

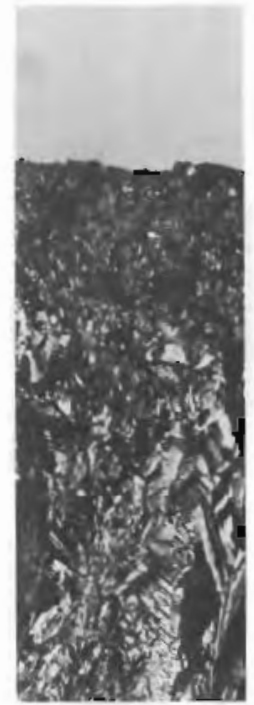

$\mathrm{O} / \mathrm{U}=2.003$

Constant Curren High Voltage at end of Run

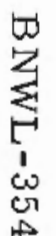


similar deposit was obtained except that the thickness varied considerably along the surface of the cathode with splotches of thick deposit surrounded by thinner layers of $\mathrm{UO}_{2}$. In some places the cathode was exposed completely and experienced considerable corrosion at these spots. It was concluded that the corrosion products had accumulated sufficiently on the cathode to reduce the current flowing in certain areas. The corrosion of Hastelloy $D$ is more severe in the $\mathrm{LiCl}-\mathrm{KCl}$ system than in the $\mathrm{PbCl}_{2}-\mathrm{KCl}$ system and the electrodes are unsuitable for reuse. After Run $\mathrm{LK}-27$ the melt contained 0.25 wt\% nickel from electrode corrosion. Run LK-28 was carried out with a Duranickel (P) cathode protected at the interface with a carbon slab which extended below the surface of the melt. The Duranickel was severely corroded particularly at the region directly below the graphite protector. This may have been due to an electrochemical interaction between the graphite and the Duranickel. At the beginning of this run the melt contained $0.25 \mathrm{wt} \%$ nickel and at the end it contained 0.54 wt\% nickel, all from corrosion of the electrodes, but the deposit contained only $350 \mathrm{ppm}$ nickel, which is a decontamination factor of about 50 from the initial uranium. The deposit that was produced consisted of relatively small crystals and Figure 26 shows that corrosion of the Duranickel certainly degraded the crystal structure of the deposit.

Run LK-29 was then made with graphite cathodes at a reduced reference potential of 0.48 , and beginning with the 16.7 wt\% $U$ terminal concentration of the previous run, the uranium concentration was lowered to 5.3 wt . A dense product was obtained but a walnut-type, small-crystal deposit resulted. Although a number of variables were changed, the poor crystal structure was tentatively attributed to the nickel present in the melt.

Because of the impurities, the melt was discarded and a fresh bath was electrolyzed in Runs LK-30 and 31. Carbon anodes were used in both runs, with the only major variable being the reference potential, which was 0.88 volts in Run $L K-30$ and 0.51 volts in Run LK-3l. The reduction in reference potential, accompanied by a reduced current density, did not affect the overall current efficiency, which was $75 \%$ in both runs. However, a much

(B) International Nickel Company 
smoother growing surface and a higher density at $9 \mu$ pore size was obtained at the lower reference potential $\left(10.618\right.$ versus $\left.10.825 \mathrm{~g} / \mathrm{cm}^{3}\right)$ 。The crystals were also somewhat larger in the low potential run. These runs also excluded reference potential as a prime factor in producing walnutatype deposits。

Run LK-32 was made at constant current. The crystals produced initially were unusually large and well defined (Figure 27)。 Toward the end of the run the reference potential exceeded the deposition potential of lithium and potasslum as is shown in Figure 28, This resulted in chaotically orlented small crystals with the growing surface containing many craters. The precise cause of these craters is not known, but the use of a very high reference potential or operation at constant total cell voltage can result in poor $\mathrm{UO}_{2}$ crystals because of deposition of alkali metals. In addition, lithium reacts with graphite with catastrophic corrosion. This did not occur here, apparently because the graphite was protected by the $\mathrm{UO}_{2}$ deposit covering it。

\section{Effect of Impurities on Deposit Crystal Structure}

Because of the poor crystal structure of the deposits produced with metallic cathodes and the apparently detrimental effect of impurities in the feed, a series of runs was made in a two liter crucible with controlled addition of various metallic impurities to the bath。 $(26)$ The results are reported in Table XIII。 The major differences in operating conditions between these tests and the pilot plant runs were the use of an HCl sparge and graphite electrodes during the electrolysis.

Nickel, a major component of the Hastelloy $D$ cathode, had no apparent effect on the deposit and a melt=tomdeposit decontamination factor (DF) of 3000 to 10,000 was obtained for nickel from uranium. Aluminum only had a DF of 10 to 20 and had a strongly detrimental effect on the $\mathrm{UO}_{2}$ crystalso Iron had a DF of 1000 and a weaker effect than aluminum. Manganese and the fission products zirconium, molybdenum, niobium and samarium had no apparent effect, Chromium tended to electropolish the deposit and had a DF of 1000 to 3000. The fission product molybdenum volatilized from the salt bath, apparently as the chloride。

These results indicate that impurities in the bath itself do not have as strong an effect on crystal structure as dynamic corrosion of the cathode. In 


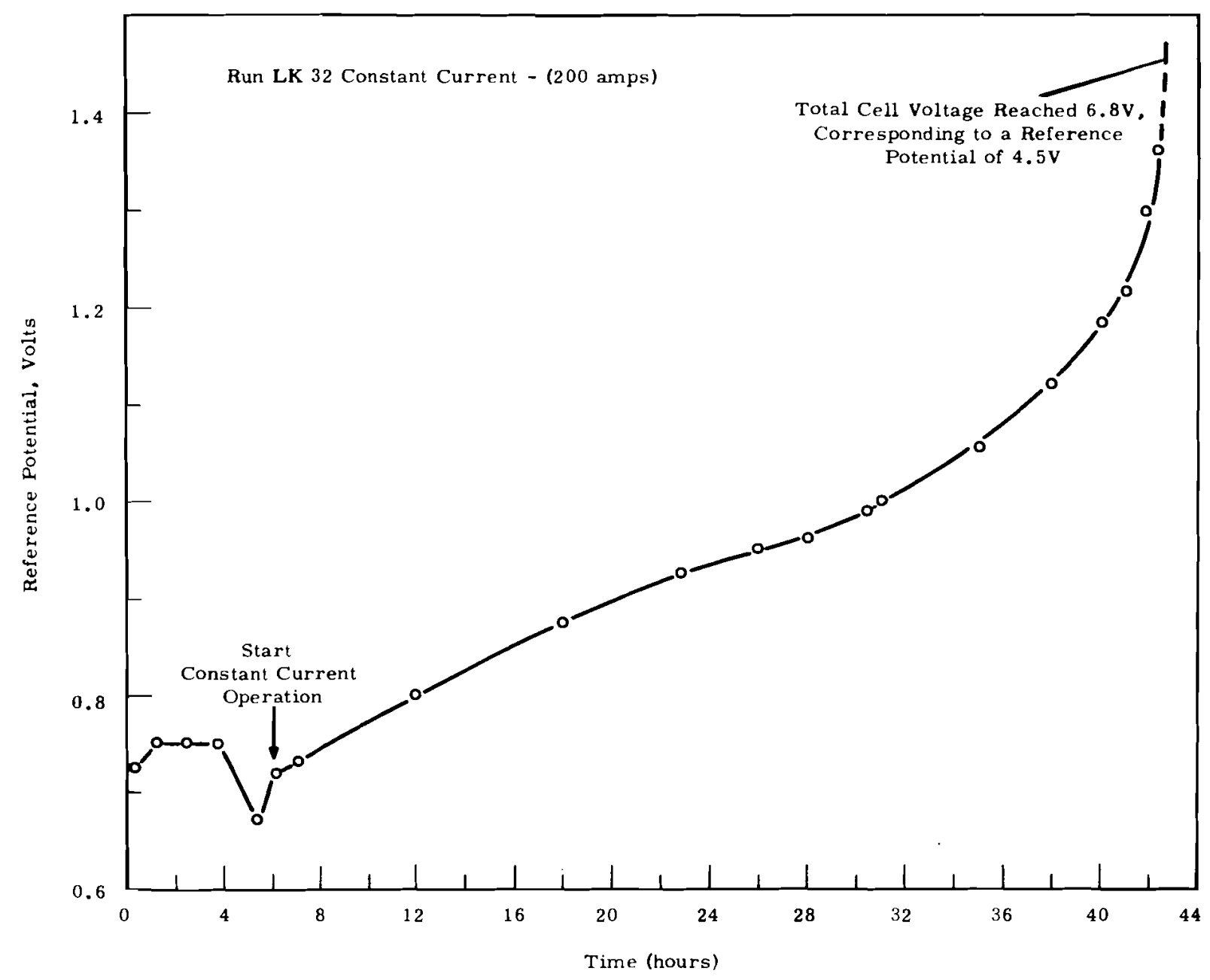

FIGURE 28

Reference Potential Variation in Constant Current Electrolysis 
TABLE XIII

EFFECT OF IMPURITIES ON ELECTROLYSES IN LITHIUM CHLORIDE - POTASSIUM CHLORIDE

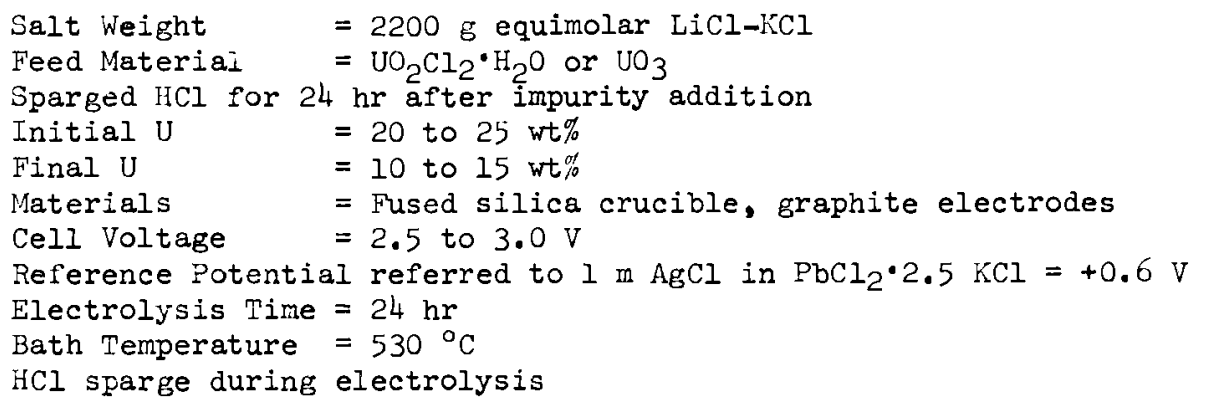

\begin{tabular}{|c|c|c|c|c|c|c|c|c|}
\hline Run No. & $\begin{array}{l}\text { Added } \\
\text { Chemical }\end{array}$ & $\begin{array}{l}\text { Wt \%etal } \\
\text { into Salt Bath }\end{array}$ & $\begin{array}{l}\text { ppm in } \\
\text { Deposit }\end{array}$ & DF & $\begin{array}{c}\text { Current } \\
\text { Efficiency }\end{array}$ & $\begin{array}{c}0 / U \\
\text { Ratio } \\
\end{array}$ & $\begin{array}{l}\text { Density, } \\
9 \mu \\
\end{array}$ & Remarks, Deposit Characteristics \\
\hline 2 & $\mathrm{Fe}^{\circ}$ & 1.0 & 120 & 1,000 & 60 & 2.0067 & 9.80 & Porous structure, melt was opaque due to $\mathrm{FeCl}_{3}$. \\
\hline 3 & None & -- & --- & -- & 94 & 2.0029 & 10.59 & Control. \\
\hline 4 & $\mathrm{Fe}^{\circ}$ & 1.0 & 100 & 1,000 & 61 & 2.0022 & 10.46 & $\begin{array}{l}\text { Highly electropolished, porous, small crystals. Fe caused a } \\
\text { reduced current efficiency. }\end{array}$ \\
\hline 6 & $\mathrm{Ni}^{\circ}$ & 0.79 & 4 & 11,000 & 90 & 2.0009 & 10.91 & No apparent effect. \\
\hline $7 *$ & $\mathrm{Al}^{\circ}$ & 0.1 & 200 Ni & $3,600 \mathrm{Ni}$ & 100 & 2.0015 & 10.83 & Very poor, porous deposit, small crystals. \\
\hline 8 & $\mathrm{Sm}_{2} \mathrm{O}_{3}$ & 0.42 & -- & -- & 94 & 2.0014 & 10.92 & No apparent effect. \\
\hline $9^{*}$ & $A I^{\circ}$ & 0.25 & 1200 & 9 & 81 & 2.0005 & 10.68 & Porous structure, precipitate. \\
\hline 10 & $\mathrm{AlCl}_{3}$ & 0.25 & -- & -- & 91 & $-\infty$ & 9.54 & $\begin{array}{l}\text { Porous structure, small crystals, precipitate - melt was opaque } \\
\text { after } \mathrm{Cl}_{2} \text { flow was interrupted for about } 2 \text { hours. }\end{array}$ \\
\hline 11 & $\begin{array}{l}\mathrm{Zr} \\
\mathrm{Nb}\end{array}$ & $\begin{array}{l}0.40 \\
0.40\end{array}$ & -- & -- & -- & 2.0021 & 10.80 & Large columnar crystals, deposit surface porous. \\
\hline 12 & $\mathrm{Nb}^{\circ}$ & 0.80 & $-\infty$ & -- & 76 & 2.0011 & 10.73 & No apparent effect - melt very deep red. \\
\hline 13 & $2 r^{\circ}$ & 0.40 & -- & -- & 100 & 2.0016 & 10.81 & No apparent effect. \\
\hline 14 & $\mathrm{CrO}_{3}$ & 0.40 & 7 & 3,100 & 108 & 2.0004 & 10.84 & $\begin{array}{l}\text { Highly electropolished surface, only } 10 \% \text { of } \mathrm{Cr} \text { found in salt, } \\
\text { melt was opaque after } \mathrm{HCl} \text { sparge started. }\end{array}$ \\
\hline $15 *$ & $\mathrm{Mo}^{\circ}$ & 0.74 & $20 \mathrm{Cr}$ & $\mathrm{r} 1,100 \mathrm{Cr}$ & 79 & 2.0019 & 10.32 & $\begin{array}{l}\text { Molybdenum volatilized as chloride, melt was brown and opaque } \\
\text { at completion of run. }\end{array}$ \\
\hline 16 & $\mathrm{MnO}_{2}$ & 0.58 & -- & -- & 104 & --- & --- & $\begin{array}{l}\text { No apparent effect; solution was opaque when the } \mathrm{MnO}_{2} \text { was first } \\
\text { added. Changed to clear normal color after sparging with } \mathrm{HCl} \\
\text { overnight. }\end{array}$ \\
\hline
\end{tabular}

* Salt from previous run with added uranium.

* Density determined with a mercury porosimeter includes closed pores and pores iess than jis ajiminter. 
other laboratory studies (27) impurities were found to increase the chloride content of the deposit, apparently through the formation of oxychlorides, such as MoOCl and FeOCl, which were included in the deposited $\mathrm{UO}_{2}$ and which could not be leached from the deposit with water.

Hot Cell Prototype Operations

The LiCl-KCl system was selected for the Salt Cycle demonstration, (28) and the remotely operable equipment shown in Figure 29 was tested in the pilot plant. A double lid made of Hastelloy $B$ with stainless steel fittings was used. Lavite gaskets separated the chlorine-rich salt chamber from the exhaust chamber into which air leaked through the upper part of the lid. The effectiveness of this system in maintaining a dry atmosphere is discussed in a separate report. (29) The salt in the 20 liter fused-quartz crucible was kept molten by induction heating of the Hastelloy B susceptor by a $3 \mathrm{kc}$ coil. AIl connectors were remotely operable. The susceptor was insulated with a 1/4-in.thick layer of potassium titanate held in place by asbestos cloth and surrounded by a I/2-in.-thick free-standing Magnefrax $(B)$ insulating shield. The induction coil was insulated with glass sleeving set in Doryl $(\mathrm{R}$, and the air gap between the coil and susceptor was about two inches. Nearly $6 \mathrm{~kW}$ were required to keep the crucible at operating temperature, with a division of $1.3 \mathrm{~kW}$ generated in the coil and removed by the cooling water, $2.1 \mathrm{~kW}$ transferred from the susceptor to the coil through the insulation and removed by the cooling water, and $2.4 \mathrm{~kW}$ transferred from the susceptor and the salt bath to the atmosphere.

Aside from remote mechanical operability tests and the demonstration of an ability to process $30-1 b$ batches of $\mathrm{U}_{3} \mathrm{O}_{8}$, the major purposes of the operations in the prototype equipment were to develop a suitable cathode material and to produce a standard product to be used in development of remotely operable crushing and sieving equipment. A summary of the prototype pilot plant runs is presented in Table XIV.

Flectrolysis operations were first conducted in $1: 1$ LiCl-KCl in which codeposition of $\mathrm{UO}_{2}$ and $\mathrm{PuO}_{2}$ was most likely to be carried out, and then in 2.5:I LiCl-KCl, in which precipitation of $\mathrm{PuO}_{2}$ might be conducted as part of
(R) Union Carbide Company
(B) The Carborundum Company
(B) Westinghouse Electric Co. 
TABSIE XIV

HOT CBLL PROTOOYYPE RLECTRBLYYSES

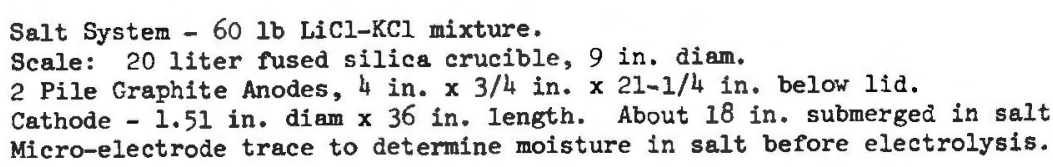

$$
\text { DIsSOLUTION }
$$

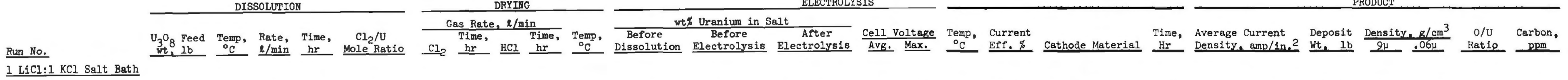

\begin{tabular}{|c|c|c|c|c|c|c|c|c|c|c|c|c|c|c|c|c|c|c|c|c|c|c|c|c|c|c|}
\hline \multicolumn{27}{|c|}{1 LiCl:1 KCI Salt Bath } \\
\hline HS-1 & 30 & 600 & $\sim 2.0$ & 72.0 & 7.9 & 1.2 & 23.0 & 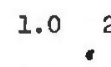 & 23.0 & 535 & none & 26.4 & 4.04 & 1.20 & 1.40 & 540 & 70.9 & Pile Graphite & 28.5 & 0.85 & 24.6 & 10.95 & 10.97 & 2.0129 & 115 & Sheared product from cathode with hydraulic jeck. \\
\hline HS-2* & 30 & 600 & 2.42 & 48.0 & 6.3 & 1.2 & 20.0 & $1.2=$ & 23.5 & 600 & 4.0 & 28.9 & 9.38 & $1.5 ?$ & 2.19 & 535 & $70.0 * *$ & Pile Graphite & 25.0 & 0.94 & 24.6 & 10.90 & 10.92 & 2.0023 & 25 & $\begin{array}{l}\text { c12 sparge time is approximate as a cylinder ran } \\
\text { empty during the night. }\end{array}$ \\
\hline HS-3" & 55 & 600 & 2.4 & 53.5 & 3.9 & 1.2 & & 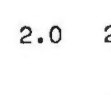 & 20.0 & $\begin{array}{l}\text { tso } \\
\text { to } \\
600\end{array}$ & 9.4 & 39.0 & 24.9 & 1.85 & 2.20 & 535 & $58.1 * *$ & Pile Graphite & - & 1.58 & 32.4 & 10.86 & 10.94 & 2.0018 & 20 & $\begin{array}{l}\text { Cathode was grounded durng part of electrolysis. } \\
\text { This caused a flat spot on the deposit. }\end{array}$ \\
\hline нS- $-4 *$ & none added & 600 & 1.2 & 3.5 & --- & 1.2 & & 2.12 & 48.0 & 535 & 24.9 & 24.9 & 1.4 & 2.0 & 2.27 & 535 & 73.8 & Pile Graphite & 19.9 & 1.06 & 21.5 & 10.88 & 10.92 & 2.0040 & 60 & 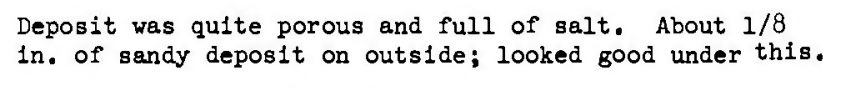 \\
\hline \multicolumn{27}{|c|}{2.5 Licl: 1 KC1 Salt Bath } \\
\hline нз-5 & 30 & 600 & 3.7 & 55.0 & 11.2 & 0.64 & & 1.012 & 120.0 & 535 & none & 26.3 & 7.8 & 1.43 & 1.75 & 562 & 69.1\%* & Pile Graphite & 24.1 & 1.09 & 20.0 & $10.87 \mathrm{~T}$ & 10.91 & 2.0081 & 15 & Hai to increase temperature to electrolyze vith this salt. \\
\hline HS-6* & 30 & 620 & 3.0 & 57.0 & 9.4 & 1.8 & & 1.0 & 5.0 & 575 & 7.8 & 25.7 & 16.3 & 1.35 & 1.51 & 565 & 67.4 & $\begin{array}{l}\text { Pyrolytic } \\
\text { Graphite Coating }\end{array}$ & 24.6 & 1.18 & 21.5 & 10.84 & 10.89 & 2.0124 & 23 & 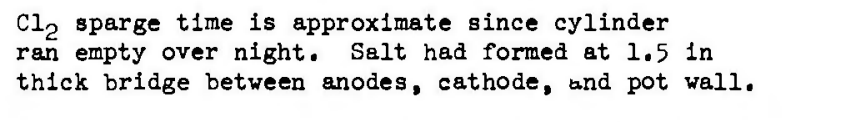 \\
\hline нв-7** & 20 & 620 & 2.0 & 26.0 & 4.6 & 1.0 & & 1.02 & 20.0 & 570 & 10.1 & 29.3 & 10.1 & 1.52 & 1.86 & 570 & 75.6 & $\begin{array}{l}\text { Pyrolytic } \\
\text { Graphite coating }\end{array}$ & 21.0 & 1.57 & 24.3 & 10.67 & 10.88 & 2.0068 & 25 & $\begin{array}{l}\text { Deposst broke avay from cathode with no visual loss } \\
\text { of carbon. }\end{array}$ \\
\hline 3-8* & 25 & 700 & 3.0 & 24.0 & 4.8 & --- & -- & $1.0=$ & 26.0 & 565 & 14.6 & 31.3 & 14.9 & 1.40 & 1.48 & 565 & 62.5 & $\begin{array}{l}\text { yrolytic } \\
\text { Graphite coat Ing }\end{array}$ & 24.6 & 1.32 & 19.2 & 10.83 & 10.91 & 2.0015 & 22 & \\
\hline s-9 & 31 & 600 & 2.3 & 27.0 & 3.3 & 1.0 & & $1.0=$ & 22.5 & 600 & none & 26.0 & 13.0 & 0.90 & 1.20 & 555 & 52.2 & $\begin{array}{l}\text { PYyolyytic } \\
\text { Graphite Coating }\end{array}$ & 35.5 & 1.18 & 17.4 & 10.86 & 10.89 & 2.0308 & 7 & $\begin{array}{l}\text { Dissolution study using } 9 \text { 1n. Iong gas lift with } \\
c_{2} \text {. }\end{array}$ \\
\hline
\end{tabular}

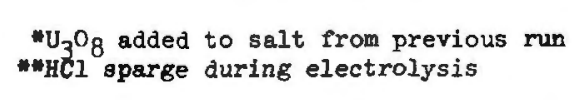




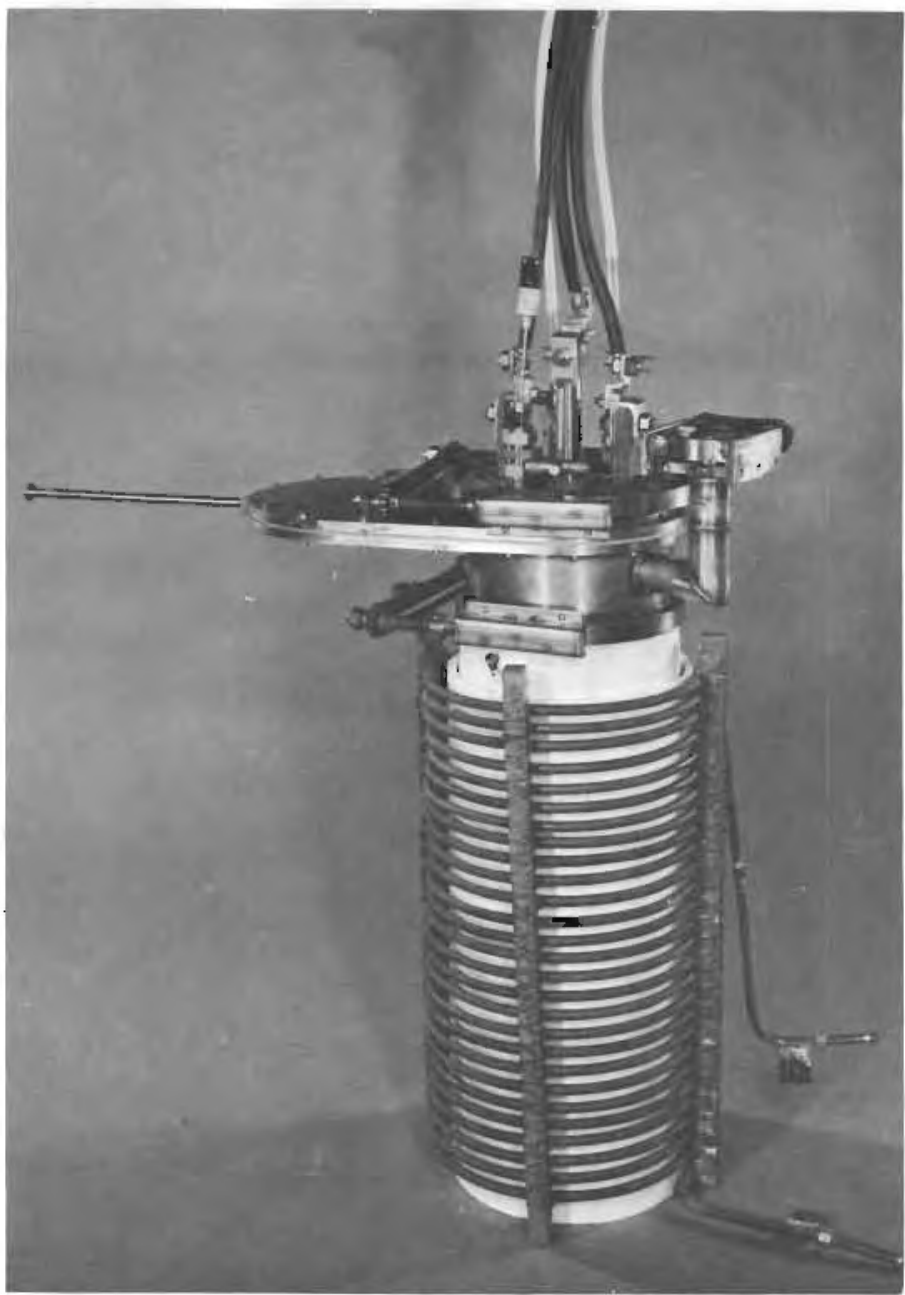

Twenty Liter Salt Bath

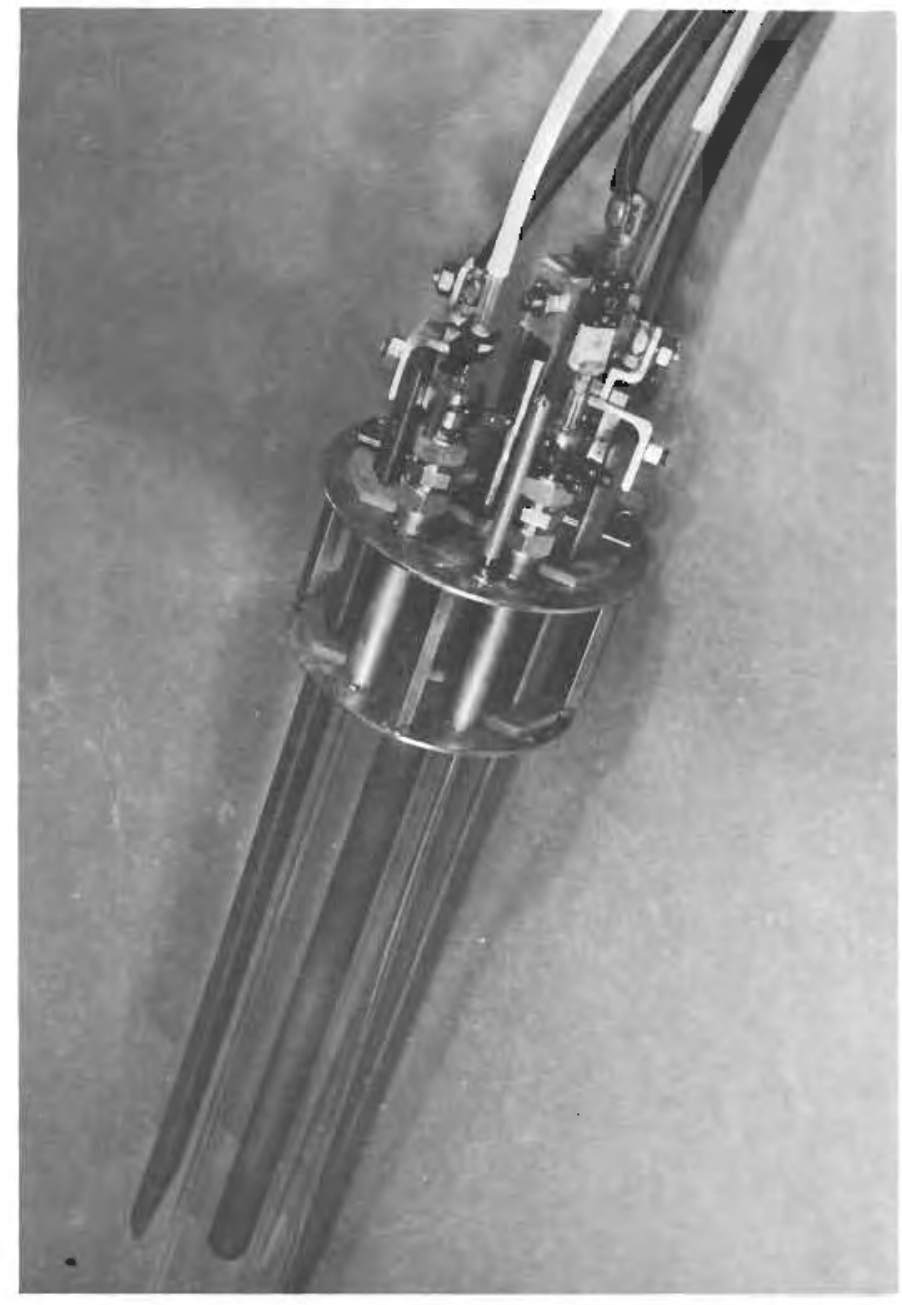

Electrolysis Lid 
the integrated operations. Essentially no difference in $\mathrm{U}_{3} \mathrm{O}_{8}$ dissolution or $\mathrm{UO}_{2}$ electrodeposition was found between the two salt bath compositions, except that an increased operating temperature was required to keep $\mathrm{KCl}$ from freezing out of the $2.5: 1$ salt bath.

The dissolutions in Figure 30 show that with single $8 \mathrm{~mm}$ quartz sparge tubes an increase in dissolving rate was obtained by increasing the temperature from $600{ }^{\circ} \mathrm{C}$ to $700^{\circ} \mathrm{C}$ and increasing the chlorine rate from 2 to 3 liters/ min. Comparison of the suspended, undissolved $\mathrm{U}_{3} \mathrm{O}_{8}$ in Figure 31 with Figure 30 shows that a submerged annular gas lift is quite effective in fluidizing $\mathrm{U}_{3} \mathrm{O}^{\circ}$. The solids were not uniformly distributed throughout the bath so that the weight percent solids at the sample point about 6 inches above the bottom of the crucible can only be interpreted qualitatively. In spite of the better fluidization, the dissolution rate was slower in Figure 31 because the dissolution of $\mathrm{U}_{3} \mathrm{O}_{8}$ is speeded up by the presence of dissolved $\mathrm{UO}_{2} \mathrm{Cl}_{2}$. Thus, a characteristically increasing rate of dissolution with time is obtained until the amount of undissolved $\mathrm{U}_{3} \mathrm{O}_{8}$ decreases sufficiently to again reduce the rate。

The higher than stoichiometric concentrations of uranium in the salt in the early stages of dissolution are not due to suspended solids but to the solubility of $\mathrm{U}_{3} \mathrm{O}_{8}$ and the formation of lower chlorides such as $\mathrm{UO}_{2} \mathrm{Cl}_{2}$. Such behavior has also been noted in $\mathrm{PbCl}_{2}-\mathrm{KCl}$ pilot plant operation. The solubility of $\mathrm{U}_{3} \mathrm{O}_{8}$ has been found to be greater in systems with high concentrations of dis solved $\mathrm{UO}_{2} \mathrm{Cl}_{2}$ (30) This may be the explanation for the increased rates of dissolution found in nearly all pilot plant runs in which dissolved $\mathrm{NO}_{2} \mathrm{Cl}_{2}$ remains from previous runs made in the same bath.

The dryness testing apparatus was used in all runs to determine whether the bath was ready for electrolysis. Since this apparatus was too cumbersome to be used in hot cell operations, the dissolution and drying times developed in the prototype runs were used as guides to hot cell operation.

Although the reference potential system was built for hot cell runs, it was to be installed in the same lid port from which the samples were to be taken because of space limitations. Since removal of the reference electrode each time a sample was taken proved to be unworkable, the total cell voltage was used to control the electrolysis in the prototype runs. Figure 32 shows the relationship between the reference potential and the total cell voltage. 


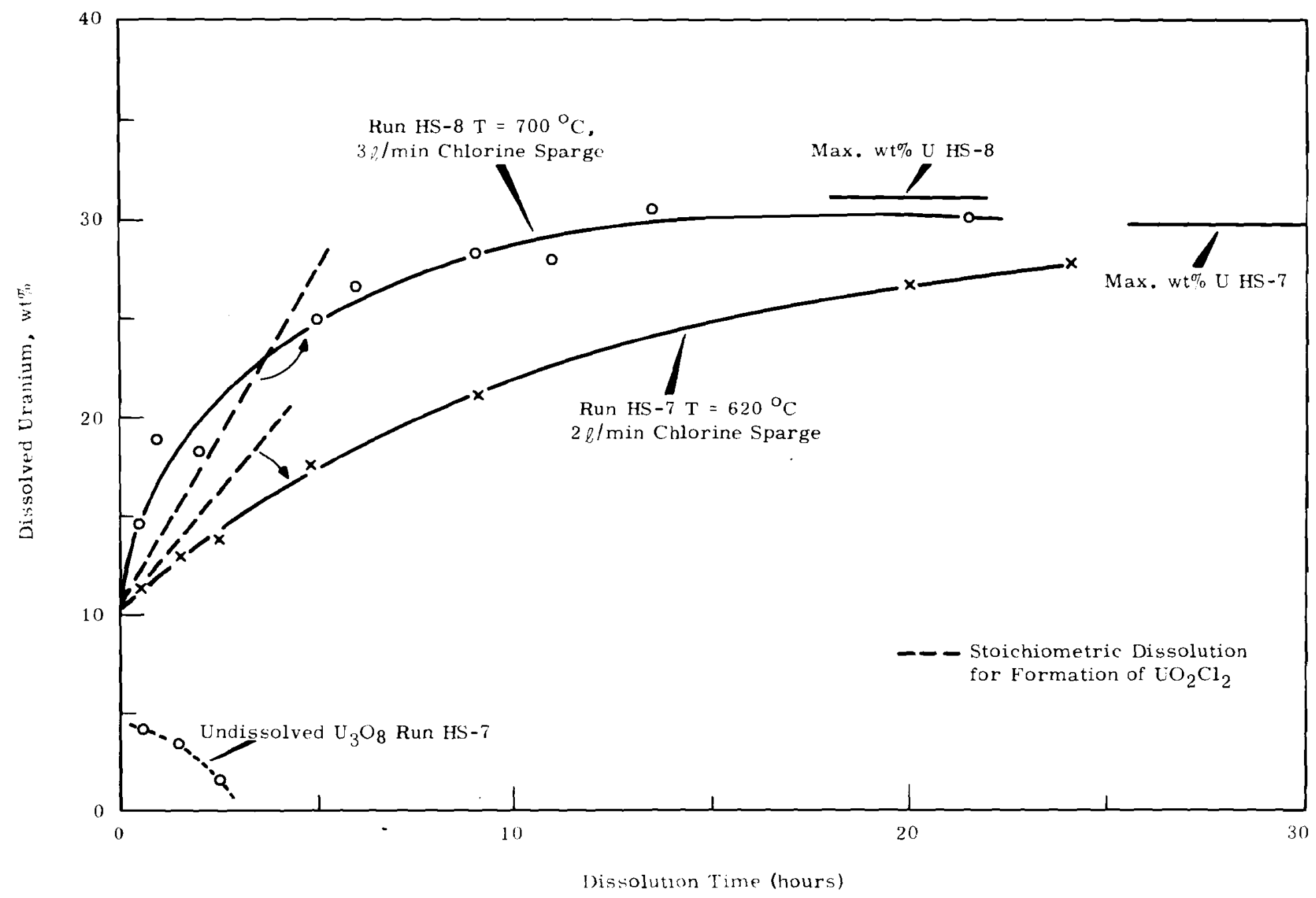

FIGURE 30

Dissolution of $\mathrm{U}_{3} \mathrm{O}_{8}$ in $2.5 \mathrm{LiCl}-1 \mathrm{KCl}$ 


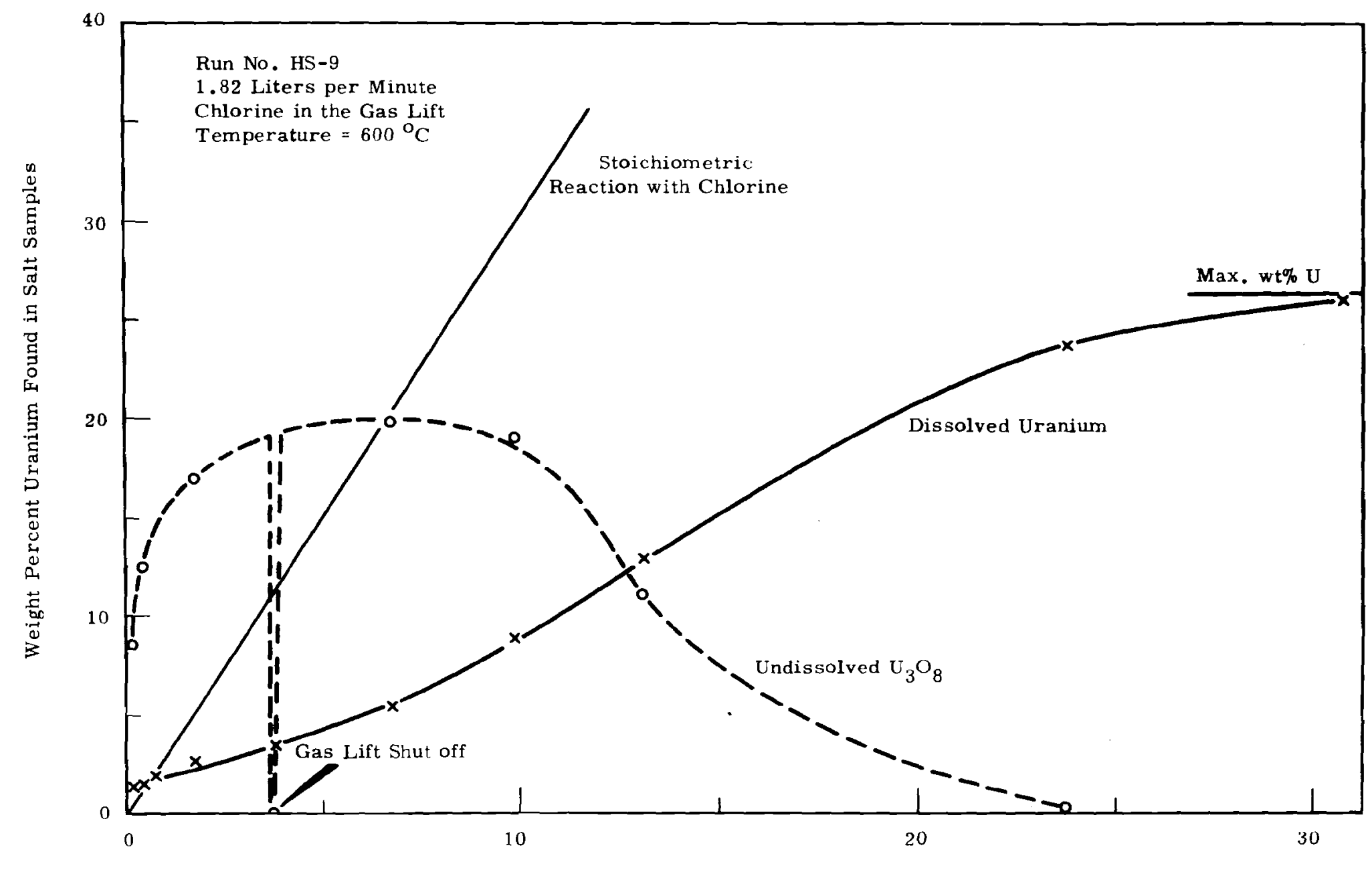

Dissolution Time (hours)

FIGURE 31

Dissolution of $\mathrm{U}_{3} \mathrm{O}_{8}$ in $2.5 \mathrm{LiCl}-1 \mathrm{KCl}$ with a Gas Lift 


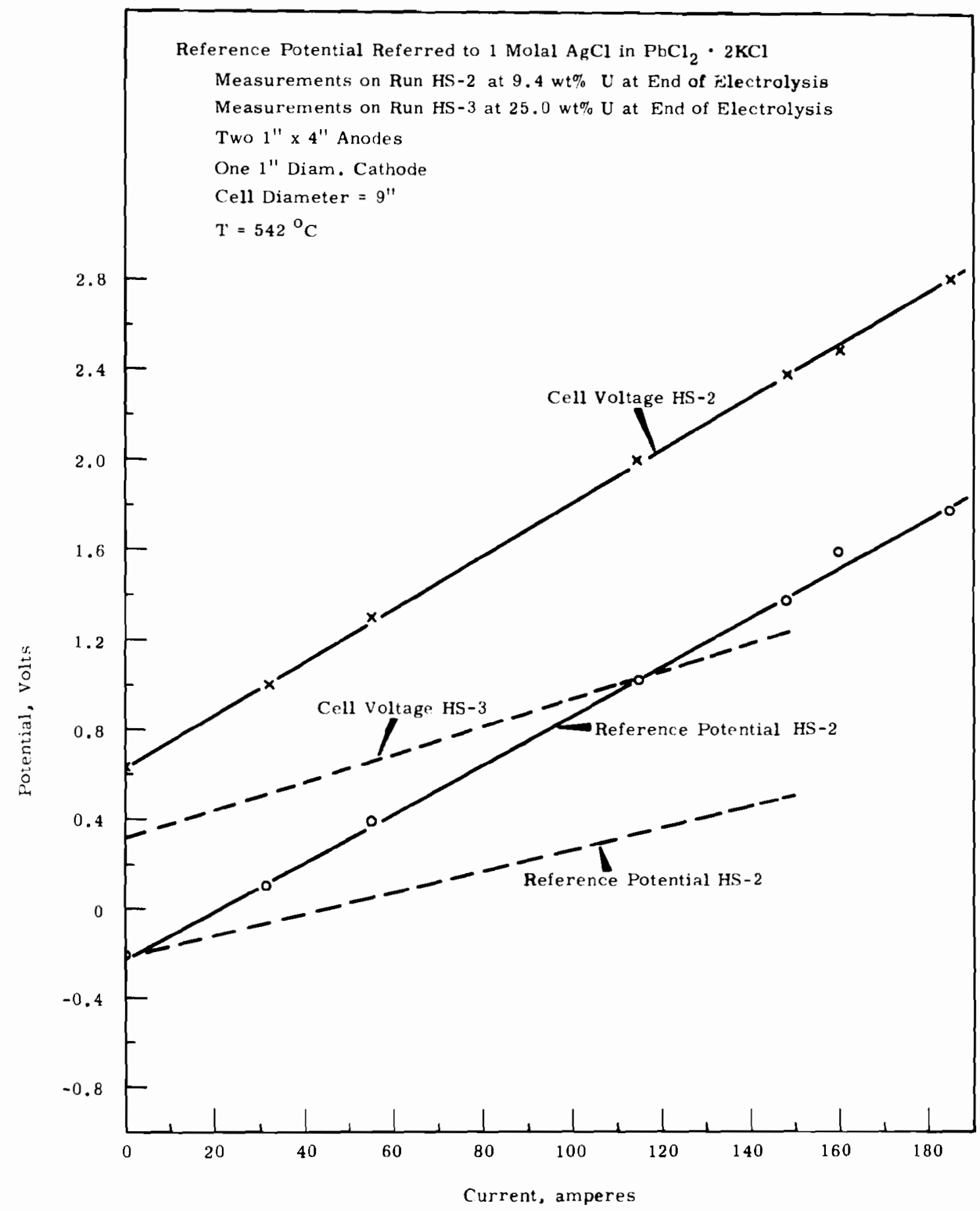

FIGURE 32

Voltage-Current Relationships in the Hot Cell Prototype Equipment 
With no current flowing, the reference potential is nearly independent of the wt $\%$ ranium in the bath, while the total cell voltage is higher for 9.4 wt $\mathrm{U}$ than for $25.0 \mathrm{wt} \% \mathrm{U}$. The difference in total cell voltages is apparently due to a difference in the reactions at the anodes at the two concentrations. Both the reference potential and the cell voltage increase linearly as the current is increased indicating that the resistance of the cell is nearly constant, but the $25 \mathrm{wt} \% \mathrm{U}$ system has a lower resistance than the $10 \mathrm{wt} \% \mathrm{U}$ system. Although the possible importance of the contact resistance of the leads to the cathode cannot be ruled out, the major difference between the two systems is the existence of a polarized layer around the cathode at the lower concentration. The 25 wt $\%$ u system had a $1 / 3$ larger deposit of $\mathrm{UO}_{2}$ on the cathode during the test, which indicates that the $\mathrm{UO}_{2}$ deposit resistance is not the most important part of the resistance of the cell. The thicker $\mathrm{UO}_{2}$ deposit could actually lower the resistance of the cell in this case by increasing the total surface area of the cathode and reducing the current density at the surface. In practice, within the region of constant cell resistance, the cell voltage and reference potential as a function of concentration can be estimated at zero current for a given apparatus; and a constant difference due to cell resistance can be subtracted from the cell voltage to estimate the reference potential at any operating current.

The crystal characteristics of the product of the hot cell prototype electrolyses, shown in Figure 33, were remarkably constant although the uranium concentration varied from $39 \mathrm{wt} \%$ to $1.4 \mathrm{wt} \%$ in the series. Only at the lowest concentration was a porous, sandy structure noted. A typical deposit on a 1.5-in. diam graphite cathode is shown in Figure 34. Deposit weights varied from 17 to $32 \mathrm{lb}$. The reproducibility of the runs is attributed to (1) the long drying times which removed the last traces of moisture and undissolved solids, (2) the lack of impurities in the bath because of pure feed and the use of graphite electrodes, and (3) the narrow range of current densities that resulted in the same small degree of redissolution of the $\mathrm{UO}_{2}$ while it was depositing.

The product of the first five electrolyses was of little use for crushing studies since it could not be separated from the pile-graphite electrodes. 


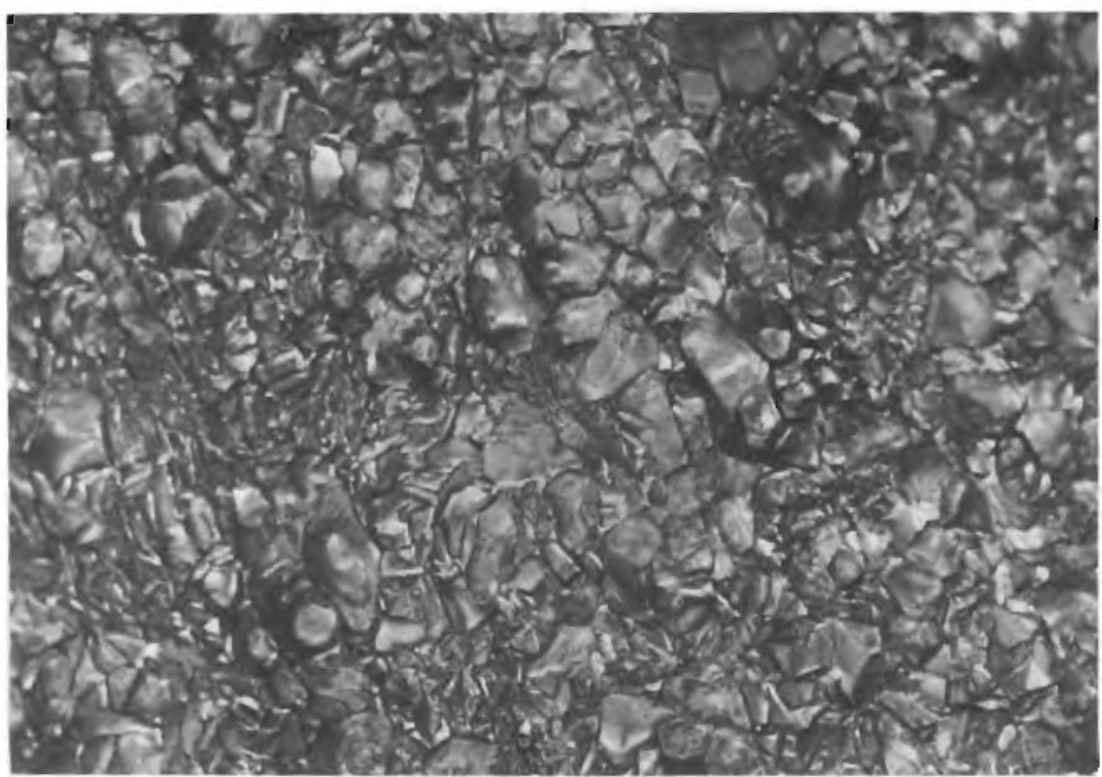

Growing Surface

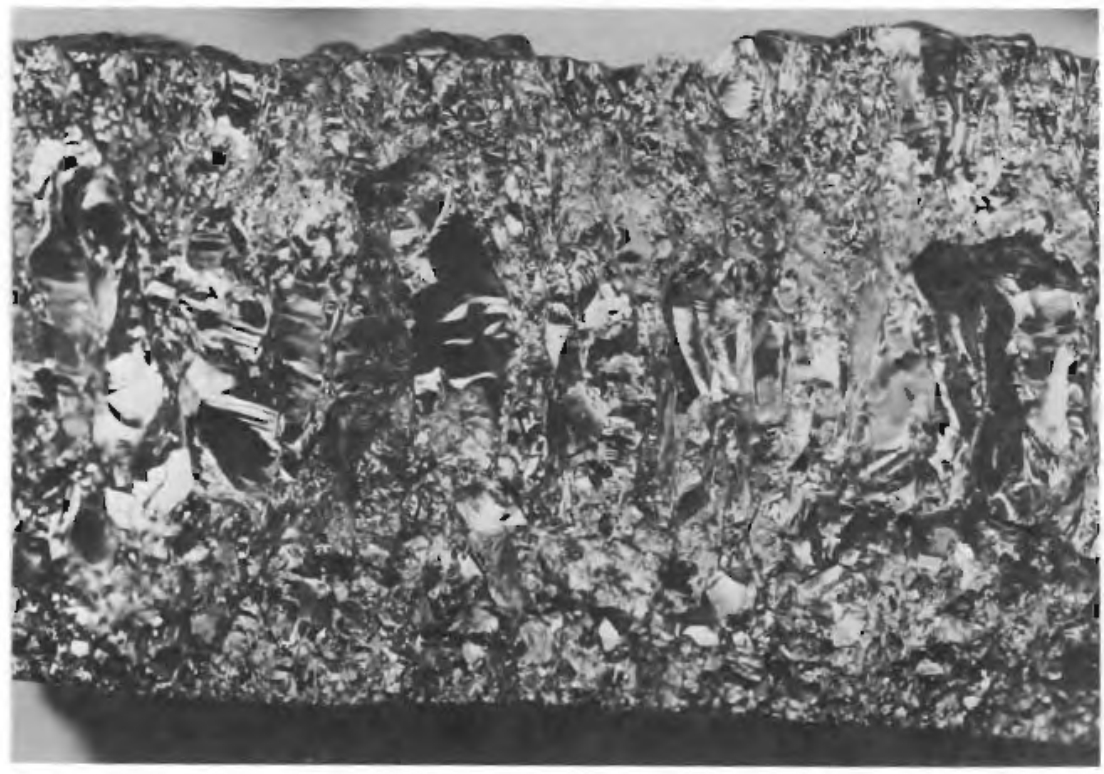

Cross Section

$$
\mid+10^{14}
$$

FIGURE 33

Crystal Characteristics of Hot Cell Prototype Electrolysis Product, Run HS -5 O $/ U$ Ratio $=2.008$ 


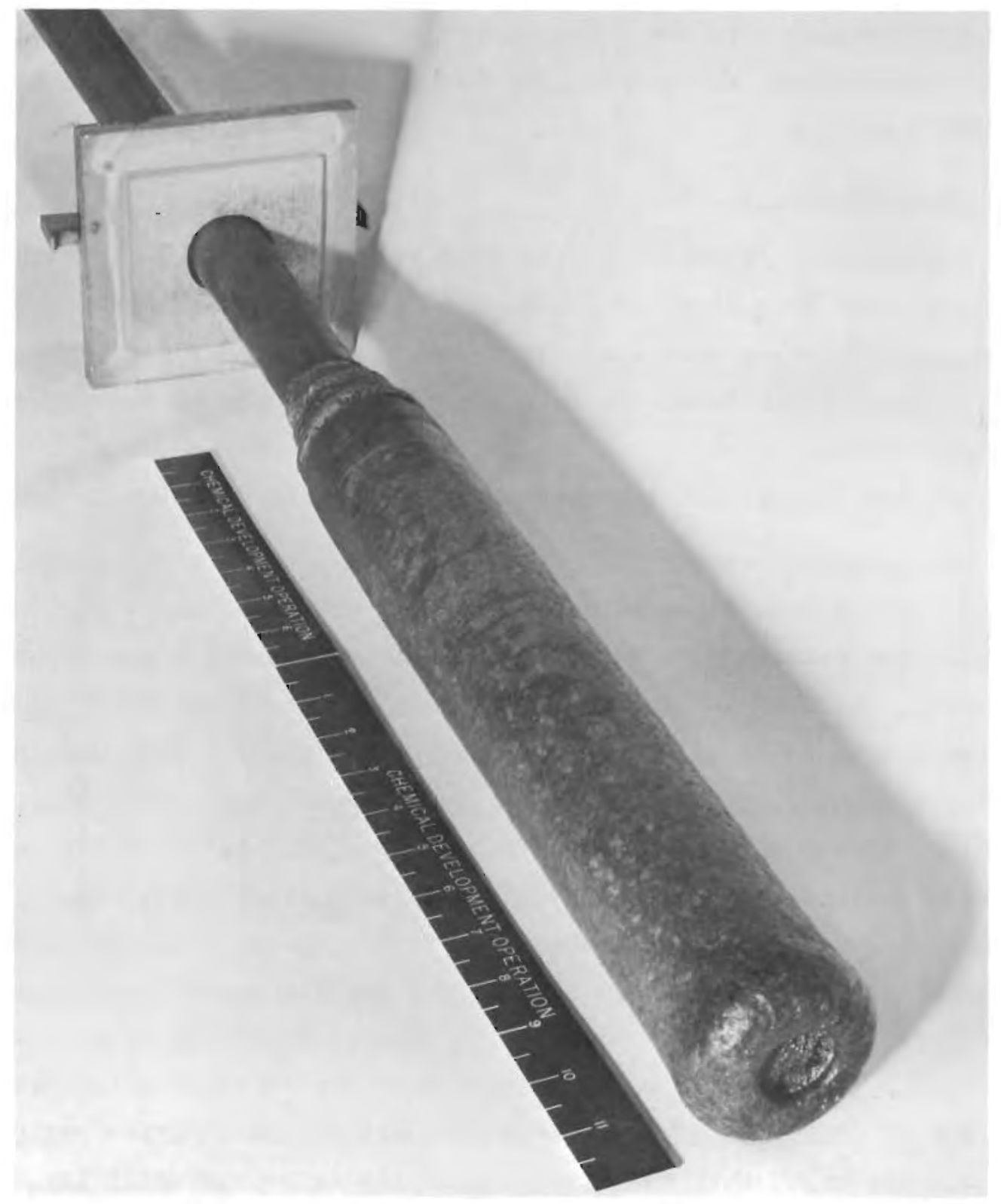

1.5 in. Diam. Pyrolytic Graphite Cathode,

Run HS-9 Deposit Weight 17.4 1b.

FIGURE 34

Typical Deposit from the Hot Cell Prototype Electrolysis 
The introduction of pyrolytic graphite cathodes, discussed under cathode evaluation (page 103), allowed the material from later runs to be treated as a standard product for stripping, crushing and washing studies. The relatively low carbon contents in the $\mathrm{UO}_{2}$ produced on pile graphite are values in the bulk of the deposit and do not include the attached layer of carbon at the electrode surface.

\section{Product Purification}

A comparison of the composite products from the LiCl-KCl salt baths is shown in Table XV. After crushing, the fines contained higher percentages of oxygen and carbon than the bulk of the material that was in $-4+10$ mesh range. This is reasonable because the high $O / U$ material was deposited first as small crystals next to the electrode where the carbon content was highest. The chloride and lithium contents were only a weak function of particle size.

The product from Run HS-8 was removed from the electrode as large chunks, rinsed with water to remove surface chloride, and was crushed and sieved. The results of a washing.study on this material are presented in Table XVI. Each screen fraction of the oxide was washed with tap water for varying time periods in shallow beds on sieve plates. Although the tap water contained $2.75 \mathrm{ppm}$ chlorine, control experiments with distilled water showed no effect of this chlorine on the results. Both the lithium and chloride analyses, although somewhat scattered, showed that washing times up to $480 \mathrm{hr}$ on particle sizes ranging from 0.09-in. to 0.75-in. diam had no effect on the impurity level. The salt is apparently trapped within the $\mathrm{UO}_{2}$ and cannot be leached out with water. Since the deposit was formed in a $2.5 \mathrm{LiCl}-1 \mathrm{KCl}$ salt bath, which has a mole ratio of lithium-tochloride of 0.71 , one may speculate that either the chloride analysis is consistently high, that the lithium analysis is consistently low, or that chlorides of impurities such as FeOCl are preferentially present in the deposit. Spot checks of the $\mathrm{Li} / \mathrm{K}$ ratio indicate that $\mathrm{KCl}$ may enrich in the deposit over $\mathrm{LiCl}$ enough to account for the excess chloride, so that preferential adsorption of $\mathrm{KCl}$ on the deposit, or deposition and redissolution of small amounts of potassium metal at the cathode might explain the 


\section{TABLE XV}

\section{CHEMICAL ANALYSIS OF COMPOSITE PRODUCT}

\section{FROM LiCl-KCl PILOT PLANT OPERATIONS}

Composite of HS-1, 2, 3, 4, 9

(Pile Graphite Cathode)

Tyler Mesh Size

$$
-4+10
$$$$
-10+35
$$$$
-35+65
$$$$
-65
$$

\section{$\underline{0 / U \text { Ratio }}$}

2.007

2.024

2.028

2.043 ppm C

152

$-$

$--$

517 ppm Cl

28

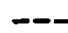

$--$

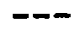

ppm Li

10

20

32

34

Composite of HS-5, 6, 7, 8

(Pyrolytic Graphite Cathode)

$\begin{array}{rrrrr}-4+10 & 2.009 & 23 & -- & 18 \\ -10+35 & 2.015 & -- & -\cdots & 18 \\ -35+65 & 2.027 & -\cdots & --- & 22 \\ -65 & 2.031 & 31 & 158 & 18\end{array}$

Composite of LK-26, 27, 28, 29, 30, 31, 32 (Pile Graphite and Hastelloy D Cathodes)

$\begin{array}{lrrrr}-4+10 & 2.007 & 528 & -\cdots & 14 \\ -10+35 & 2.005 & -- & 53 & 33 \\ -35+65 & 2.004 & -\cdots & 183 & 30 \\ -65 & 2.021 & 760 & -\cdots & 41\end{array}$


TABLE XVI

CHLORIDE ANALYSES IN AQUEOUS WASHING STUDIES

Feed Material: Screen Fractions of Run HS-8

Treatment: Washed with tap water containing $2.75 \mathrm{ppm}$ Cl continuously by flow through a shallow packed bed.

$-8+10$ Mesh Particles

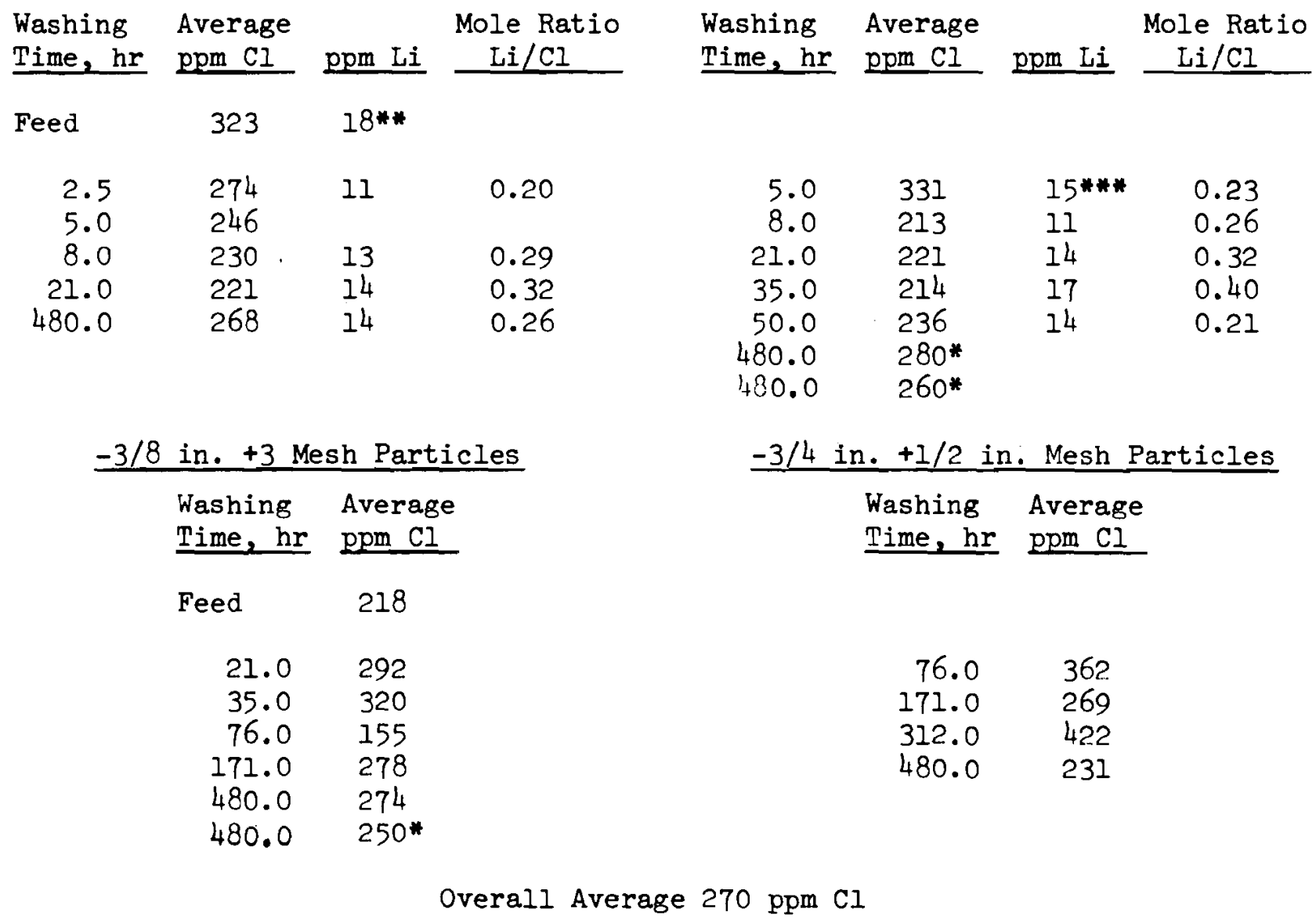

* Reanalysis approximately one year later.

$* \mathrm{~K}=80 \mathrm{ppm}, \mathrm{Li} / \mathrm{K}$ mole ratio $=1.25$ in deposit.

$* * *_{K}=90 \mathrm{ppm}, \mathrm{Li} / \mathrm{K}$ mole ratio $=0.93$ in deposit. 
results. Because particle size had no apparent effect on the washing efficiency in this study, the large $1 / 2$ to $3 / 4 \mathrm{in}$. diam chunks of oxide were washed for only a few hours in the Salt Cycle demonstration ${ }^{(7)}$. This proved to be an advantase in the operating of the equipment, since fines entrainment in the wash liquor is minimized and after the drying operation the large pieces of oxide can be poured readily without dust formation.

Hydrogen reduction of high $\mathrm{O} / \mathrm{U}$ ratio $\mathrm{UO}_{2}$ was readily accomplished in the oxidizer furnace with argon - 8 vol\% hydrogen at 600 to $700{ }^{\circ} \mathrm{C}$ for $24 \mathrm{hr}$. The results in Table XI (page 65) for lead chloride removal at $1000{ }^{\circ} \mathrm{C}$ indicate that high temperature hydrogen reduction might also be useful in removing chloride, although it is doubtful whether the chloride occluded within the $\mathrm{UN}_{2}$ would migrate even at $1000^{\circ} \mathrm{C}$.

\section{DIJECTRODE EVALUATEOA}

The choice of electrodes in the Salt Cycle system is limited by the corrosive environment and $\mathrm{by}$ the need to separate the $\mathrm{JO}_{2}$ deposit from the elactrode. At first, pile-graphite cathodes were used both as cathodes and anodes.

Graphite was replaced by Irastelloy $D$ as the cathode material in the $\mathrm{PbCl}_{2}-\mathrm{KCl}$ system because of carbon contamination of the product by mechanical interlocking, but excessive corrosion in the $\mathrm{LiCl-KCl}$ system caused a return to graphite. The eventual development of pyrolytic-graphite-coated electrodes solved the cathode material problem for the Salt Cycle demonstration. Anodes

At the $700{ }^{\circ} \mathrm{C}$ temperatures of the $\mathrm{NaCl}-\mathrm{KCl}$ system the corrosion of the graphite anodes by chlorine resulted in U(IV) production that severly limited the recovery of $\mathrm{UO}_{2}$ from the bath. At the $550^{\circ} \mathrm{C}$ temperature of the LiCl-KCl system this reaction was negligible in its effect on the $\mathrm{UO}_{2}$ deposition. However, traces of U(IV) present greatly influence plutonium behavior $(6,23)$ during codeposition.

In some runs the anodes were coated with MgO to prevent air oxidation in the vapor space. Although this retarded oxidation, the salt crept up under the $\lg \mathrm{O}$ and sloughed it off near the interface. 
Silicon carbide anodes and cathodes invariably developed a very high resistance immediately after being inserted in the bath. This may be related to the formation of an $\mathrm{SiO}_{2}$ coating.

\section{Metallic Cathodes}

Platinum made an excellent material for cathodes except that it suffered accelerated interfacial corrosion. The 20mil-thick platinum sheath on a nickel cathode used in an electrolysis in the $\mathrm{NaCl}-\mathrm{KCl}$ system at $700{ }^{\circ} \mathrm{C}$ corroded through at the salt-vapor interface in less than $30 \mathrm{~min}$. Examination of the knife-like cut showed that chlorine gas had apparently reacted with the platinum and redeposited it in the vapor space next to the corroded area. Similar but not so severe corrosion occurred in the LiCl-KCl system. The platinum cathodes were never attacked below the salt level in either system.

To overcome this difficulty, tests were made with a 3/4-in.-diam, 12-in.-long platinum-sheathed electrode protected with quartz at the melt interface, shown in Figure 35. It was necessary to flare the quartz sheath to keep

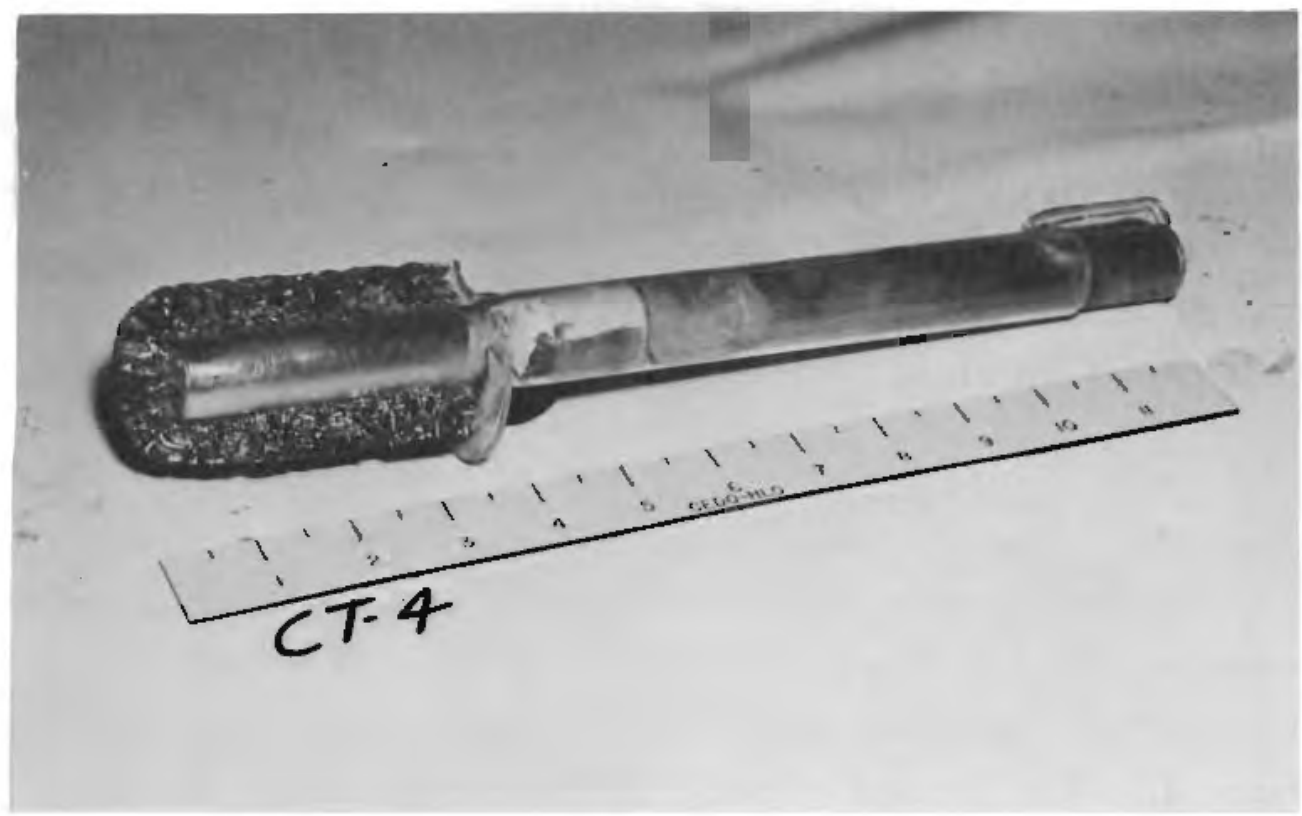

FIGURE 35

Platinum Electrode Sheathed with Quartz, Run CT-4 
the $\mathrm{UO}_{2}$ from growing over it. Even then the $\mathrm{UO}_{2}$ stuck to the quartz, so a pyrolytic graphite parting coat was put on the bottom of the quartz flare. The electrode still proved unsuitable because the salt crept up 2 or 3 in. by capiliary action between the close fitting quartz sheath and the platinum.

Of the other metallic cathodes only Hastelloy D and Duranickel showed any promise. Although Hastelloy $D$ is difficult to fabricate because of its $10 \mathrm{wt} \%$ silicon, it was used in several pilot plant runs in the $\mathrm{PbCl}_{2}-\mathrm{KCl}$ system because in corrosion tests it showed no accelerated interfacial attack. Corrosion of Hastelloy D in LiCl-KCl proved to be too great even for short-term experiments. Duranickel was tested in one pilot pant run in the $\mathrm{PbCl}_{2}-\mathrm{KCl}$ system with an interface protected with graphite. High corrosion rates resulted. Corrosion of the cathode always adversely affected the crystal structure of the deposited $\mathrm{UO}_{2}$. As typical example of this problem, Figure 36 shows a nickel cathode used in $\mathrm{LiCl}-\mathrm{KCl}$. The crystal size is greatly reduced by corrosion beneath the deposit.

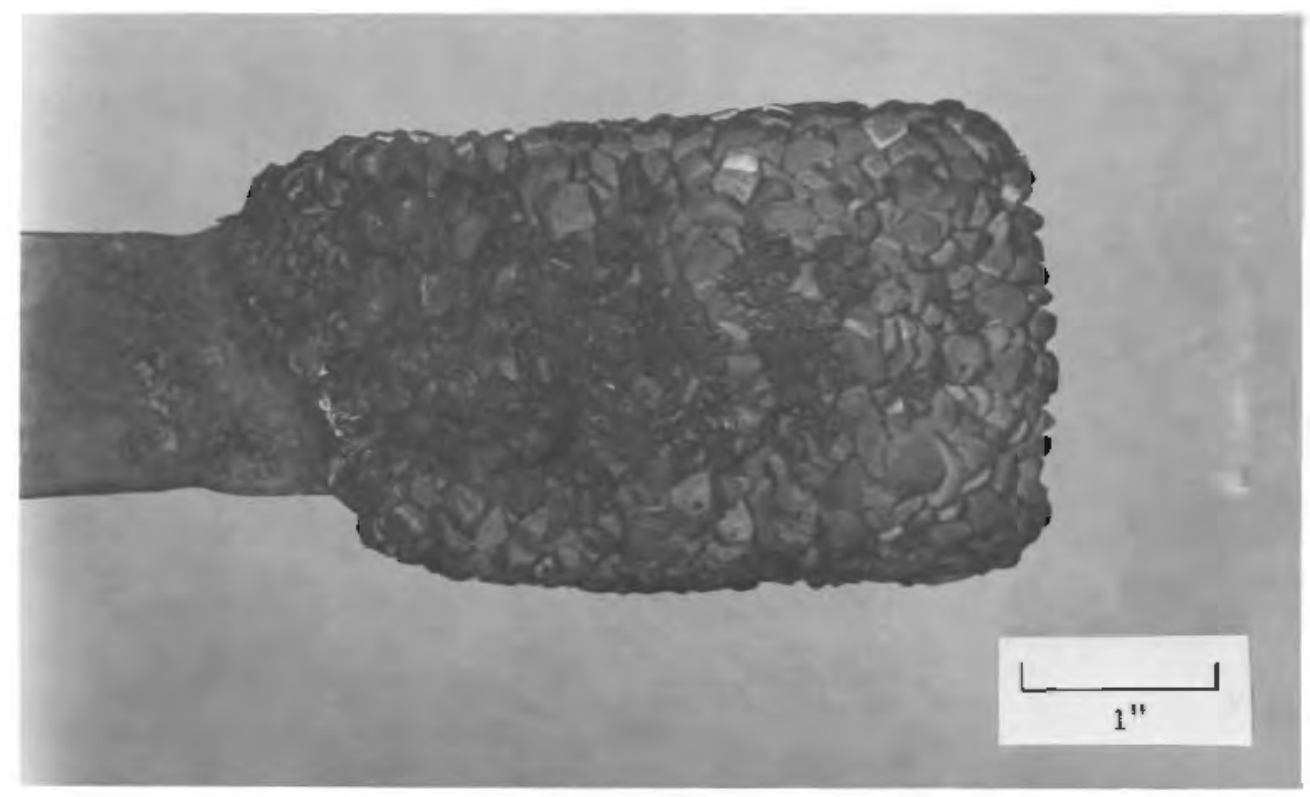

FIGURE 36

Effect of Corrosion of Nickel Electrode on $\mathrm{UO}_{2}$ Deposit 


\section{Graphite Cathodes}

Although reactor-grade graphite had adequate chemical resistance for use as cathodes, the porosity of the surface caused mechanical interlocking that resulted in gross carbon contanfnation of the $\mathrm{UO}_{2}$. Although this contamination was highly variable as can be seen from Tables VIII, IX, X, XII, and XV (pages 42, 55, 63, 67, and 89, respectively), the carbon content was often at least 500 ppm.

Hammers and wedges were used to chip the deposits off the flat cathodes in early pilot plant runs, but the round cathodes employed in the hot cell could not be handled in this way. In one attempt at removal, a die that was slightly larger than the 1.5-in.-diam electrode was forced along the electrode. Because the $\mathrm{UO}_{2}$ is both stronger and harder than the graphite, appreciable carbon was scraped off by the die. Centering problems were aggravated any time the die began to cut the soft carbon on one side of the electrode. Nevertheless, as shown in Table XIV (page 80 ), the bulk $\mathrm{NO}_{2}$ in the prototype runs had carbon contents as low as $100 \mathrm{ppm}$.

For remote operations a wedge mounted in a hydraulic press, shown in Figure 37, was used to split the $\mathrm{UO}_{2}$ deposit from the cathode. A thin

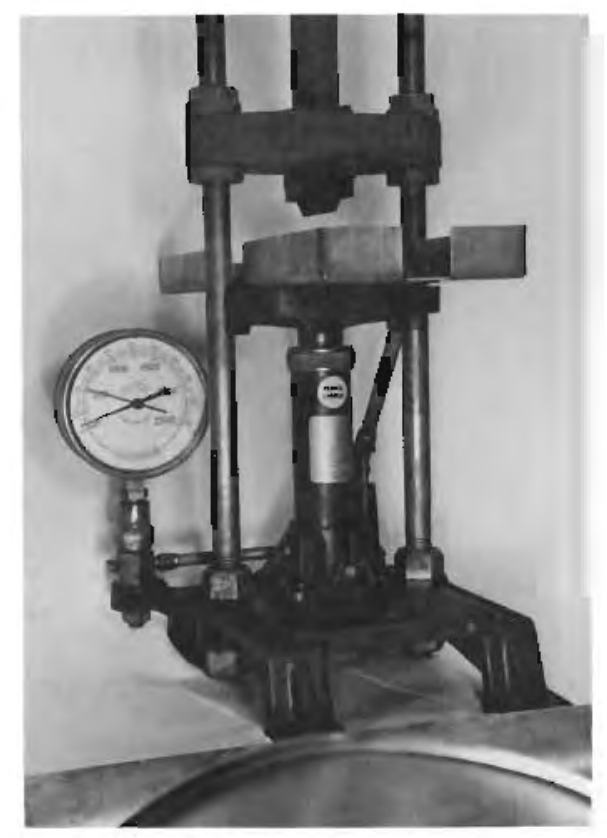

FIGURE 37

Electrode Stripping Apparatus 
pyrolytic graphite coating was applied to the pile graphite.* As shown in the plane-polarized light photograph in Figure 38, a pyrolytic graphite coating of only 0.25 mil thickness was sufficient to seal the pores of the surface of the electrode. The application of this coating produced immediate success in
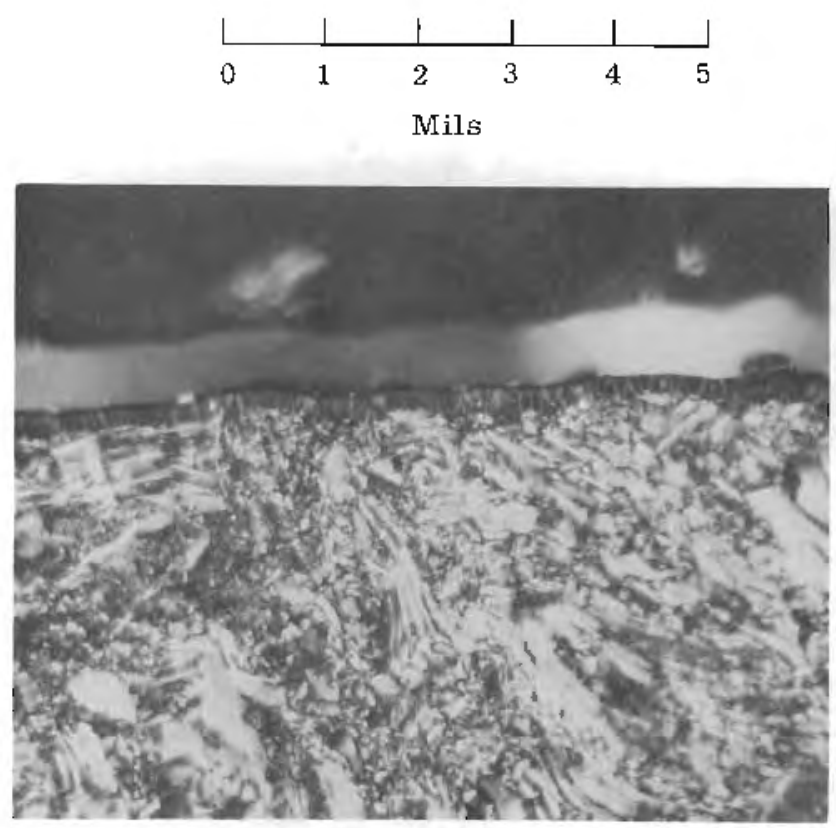

Plane-Polarized Light

FIGURE 38

Pyrolytic Graphite Coating on a Pile Graphite Cathode

separating the $\mathrm{UO}_{2}$ from the cathode (Figure 39). The wedge split the untreated cathode with essentially no separation of $\mathrm{UO}_{2}$ from carbon, while the $\mathrm{UO}_{2}$ split off the pyrolytic graphite cathode cleanly without affecting the coating. Analysis of the product shown in Table XII (page 67) gave carbon contents consistently below $50 \mathrm{ppm}$. The carbon content of the 1/16-inch-thick layer of $\mathrm{UO}_{2}$ nearest the cathode was about $50 \mathrm{ppm}$ with lower values in the bulk $\mathrm{UO}_{2}{ }^{*}$ Tests showed that the pyrolytic graphite cathodes could be used again many times. Pyrolytic graphite cathodes were used exclusively in the Salt Cycle demonstration and proved to be remotely separable from the deposits in all runs.

There is appreciable incentive to use pyrolytic graphite for anodes also, since laboratory studies have show it has less tendency to corrode and to react with the chlorine to form U(IV). (6) Whether this is due to decreased

* Pyrolytic graphite coating was performed by the Metallurgical Products Dept. of the General Electric Company, Detroit, Michigan and by High Temperature Materials, Inc., Boston, Massachusetts. 


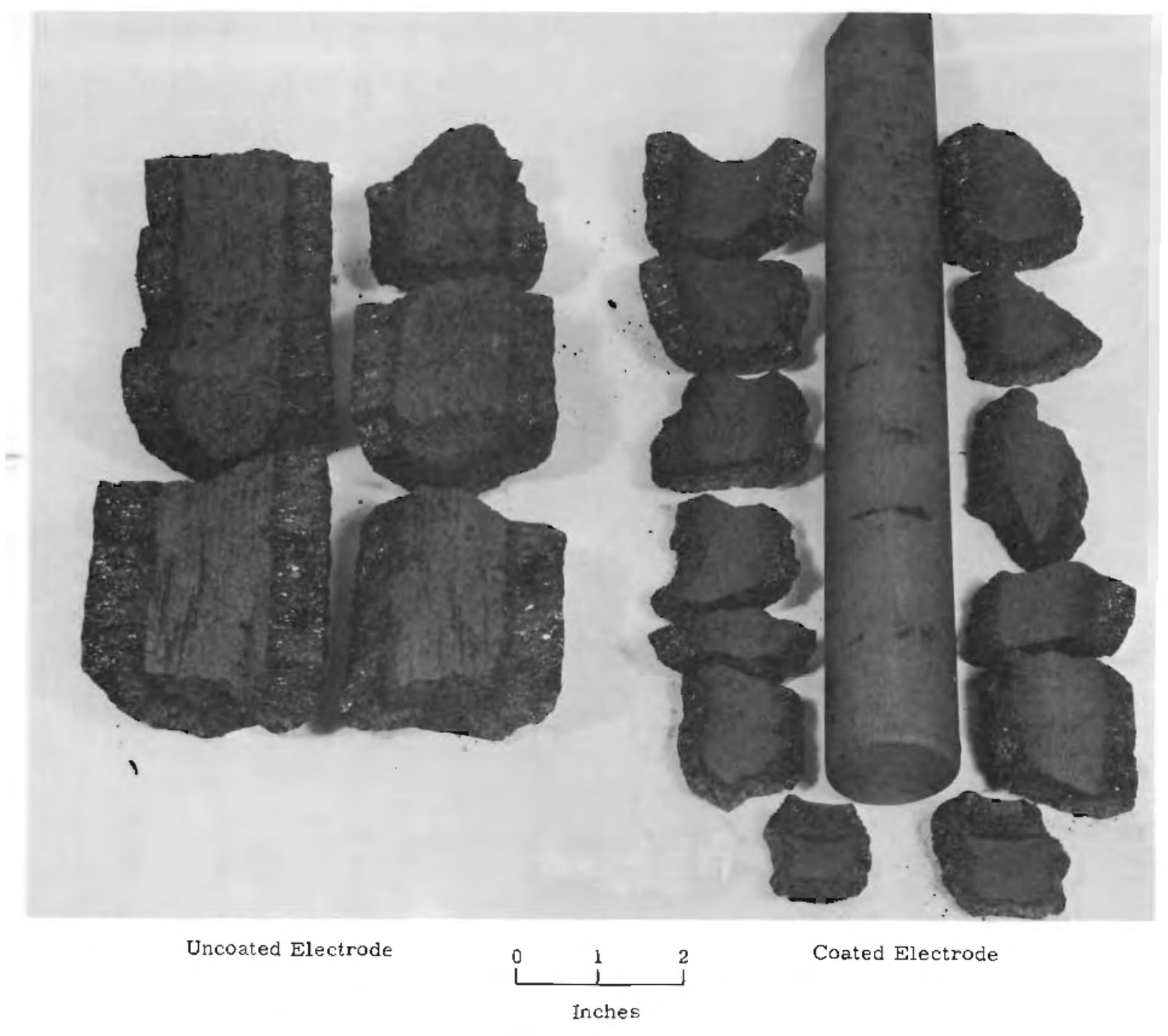

FIGURE 39

Comparison of Stripping of $\mathrm{UO}_{2}$ from Pyrolytic-Graphite-Coated Electrode with Stripping of a Pile Graphite Electrode 
electrode surface area, increased mechanical stability of the surface under slight corrosion, or chemical inactivity is not yet known.

\section{CONTAINER EVALUATION}

The Salt Cycle environment is a particularly harsh one for metallic materials of construction. The presence of wet chlorine and hydrogen chloride in the off-gas from the salt bath precludes the use of stainless steel, even at room temperature. Fortunately, as is shown in Figure 40, the temperatures in the pilot plant equipment used in the Salt Cycle demonstration ${ }^{(7)}$ were low enough so that nickel. Hastelloy $B$ and Hastelloy $C$ could be used in contact with the gas in the dual lid and in the off-gas lines. The susceptor in contact with chlorine gas at temperatures above $600^{\circ} \mathrm{C}$ was made of Hastelloy $\mathrm{B}$ and held up for several months if no salt contacted it.

\section{Metallic Crucible Materials}

The search for metallic crucibles began during the pilot plant operations in the $\mathrm{NaCl}$ system and was continued throughout operations in the other salt systems。An evaluation of metallic materials in the $\mathrm{NaCl}-\mathrm{KCl}$ system by Battelle-Columbus ${ }^{(31)}$ showed corrosion rates to be excessive, but pointed toward nickel-aluminum alloys as the best potential material. Further work was done in the other salt systems by W. L. Walker $(32)$ at Hanford Laboratories. The corrosion rates on a few of the materials used in Walker's studies are shown in Table XVII. Attack on metals at the gas-liquid interface was usually accelerated. Corrosion in the $\mathrm{LiCl}-\mathrm{KCl}$ system at $600^{\circ} \mathrm{C}$ was more rapid in some cases than in the $\mathrm{NaCl}-\mathrm{KCl}$ system at $800{ }^{\circ} \mathrm{C}$. The nickel-aluminum alloys, though brittle, showed great promise in LICl-KCl but the corrosion rates were increased by at least a factor of ten by adding $\mathrm{UO}_{2} \mathrm{Cl}_{2}$. Further work on varying compositions of these alloys with additives of other elements might prove fruitful, although the addition of chromium, for example, increased corrosion.

Fused Silica Crucibles

Fused silica vessels are satisfactory from a corrosion standpoint but are very brittle. Furthermore, in the pilot plant a frozen salt bath cannot be reheated without breaking the crucible. In the $\mathrm{NaCl}-\mathrm{KCl}$ system, the frozen salt 


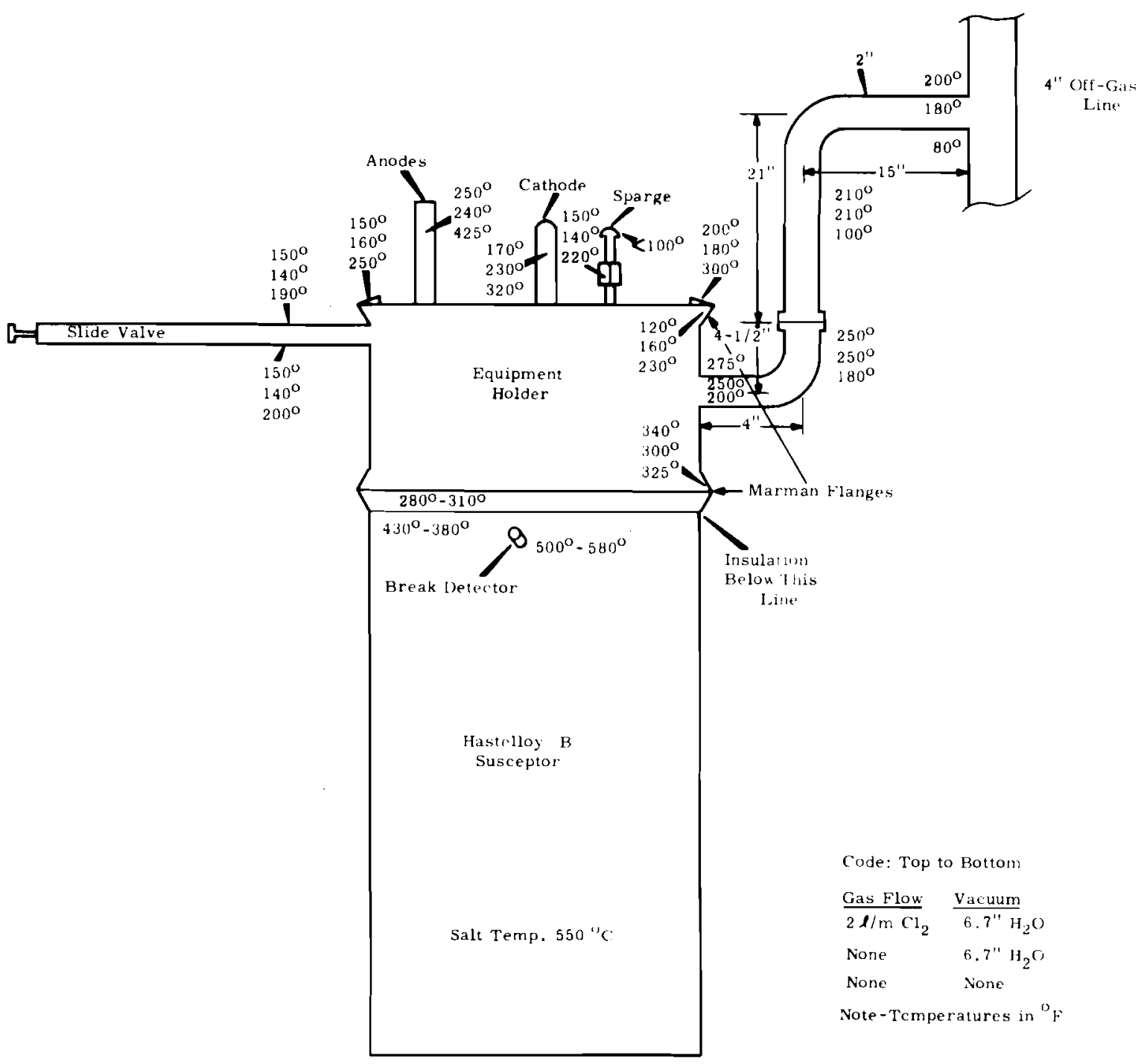

FIGURE 40

Temperature Profiles in the Salt Bath Mockup for the Salt Cycle Demonstration 


\section{TABLE XVII}

\section{CORROSION OF METALS IN THE SALT CYCLE ENVIRONMENT}

All exposures are single periods of about six hours, with a single sample exposed in a manner which resulted in approximately equal areas in the liquid and vapor phases. All systems were sparged at a rate of about $300 \mathrm{ml} / \mathrm{min}$.

Corrosion rates were calculated from weight losses, and represent an average rate over the entire sample. In most cases this average rate is considerably lower than the maximum rate at some point on the sample.

Systems
1. Equimolar $\mathrm{NaCl}-\mathrm{KCl}$
- 750 to $800^{\circ} \mathrm{C}$ - $\mathrm{HCl}$ sparge
2. $60 \mathrm{wt} \% \mathrm{PbCl}_{2}-40 \mathrm{wt} \% \mathrm{KCl}-600{ }^{\circ} \mathrm{C}$
3. $40 \mathrm{wt} \% \mathrm{LiCl}-60$ wt $\% \mathrm{KCl}-600{ }^{\circ} \mathrm{C}$
- $\mathrm{Cl}_{2}$ sparge
4. 40 wt\% LiCl-60 wt\% KCl
$-600{ }^{\circ} \mathrm{C}$
- HCl sparge
- $\mathrm{Cl}_{2}$ sparge

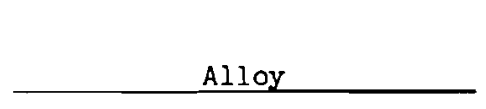

Hastelloy B

Hastelloy $C$

Hastelloy D

Inconel

Inconel $\mathrm{X}$

Inconel 70 ?

"A" Nickel

Permanickel

Duranickel

Tungsten

Hastelloy N (INOR-8)

Platinum

Molybdenum

Tantalum

Niobium

Titanium - $0.2 \mathrm{wt} \%$ Pd

Duriron

Durichlor

Special Alloys

BMI $15(\mathrm{Ni}-13 \mathrm{Al})$

BMI \#3 (Ni-15 Al)

BMI 16 (Ni-43 AI)

$\mathrm{Ni} A \mathrm{Al}(12.5 \mathrm{wt} \% \mathrm{Al})$

$\mathrm{NiAll}$

$\mathrm{N} 1-12.5$ at.\% $\mathrm{Al}-12.5$ at.\% $\mathrm{Cr}$

\begin{tabular}{l} 
System \\
\hline $1 \quad \frac{3}{3}-4$ \\
\hline
\end{tabular}

(All rates in mils per month)

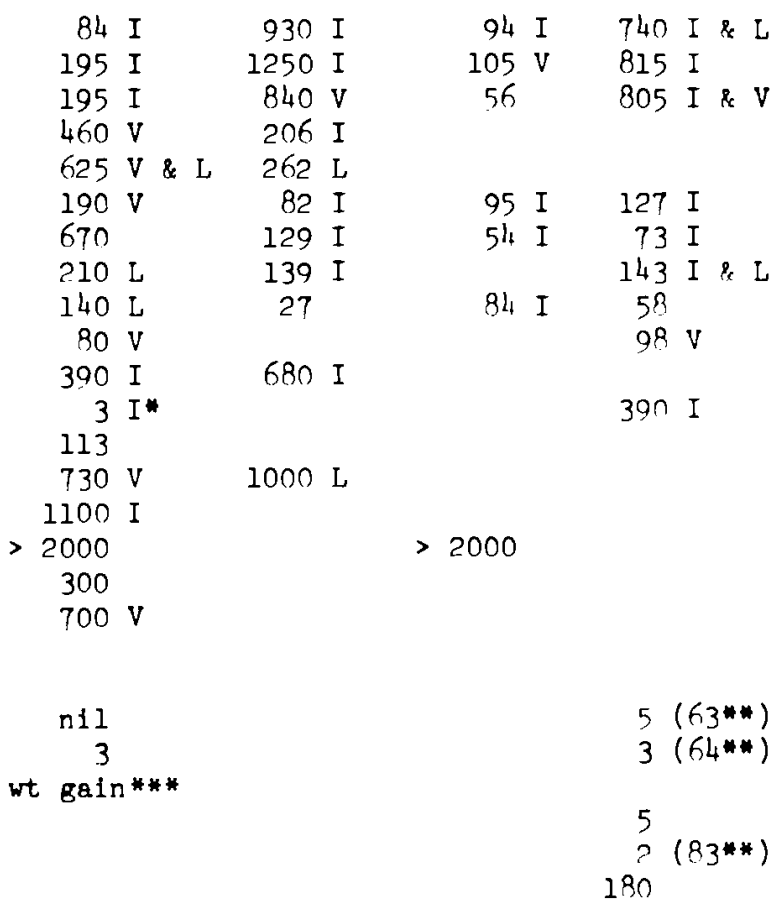

$V$ - Accelerated attack in vapor phase.

I - Accelerated attack at interface.

L - Accelerated attack in liquid phase.

Samples not designated with a letter exhibited relatively uniform corrosion.

"Sample exhibited an interface pitting rate of > $1000 \mathrm{mpm}$.

* Corrosion rate in presence of $10 \mathrm{wt} \% \mathrm{UO}_{2} \mathrm{Cl}_{2}$.

**:Sample is porous and salt penetrated completely through $1 / 4 \mathrm{in}$. thickness. 
shrank enough so that it could be removed from the crucible in one piece and the crucible could be reused. Reheating with salt in place always broke the crucible. In the $\mathrm{PbCl}_{2}-\mathrm{KCl}$ and $\mathrm{LiCl}-\mathrm{KCl}$ systems the salt could not be removed after freezing and the only way the crucible could be saved was by vacuum transfer of the salt into another container. The most critical point in the life of a crucible is at startup when fresh salt is being added and melted down until the vessel is full. Indefinitely-long crucible lifetimes are possible with steady-state operation at molten salt temperatures.

The durability of the quartz vessels when properly handled is illustrated by an 18-in. diam vessel used in the 80 liter pilot plant runs. The vessel was operated at 550 to $600{ }^{\circ} \mathrm{C}$ during Rurss LK 26 thru 29. Then the molten salt was vacuum transferred to a steel container where it was frozen and broken up into pieces. The same vessel was then reused with the same salt for a total operating time of 148 days. Examination of the crucible after the salt had been pumped out showed spalling of the bottom, where the salt may have frozen because of heat losses through the bottom at the lowest operating temperature $\left(535^{\circ} \mathrm{C}\right)$. Similar experience was noted in the hot cell prototype operation during which a vessel lasted for seven months before being shut down at the end of the program. Vessel lifetimes in the Salt Cycle demonstration where remote handling was necessary were also long. (7)

\section{Fused Silica Vessel Failures}

If a fused silica crucible breaks, the salt corrodes through the susceptor within one day, but then the salt is imbibed by the insulation around the vessel and a frozen wall is formed. Figure 41 shows a 6-in. diam induction heated system that was operated 50 days before the silica pot broke on heating up after being frozen by a heater shutdown. The equipment was then operated for 66 hours at 600 to $735^{\circ} \mathrm{C}$ with the salt penetrating to the outside of the insulation where it remained molten in some spots but was held in the insulation by a wick effect. Twenty-liter vessels were operated in the same way without salt penetrating the insulation. The contents of the vessel were difficult to recover even though safe operation was always maintained. 


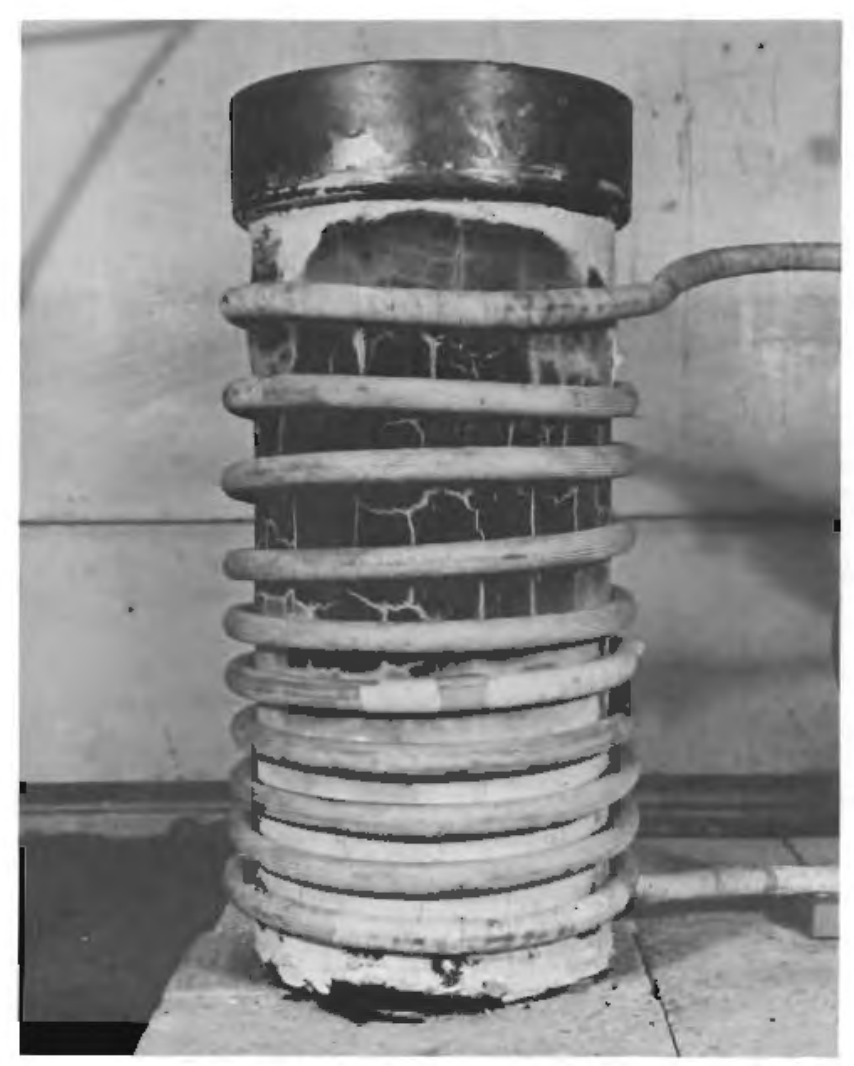

FIGURE 41

Induction-Heated System After Several Days Operation with a Broken Quartz Crucible

\section{Other Nonmetallic Materials}

Other nonmetallic crucibles were evaluated by J. H. Kleinpeter (33) to find a material that could be frozen and reheated with the salt remaining in the crucible. Most materials tested leaked salt when held at temperature for long periods. Only high density alumina did not leak salt and its mechanical properties were no better than those of quartz. Frozen Wall Systems

Systems with internal alternating current heating and metallic walls covered with frozen salt $(34,35)$ were tested. Although the heat losses were too high to permit flexible operation because of the small system size, the 60-cycle AC heating could be introduced with the same electrodes used in the electrolysis without adversely affecting the deposition of $\mathrm{UO}_{2}$. These systems were never used in the pilot plant because the solids being dissolved 
would inevitably end up in the frozen wall. This was intolerable since criticality control of plutonium was on a batch basis.

A promising frozen wall system is the one shown in Figure 42, which had an induction-heated graphite susceptor surrounded by sand inside a Transite pipe. After five days' operation at $550^{\circ} \mathrm{C}$ with $\mathrm{LiCl}-\mathrm{KCl}$ (including thermal cycling) an apparently stationary frozen wall was found about $1 / 4-i n$. into the sand outside the graphite and there was no cracking of the $3 / 4-i n$, graphite wall. Tests with graphite crucibles had previously shown that the salt leaked through the graphite in less than $24 \mathrm{hr}$.

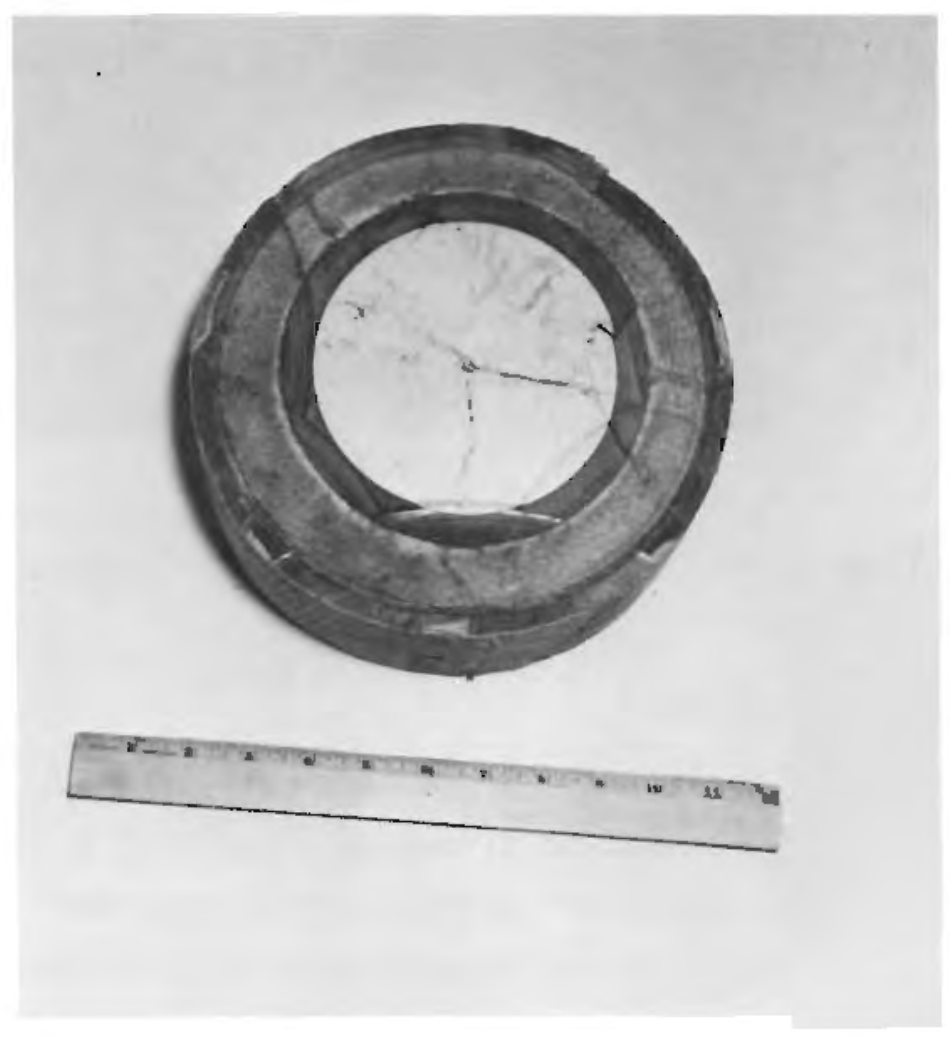

FIGURE 42

Cross Section of a Graphite Susceptor with a Frozen Wall After Several Days Operation

A similar apparatus was operated without the sand, but with a 15 psig gas pressure outside the susceptor. Although gas leaked into the crucible, salt did not leak out and stable operation was achieved.

A porous graphite crucible impregnated by barium chloride was tested in $\mathrm{LiCl}$ at $500^{\circ} \mathrm{C}$. In about five days the salt leached through the 3/4-in.-thick wall and flowed out of the crucible. 


\section{Pyrolytic-Graphite-Coated Crucibles}

Two graphite crucibles coated with pyrolytic graphite tested in LiCl-KCl at 550 to $600^{\circ} \mathrm{C}$ are shown in Figure 43. The coating was only a few mils thick on the inside of the crucible but pyrolytic graphite impregnation to at least 50 mils was obtained in the manufacturing process. " The first crucible was tested for 13 days with 2 thermal cycles to room temperature. No penetration of the crucible by the salt was detected but the air atmosphere had severely corroded the vapor space. The second crucible was operated for 13 days with an argon atmosphere and 3 thermal cycles. The crucible was apparently in perfect condition and the frozen salt block was readily removed, indicating no penetration of the wall by salt.

Although pyrolytic-graphite-costed crucibles appear to have the impermeability and mechanical strength necessary for a molten salt crucible, the chemical reactivity of graphite in the $\mathrm{LiCl}-\mathrm{KCl}-\mathrm{UO}_{2} \mathrm{Cl}_{2}-\mathrm{chlorine}$ system show in the Salt Cycle demonstration (7) makes further tests necessary to demonstrate their usefulness.

CODEPOSITION AND PARTITION

The eventual feasibility of the Salt Cycle process is dependent upon the plutonium behavior during electrodeposition. Maintaining the plutonium in its lowest valence state while electrodepositing stoichiometric $\mathrm{UO}_{2}$ is relatively simple. If the bath has been dried sufficiently, a hydrogen chloride or chlorine gas sparge will reduce the plutonium to $\mathrm{Pu}$ (III) or $\mathrm{Pu(IV)}$ and prevent it from codepositing with the $\mathrm{UO}_{2} \cdot$ Codeposition of $\mathrm{UO}_{2}$ and $\mathrm{PuO}_{2}$, on the other hand, is more difficult because the oxidizing conditions required to produce $\mathrm{Pu}(V I)$ might not be suitable for producing stoichiometric $\mathrm{UO}_{2}$ and $\mathrm{Pu}(\mathrm{VI}) \mathrm{might}$ be reduced in solution near the cathode without depositing. The production of nonstoichiometric $\mathrm{UO}_{2}$ in itself, while not desirable, is not intolerable because the mixed oxide product can be hydrogen-reduced. However, if the oxygen-to-uranium ratio is higher than 2.1 , a porous deposit will result and high density fuel elements will not be possible.

*These crucibles were produced by the Metallurgicel Products Dept. of the General Electric Company, Detroit Michigan. 


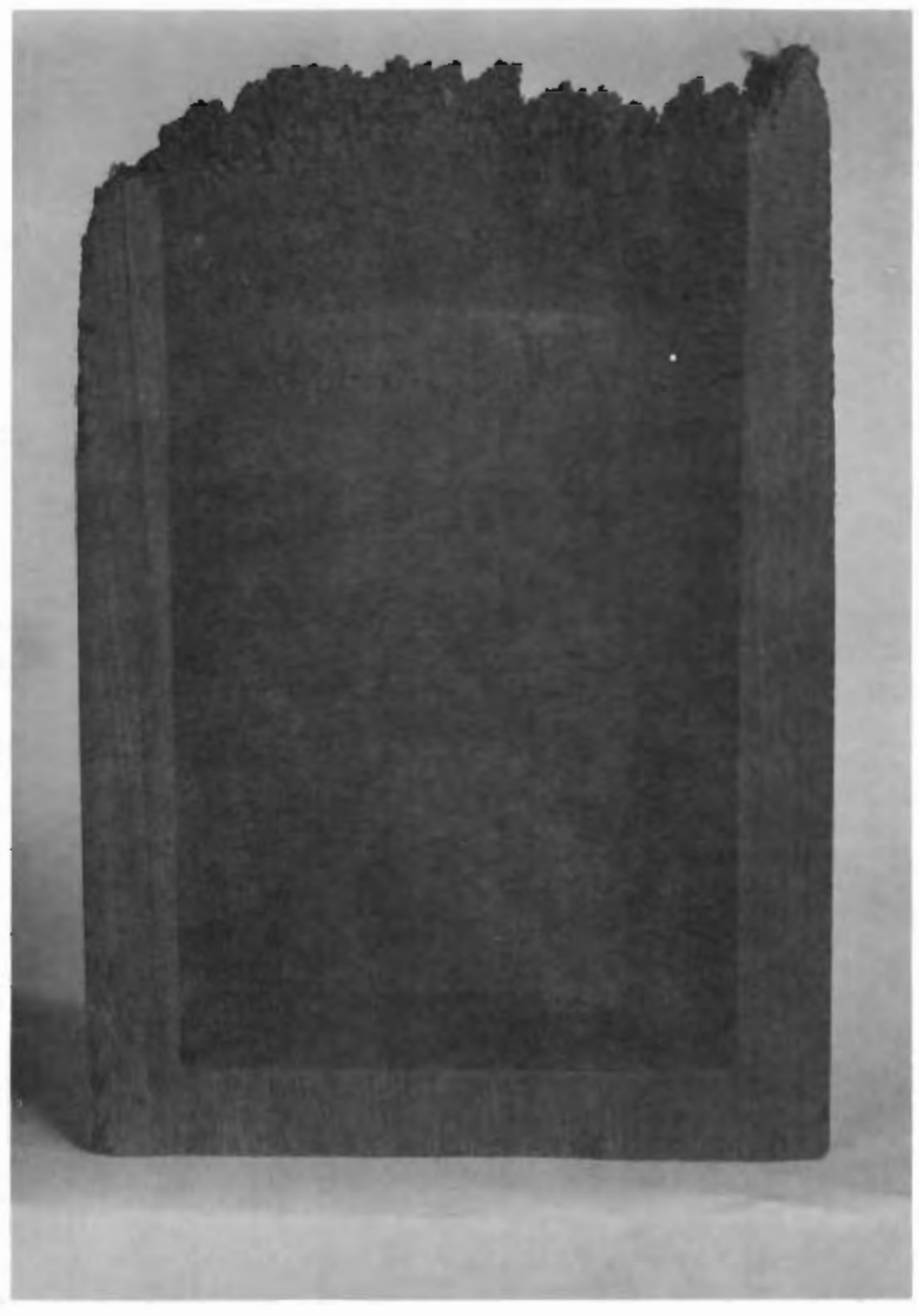

In an Air Atmosphere

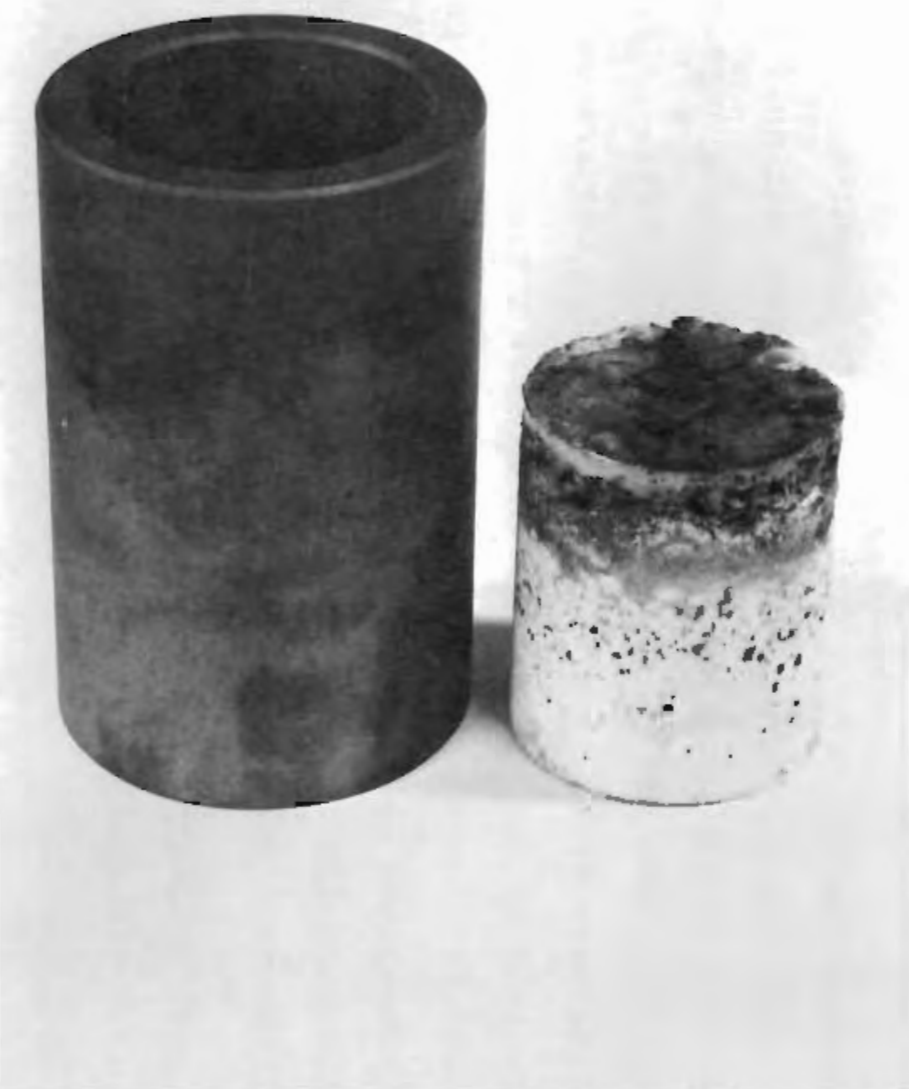

In an Argon Atmosphere $\stackrel{\leftrightarrow}{\circ}$

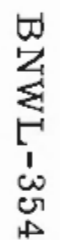

Pyrolytic Graphite Crucibles After Testing at $600{ }^{\circ} \mathrm{C}$ for 13 Days 
Since the pilot plant facility was not equipped to handle the contamination from plutonium, a series of tests was conducted with cerium stand-in for plutonium. At the time of the tests cerium was believed to behave more closely to plutonium in codeposition than any other element because of its potential ability to be oxidized from a relatively stable Ce(III) state to a relatively unstable $\mathrm{Ce}$ (IV) state by chlorine-air mixtures. Later hot cell experience in the Salt Cycle demonstration (7) suprisingly showed that the behavior of the trivalent rare earths yttrium and europium was much closer than to that of plutonium, and that DF's of 10 could be obtained for cerium in codeposition of plutonium with uranium.

\section{Cerium Stand-In for Plutonium}

The cerium stand-in runs are summarized in Table XVIII. A salt charge of about $6 \mathrm{~kg}$ was made up to the composition equimolar $\mathrm{LiCl}-\mathrm{KCl}, 20 \mathrm{wt} \%$ uranium and $I$ wt\% cerium. The uranium was introduced as $\mathrm{UO}_{2} \mathrm{Cl}_{2} \cdot \mathrm{H}_{2} \mathrm{O}$ and the cerium was introduced as $\mathrm{CeCl}_{3} \cdot 7 \mathrm{H}_{2} \mathrm{O}$. Cerium-144 tracer was added as $10 \mathrm{ml}$ of aqueous solution. The bath was sparged with hydrogen chloride gas until dry by the microelectrode test (page 51). Electrolyses were conducted at $1.5 \mathrm{~V}$ and $530{ }^{\circ} \mathrm{C}$ with about $25 \%$ of the uranium deposited in each run. Material balances on the tracer were poor; as much as half of it was lost, but the material balances on the bulk cerium were good.

Runs CTC-1 and CTC-2 show that either hydrogen chloride or chlorine sparges could prevent cerium from codepositing with the $\mathrm{UO}_{2}$ with a decontamination factor of 15 to 20. A 50 vol\% chlorine-50 vol\% air sparge produced a cerium DF less than 5, and an oxygen-to-uranium ratio less than 2.01. Figure 44 shows the type of deposit produced under these conditions, which eventually proved to be the best for codepositing $\mathrm{PuO}_{2}$ with $\mathrm{UO}_{2}$ in the Salt Cycle demonstration. $(6,7)$ An air sparge also produced low cerium DF's as shown in Runs CTC -4 and $C T C-6$ but resulted in high $0 / U$ ratios up to 2.08 . An attempt at continuously dissolving $\mathrm{U}_{3} \mathrm{O}_{8}$, by placing the $\mathrm{U}_{3} \mathrm{O}_{8}$ in a hollow graphite anode with holes drilled in it,resulted in a deposit with a low cerium DF and a high oxygen-to-uranium ratio. An electrolysis with a chlorine sparge that had been bubbled through water also produced a high $O / U$ ratio and a low cerium DF. In a high temperature $\left(700^{\circ} \mathrm{C}\right)$ partition electrolysis the graphite anodes were corroded 
TABLE XVIII

\section{CERIUM STAND-I. FOR PLUTONIUM IN UO 2 DEPOSITION}

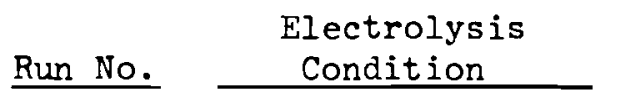

CTC-1

CTC-2 Chlorine sparge

CTC-3 50 vol\% $\mathrm{Cl}_{2}-$

50 vol\% air sparge

CTC-4 Air sparge

CTC-5 $\mathrm{U}_{3} \mathrm{O}_{8}$ basket anode, no sparge

CTC-6 Air sparge

CTC-11 Wet chlorine sparge

CTC-12 High temperature partition

\section{Intermittent Electrolyses}

$\begin{array}{ll}\text { CTC-7 } & \mathrm{Cl}_{2} \text { sparge } \\ \text { CTC-9 } & 50 \text { vol\% } \mathrm{Cl}_{2}- \\ & 50 \text { vol\% air sparge }\end{array}$

CTC-10 Air sparge

* Side away from the sparge

Feed to Deposit Cerium Decontamination Factor

Tracer Chemical

Analysis Analysis

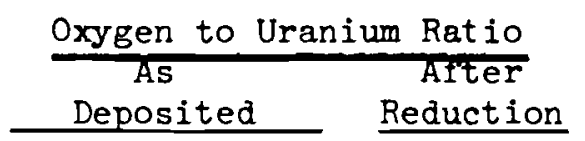

$\begin{array}{ll}22.9 & 20.1 \\ 14.1 & 14.1\end{array}$

4.2

4.8

$1.66,2.55^{*}$

$4.3,9.3 * 2.0777,2.0202 *$

2.0021

2.0016

$$
1.869 .3,13.9
$$

2.060

$1.1, \quad 1.5^{*}$

$4.5,7.6^{*} 2.0304,2.0079 *$

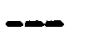

2.9

2.8

$2.062 ?$

2.0162
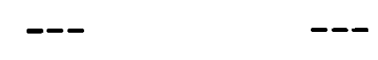

2.0019

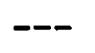

\section{6}

$>22$

$? .0048$

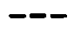

2.0059

2.0585
5.3

3.7

2.1520

3.0

\begin{tabular}{|c|c|}
\hline $\begin{array}{c}\text { As } \\
\text { Deposited }\end{array}$ & $\begin{array}{c}\text { After } \\
\text { Reduction }\end{array}$ \\
\hline
\end{tabular}

2.0714
10.777

10.546

$10.849,10.890 *$

$10.541,10.891 *$

10.781

$10.893 \quad 10.807 \stackrel{\circ}{\circ}$

$10,772,10,771 *$

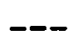

10.621

10.813

10.911

$---$ 


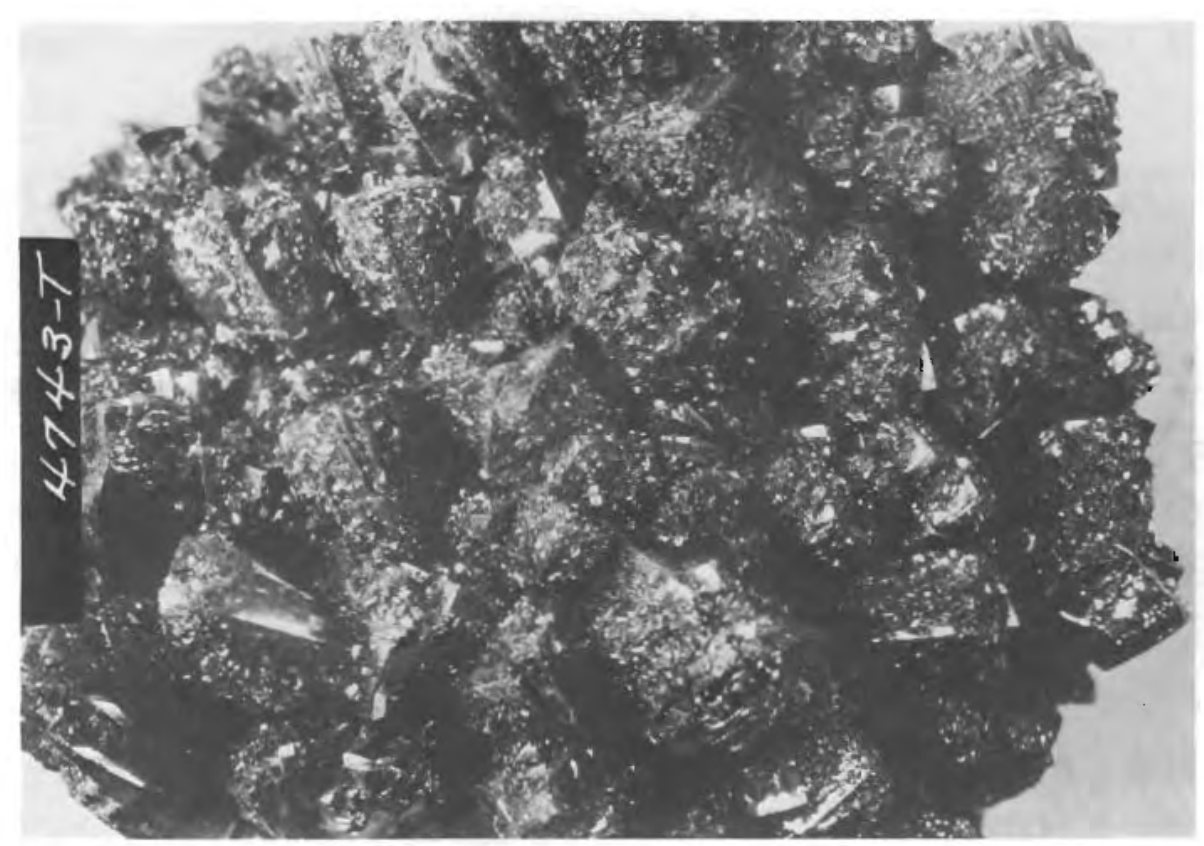

CTC-3 Growing Surface
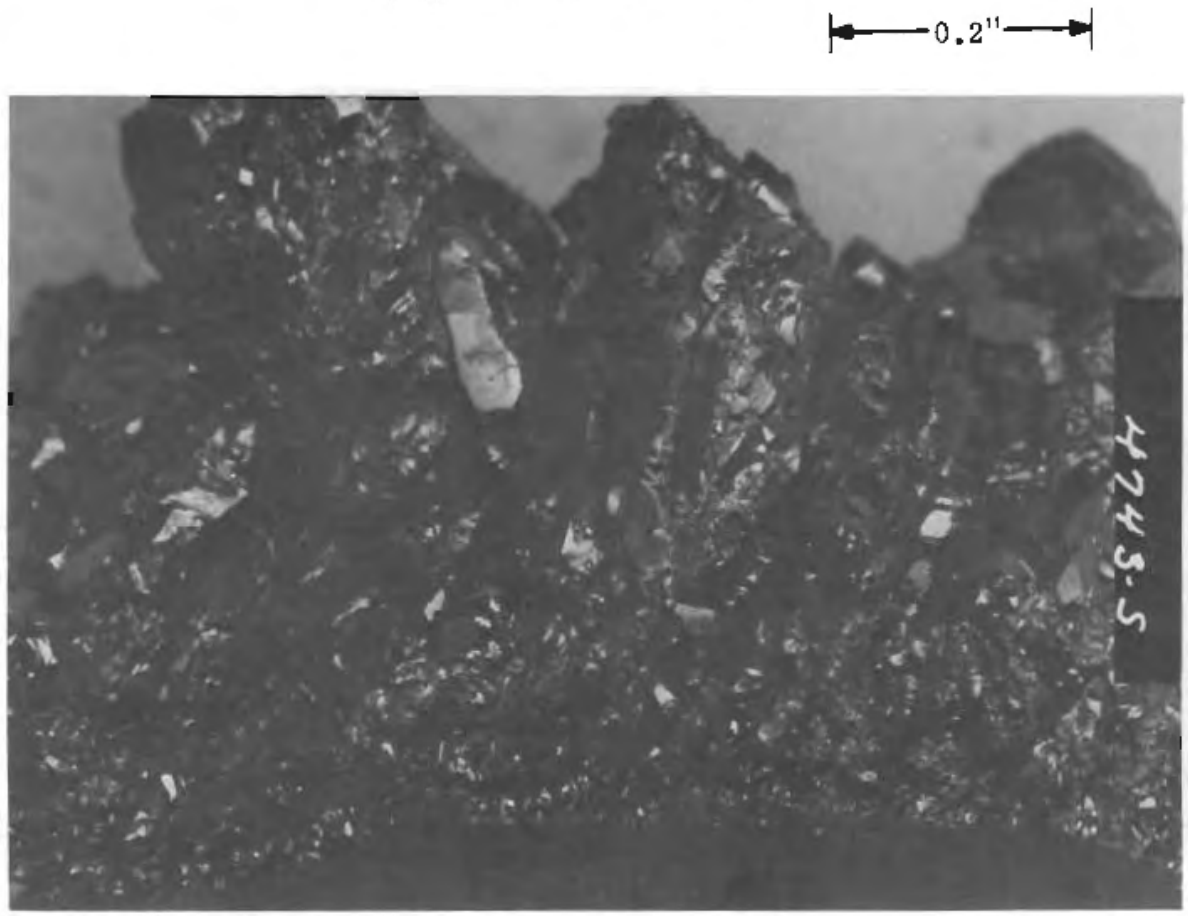

CTC-3 Cross Section

FIGURE 44

Codeposit with 50\% Oxygen - 50\% Chlorine Sparge 
off at the liquid-gas interface by air entering the vapor space. The cerium $\mathrm{DF}$ in this run was high and the $\mathrm{UO}_{2}$ produced was compact and crystalline (Figure 45).

An attempt to increase the quantity of $\mathrm{Ce}$ (IV) in solution was made by electrolyzing intermittently with the current alternately on for one minute and off one minute. The oxidizing gases increased the $O / U$ ratio of the product much more with an intermittent electrolysis, but the cerium DF was not significantly affected. The crystal structure is a stronger function of sparge gas used than with continuous electrolyses, as shown in Figure 46. The on-off cycles are easily visible in the deposit from Run CTC-7. Hydrogen reduction of the CTC-9 product with an O/U ratio of 2.07 was accomplished without significantly changing the crystal structure and the density. The product of Run CTC-Il with air sparging is clearly unsuitable for making $-4+10$ mesh particles.

\section{Codeposition of Nickel-UO 2 Cermet}

During the preliminary experiments in the hot cell before startup of the Salt Cycle demonstration, an electrolysis was performed in a LiCl-KCl salt bath containing uranium, plutonium and products of corrosion of a Hastelloy $B$ susceptor. The fused silica vessel had broken a few days before the electrolysis and appreciable nickel was dissolved in the bath. The salt before electrolysis contained $0.84 \mathrm{wt} \% \mathrm{U}, 1.6 \mathrm{wt} \% \mathrm{Ni}$ and $0.04 \mathrm{wt} \% \mathrm{Pu}$. The electrolysis was conducted at $530^{\circ} \mathrm{C}$ with graphite electrodes at $2.0 \mathrm{~V}$ and $1.7 \mathrm{amp} /$ in. $^{2}$ current density at the cathode with a $50 \% \mathrm{Cl}_{2}-50 \% \mathrm{O}_{2}$ gas sparge. After electrolysis the salt contained $1.0 \mathrm{wt} \% \mathrm{U}$ (an increase!) and $0.021 \mathrm{wt} \% \mathrm{Ni}$. Analysis of the product by weight gave $0.52 \% \mathrm{Pu}, 65 \% \mathrm{Ni}, 29.6 \% \mathrm{U}, 2.2 \% \mathrm{MO}$, $0.12 \% \mathrm{Fe}, 0.33 \% \mathrm{Cl}, 0.04 \% \mathrm{Li}$, and an $0 / \mathrm{U}$ ratio of 2.094 . Examination of photomicrographs of the product showed it to be a probable mixture of nickel metal and $\mathrm{UO}_{2}$ with appreciable dispersion of $\mathrm{UO}_{2}$ in a nickel matrix. The nickel tended to be continuous and filament-like, containing globules of $\mathrm{UO}_{2}$. The deposit was very porous and not macroscopically homogeneous, with the nickel concentrated at the inner and outer surfaces of the deposit. The results of this experiment do not seem to agree with the results shown in Table XIII (page 77 ) in which very high nickel decontamination factors were 


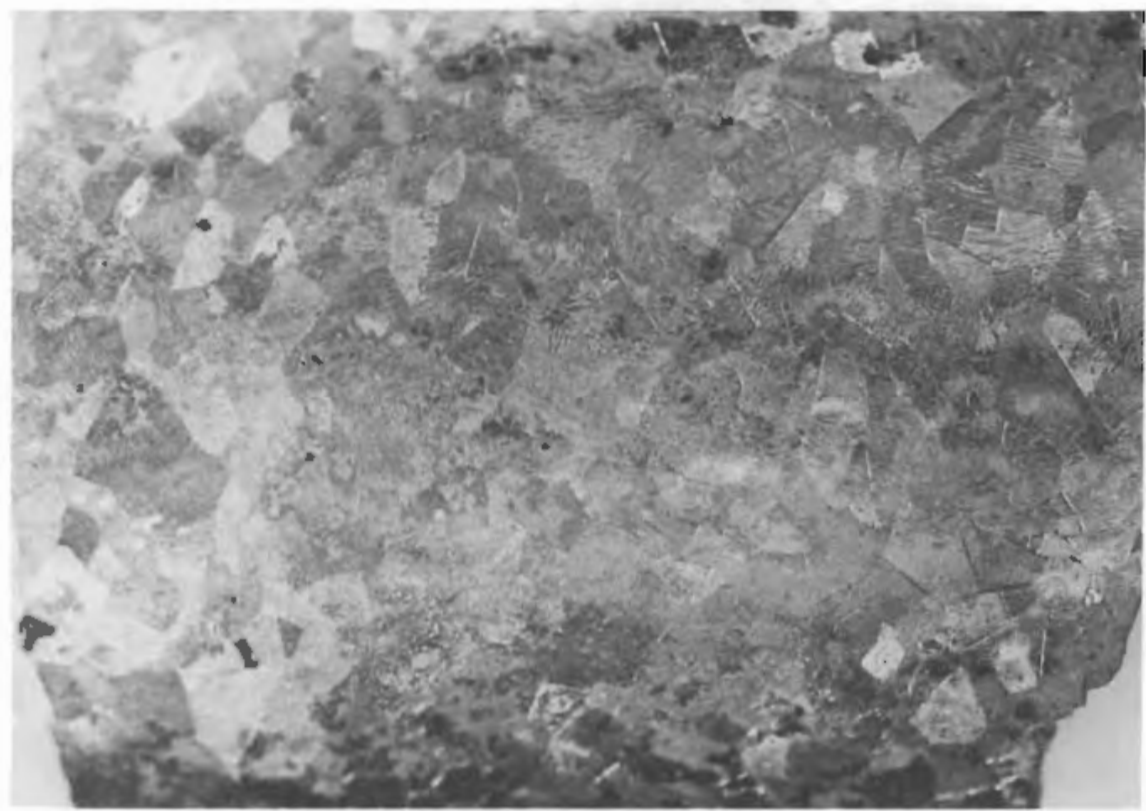

CTC-12 Growing Surface
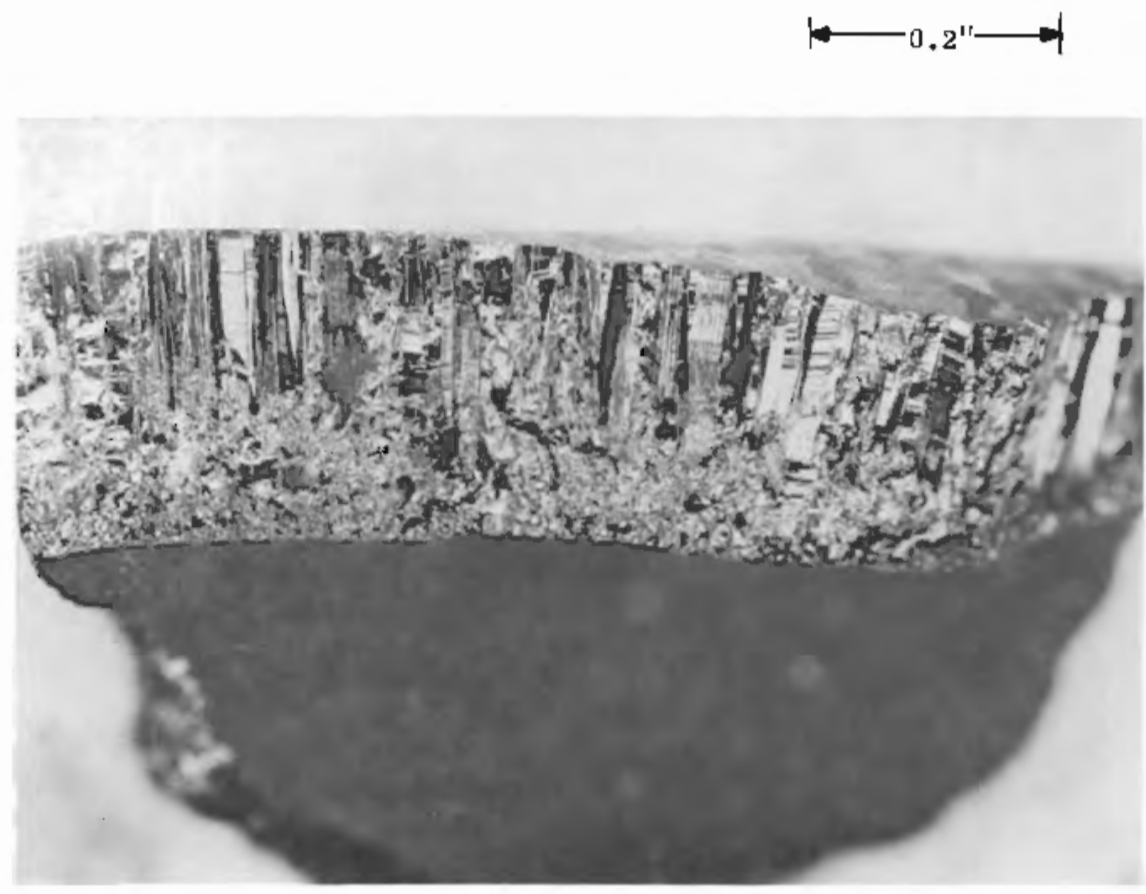

CTC-12 Cross Section

FIGURE 45

Deposit from a High Temperature Partition 


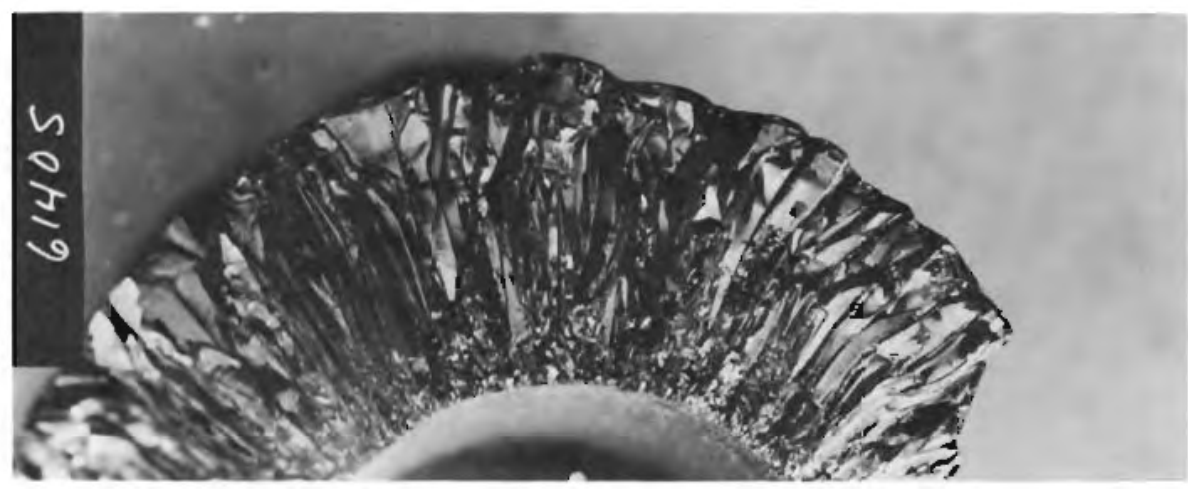

Chlorine Sparge

Run CTC-7
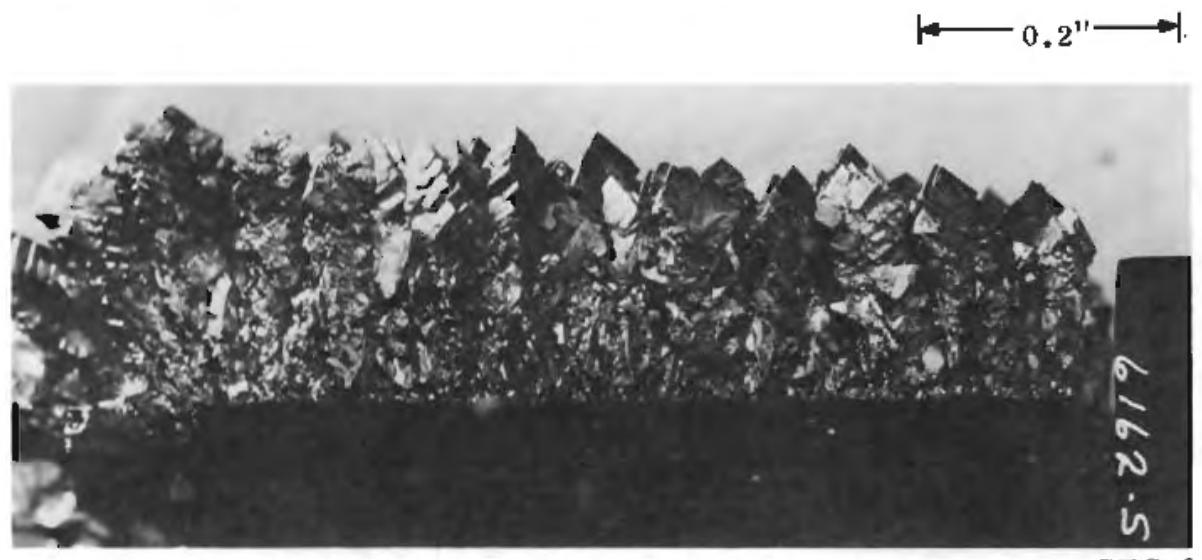

Chlorine-Air Sparge

Run CTC-9

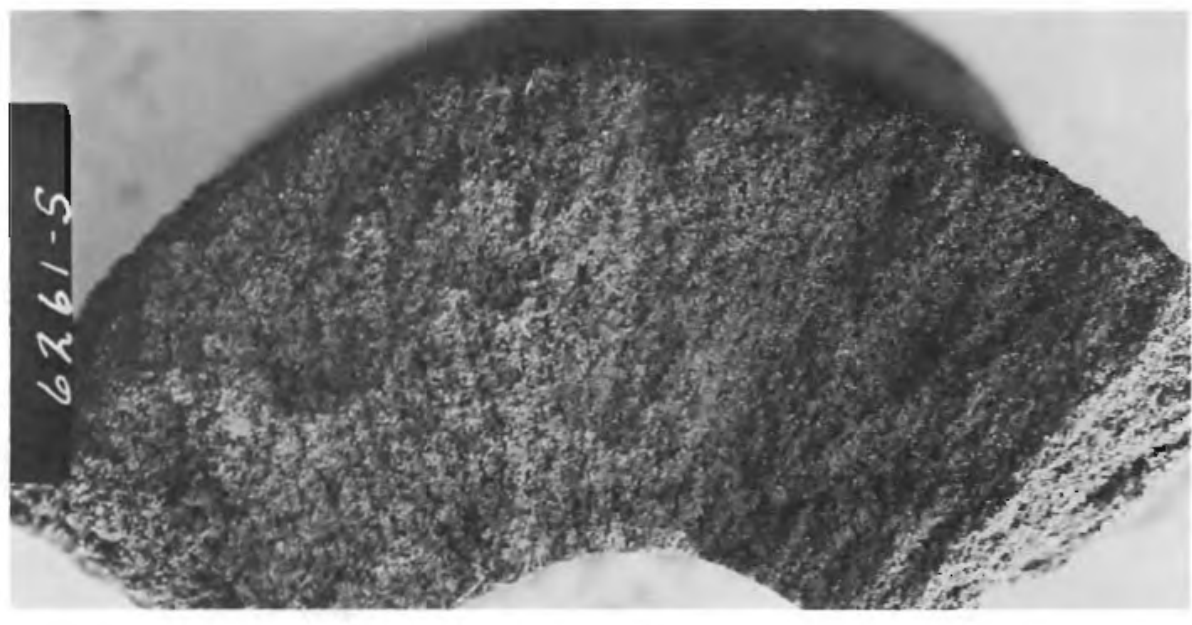

Air Sparge

Run CTC-10

FIGURE 46

Codeposits with Intermittent Electrolyses 
obtained, although the operating conditions were somewhat different, Further work might result in the development of a method for producing $\mathrm{UO}_{2}$ or $\mathrm{UO}_{2}-\mathrm{PuO}_{2}$ cermets that are suitable for use as nuclear fuels.

PRECIPITATION

Several flowsheets for the Salt Cycle process include precipitation of plutonium from the molten salt as a means for producing a dense, crystalline $\mathrm{PuO}_{2}$ product directly or as a step for achieving the necessary rare earth decontamination factors for a codeposited, mixed $\mathrm{UO}_{2}-\mathrm{PuO}_{2}$ product. Since plutonium could not be used in the development facility, cerium and thorium were used as stand-ins. The means for recovery of the precipitate from the vessel was studied rather than the formation of the precipitate because the $\mathrm{PuO}_{2}$ immediately forms an easily filterable precipitate, ${ }^{(6)}$ and because the chemical behavior of cerium and thorium are somewhat different from that of plutonium in molten salts.

Freeze-Valve Technique

A freeze-valve technique was tested briefly to remove precipitate from the molten salt bath. The quartz vessel had an open quartz tube extending through the bottom of the induction furnace into a separately controlled heating zone. The molten salt fills this tube and is allowed to freeze, sealing the bottom of the vessel. The molten salt can be drained from the vessel by melting the salt plug in the tube. It then passes through a quartz frit filter, and the precipitate is recovered by aqueous washing after the filter cools. The frozen salt plug is reestablished after incremental quantities of molten salt have been drained from the vessel. Only two tests were conducted with this apparatus. In the first test the frozen plug was established below a vessel containing a $\mathrm{UO}_{2}$ slurry. The plug was then melted, draining the vessel and collecting the $\mathrm{UO}_{2}$ on a quartz frit. The second test resulted in breakage of the quartz tube during melting of the frozen plugo

\section{Thorium Stand-In for Plutonium}

Thorium was a poor stand-in for plutonium in the study of $\mathrm{PuO}_{2}$ precipitation procedures from the $2.5 \mathrm{LiCl}-\mathrm{KCl}$ molten salt system. Good precipitation of thorium was not achieved because the $\mathrm{ThO}_{2}$ formed a slurry rather than 
settling rapidly as does $\mathrm{PuO}_{2}$. A $40 \% \mathrm{O}_{2}-60 \% \mathrm{Cl}_{2}$ reactant gas mixture was contacted through a filter of $-50+100$ mesh quartz sand for $7 \mathrm{hr}$ at $570{ }^{\circ} \mathrm{C}$ with a recovery of only $5 \%$ of the thorium on the filter. Material balances indicated that $50 \%$ of the thorium was precipitated as $\mathrm{ThO}_{2}$, and therefore the filter efficiency was about $10 \%$.

\section{Cerium Stand-In for Plutonium}

Equipment for the recovery of plutonium as $\mathrm{PuO}_{2}$ from a molten $\mathrm{LiCl}-\mathrm{KCl}$ salt solution by treatment with oxygen-chlorine was tested using cerium as a stand-in for plutonium. The cerium was precipitated from a $2.5 \mathrm{LiCl}-\mathrm{KCl}$ mixture containing 10 wt $\mathrm{U}$ and 0.63 wt $\%$ Ce by gas-lifting with a $60 \% \mathrm{Cl}_{2}-$ $40 \% \mathrm{O}_{2}$ gas mixture through a filter assembly. The filter assembly consisted of three $30 \mathrm{~mm}$ diam quartz-tube chambers with quartz-frit bottoms through which the molten salt cascaded in series, finally overflowing the third chamber. The $\mathrm{CeO}_{2}$ precipitate settled in all the chambers and adhered to the quartz tubing and frits. Approximately 50\% of the precipitate was recovered with the above filter arrangement; however, since only $24 \%$ of the cerium was precipitated, a good test of the filter arrangement was not obtained. The precipitate was crystalline and black in color and did not form a stable suspension in either water or the molten salt as did $\mathrm{ThO}_{2}$. The cascading filter apparatus failed after three runs because of cracks apparently caused by attack on the quartz by the chlorine-oxygen, fused-salt mixture. Bonding of the $\mathrm{CeO}_{2}$ precipitate to the quartz may also have promoted weakering of the quartz.

A recirculating gas lift was tested at $580^{\circ} \mathrm{C}$ to determine how much $\mathrm{CeO}_{2}$ could be collected on this piece of equipment alone. The gas lift consisted of two concentric pieces of quartz, $51 \mathrm{~mm}$ and $10 \mathrm{~mm}$ in diameter, the $51 \mathrm{~mm}$ tube tapered to a $20 \mathrm{~mm}$ opening at the bottom. Gas was admitted through the $10 \mathrm{~mm}$ tube. A $24-\mathrm{hr} 70 \% \mathrm{O}_{2}-30 \% \mathrm{Cl}_{2}$ treatment resulted in precipitation of $85 \%$ of the cerium and recovery of $43 \%$ of the cerium on the apparatus. Most of the recovered $\mathrm{CeO}_{2}$ was deposited on the sloping surface where the $51 \mathrm{~mm}$ tube narrowed to a $20 \mathrm{~mm}$ opening and was removed by soaking in $0.5 \mathrm{MNO}_{3} \mathrm{H}^{\circ}$ 
Direct precipitation of $\mathrm{CeO}_{2}$ on the bottom of the vessel by sparging was followed by gas lifting of the salt through a filter to recover the precipitate. Comparison of the $\mathrm{CeO}_{2}$ precipitation experiments with previous work on plutonium (6) showed that $80 \%$ of the cerium would be precipitated as $\mathrm{CeO}_{2}$ under the same conditions for which greater than $90 \%$ of the $\mathrm{Pu}$ had been precipitated as $\mathrm{PuO}_{2}$. However, operation for $23 \mathrm{hr}$ with a $50 \% \mathrm{Cl}_{2}-50 \% \mathrm{O}_{2}$ gas lift precipitated only $60 \%$ of the cerium. A graphite filter was substituted for the usual quartz assembly with the result that only $8 \%$ of the cerium was precipitated after the $23-\mathrm{hr} 50 \% \mathrm{Cl}_{2}-50 \% \mathrm{O}_{2}$ gas lift treatment. Attack on the graphite was noted, indicating a possible redissolution of the $\mathrm{CeO}_{2}$ by reaction with chlorine and carbon。

The tenacious adherence of $\mathrm{CeO}_{2}$ and $\mathrm{PuO}_{2}$ to the quartz suggested the use of a high porosity filter consisting of a quartz Gooch crucible filled with large quartz chips to pick up the $\mathrm{CeO}_{2}$. With this apparatus a $60 \% \mathrm{O}_{2}-40 \% \mathrm{Cl}_{2}$ sparge through the gas lift precipitated $90 \%$ of the cerium, and about $70 \%$ of that precipitate was recovered on the filter and the gas lift. The $\mathrm{CeO}_{2}$ was removed from the quartz by washing in $8 \mathrm{M} \mathrm{HNO}_{3}-0.2 \mathrm{MF}$ solution. $\mathrm{A} 10 \mathrm{wt} \%$ $\mathrm{NaOH}$ solution was also found to be effective for removal. The success of only these methods indicates that the $\mathrm{CeO}_{2}$ is removed only by attack on the quartz. A sieve analysis of the product yielded $10 \%+100$ mesh and $56 \%$ $-100+200$ mesh particles. X-ray analysis of the $\mathrm{CeO}_{2}$ product showed that the precipitate from a $2.5 \mathrm{LiCl}-\mathrm{KCl}$ mixture containing $10 \mathrm{wt} \% \mathrm{U}$ and $0.63 \mathrm{wt} \%$ Ce was comprised of $91 \% \mathrm{CeO}_{2}$ and $9 \% \mathrm{UO}_{2}$ as a solid solution with diffraction lines of $\mathrm{CeO}_{2}$. Breakage caused by quartz corrosion during $\mathrm{CeO}_{2}$ precipitation made it necessary to replace the filter apparatus after two runs.

In all, six precipitation runs were made in the 20 liter salt bath containing $2.5 \mathrm{LiCl}: 1 \mathrm{KCl}$ molten salt. Of the various recirculation devices designed to collect the $\mathrm{CeO}_{2}$ which were operated with a $\mathrm{Cl}_{2}-\mathrm{O}_{2}$ sparge, the design that gave the best recovery (65\%) was the simple bed of quartz chips through which the molten salt was circulated. An overall analysis of the six runs showed that $248 \mathrm{~g}$ of cerium were recovered, and $32 \mathrm{~g}$ of cerium remained in solution. This means that $110 \mathrm{~g}$ of cerium was lost, probably by plating of the cerium on the quartz pot above the surface of the molten salt solution. 
A large quantity of black material $\left(\mathrm{CeO}_{2}-\mathrm{UO}_{2}\right)$ was visible at this location. This plating problem would not be as acute in the 1:l $\mathrm{KCl}-\mathrm{LiCl}$ system, although the precipitation itself also would not be as complete.

The chief difficulty in all the tests was the precipitation of $\mathrm{CeO}_{2}$ and probably $\mathrm{PuO}_{2}$ as later shown in the Salt Cycle demonstration, (7) on surfaces where it was not desired. Experiments with a graphite liner were conducted to prevent precipitation of $\mathrm{CeO}_{2}$ on the quartz vessel walls. This was apparently successful in short term tests, but the chlorine-oxygen atmosphere produced severe corrosion during several weeks of operation. Possibly, a chlorine-oxygen gas lift operating in this system would recover more precipitate on the filter than in unlined vessels. CRUSHING AND SIEVING

To demonstrate recycle of fuel to the reactor, it was necessary to develop remotely operable equipment to produce mixed oxide of the proper particle size for vibratory compaction. A goal was set to develop equipment to produce a $\mathrm{UO}_{2}$ product with $60 \%-4+10 \mathrm{mesh}, 20 \%-35+65 \mathrm{mesh}$, and $20 \%-200$ mesh particles, a 3-size mix which was ideally suited for vibratory compaction.

Early work was done with a wet crushing and screening system because of the possibility of scattering radioactive dust about the cell in dry methods. However, its development was not far enough along to guarantee success in the Salt Cycle demonstration with the time schedule available. An Iler $\mathbb{B}_{\text {Disc }}$ Pulverizer with eccentric rotating discs was evaluated and met the product specifications, but there was not room enough to put it in the hot cell and there was some doubt whether it could be operated remotely. Further tests were conducted with a press-type crusher which could also be used to strip oxide from the electrodes and to cut up cladding for disposal. This proved suitable for producing the coarse and intermediate size fractions. A multipurpose pulverizer was also developed to produce the fines fraction, sieve the product, and blend the size fractions together. However, a separate sieve shaker and ball milling of the fines were eventually selected for use in the Salt Cycle demonstration. ( 7 )

(B) The Fen Machine Company, Wickliffe, Ohio 
Wet Crushing and Sieving System

An integrated system was assembled and operated to study remote crushing, screening, and washing of electrolytically-deposited $\mathrm{UO}_{2}$ in a completely wet system. The equipment shown in Figure 47 contained the following major components :

1. A motor-driven single-roll crusher consisting of four 4-in.-diam, staggered-tooth milling cutters mounted on a keyed shaft. Fixedclearance grate bars (1/8-in.) blocked passage of oversize particles.

2. A double-deck Novo* screen, with two flat, inclined screens driven by an electromagnetic coil. Four screens were used in two combinations: 3 and $30 \mathrm{mesh}$, and 100 and $200 \mathrm{mesh}$.

3. A closed loop washing system consisting of a wash column, a pump and a 3-in.-diam x 12-in.-long hydroclone, the underflow of which fed the screen.

During operation of the system, 2- to 3-in.-long slabs of $\mathrm{UO}_{2}$ are fed to the crusher and pulverized particles are dropped through to the wash column below. By closing the crusher discharge valve and throttling the pump discharge, the particles are washed by an upward moving stream of water. Increasing the water flow fluidizes the $\mathrm{UO}_{2}$, carrying particles to the screen for classification. Processing $150 \mathrm{lb}$ of $\mathrm{UO}_{2}$ in the integrated system gave satisfactory performance except as noted below.

With 1/8-in. grate bar clearance a typical product consisted of $60 \%$ $-6+30$ mesh, 95\% $-3+200$ mesh, and 5\% -200 mesh particles. The product could be coarsened by increasing grate bar clearance, but the narrow particle size ranges desired for fuel refabrication were not achieved in these studies.

Good classification of -200 mesh particles was not achieved in the wet system, particularly when using the 200 mesh screen. As a result, the finer particles tended to become distributed throughout the system. In general, hydraulic transport of crushed $\mathrm{UO}_{2}$ appears to offer advantages of good dust control, process flexibility, and contamination control, particularly if washing is required as a normal part of the process. However, the relatively large volumes of water required may be objectionable.

*

Hovo Industrial Corp., Chicago, Illinois. 

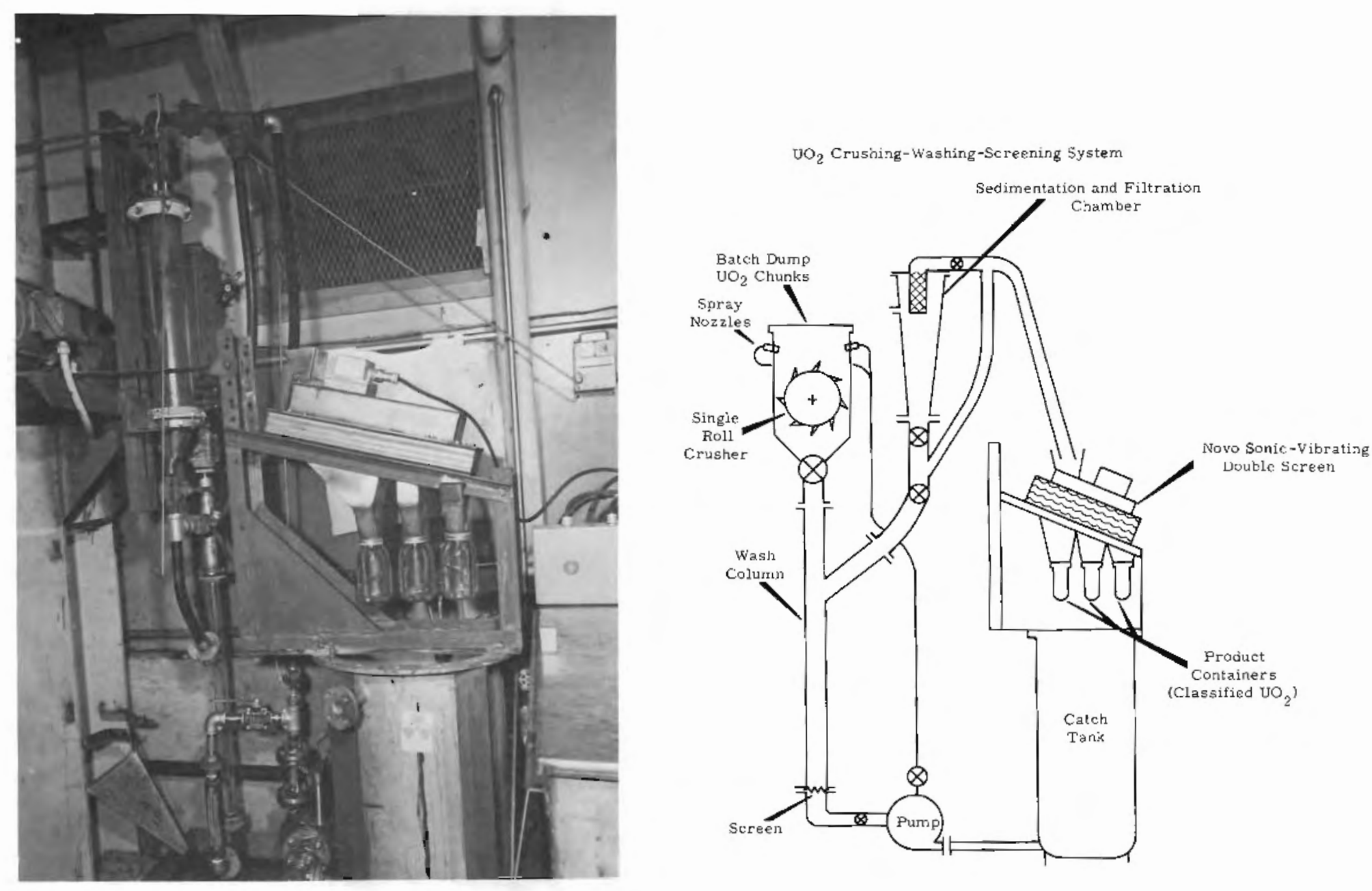

Wet Crushing and Sieving System 


\section{Iler Disc Pulverizer}

The disc pulverizer has one fixed and one rotating disc as is shown in Figure 48. The fixed disc oscillates against the revolving disc in a vertical motion. The degree of fineness of the product is regulated by manually rotating the shaft guide for the rotating disc to charge the gap between the discs.

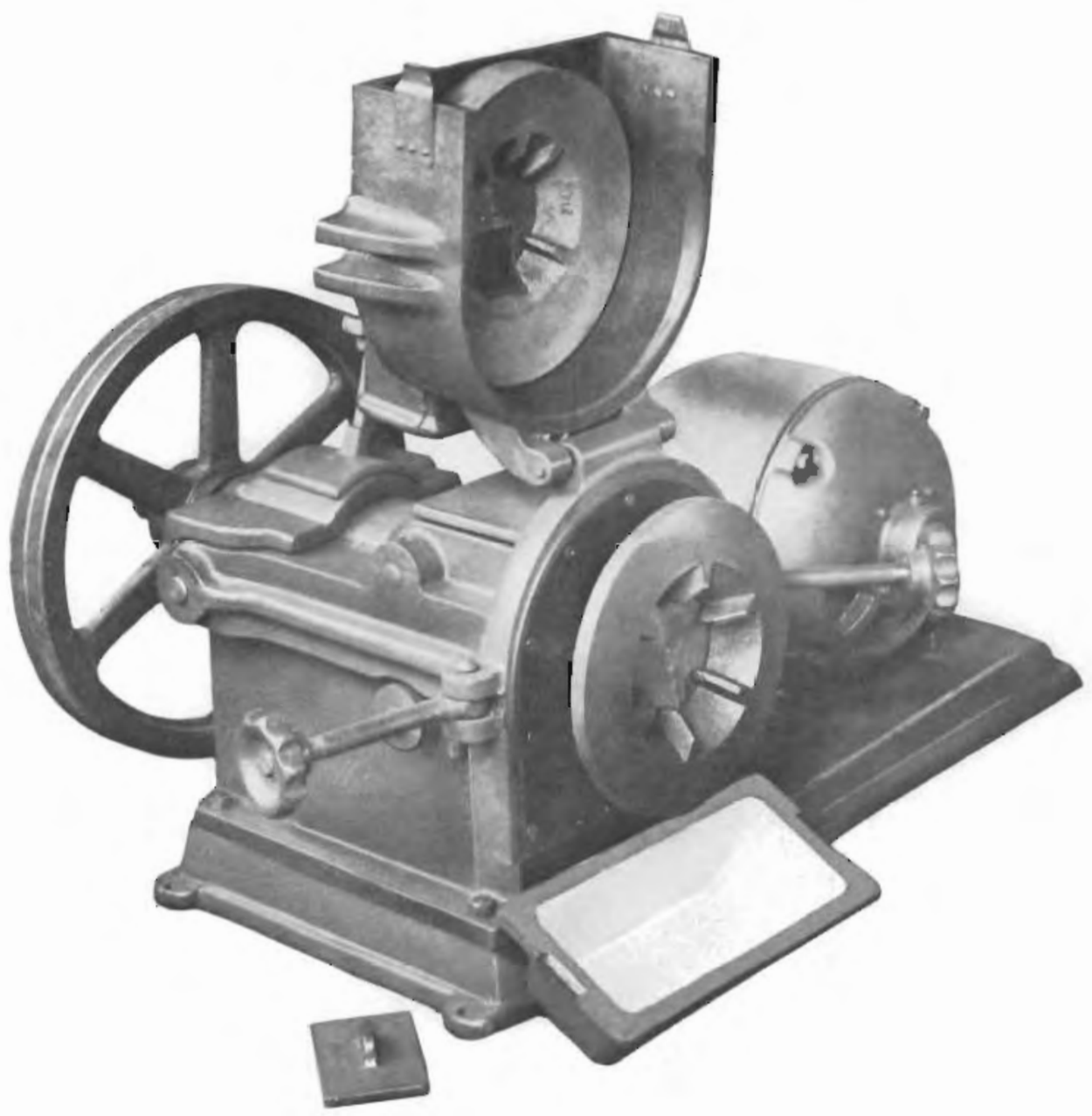

FIGURE 48

Iler Disc Pulverizer

A calibration of the apparatus for electrolytic $\mathrm{UO}_{2}$ at $557 \mathrm{rpm}$ with a choke feed is given in Figure 49. The numbered settings are arbitrary and will vary with the machine and the numbering system used. For electrolytic $\mathrm{UO}_{2} \mathrm{a} \mathrm{No} .41$ setting gives 3-mesh particles and a No. 25 setting gives 8-mesh particles, 


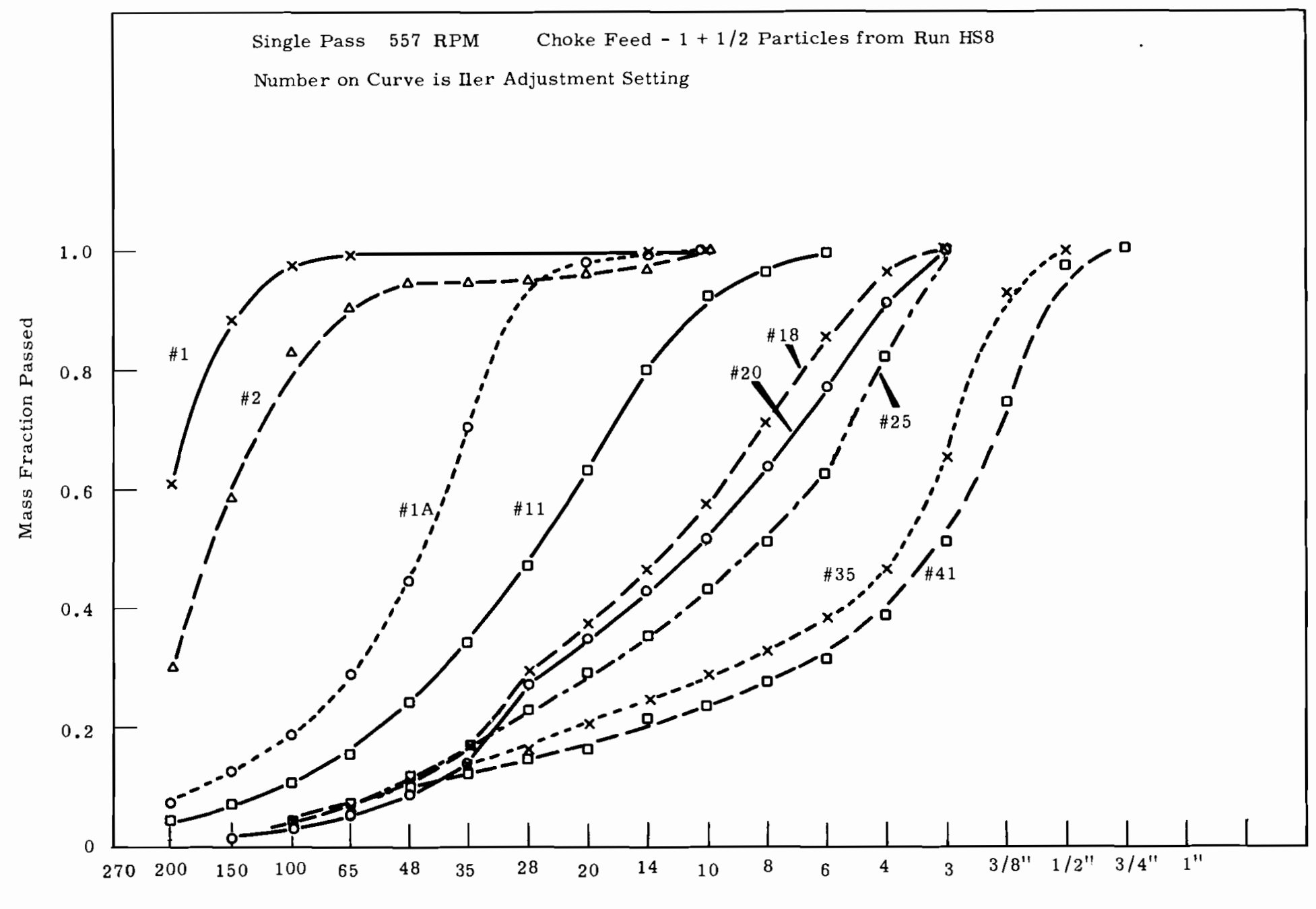

Tyler Screen Mesh

FIGURE 49

Variation of Gap Between Discs - Product from Iler Disc Pulverizer 
using the $50 \%$ mass fraction as an indicator. Iess than 200-mesh particles can be obtained with very fine settings。 Changing from choke feeds with the hopper full of $1 / 2-i n$ o to $3 / 4-i n$ o chunks to single particle feed increased the median particle size by 1.4 times for approximately 20 -mesh product but did not alter the sharpness of the size distribution significantly。

The most difficult part of achieving the desired particle size distribution is to get the largest fraction of the product in the relatively narrow size range $-4+10$ mesh。 Reducing the speed of the crusher from the standard $557 \mathrm{rpm}$ to $40 \mathrm{rpm}$ greatly sharpens the peak of the size distribution as is shown in Figures 50 and 51 . Further speed reduction to 7.8 rpm has little effect. Nonreproducibility of feed material is also a strong factor in the product obtained. Although the $\mathrm{UO}_{2}$ products of electrolysis Runs $\mathrm{HS}-8$ and HS-5 appear to be nearly identical in all other ways, the HS-8 material clearly degrades more easily and does not produce a narrow size range product. A second characteristic of HS- 8 product which is not due to the disc pulverizer is the appearance of a secondary peak at 35 mesh. This peak occurred only at the finer No, 18 setting and is reproducible. From the results of the screening of the $\mathrm{NaCl}-\mathrm{KCl}$ product (Figure 17, page 44), it is known that such secondary peaks may be due to the presence of agglomerates of this size crystal in the as-despoited $\mathrm{UO}_{2}$, which break down on crushing. Microscopic examination of the deposits show that such agglomerates tend to form in the first layer of $\mathrm{UO}_{2}$ deposited, near the electrode in wet or impure melts。 Since this secondary peak is very close to the size of the desired intermediate particle size, control of the size and location of this peak could greatly simplify required crushing operations.

Moisture will be present in the $\mathrm{UO}_{2}$ if the deposit is not stored in a dry atmosphere because the lithium chloride in the adherent and occluded salt is hygroscopic. The effect of moisture picked up by LiCl on crushing and screening operations is shown in Figure 52. The fine particles below 30 mesh agglomerate, producing a characteristic step in the particle size distribution curve. Agglomeration of fines is desirable to reduce radioactive dust formation, but fines adhering to larger particles could alter the size distribution in the final mix, and corrosion of the screens by aqueous chlorides is detrimental. Immediate drying and rescreening deagglomerates the fines and results 


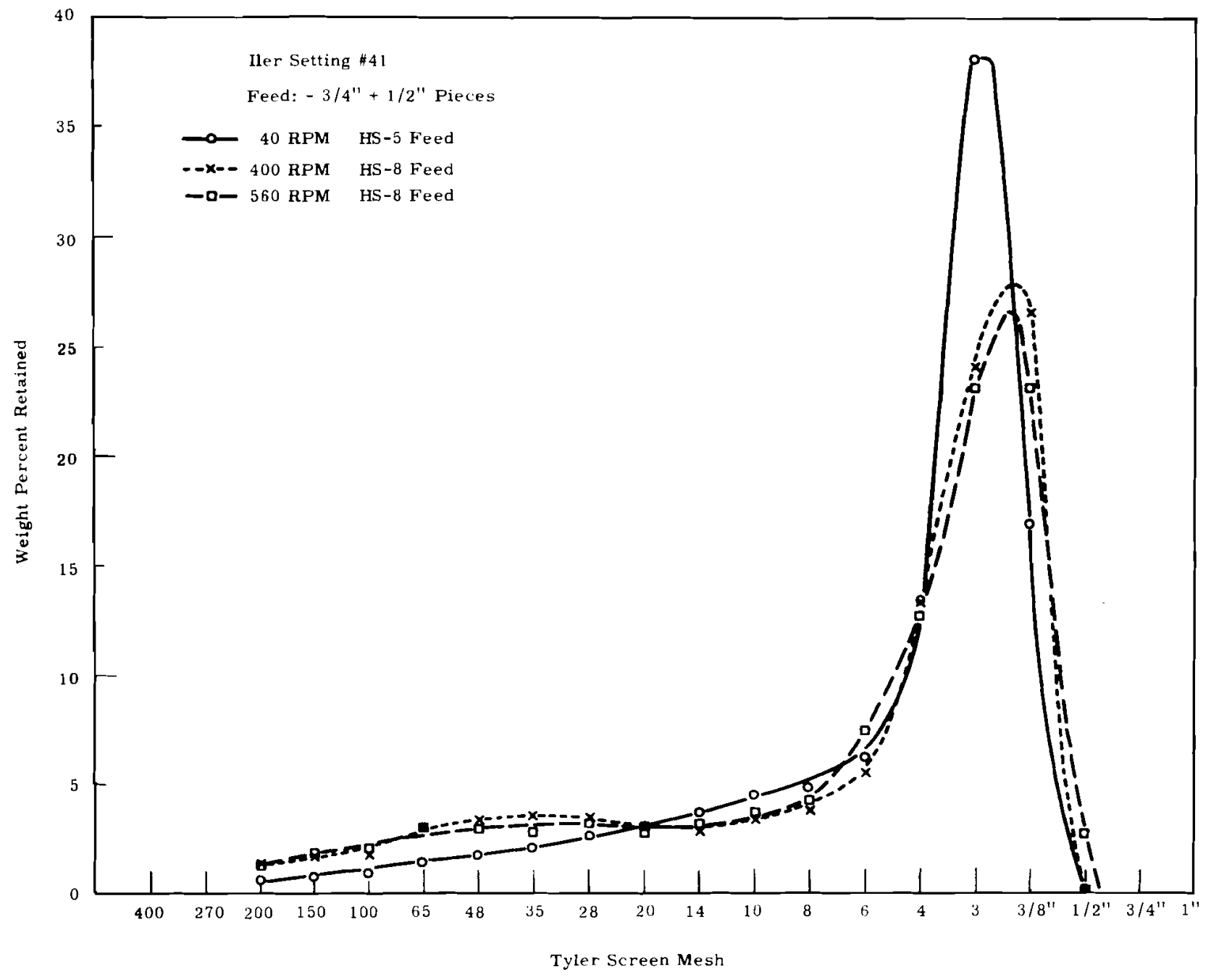

$\stackrel{\text { ก }}{\circ}$

FIGURE 50

Effect of Speed on Crushing with Iler Disc Pulverizer - Coarse Setting 


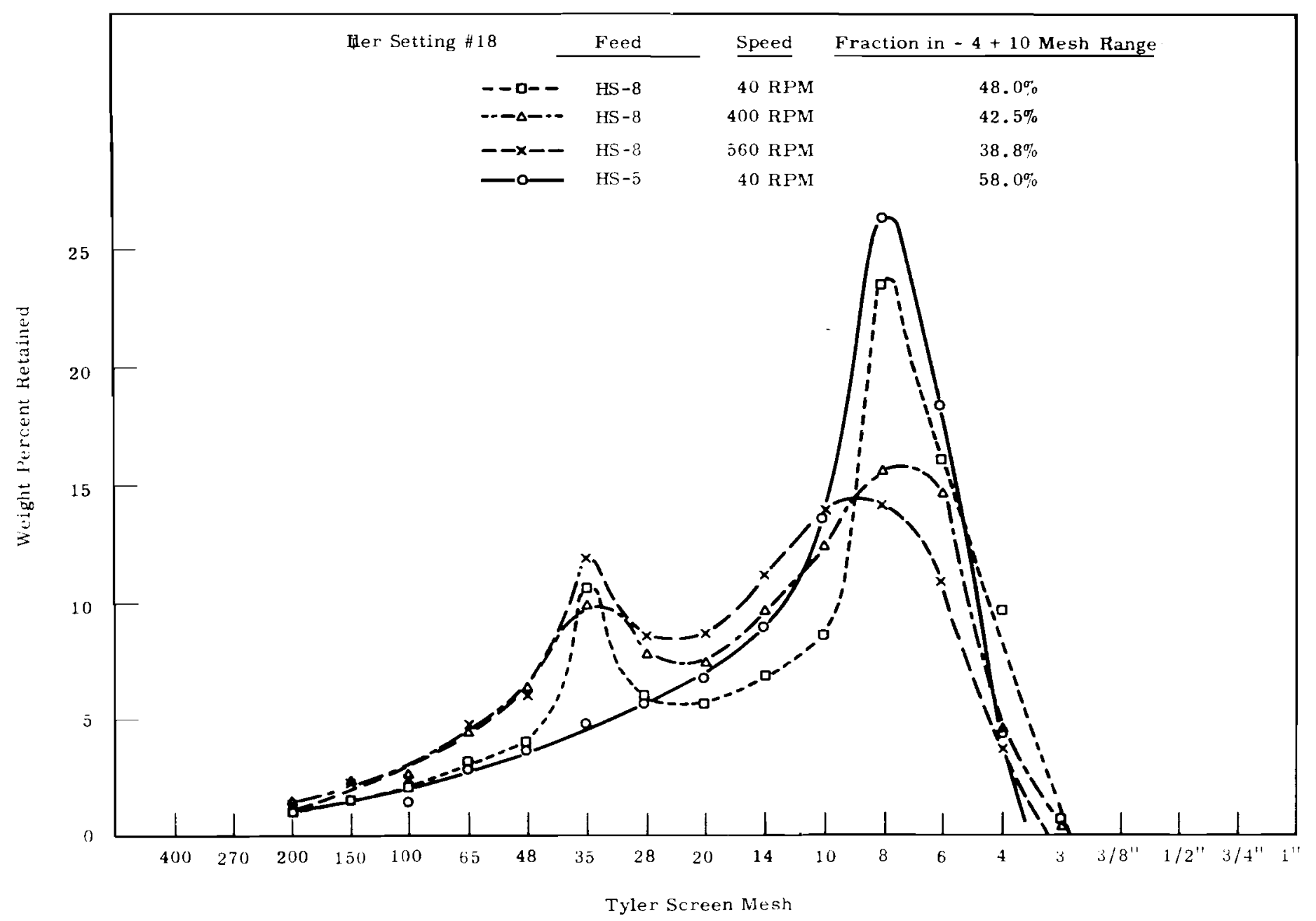

FIGURE 51

Effect of Speed on Single Pass Crushing of Electrolytic $\mathrm{UO}_{2}$ with Iler Disc Pulverizer 


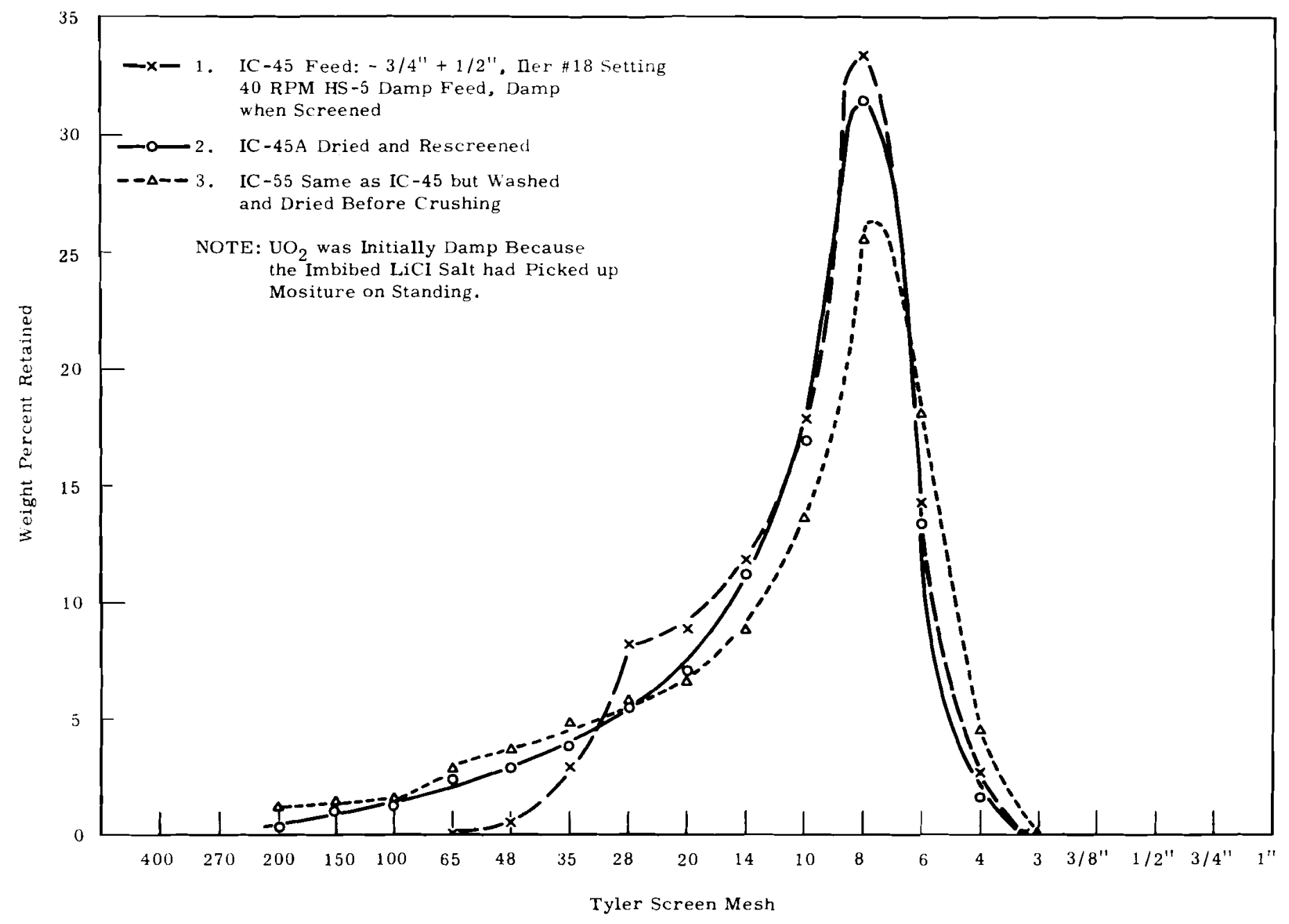

FIGURE 52

Effect of Moisture on Crushing and Screening Operations with Iler Disc Pulverizer 
in a slight lowering of the peak, which could be due to degradation of the $-6+8$ mesh particles or loosening of fines stuck to large particles. Washing and drying the product before crushing lowers the peak appreciable and produces more fines. This may be related to fracturing of large particles during drying, or greater particle degradation during dry crushing。

The results of crushing the $\mathrm{UO}_{2}$ in several size reduction steps are shown in Figure 53. The significant conditions for these runs are HS-8 feed and $557 \mathrm{rpm}$, which should be compared with the single Run 1C-17 in Figure 51, which produced 38.8\% $-4+10$ mesh product. Decreasing the feed-to-product size-reduction ratio per step and using only the +4 mesh material as feed for the next step produced a combined product containing $49.7 \%-4+10$ mesh, which is far greater than any single stage crushing operation could produce with this feed material and crusher speed.

Press Crushing with Notched Blades

Earlier experiments with a Carver* hydraulic press had shown that the $\mathrm{UO}_{2}$ could be split off pyrolytic graphite electrodes by a single V-shaped blade (Figure 37, page 94). Since the hot cell demonstration would require only a very low capacity crushing apparatus and the development of multipurpose equipment was desirable because of space considerations, size reduction by pressing was studied. The test apparatus is shown in Figure 54 。 The pressures reported are those read on the press gauge, so that they must be related to the area of contact, which was about $10 \mathrm{in}^{2}{ }^{2}$, to indicate the crushing force directly。

Cutting the large as-deposited $\mathrm{UO}_{2}$ chunks into 1/2-in。 cubes with a single blade 5/8-ino-deep x 5/8-ino-wide triangular cross section was accomplished with very little fines formation as shown in Figure 55。 This was made easier because deposits are usually about 1/2-in. thick so that only cutting along the crystal boundaries is required. Three 5/8-in。 blades produced the same distribution when operated without overloading. Crushing of large pieces of $\mathrm{UO}_{2}$ with three parallel blades at 5/16-in。 spacing produced a size distribution peak at $-3 / 8-i n ;+3$ mesh, but appreciable fines were produced。 Use of 5/32-in. blades produced a peak in the desired $-4+10$ mesh range but

*

Fred S。 Carver, Inc., Summit, New Jersey。 


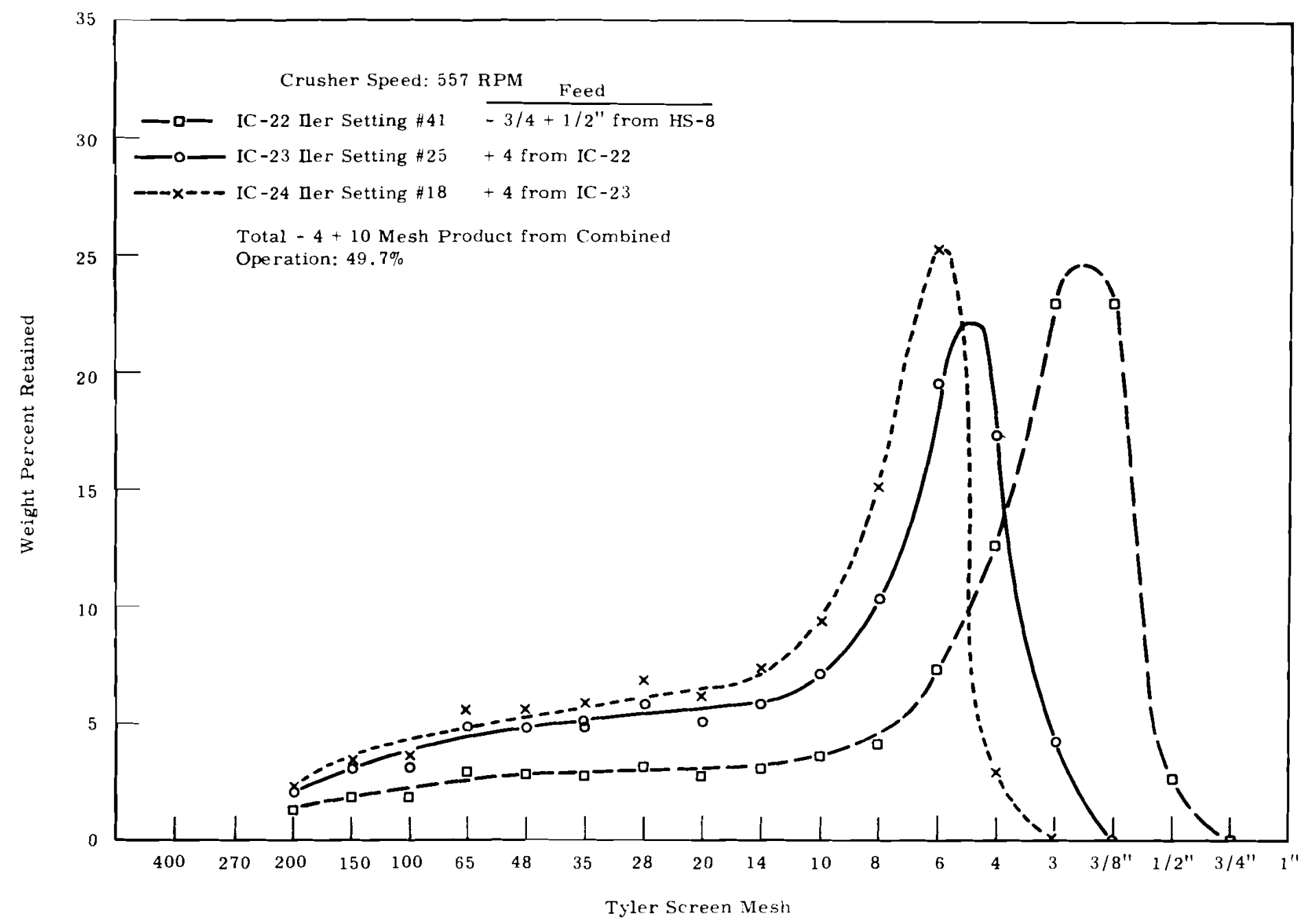

FIGURE 53

Integrated Crushing of Electrolytic $\mathrm{UO}_{2}$ with Iler Disc Pulverizer to Produce Large Size Fraction 


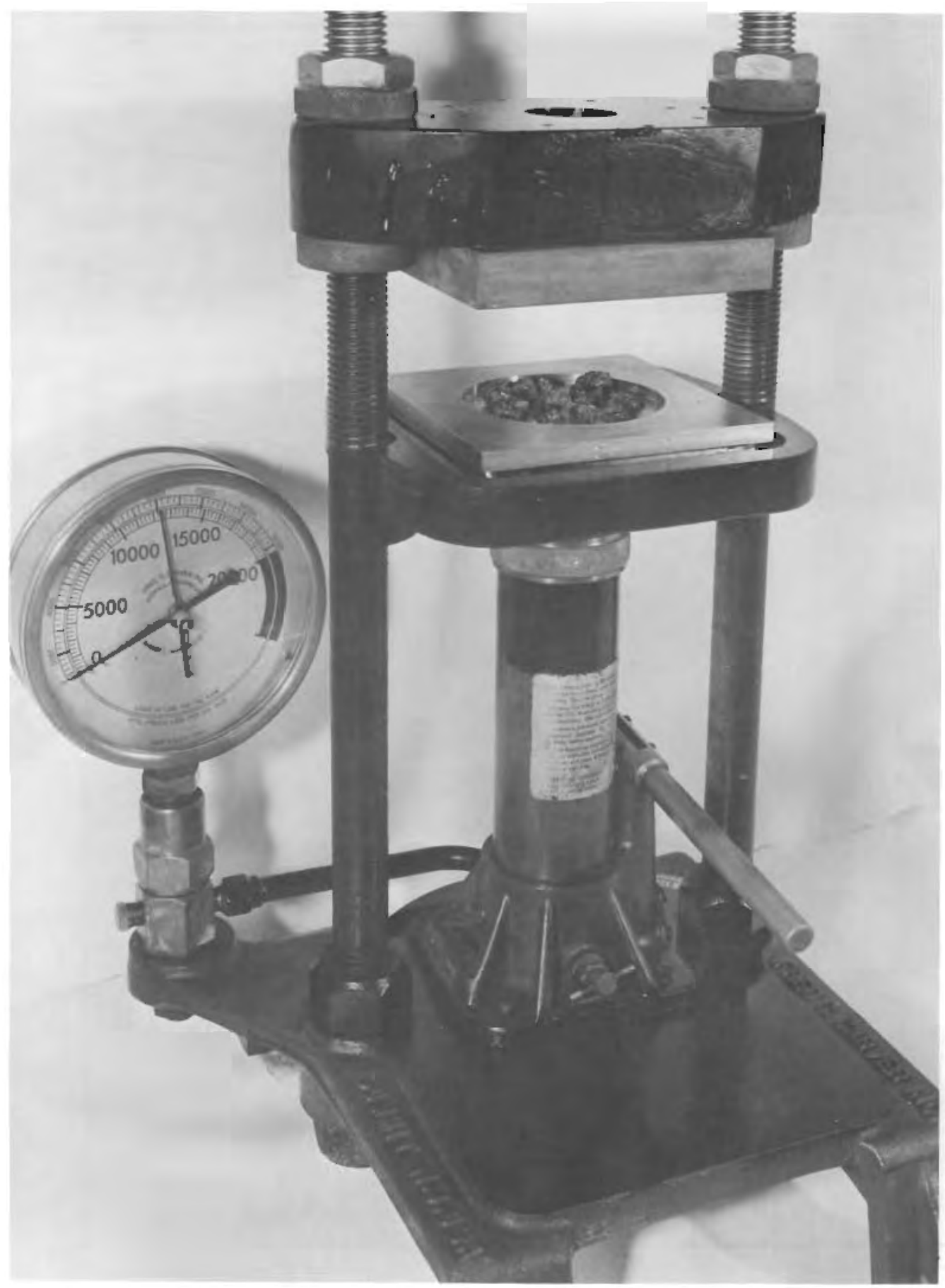

FIGURE 54

Press for Dicing and Parallel Plate Crushing Tests 


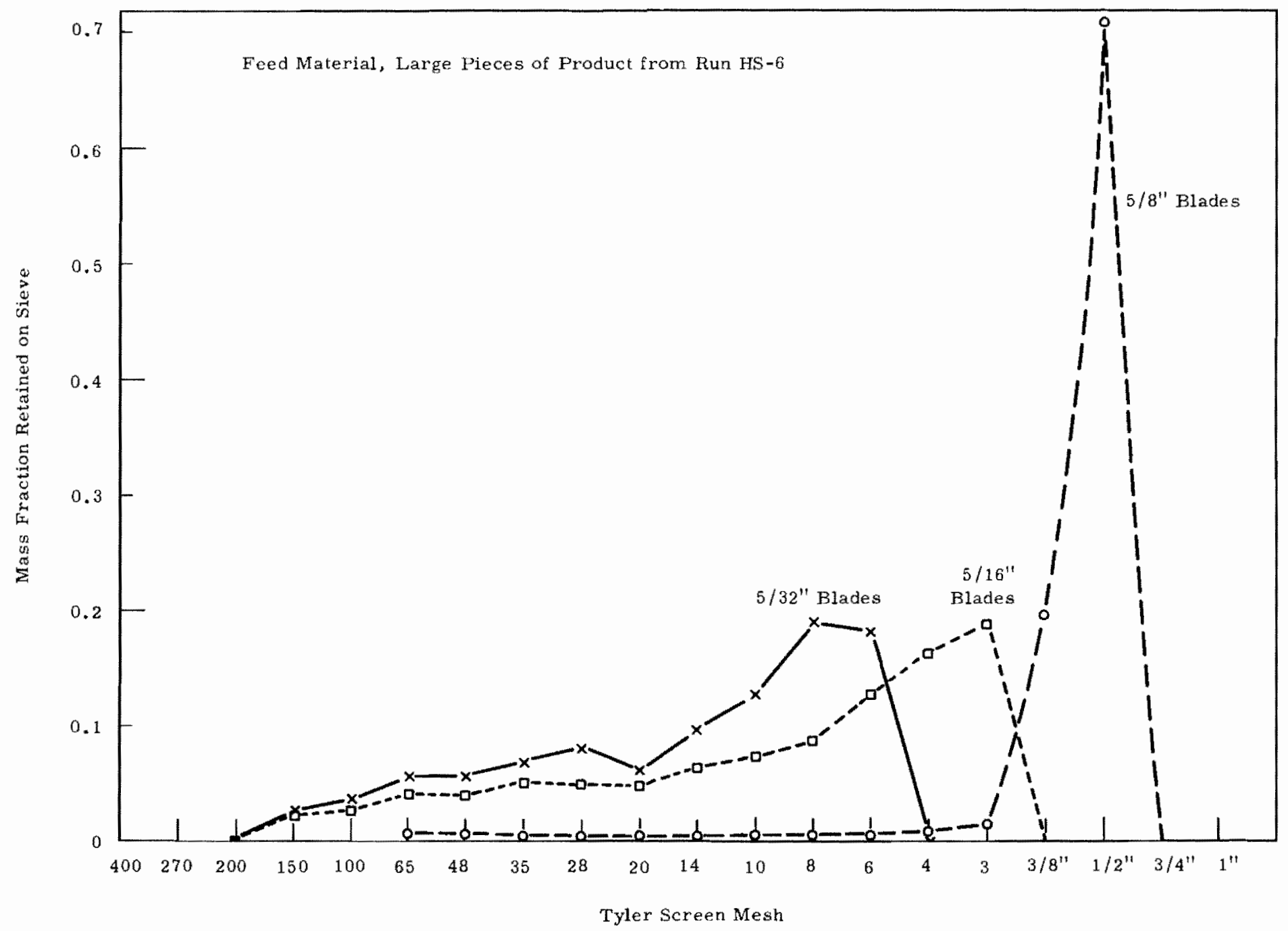

FIGURE 55

Product from $\mathrm{UO}_{2}$ Dicer Operation at 500 psi Terminal Pressure 
even more fines were produced, probably because the pieces were always crushed a little after the blades had split them since no dimension of the original piece was less than the blade depth。

In'Figure 56 is shown the effect of pressure on an integrated dicing operation. The +4 mesh material from each test was used as feed for the next smaller set of blades. Lowering the gauge pressure from 500 psi to 200 psi increased the desired $-4+10$ mesh fraction from 50 to $53 \%$ and decreased the -65 mesh fines threefold from $7.2 \%$ to $2.8 \%$. A check on the reproducibility of tandem dicing operations gave little variation in duplicated operations.

In Figure 57 the contributions of the products from each blade size in a tandem series of 4 dicings are shown. The 5/16 in。 and the 5/32 in. blade dicing steps produced 35.0 and $33.8 \%$, respectively, of their products in the $-4+10$ mesh range compared with $21,8 \%$ in the single step dicing shown with $5 / 16$ in. blades in Figure 55. The total percentage of $-4+10$ mesh in the composite product was $56.2 \%$, quite close to the goal of $60 \%$, but the intermediate $-35+65$ mesh fraction was only $12.0 \%$, far less than the desired $20 \%$.

\section{Parallel Plate Crushing}

Although dicing was found to be feasible for producing the largest particle size fraction, it could not produce the required quantity of the $-35+65$ mesh fraction。 Roll crushing appeared to be a reasonable alternative not only for the intermediate fraction but also for the large size fraction after initial dicing to $-3 / 4$ in。 $+1 / 2$ in。 chunks had been accomplished。 Because the space limitations required multipurpose equipment, the hydraulic press with parallel plates was tested as a substitute for roll crushing. In view of the beneficial effect of speed reduction on the Iler disc pulverizer performance, parallel plate crushing considered as zero speed roll crushing appeared attractive。

In parallel plate crushing the bottom plate is recessed to eliminate indexing the plate spacing by controlling the throw of the hydraulic power supply. The recess is filled with particles to be crushed and the desired pressure is exerted by the press. Figure 58 shows two important factors influencing the product particle size distribution ratio. Increasing the step 


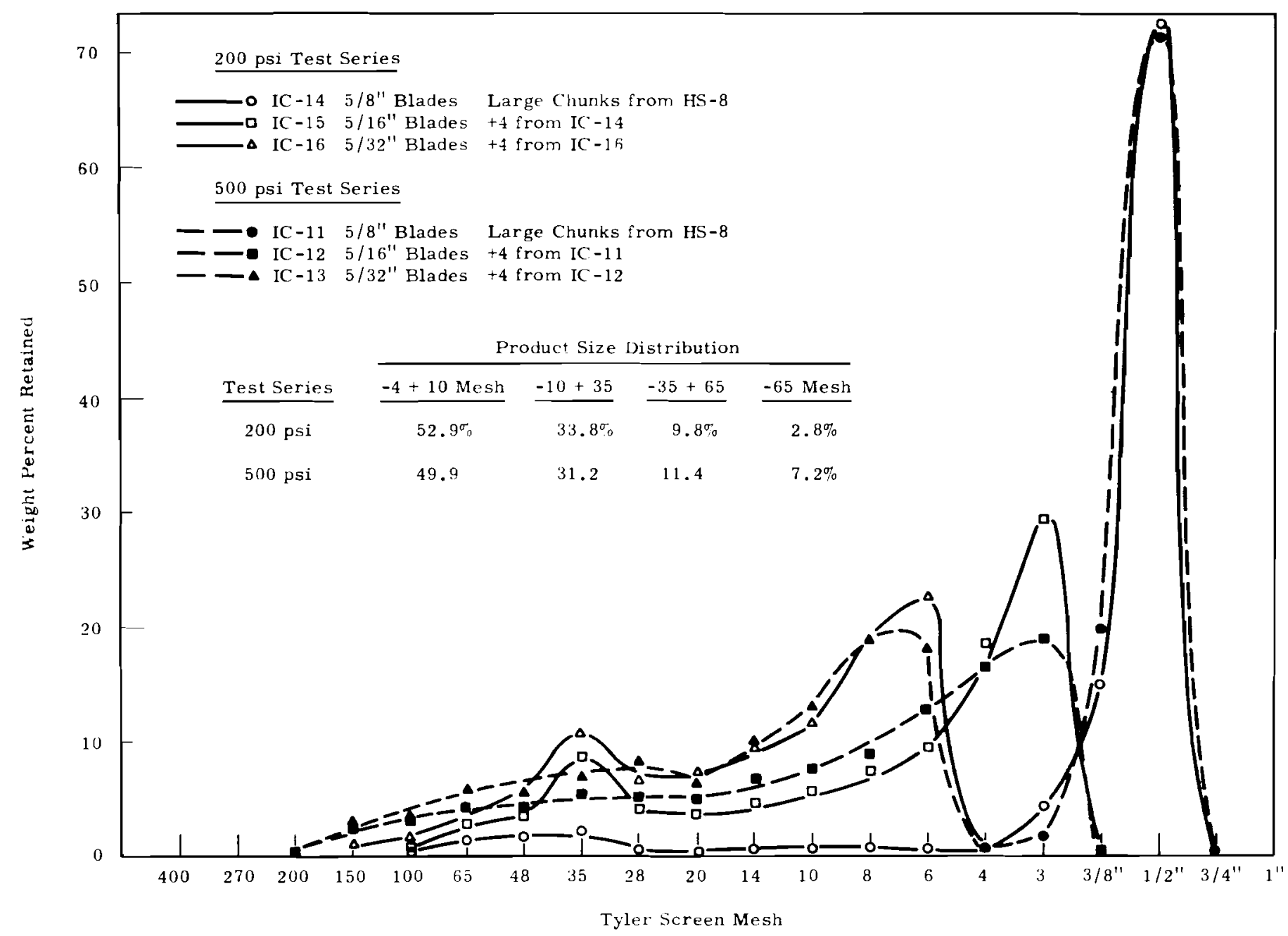

FIGURE 56

Effect of Pressure on Dicing of Electrolytic $\mathrm{UO}_{2}$ 


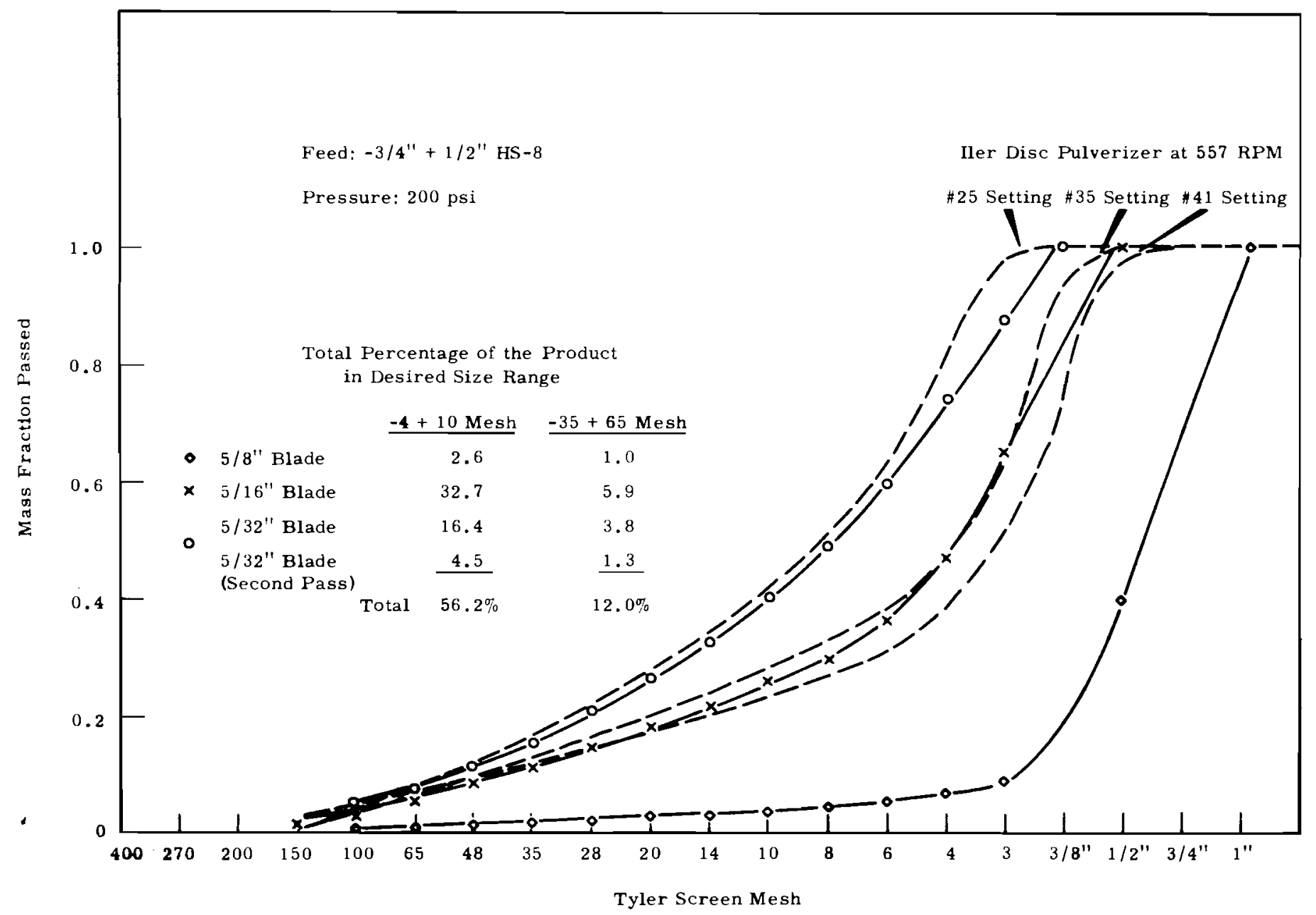

FIGURE 57

Production of Large and Intermediate Size Particles by Integrated Dicing Operations Comparison of Size Distribution with Iler Disc Pulverizer Product 


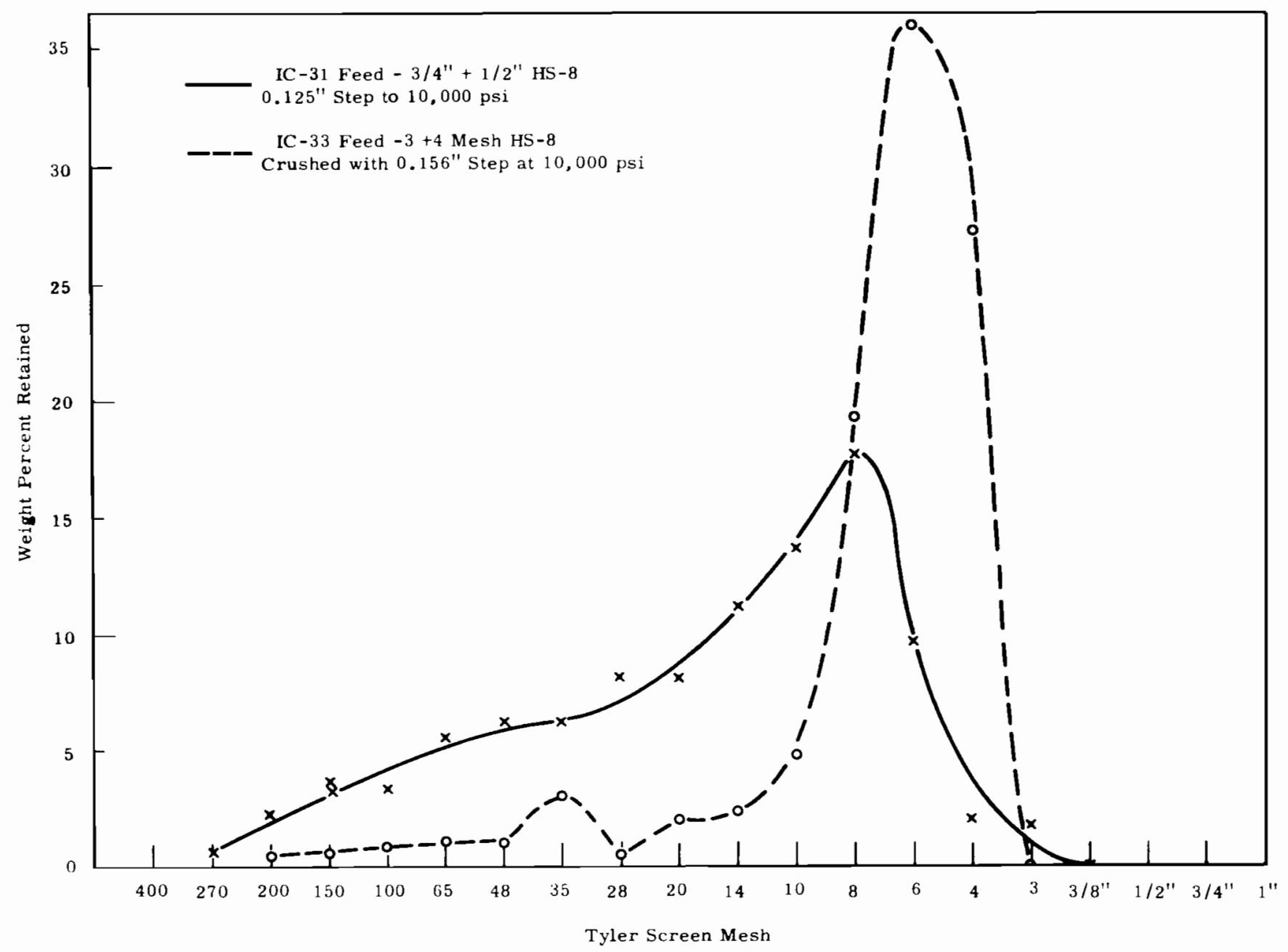

FIGURE 58

Single Pass Crushing with Parallel Plates Effect of Step Size and Size Reduction 
size from 0.125 in. to 0.156 in. increases tile product particle size by a factor of 1.5. At the same time, increasing the size of the feed spreads the distribution of the product particles and produces more fines. A gauge pressure of 10,000 psi or greater was used in all parallel plate crushing runs.

The effect of batch size upon the particle size distribution is shown in Figure 59. If a single particle were crushed there would be no interaction between particles and a minimum of fines is produced. The effect of doubling and redoubling the batch size is to decrease the peak height, to shift it slightly to lower particle size, and to increase the quantity of fines. The middle batch size of 57 g per crushing pass was used in most parallel plate crushing studies。

The last stage in the procedure for optimizing the step sizes to be used in tandem crushing with parallel plates is shown in Figure 60. In this stage the $0.156 \mathrm{in}$. step is selected over the $0.222 \mathrm{in}$. step as the fourth part of a five part series to produce a $-4+10$ mesh particle. The 0.156 in. step shows an increase in the large size fraction from 56.4\% to $63.4 \%$ and with a corresponding reduction in the -65 mesh fines.

The next problem was to develop a method for converting as much as possible of $-10+35$ mesh fraction to $-35+65$ mesh. As show in Figure 61, both 0.016 in. steps and 0.012 in. steps were tried with 10,000 psi pressure but the resulting peak was at too large a particle size. A higher pressure of $16,000 \mathrm{psi}$ and no step gave the highest fraction, 43.7\% in the desired range. The Iler Disc Pulverizer is also capable of producing a product in the desired range. At the optimum setting of 3.5 , about $48 \%$ of the product is in the $-35+65$ mesh range。

The final treatment scheme selected for use in the Salt Cycle demonstration is shown in Figure 62. As employed here it produced 57.5\% $-4+10$ particles, $19.7 \%-35+46$ mesh particles and all other fractions were pulverized to -200 mesh by ball milling.

Multipurpose Fines Production, Sieving, and Blending Equipment

Because of space limitations in the Salt Cycle demonstration, development of a single, multipurpose apparatus for producing minus 200 mesh fines, sieving 


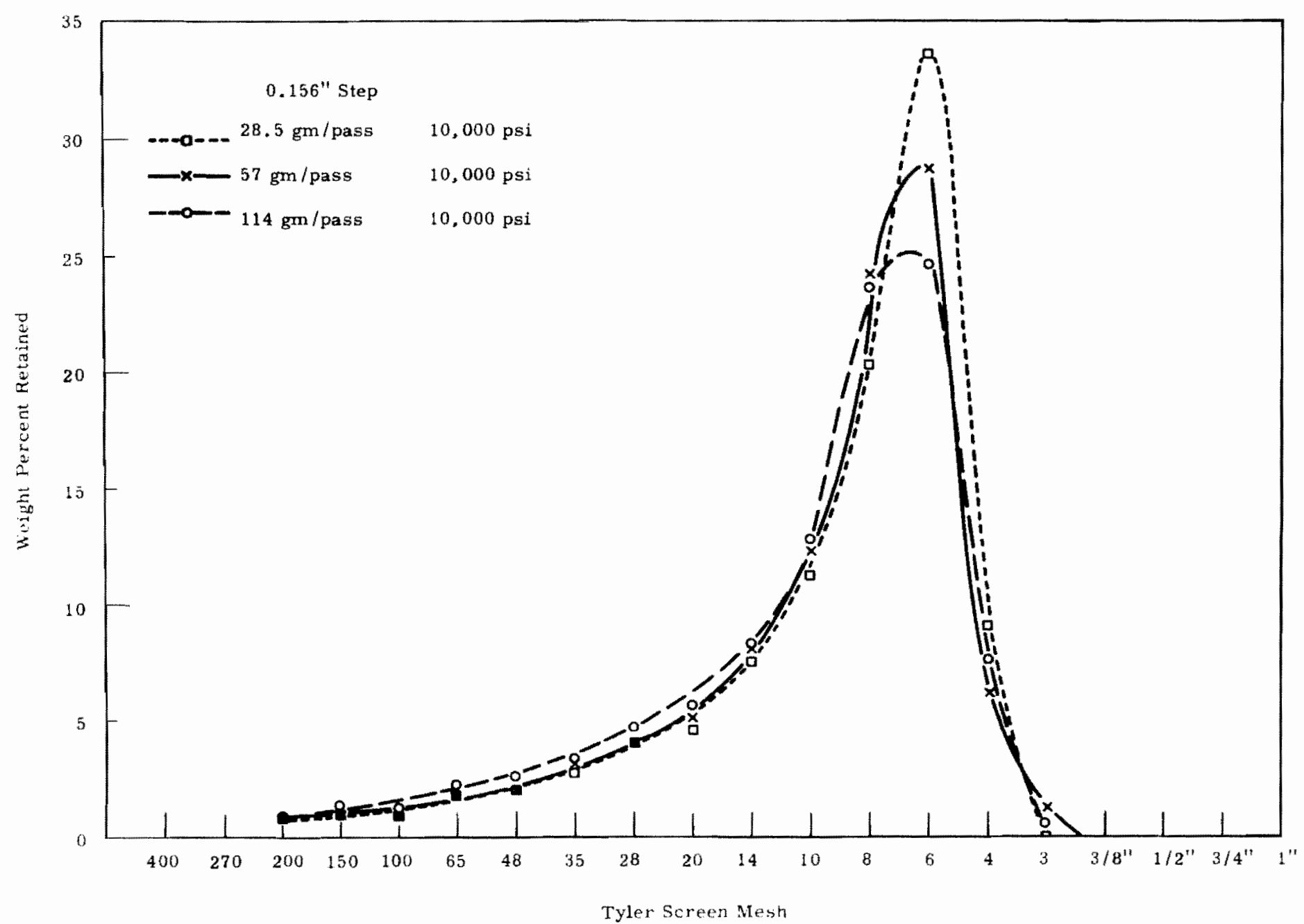

FIGURE 59

Effect of Batch Size on Parallel Plate Crushing 

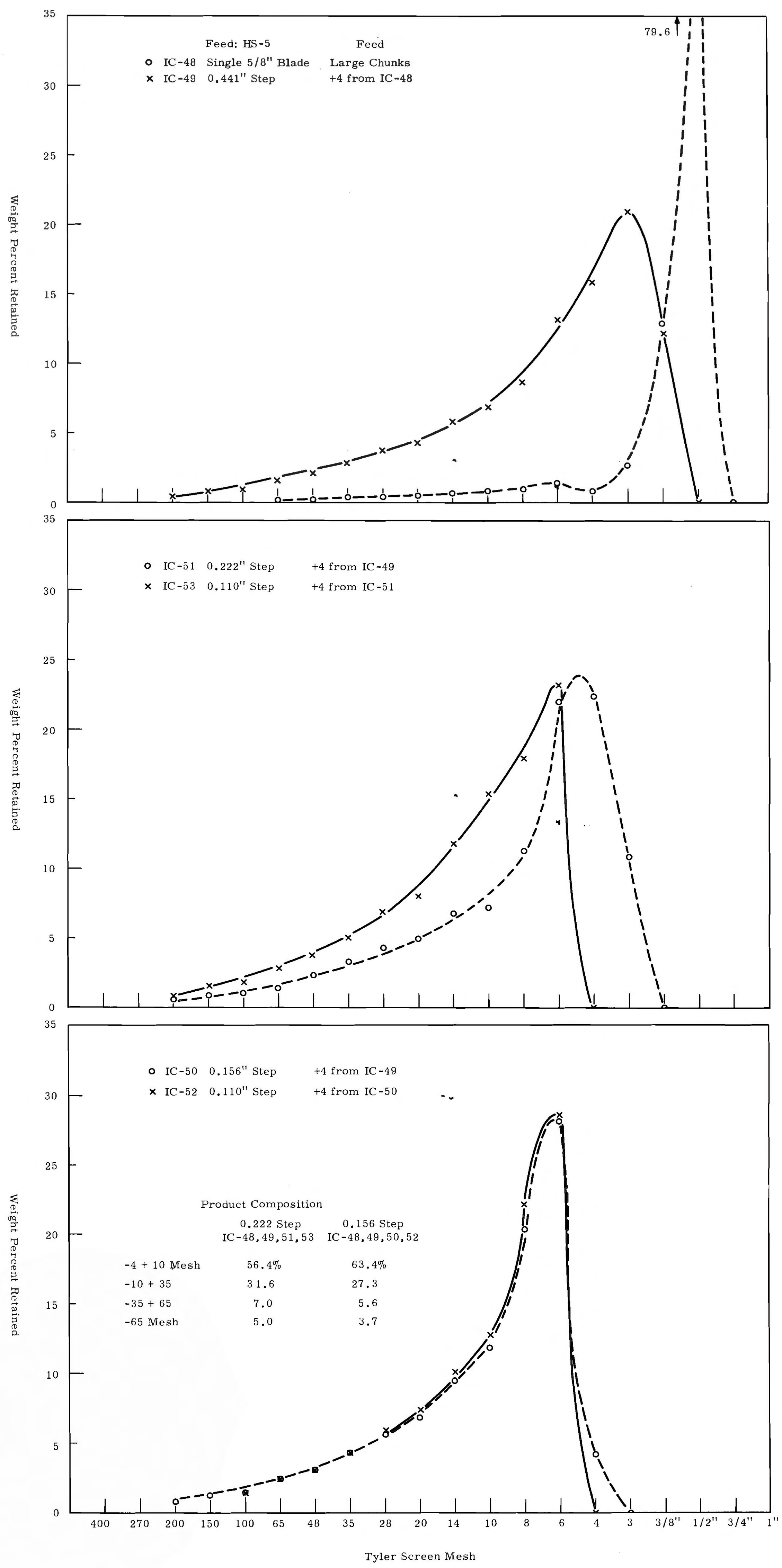


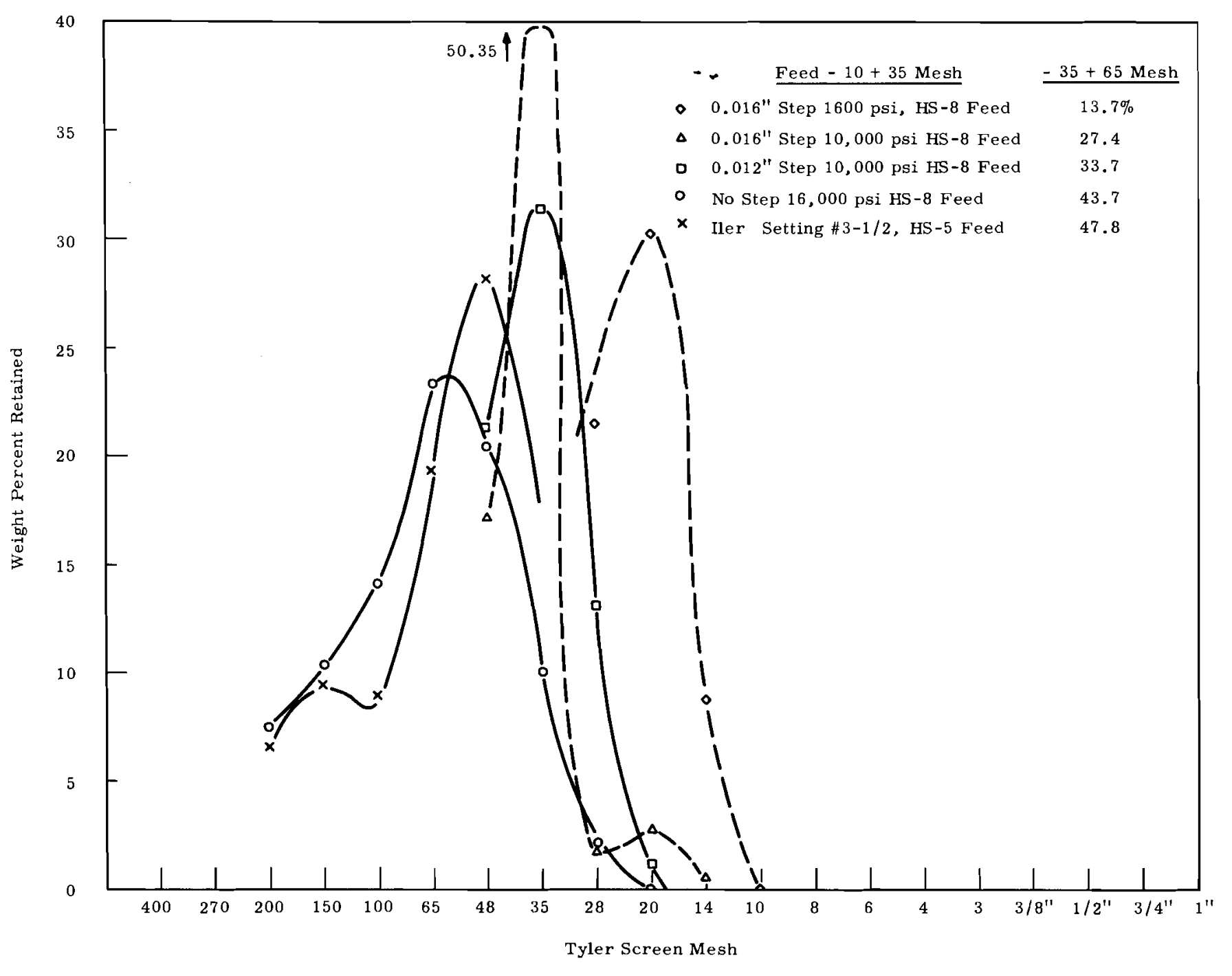

FIGURE 61

Effect of Pressure on Production of Intermediate Fraction $\mathrm{UO}_{2}$ Particles 


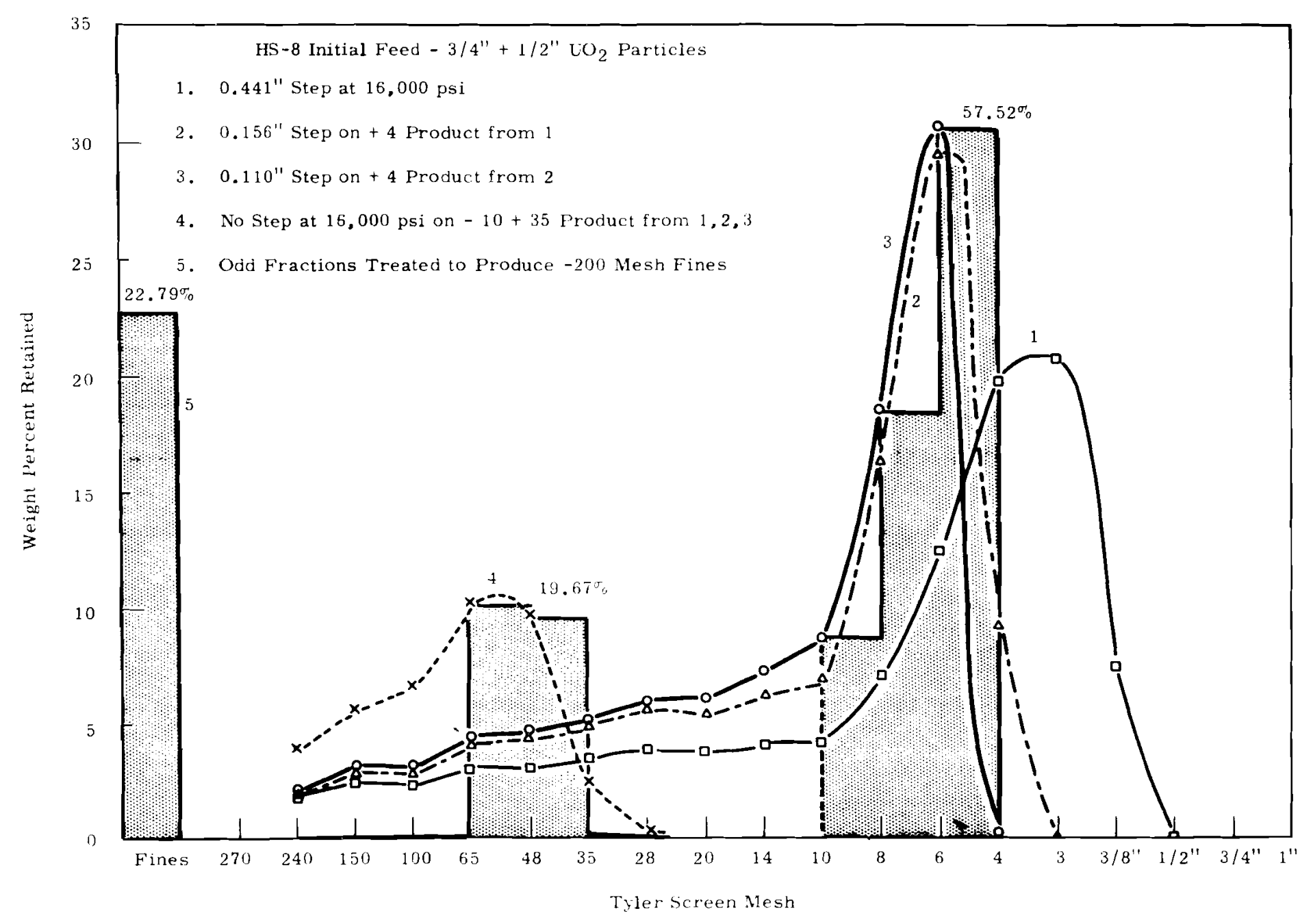

FIGURE 62

Preparation of $\mathrm{UO}_{2}$ Feed for Vibratory Compaction by Parallel Plate Crushing 
the product from the parallel plate crushing operation, and blending the three size fractions was attempted. A Model 30 Red Devil Paint Conditioner* with a figure eight oscillatory motion was modified to allow variable speed. The electrolytic $\mathrm{UO}_{2}$ was placed in a heavy-walled 3-in。-diam by 4-in.-long steel can containing steel or alumina balls and shaken at high speed. The impact of the balls shatters the large pieces of $\mathrm{UO}_{2}$ and further size reduction by impact and grinding occurs. The results are shown in Table XIX。 The amount of -100 mesh material formed is relatively independent of initial particle size and is a strong function of container and batch size, and apparently the process of pulverization to minus 200 mesh fines does not go to completion in shaking times of 1 to $2 \mathrm{hr}$. Reducing the shaking speed from 1315 shakes/min to 940 shakes/min produces a sharp decrease in the rate of shattering of the largest particles, and even a much longer operating time does not carry the process to completion. Comparison of Runs SH-7 and PS-5 shows that using alumina balls, which are much lighter than the steel balls, has little effect on the process of size reduction. Shaker speed has the most significant effect on the process of size reduction. Doubling the speed of the shaker has a dramatic effect on the rate of fines production, producing $94 \%-200$ mesh fines in $30 \mathrm{~min}$. Further size reduction work with this equipment was delayed indefinitely until a higher speed system could be devised。

To demonstrate the second phase of its multipurpose capabilities, the paint conditioner was used to screen $\mathrm{UO}_{2}$ on three 3-in。-diam sieves。 As shown in Table XX, 200 shakes/min appeared to be an optimum speed for sieving。 In Run SH-1 100 shakes/min was inadequate to pass the $\mathrm{UO}_{2}$ through the $10 \mathrm{mesh}$ screen, while 400 shakes/min degraded some of the +10 mesh particles. Confirmation that 200 shakes/min did not degrade the particles appreciably is found in the comparison with the screen fractions obtained by a standard screen analysis of the feed. Reducing the shaking time from 15 min to 10 min produces no significant change in the screen fractions, indicating that sieving was complete at $10 \mathrm{~min}$ and that particle degradation had not occurred at $15 \mathrm{~min}$ 。

* Red Devil Tools, Union, New Jersey 
TABLE XIX

\section{FINES PRODUCTION BY HIGH-SPEED IMPACTION}

Equipment: Model No. 30 Red Devil Paint Conditioner modified for variable speed. Heavy walled

3 in. diam $x 4$ in. length cylindrical steel can with ( 3 to 6 ) $3 / 4$ in. diam steel balls.

\begin{tabular}{|c|c|c|c|c|c|c|c|c|c|}
\hline Run No. & $\begin{array}{c}\text { Speed, } \\
\text { Shakes/min } \\
\end{array}$ & $\begin{array}{l}\text { Shaking } \\
\text { Time, min }\end{array}$ & \multicolumn{2}{|c|}{ Feed Material } & \multicolumn{4}{|c|}{$\frac{\text { Product Size Distribution, percent }}{+100 \text { mesh }-100+200-200 \text { fines }}$} & Comments \\
\hline PS-2 & 1315 & 30 & $-3 / 4$ in. $+1 / 2$ in. & HS-5 deposit & 48.5 & & 19.1 & 32.3 & \\
\hline PS-3 & 1315 & 60 & $-3 / 4$ in. $+1 / 2$ in. & HS-6 & 35.0 & & 24.8 & 40.2 & \\
\hline PS-8 & 940 & 345 & $-3 / 4$ in. $+1 / 2$ in. & HS-7 & 26.4 & & 22.7 & 50.9 & \\
\hline PS-7 & 940 & 345 & $-3 / 4$. in. $+1 / 2$ in. & HS-7 & 22.0 & & 16.3 & 61.7 & +3 mesh $=18.1 \%$ \\
\hline PS -4 & 1315 & 30 & $-10+35$ mesh & HS-6 & 38.4 & & 25.7 & 35.8 & $\begin{array}{l}\text { (small can, } 1 / 6 \text { batch } \\
\text { size) }\end{array}$ \\
\hline PS -5 & 1315 & 30 & $-10+35$ & HS-6 & 51.8 & & 18.2 & 29.8 & v \\
\hline PS-6 & 1315 & 100 & $-10+35$ & HS-6 & 30.2 & & 22.4 & 47.3 & \\
\hline & & & & & $-10+35$ & $-35+65$ & $-65+200$ & & \\
\hline $\mathrm{SH}-7$ & 1315 & 27 & $-10+35$ & $\mathrm{HS}-7$ & 35.1 & 23.5 & 15.9 & 38.3 & $3 / 4$ in. Alumina balls \\
\hline $\mathrm{SH}-8$ & 2420 & 30 & $-10+35$ & HS-7 & 0.4 & 0.07 & 4.8 & 94.1 & Alumina balls \\
\hline
\end{tabular}




\section{TABLE XX}

\section{SIEVING STUDIES IN MULTIPURPOSE EQUIPMENT}

Equipment: Model No. 30 Red Devil Paint Conditioner modified for variable speed. 3 in. diam X 5/8 in. depth sieves - Batch Size 500-1000 grams $\mathrm{UO}_{2}$.

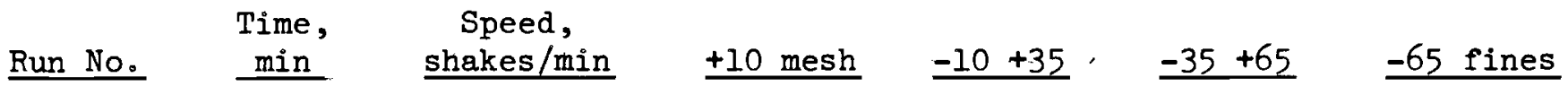

Feed Material: HS-5 Deposit, from Iler Disc Pulverizer Crusher Run, uncharacterized, same feed for each run.

$\begin{array}{rrrrrrr}\mathrm{SH}-1 & 15 & 100 & 83.1 & 5.8 & 5.2 & 5.8 \\ \mathrm{SH}-2 & 15 & 200 & 21.2 & 15.7 & 13.4 & 46.2 \\ \mathrm{SH}-3 & 15 & 400 & 7.8 & 14.5 & 14.0 & 63.7\end{array}$

Feed Material characterized by Run SH-4

\begin{tabular}{|c|c|c|c|c|c|c|}
\hline $\mathrm{SH}-4$ & 15 & Standard Shaker & 63.4 & 12.5 & 4.4 & 19.6 \\
\hline $\mathrm{SH}-5$ & 15 & 200 & 59.7 & 13.6 & 7.1 & 19.6 \\
\hline SH-6 & 10 & 200 & 58.8 & 13.9 & 8.1 & 19.0 \\
\hline
\end{tabular}


Blending operations were not conducted with the paint conditioner, although the experiments with pulverizing and screen had encouraged the concept of using the paint shaker as a multipurpose device。

\section{Ball Milling}

The results of a series of ball milling tests conducted with electrolytic $\mathrm{UO}_{2}$ are shown in Figure 63. A two quart jar containing alumina pellets and the unwanted $-10+35$ mesh size fraction was rotated at $60 \mathrm{rpm}$ for various time intervals. The results show that about $8 \mathrm{hr}$ are required to grind $99 \%$ of the material to $-100 \mathrm{mesh}$ and $11.7 \mathrm{hr}$ are required to produce 99\% -200 mesh fines. The initial curvature in the size fraction versus time curve is due to the time lag produced in getting the +35 mesh particles ground down to the largest screen size (100 mesh)。

A remotely operable ball milling apparatus with a stainless steel jar was constructed. Since previous experience had indicated that some iron would be introduced into the product the ball mill jar was lined with Unichrome $B$, and tests were conducted to determine the amount of organic material that appeared in the $\mathrm{UO}_{2}$ product.

Ball milling of an electrolytic $\mathrm{UO}_{2}$ feed material initially containing $38 \mathrm{ppm}$ chloride for $19 \mathrm{hr}$ produced a product containing $245 \mathrm{ppm}$ chloride, which corresponds to 365 ppm polyvinyl chloride, the principal ingredient of Unichrome. Ball milling for a total of $97 \mathrm{hr}$ produced $350 \mathrm{ppm}$ chloride or 575 ppm polyvinyl chloride. Spectrometric analysis also showed the presence of several hundred ppm of oil which may have corresponded to the plasticizer in the Unichrome. This Unichrome contamination of the fines product in the Salt Cycle demonstration (7) forced a return to all steel ball mills after the first recycle fuel element had been fabricated.

\section{OFF-GAS TREATMENT}

The conventional packed column caustic scrubber used to remove chlorine and hydrogen chloride from the off-gas in the pilot plant operations is described in the equipment section of this report (page 47)。

RE. I. du Pont de Nemours and Company 


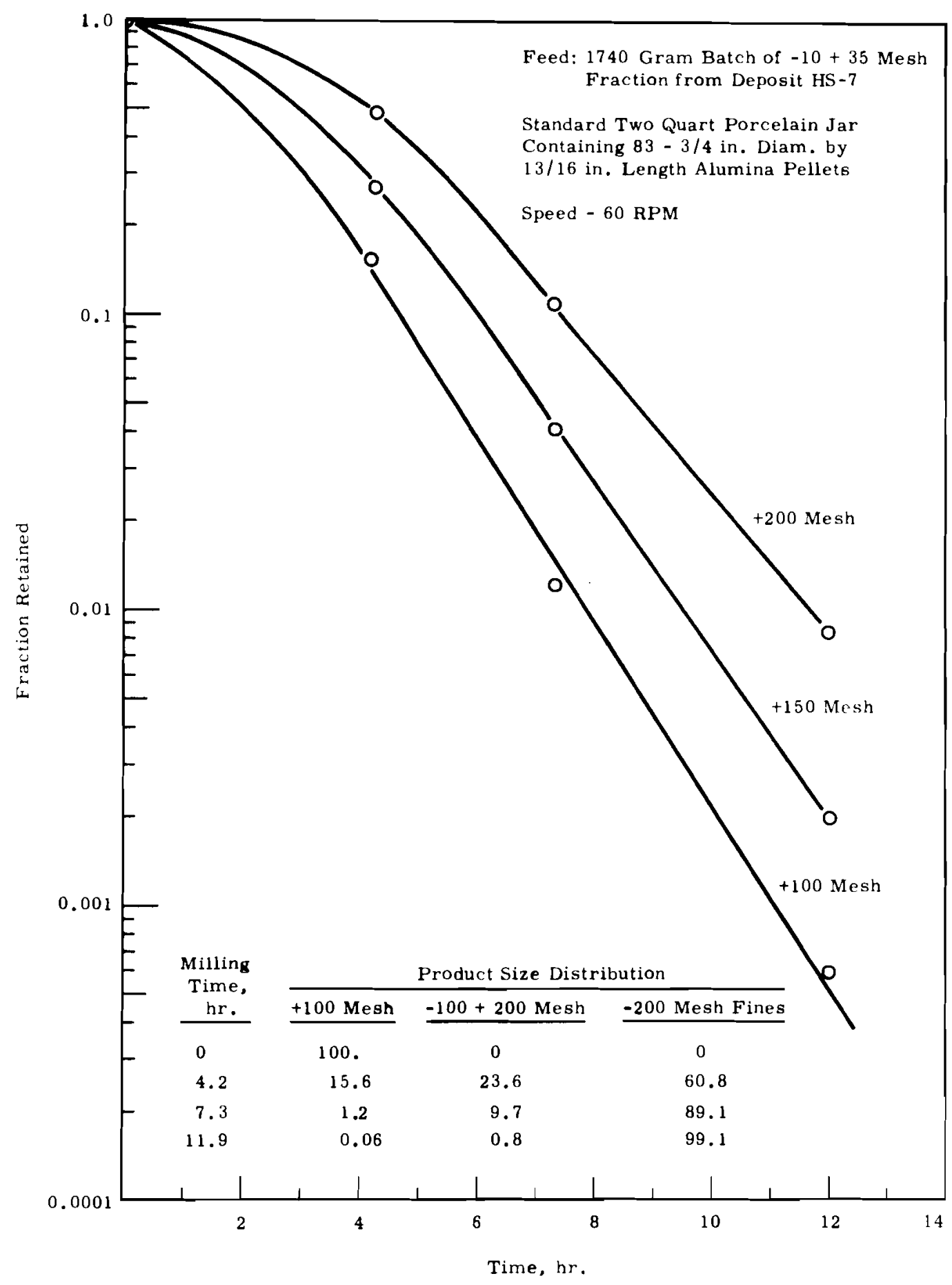

FIGURE 63

Ball Milling of Electrolytic $\mathrm{UO}_{2}$ 


\section{Calstic Scrubber for the Salt Cycle Demonstration}

The caustic scrubber for the Salt Cycle demonstration consisted of a 60 gallon reservoir surmounted by a 6-ft-high, 7-in.-diam tower packed with $5 \mathrm{ft}$ of 3/4-in. polyethylene Raschig rings and fitted at the top with a 6-in。 nickel mesh for de-entrainment. The scrubber and other auxiliary equipment such as filters and pumps are described in the report of the Salt Cycle demonstration。 (7) The caustic in the system reached $60^{\circ} \mathrm{C}$ at times because of the neutralization reaction. The reservoir was first made of Hastelloy $C$, but corrosion in the vapor space at the flange made it necessary to replace the inlet into the gas space by a submerged Teflon $(\mathbb{R}$ inlet line。 A water line had to be installed in the off-gas line to flush out the caustic that plugged the submerged inlet line periodically. Corrosion of the Hastelloy $C$ in the vapor space eventually caused a leak and the reservoir was replaced by a polyvinyl chloride tank that held up well under the combined peroxide caustic, hypochlorite, chlorine, and hydrogen chloride atmosphere.

Hypochlorite Destruction

Chlorine reacts with caustic to produce hypochlorite in the following reaction。

$$
\mathrm{Cl}_{2}+2 \mathrm{NaOH}=\mathrm{NaCl}+\mathrm{NaOCl}+\mathrm{H}_{2} \mathrm{O}
$$

The auxiliary tanks in which spent caustic was stored in the Salt Cycle demonstration were made of stainless steel, which is corroded by hypochlorite。 Therefore, the hypochlorite had to be destroyed before it left the caustic scrubber。 The 15 wt\% $\mathrm{NaOH}$ solution was first treated with ammonia and later urea to destroy the hypochlorite by the following reactions:

$$
\begin{aligned}
& 2 \mathrm{NH}_{3}+3 \mathrm{NaOCl} \rightarrow 3 \mathrm{NaCl}+3 \mathrm{H}_{2} \mathrm{O}+\mathrm{N}_{2} \\
& \left(\mathrm{NH}_{2}\right)_{2} \mathrm{CO}+3 \mathrm{NaOCl}+2 \mathrm{NaOH} \rightarrow 3 \mathrm{NaCl}+\mathrm{Na}_{2} \mathrm{CO}_{3}+3 \mathrm{H}_{2} \mathrm{O}+\mathrm{N}_{2}
\end{aligned}
$$

The hydrolysis of urea in the $\mathrm{NaOH}$ solution resulted in the ultimate formation of a sub-micron mist of $\mathrm{NH}_{4} \mathrm{Cl}$ which plugged the tower off-gas lines, leading to the abandonment of the second method. Similar behavior was obtained with ammonia。

(R) $E, I$ du Pont de Nemours and Company。 
The reaction of hydrogen peroxide with hypochlorite:

$$
\mathrm{H}_{2} \mathrm{O}_{2}+\mathrm{NaOCl}+\mathrm{H}_{2} \mathrm{O}+\mathrm{O}_{2}
$$

achieved complete destruction of the hypochlorite without adverse side effects. A $10 \%$ excess of $15 \mathrm{wt} \% \mathrm{H}_{2} \mathrm{O}_{2}$ was added at hourly intervals. The evolution of oxygen was not a serious problem at this addition rate, although appreciable foaming occurred when a large batch of peroxide was added to a caustic solution containing a high concentration of hypochlorite. The addition of the $15 \mathrm{wt} \% \mathrm{H}_{2} \mathrm{O}_{2}$ increased the volume in the recirculating tank at a rate of 1.25 liters/hr. An estimate of the evaporation rate from the tank indicates a loss at the rate of 0.75 liters/hr. This resulted in a volume increase of 9 gal during a dissolution run, while at least 12 gal freeboard existed in the scrubber。

\section{Chlorine Recovery by Liquefaction}

Because of the large volumes of waste caustic-chloride solutions produced by the scrubber, a study of the recovery of chlorine from the off-gas by liquefaction was made in the pilot plant. The details of this study and of the removal of radioiodine from the off-gas by liquefied chlorine are reported separately。 (36) The tests showed that liquefaction of chlorine at $-100{ }^{\circ} \mathrm{C}$ from the off-gas could recover nearly all the chlorine if noncondensible gas inleakage to the salt pot is minimized, could reduce scrubber caustic requirements by a factor of ten, and could produce high iodine decontamination factors by the formation of iodine trichloride in the cold trap. 


\section{ACKNOWLEDGMENTS}

This work was performed under the guidance of $A_{0} M_{0}$ Platt and later W. Ho Swift, Managers, Chemical Engineering Development Operation, Hanford Laboratories, General Electric Company。 During the progress of the work, this unit was transferred to Battelle-Northwest and became the Engineering Development Unit, Chemical Development Section, Chemistry Department。

The success of the experimental work in this program was largely due to the efforts of engineering technicians $D_{0} H_{0}$ Walker, $J$ 。 R。 Nance, R。 CoNiemuth, and $D_{0} H$ o Siemens, who assisted in the design and operation of experiments and in interpretation of the results。

Our thanks also go to the rotational technical graduates, $J$ o $R_{0}$ Morrissey, D。 $C$ 。 Brandt, and $G$ o $R$ 。 Bloom, who conducted experiments that aided in the process development。

Much unpublished data is quoted here from the work of and from discussions with $G_{0} E_{0}$ Benedict, $J$ 。 Lo Swanson, $R, L$, Braun, $M, C$, Iambert, and $W_{0} H_{0}$ Yunker of the Chemical Separations Unit, Chemical Research Section and Wo Io Walker and $R_{0} F_{0}$ Maness of the Materials and Process Chemistry Unit, Chemical Development Section.

The authors are indebted to $D$ 。 W. Brite. I。 $P_{0}$ Murphy, and others of the Ceramics Fuel Development Operation, General Electric Company, whose evaluations of our product are reported elsewhere, $(37,38,39,40)$ 


\section{REFERENCES}

1. R。 W。 McKee。 Economic Evaluation of Close-Coupled Fuel Processing with Plutonium Recycle, BNWL-28. January, 1965.

2. A。 R。 Gibson and L。 L。 Wassell。 Extraction of Uranium and Uranium Dioxide from an Australian Ore Concentrate by a Chloride Route, AERE Rept. M/R 2513. 1958.

3. PoW。Smith。 Preliminary Cost Estimate for the Electrolytic Conversion of Uranium Oxide to Reactor Grade Uranium Dioxide, HW-73333。 April 11, 1962。

4. Wo R. Bond。 A Preliminary Economic Study of the Preparation of Reactor Grade PuO $2-\mathrm{UO}_{2}$ by the Salt Cycle Process, HW-83984。 September 9, 1964。

5. G。 E。 Benedict and $R_{0} A_{0}$ Nixon。 Hanford Salt Cycle Process I。 Plutonium Chemistry, HW-SA-3622。 General Electric Company, Richland, Washington。 July 17, 1964 。

6. G, E。 Benedict, $L 。 G$ o Morgan, and $R \circ A_{0}$ Nixon。 Plutonium Chemistry of the Salt Cycle Process, in preparation December, 1966. Pacific Northwest Laboratory, Richland, Washington。

7. Wo R. Bond, Go Jansen, $\mathrm{Jr}_{0}$, and Lo $\mathrm{K}_{0}$ Mudge, Demonstration of the Salt Cycle Process in a High Level Radiochemical Facility, BNWL-355。 December, 1966.

8. J。E。 Bodine, $J \circ$ Guon and R。 J。Sullivan, Second-Cycle Airox Reprocessing and Pellet Refabricating of Highly Irradiated Uranium Dioxide, NAA-SR-11375。 August 31, 1965。

9. J。 L。 Swanson, G。 E。 Benedict, R。 Co Smith and $G_{0} R_{0}$ Horn。 Demonstration of an Irradiated UO Fuel Cycle: First Recycle, HW-69027。 September, 1961。

10. Fo M。 Vander Wall, II。 $T$, Hahn, and Do I, Bauer, Salt-Phase Chlorination of Reactor Fuels II ARCO Process Definition and Scoping Studies, IDO-14525. October 28, 1960 ,

11. J. J. Reilly, Status Report, Reprocessing of Reactor Fuels by Volatilization Through the Use of Inert Fluidized Beds, BVL-663, May, 1961,

(Classified) (See Reference 12)

12. "Research and Development on Nonaqueous Processing," Reactor Fuel Processing Quarterly, vol 4, no. 4, pp 33-34。 Argonne National Laboratory。 vetober, 1961。

13. "Research and Development on Fuel Processing," Reactor Fuel Processing Quarterly, vol 3 no. 4, p 34。 Argonne National Laboratory, October, 1960。

14. Wo R。 Bond, Go Jansen, Jro, and $L_{2} K_{0}$ Mudge, Hanford Salt Cycle Process II. Engineering Development in a High Level Radiochemical Facility, HW-SA-3527, General Electric Company, Richland, Washington, August 17, 1964。

15. E。 M。 Levin, $C_{0}$ R。 Robbins and $H_{0} F$, McMurdie Phase Diagrams for Ceramists, The American Ceramic Society, Inc, $19 \overline{4}$ 。

16。 R。 L。Braun。 Unpublished data, General Electric Company, Richland, Washington。 1962, Personal communication, 
REFERENCES Continued

17. L。K. Mudge。 Unpublished data. General Electric Company, Richland, Washington. 1962 。

18. R. K. Willardson, J. W. Moody and H. L. Goering, The Electrical Properties of Uranium Oxides, BMI-1135. September 25, 1956.

19. J. L. Bates, C. A. Hinman, and To Kawada, Electrical Conductivity of UO 2 : Part Io Single Crystals, BNWL-296 Pt I. August, 1966.

20. $H_{0} J_{0}$ Anderson and R. Jo Anicetti. Specifications for High Density Uranium Dioxide (Nuclear Grade), HW-74204 REV I. September 9, 1963.

21. Ho J。 Anderson. Specifications for Nuclear Grade Mixed Oxides ( $\mathrm{UO}_{2}-\mathrm{PuO}_{2}$ ), Hanford Salt Cycle Compactible Powder, HW-84512-RD。 November 16, 1964.

22. C. E. Huck and O, H. Koski. Development of Salt Cycle Process Instrumentation, HW-74968. September 19, 1962。

23. G. R. Bloom. Detection and Oxidation Rate Studies of U(IV) in the Hanford Salt Crcle Process, BNWL-CC-373。 Pacific Northwest Laboratory, Richland, Washington。 April 26, 1966。

24. G. E。 Benedict, K. Mo Harmon, G. Jansen, Jro, L。 Ko Mudge, and F。 A。 Scott. Production of Reactor Fuel oxides from Molten Chloride Salt Solutions, HW-SA-2915。 General Electric Company, Richland, Washington, May 20, 1963.

25. Jo Jo Cadwell。 Quarterly Progress Report for January, February, March 1962, Fuel Development Operation, HW-72347。 General Electric Company, Richland, Washington。April 16, 1962。 (Classified)

26. Ro F。 Maness. Unpublished data。 General Electric Company, Richland, Washington. 1962. Personal communication.

27. W. Ho Yunker. "Chloride Contamination in Electrolytic UO 2 " Quarterly Progress Report, Research and Development Programs, Executed for the Division of Reactor Development, July, August, September 1963, HW-79280。 General Electric Company, Richland, Washington. October 1963.

28. Go E。 Benedict, $W_{0} R_{0}$ Bond, Go Jansen, Jr, L。 Go Morgan, and $J \circ R_{0}$ Lundquist. Status of the Salt Cycle Process for Processing Oxide Fuels, BNWLSA-205. Pacific Northwest Laboratory, Richland, Washington. September 3, 1965.

29. G. R. Bloom。 Melt Atmosphere Control Studies for the Hanford Salt Cycle Process, BNWL-CC-372。 Pacific Northwest Laboratory, Richland, Washington。 April 26, 1966。

30. Unpublished data. Chemical Separations Operation, General Electric Company, Richland, Washington. 196l。

31. P。 Do Miller, E. L. White, D。 Co Drennen, $C$ 。 $H$ 。 Lund, $H_{0} \mathrm{~J}$ 。 Wagner, A。 M。 Hall and $W_{0} K_{0}$ Boyd. Development of Container Materials for the Fused Chloride-Electrolytic Fuel-Recovery Process, BMI-1539. August 28, 1961.

32. W。 L。 Walker。 Unpublished data。 General Electric Company, Richland, Washington. 1962。 Laboratory notebook。 


\section{REFERENCES Continued}

33. J。H。Kleinpeter, Non-Metallic Material Studies for Molten Salt Processes, HW-72369. January 22, 1962。

34. Jo E。 Morrissey。 Preliminary Study on the Application of a Frozen Wall and Electrolytic Heating to Molten Salt Baths, HW-72572。 February 2, 1962 。

35. Do Co Brandt。 Alternating Current Heating of Molten Salts, HW-75468。 November 28,1962 。

36. L。 Ko Mudge and $J \circ R$, Lundquist, Chlorine Recovery and Radioiodine Behavior in the Salt Cycle Process, BNWL=279, July, 1966.

37. J。 J Cadwell。 Quarterly Progress Report for July, August, September 1960, Fuel Development Operation, HW-69085. General Electric Company, Richland, Washington. October 15, 1960。 (Classified)

38. Jo Jo Cadwell。 Quarterly Progress Report for April, May, June 1961, Fuel Development Operation, HW=70557。 General Electric Company, Richland, Washington。 July 15, 1961。 (Classified)

39. Jo Jo Cadwell。 Quarterly Progress Report for July, August, September 1961, Fuel Development Operation, HW-71422。 General Electric Company, Richland, Washington。 October 13,1961。 (Classified)

40. Jo Jo Cadwell。 Quarterly Progress Report for April, May June 1962, Fuel Development Operation, HW-74377。 General Electric Company, Richland, Washington, July 20,1962。(Classified) 


\section{Copy Number}

\section{Pacific Northwest Laboratory}

1

2

3

4

5

6

7

8

9

10

11

$12-31$

32

33

34

35

36

37

38

$39-41$

42

43

44
J. M. Atwood

G。 E. Benedict

A. G. Blasewitz

W. R。 Bond

R. E。 Burns

C. R。 Cooley

D. Ro deHalas

W. L. Delvin

K. Drumheller

W. Lo Hampson

K. Mo Harmon

G. Jansen, Jr。

B. M. Johnson

A. Mo Platt

W。 E。 Roake

R. C. Smith

J. Lo Swanson

E. E. Voiland

M. To Walling

Technical Information Files

Richland Operations Office

R. Ko Sharp

$\mathrm{C}$. I. Robinson

Isochem Inc

P. W。 Smith

OFFSITE DISTRIBUTION SPECIAL

45

W. A. Fmel

Idaho Nuclear Corporation

Idaho Falls, Idaho

46

Jo Schmets

(CEN)

Mol, Belgium

$47-51$

Division of Technical Information Extension 
